New Eyes on Curios:

\title{
The Acquisition and Repatriation of Toi moko between France and New Zealand as a Postcolonial Approach to Museum Practice.
}

by

Simon Jean

A thesis submitted to Victoria University of Wellington in fulfilment of the requirements for the degree of Doctor of Philosophy in Museum and Heritage Studies

Victoria University of Wellington 



\section{Table of Contents}

Acknowledgements...............................................................

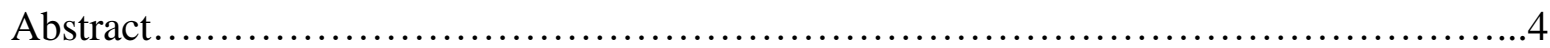

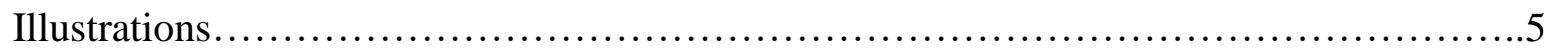

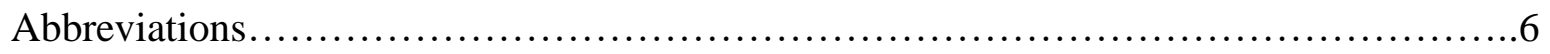

Prologue...............................................................

Introduction: Framing the context........................................... 11

Part I An assemblage of knowledge ignited by the repatriation process .................58

Chapter one First Encounters: the role of Toi moko in the colonial past of

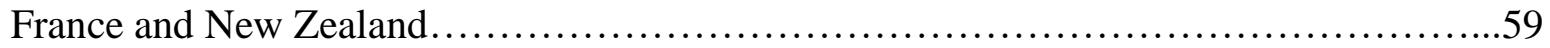

Chapter two From tūpuna to curios (and back again): The museum journey of Toi moko................................................................. 93

Part II Repatriation: From theory to a recognised museum practice....................119

Chapter three Kaitiakitanga and Mana Taonga: "Museums are guardians"...............120

Chapter four Museums in France: "Museums as a place of debate"’...............................156

Chapter five Repatriation as museum practice: "everything is going well as long as there is

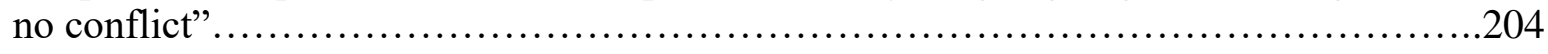

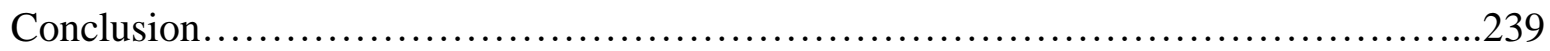

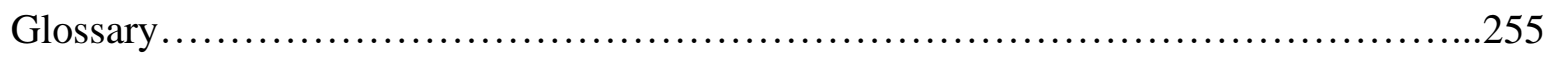

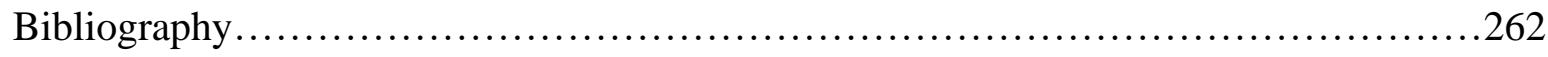




\section{Acknowledgements}

This journey to the completion of this thesis could not have been made without the team behind this effort. I could not do it without you. I would like to thank first and foremost all examiners that gave their time to evaluate this thesis and give me feedback.

To my primary supervisor, Conal McCarthy, I owe a considerable debt of gratitude since we met in 2010. His understanding of and contribution to museum studies has been a continual inspiration. I also thank my secondary supervisor, Peter Adds, who accompanied, encouraged, and guided me throughout the last three years.

I would like to thank Victoria University for trusting me to complete such a challenging academic project. This thesis would not have been possible without the enthusiastic participation of my colleagues from the Museum and Heritage Studies programme and their effort to help me understand every stage of this journey including my doubts. I am grateful for the support of Lindsay Bilodeau, Samuele de Stefani, Meg Mulder and their families for all the conversation shared at the office that help me to clarify my thoughts. And also thank you to Susette Goldsmith for reading and commenting on drafts of the thesis.

This thesis would also not have been possible without the enthusiastic participation of respondents who have been interviewed, in France: Sébastien Minchin, Catherine Morin Desailly, Michel Van Praët and Roger Boulay. And in New Zealand: Arapata Hakiwai, Puawai Cairns, Te Herekiekie Herewini and Coralie O’Hara.

During the course of this research project, the support of Te Papa teams and staff have been crucial. I would like to extend my deepest gratitude to KARP and its manager Te Herekiekie Herewini for giving me the opportunity to be part of the team and to understand as much as a foreigner can about mātauranga Māori. Te Arikirangi Māmaku and Mona Pauline Mangakāhia became good friends in whom I put my trust every time I came back to Aotearoa/New Zealand. I would like to thank National Services Te Paerangi, kaitiaki Māori, the mātauranga Māori team and kaumatua that came to Te Papa over the years: Shane James, Carolyn Roberts-Thompson, Chrissie Marianateoha Locke, Migoto Eria, Shane Pasene, Moana Parata, Hokimate Hardwood, Sonya Johnson, Herbee Hartley,

Te Kahureremoa Taumata, Megan Tamati, Suzanne Tamaki, Dougal Austin, Jade Kerry Hatfield, Jo Pleydell, Sean Mallon, Kylie Moana Ngaropo, Victoria Esson, Gavin 
Reedy, Mark Sykes, Martin Lewis, Dougal Austin, Teokotai Paitai, Shane Pasene, Norm Heke, Lisa Ward, Rangimoana Taylor, Matiu Baker, Florence Liger, Jacques Knudsen, Louisa Gommans, Marae Stone, Tom Ward, Mere Boynton, and Haly Hakaraia. I wanted to personally thank Rhonda Paku, Awhina Tamarapa and Hema Temara for their patience, their teaching methods regarding the transmission of tikanga Māori to a young French student and for their friendship. And off course, the entire Repatriation Advisory Panel team: Hokimoana Te Rika-Hekerangi, Te Kanawa Pitiroi, Derek Lardelli, Ngapare Hopa, Aroha Mead, Haami Piripi, Alfred Preece Junior and its chair Professor Pou Temara.

I would like to write few words regarding artists who wanted to help me get a bigger picture of contemporary art expression and tā moko practice: Hohua Mohi, Taryn Beri, James Webster and his whānau, Henare Brooking, Mark Kopua, Michel Tuffery and George Nuku. But also I need to acknowledge the taonga puoro practitioners such as Warren Warbrick and Brian Flintoff who gave me the chance to enjoy every note I played.

I would like to thank my friends in France and New Zealand who accompanied me throughout the completion of the $\mathrm{PhD}$. I acknowledge here the considerable debt I owe to Amber kiri Aranui and Nicola kiri Smith and their whānau. Every Sunday lunches, road trips and conversations helped me to understand what the stakes of such project are and more importantly, how a Frenchman can be involve in this international process of mutual understanding.

Last but not least, the patience and encouragement of my family is undoubtedly crucial, and their presence and support have been a driving force in my progress. For this I would first like to warmly thank my parents Agnès Jean (née Pigné) and Philippe Jean, without whom this project could not have been completed and to whom I dedicate this work. My sister, Noémie Clarke (née Jean), with whom I spent time talking about my English as a second language, and her husband, Richard Clarke, for our discussions on any New Zealand event. My brother, Antoine Jean and his wife Julie Jean (née Darcel), for their kindness, their compassion and their patience in delicate moments. At the same time, I wanted to send my warmest feelings to Cécile Clarke and her companion Jim for all shared moments and their hospitality.

And off course, I would like to send my deepest feelings to my wife Allix Jean-Nebbache for her daily support, and her trust that were essential in enabling me to complete this thesis.

Ngā mihi nui ki a koutou katoa. 


\begin{abstract}
This thesis is concerned with the repatriation of 21 Toi moko or ancestral Māori heads which were returned from France to Aotearoa New Zealand in recent years. The act of repatriation has been widely debated in the museum sector for decades and yet many institutions are still struggling to deal with the practical management of repatriation projects with indigenous peoples. The literature review revealed gaps in research particularly in relation to the current professional practice of repatriation. The questions framing the study include: Can the repatriation process be considered a postcolonial museum practice? How and why is repatriation practice related to the new inclusive museology, international dialogue and partnerships, and the acknowledgement of contemporary Indigenous identities in globalised museum networks?
\end{abstract}

This research employed a mix of qualitative methods to investigate this topic. In order to explore the acquisition and collection of human remains, archival sources were used to better understand the historical context of the trade and their subsequent donation to museums and scientific institutions in France. Semi structured interviews were conducted in both countries to investigate the current practice and assess the impact on French practitioners of the interaction with Māori and New Zealand museum staff and iwi. Case study methodology was used for analysing the data gathered during fieldwork in France and New Zealand. My personal involvement in the process, from initial negotiations to repatriation ceremonies and various post repatriation projects, led me to apply action research and participant observation. As a non-Māori researcher analysing this sensitive topic, I was also guided by Kaupapa Māori theory.

The findings of the research reveal the varied range of reactions, assumptions, debates, fears and lessons expressed by museum staff, academics, politicians and others as a result of repatriation projects. I argued that these interactions were a form of contact zone which created mutual understanding and ongoing relationships. The thesis has identified key themes that encompass a global, diplomatic approach to repatriation as an integral part of postcolonial museum practice: the evolution of appropriate names for human remains, repatriation from theory into practice, strategies of interaction, methods of (re)connection, recognition of the ethics and dignity of human remains and finally cultural diplomacy. 


\section{Illustrations}

\section{Photographs:}

Figure 1

Figure 2

Figure 3

Figure 4

Figure 5

Figure 6

Figure 7

Figure 8

Figure 9

Figure 10

\section{List of maps:}

Map 1

Map 2

Map 3
Acquisition book of Museum of Rouen

Karanga Aotearoa Repatriation Programme staff in 2009

Waitetoko marae

Rhonda Paku during her kōrero

Te Herekiekie Herewini presenting KARP principles

Pūtātara and pūkāea

Haka pōwhiri

Tangata whenua and manuhiri at Rongomaraeroa

Whaikōrero by Te Kanawa Pitiroi

Hongi at end of ceremony

\section{List of Tables:}

Table 1

Table 2

Table 3

Table 4

Table 5

Table 6
Paris divided into 20 arrondissements

The eighth arrondissement of Paris and the locality of the rue de Mornie

French cities that returned Toi moko
Explorations that acquired Toi moko

Iwi exhibition presented at Te Papa since its creation

Hui ā rohe organised by the KARP

List of post- repatriation projects in France since 2011

List of French cities and institutions that returned Toi moko

Naming and categorisation of Toi moko through the years 


\section{Abbreviations}

CDP

CEO

DRAC

ICOM

KARP

MAAOA

MAA

MNHN

MQB-JC

NSTP

OCIM

RAP

Te Papa

Treaty
Code du Patrimoine (Heritage Code)

Chief Executive Officer

Direction Régionale des Activités Culturelles

International Council of Museums

Karanga Aotearoa Repatriation Programme

Musée des Arts Africains, Océaniens, Amérindiens

Museum of Archaeology and Anthropology at Cambridge

Musée National d'Histoire Naturelle (Paris)

Musée du quai Branly-Jacques Chirac

National Services Te Paerangi

Observation Coopération Informations Muséales

Repatriation Advisory Panel

Museum of New Zealand Te Papa Tongarewa

Treaty of Waitangi, 1840 
Le seul véritable voyage, le seul bain de Jouvence, ce ne serait pas d'aller vers de nouveaux paysages, mais d'avoir d'autres yeux, de voir l'univers avec les yeux d'un autre, de cent autres, de voir les cent univers que chacun d'eux voit, que chacun d'eux est. / The only true voyage, the only bath of Youth, would be not to seek new lands but to possess other eyes, to see the universe through the eyes of another, of a hundred others, to see the hundred universes that each of them sees, that each of them is.

Marcel Proust, 1923, Remembrance of Things Past,

'La prisonnière', 5th Volume, 69. 


\section{Prologue}

Since I read this last section of his famous Remembrance of Things Past, French writer Marcel Proust (1871-1922) has framed my attitude towards the repatriation debates explored in this thesis. Today, we consider the world from different angles, including museums and the objects in their collections. Through globalisation and modern ways of recording and communicating information, people are closer than ever. That is why debates on repatriation encompass people from different backgrounds, different experiences and, thus, different perspectives. Because of the imbalance of power caused by colonisation, analysis of the repatriation process brings out different views and perspectives on museums, collections, and communities, and opens a dialogue with living communities of origin that has the potential to reshape museum practice. It is important to recognise that, as scholars of museum repatriation have pointed out, "repatriation is not only about the loss of objects for museums but can be about important gains in terms of cultural relationships and knowledge" (Thythacott and Arvanitis 2014, 8).

This study explores French engagement in the practice of the repatriation of Toi moko (preserved Māori heads) to Aotearoa New Zealand. In examining this process of return, I acknowledge the innovative approaches made by museums in rethinking their intercultural relationships with source communities along with concepts such as collecting and ownership. Repatriation is seen in this thesis as an opportunity to initiate collaboration between French museums and the Museum of New Zealand Te Papa Tongarewa (Te Papa). Moving beyond theoretical critique, I examine the strategic interactions revealed by the repatriation process in a postcolonial context. This research also focuses on the outcomes engendered by connections between museums and Indigenous people.

Throughout this thesis, I choose to refer to preserved Māori heads by their name in te reo Māori: Toi moko. Toi moko was the name used by the late Māui Pōmare in the 1980s (Aranui 2018). He was chair of the National Museum's council and he laid the foundations for the current repatriation process in New Zealand. The term is used also by the Karanga Aotearoa Repatriation Programme (KARP), and I decided to follow this choice of terminology. The use of the term is important here in order to avoid references to differences of status, family 
heritage or iwi history. Toi moko is defined as all the ancestral heads prepared under the same customary drying process called pakipaki māhunga. I use the capital T for Toi moko in every chapter of the thesis because Māui Pōmare wrote it this way in his research, and my choice is an acknowledgement of his accomplishment and his influence on research about te ao Māori (the Māori world). Because the repatriation process examined in this thesis is only concerned with Toi moko formerly stored in French museums I focus essentially on those human remains and no other skeletal parts of tūpuna (ancestors) which are preserved in French collections.

This thesis considers the case of Toi moko obtained by French public institutions, their changing meanings in the museum environment, and the different repatriation practices which have facilitated their return from France to New Zealand. French perspectives concerning these heads are multiple and changing. Considered variously as curiosities, specimens of natural science, ethnographic artefacts or even artforms, the evolution of meanings and the changing status of these heads within museum collections illustrate ambiguous French attitudes regarding the collecting of human remains in general and have recently led to a precise new definition of the role of the museum in relation to ethnographic objects and human remains (Patin and Jean 2010; Salmond and Thomas 2010; Patin 2013, Kreps 2003, 2006). France, as a former Western colonial power with its global empire, enriched its museum collections through various voyages of exploration and colonial settlements around the world. Today, international consensus on museum practice recognises an increasing interest in reclaiming those items by descendent source communities (Kreps 2003; Thythacott and Arvanitis 2014; McCarthy 2007; Thomas 2016). With this process of repatriation of Toi moko to New Zealand, we focus our attention on collection 'items' which have two contentious dimensions according to the French perspective; they are human remains and they were acquired during the colonial period. 


\section{Introduction:}

\section{Framing the context}

Because of the remarkable beauty of Māori facial tattooing noticed by Joseph Banks on the Endeavour's first expedition to Aotearoa New Zealand by James Cook, undertaken between 1768 and 1771 (Beaglehole 1962), there was, subsequently, strong interest, shown by European colonial empires in obtaining heads. It was also during Cook's circumnavigation that the first acquisition was mentioned in writings by European explorers. The ship's naturalist Joseph Banks acquired a Toi moko in Queen Charlotte Sound on January 20, 1770. A young boy of 14 of 15 had been killed and his head was the one acquired by Joseph Banks (Banks, 1768-1771). In 1831, the New South Wales governor banned this trade in Sydney and imposed a fine of $£ 40$ on ships’ members who acquired Māori dried heads (Aranui 2011, 1). The current demand for the return of Māori ancestral remains is a relatively new one for France, in that the claims involve not just one museum and one example of known human remains but all the Toi moko stored in French public collections. Even if we are not talking about hundreds of heads, it is still the first time that France has had to face a claim of repatriation for human remains involving several museums across France.

In 2007 we saw the first approach which was from one French museum, the Muséum d'Histoire Naturelle de Rouen, located in the city of Rouen, capital of Normandy, to the Karanga Aotearoa Repatriation Programme (KARP) in New Zealand. From this point, the issue of the repatriation of Māori ancestral remains from French public collections was elevated to a national scale. Because France had undertaken only one repatriation of human remains before the return of this particular Toi moko, the debate regarding the repatriation of several Māori ancestors was complex and multi-dimensional on both cultural and legal levels. French people wondered: why do we have to repatriate these 'objects' from the national collection in France? Do we necessarily have to respond positively to all requests? What will become of the objects after the repatriation? How can we define and distinguish, legally, human remains from other collection items?

Unfortunately, this return could not go ahead because the French Ministry of Culture opposed it, a move that highlights the characteristics of inalienability and imprescriptibility to which the Natural History Museum of Rouen had to refer due to its status as a Musée de 
France. According to the law, established on 4 July 2002, artefacts in collections under the label 'Musée de France' must be evaluated by a committee before the can be deaccessioned and removed from the collections. The decision by the Ministry of Culture confirmed the stance that, in France, human remains were predominantly viewed from a Western curatorial and scientific perspective. Considered as research material for increasing knowledge about humankind in general, those human remains, therefore, had progressively lost their genealogical affiliations with living communities. They were held to be like any other object within the museum collections and were stored under preservation conditions indistinguishable from other anthropological items (Cornu 2009; Cadot 2007, 2009; Fontanieu 2014).

Before the Toi moko example, France had decommissioned two human bodies from two Parisian museums, in 2002, in order to repatriate them to their communities of origin. The Musée de l'Homme returned the body of Saartje Baartman to South Africa and the Muséum National d'Histoire Naturelle (MNHN) agreed to repatriate the human remains of Vaimaca Peru to Paraguay.

The case of Saartje Baartman, widely known as 'the Hottentot Venus' (Bancel et al 2004; Cadot 2007; Patin and Jean 2010; French Press release 2013), was presented in 2007 as an example to follow for the Toi moko. The French Government had agreed to this particular request in order to let Saartje Baartman have a proper funeral ceremony after her life of slavery and prostitution in Europe, including England, Holland and France, and following the dissection of her body by Georges Cuvier in the MNHN in Paris. In July 1994, during a visit to South Africa by François Mitterrand (the French president at that time), the South African government requested the return of Saartje Baartman's body through an official appeal made by Nelson Mandela. France declined this request, stating that the ancestral remains were state property (Blanchard et al 2011, 46). After the repatriation of Saartje Baartman's body to South Africa, some researchers and curators were afraid that they would receive too many requests from communities from all around the world to return other human remains. Up until the repatriation of Toi moko nine years later, it appears that the idea of opening French museum collections to possible repatriation was regarded as a mistake. The repatriation of Toi moko illustrates France's attempt to restore the balance spiritually, ethically, and also politically between colonisers and colonised. The long process of negotiation embodied the struggle of the French government to deal with its colonial past. Even though these Māori ancestors did not live or die in France, unlike Saartje Baartman, this 
repatriation issue prompted a debate concerning the abundance of human remains in French collections, the conditions under which they were acquired, their scientific uses and future possible repatriation demands.

With Toi moko, France had to face these high stakes and to define more precisely the role of Toi moko in museum collections. Professionals and politicians (curators, senators, researchers) involved in the proceedings quickly realised there was a lack of knowledge about the historical background of these collections. Furthermore, the reasons why Māori communities wanted to have these human remains returned was not well understood but remained very important.

The motivations of French media and politics are part of broader ethical and ontological debates on this topic (International Symposium 2008; Morin Desailly 2011; Varea et al 2011). They include arguments, on one hand, about the origin of the remains and the respect due to them and, on the other hand, analysis of the context of acquisitions research. Because Toi moko were obtained in the not-so-distant past and, moreover, as part of a deliberate colonial scheme to settle the South Pacific, negotiations for the return should have included more consideration of these points. Attempts to discuss the situation were hampered by a lack of knowledge about the history of these human remains, how they were acquired by French institutions, or the general attitude of Māori people today in regard to these mummified ancestors. This thesis offers not only a clarification of the historical background to the trade but also a critical observation of, and engagement in, the current repatriation process, in both France and New Zealand.

There is a major gap in the literature of museum studies, as seen in the review below, about repatriation protocols, how they are negotiated on a practical level, and how consideration of this development in professional practice aids understanding, comprehension, and interaction between museum and communities of origin (O’Hara 2012; McCarthy 2011; Pickering 2015; Aranui 2018). As I show in this thesis, my involvement in the repatriation negotiations between KARP and the museum of Rouen led to new understanding of museums as a place where this negotiation takes place. Therefore, I assert that repatriation is an integral part of museum practice and not just a political controversy over the ownership of cultural property (Peers 2017). 


\section{Background}

The study of theses restitutions from France to New Zealand requires us to consider the heritage value of human remains in different contexts. Even if their appreciation may have changed on French soil, their understanding within Māori communities is still the same. Several themes or values of the Māori community are reflected in this situation and make up the heritage value attributed by Māori to these ancestors (Karanga Aotearoa 2009). This can be seen clearly in the framework of the official government-funded repatriation unit KARP at Te Papa, set up in 2003, as follows:

The New Zealand Government has stated six principles for the Karanga Aotearoa Repatriation Programme.

- The government role is mainly one of facilitation-It does not claim ownership of kōiwi tangata.

- Repatriation is by mutual agreement only.

- The programme does not cover Māori remains in war graves.

- Kōiwi tangata must be identified as originating from New Zealand or the Chatham Islands.

- Māori and Moriori are able to be involved in the repatriation of kōiwi tangata and to determine the final resting places.

- No payment will be made for kōiwi tangata.

These principles convey the role of the New Zealand Government and Te Papa in regard to repatriation work. (Karanga Aotearoa Repatriation Programme, 2010a)

This research also concerns my own personal journey as a French man learning about Māori culture. After receiving the opportunity to become the first foreign intern at KARP, I pursued my own interest in Māori tikanga and gradually learned more about Māori language and cultural heritage. I was 21 years old when I came to New Zealand for the first time in 2009. I felt it was very important to work alongside KARP and understand the methodology by which the programme is initiated and undertaken. This process of becoming involved personally with KARP was, in my opinion, the key turning point in my own journey learning 
about repatriation. With this opportunity I had the chance to increase my awareness and my insight and understanding of the challenges, but also the subjectivity and potential bias necessarily involved. I also try to take into account these issues in the establishment of my methodology.

It seemed to me at the time that the repatriation process itself, and the extensive interaction with Māori people, helped the French government to clarify the circumstances and grant proper legal status to the human remains still in museum collections and, furthermore, led to changes in museum practice. This research explores this proposition in more depth and from different angles using a range of sources, as explained in the research design below. The negotiations around the repatriation of Toi moko by the Museum of Rouen highlight a paradox concerning the legal status of human remains in public collections and more particularly in the collections of Musées de France. According to the Civil Code and article 16-1, the human body cannot be subject to heritage rights, supported by the "Bioethics law" (law n94-654, 29 July 1994) and, conversely, according to the Code of Heritage, the collections of Musées de France are imprescriptible (that is, they cannot rightfully be taken away, lost, or revoked; they are inviolable) and inalienable (incapable of being alienated, surrendered, or transferred). In order to respond to the demand for repatriation, French authorities had to consider museum policies regarding human remains and their inalienable legal character as collections.

Even if the legal status of human remains, and thus Toi moko, in French collections seems to be an important part of the debate and representative of the controversy around Toi moko, it is not the central topic of this thesis. This changing law is a topic for another study and several researchers have already examined the matter (Cadot 2007, 2009; Cornu 2006, 2009; Fontanieu 2014). However, the French parliament has already created some rules that every repatriation request must adhere to:

(1) The request must be formulated by a legitimate entity, i.e a democratic country; (2) The request must be made by the intermediary of a living community; (3) In order to be sent back to their rightful owners, the human remains must be part of the cultural patrimony of those communities; (4) It has to be proven highly important for such items to go back home (for reburial, for example); (5) The restitution process has to be based on respect 
for human dignity, cultures, and beliefs. (Charlier 2014, 293, my

translation)

Fontanieu argues:

The concept of human dignity provides some answers, often bold, sometimes ambiguous. Since 1994, the normative framework of human dignity has been strengthened to achieve in 2008 the insertion of a 16-1-1 article in the Civil Code prescribing the treatment with respect, dignity and decency of the remains of deceased persons. By adopting such a provision, museums specializing in exhibitions of human remains, such as Dupuytren or Fragonard, may find themselves weakened in their action. (Fontanieu 2014)

On 9 May 2011, the first repatriation ceremony was held in the city hall of Rouen, Normandy. On that occasion, the city's natural history museum, the Natural History Museum of Rouen (NHMR), repatriated the only Toi moko preserved in its collection. Then, on 23 January 2012, the Musée du quai Branly-Jacques Chirac (MQB-JC) in Paris held another ceremony, gathering not only the seven Māori heads in its collections but also 13 others which were stored in nine institutions across the country. These institutions were of different kinds. Six heads were stored in three different natural history museums (four in Paris, one in Nantes and one in Lille), one was in the National Maritime Museum in Paris; Another one was kept in the Fine Arts Museum at Dunkerque; ten were located in three museums considered ethnographic (seven at the MQB-JC, two at the Musée des Confluences in Lyon and one in the Musée d'Arts Africains, Océaniens et Amérindiens in Marseille (MAAOA); one Toi moko was part of the collection of the municipal museum of the city of Sens, and, finally, one was kept in a museum but in a university collection, more specifically in the Anatomy Conservatory of the Medical School of Montpellier.

Given this background to the recent repatriation of human remains from France to New Zealand, I wondered whether the main focus of this thesis would be whether or not French museums had started to rethink their approach to their 'ethnographic' collections of Māori origin following the repatriation request and subsequent events. The system of knowledge that founded museum practice in France is based on Western concepts such as the universalist dimension of museum collections and is deeply rooted in conventional European models of museology (Kreps 2006). I wondered: Could the current rethinking of and changes in French 
museum practice have resulted from an increasing exposure to repatriation practice and to contacts with communities of origin? During negotiation between 2007 and 2011, KARP played a role by establishing dialogue with French museums on the model of biculturalism that characterised the administration of Te Papa. As a result of the contact made in respect to their Toi moko, museums in France rethought the traditional role of museums based on their creation during the colonial period and became more interested in the notion of contemporary 'Indigeneity', as seen in discussions regarding contemporary Māori communities (International Symposium 2008). As a result of the revised ICOM code of ethics and past repatriations from different countries, it seems that French museums wanted to refine their policies and ethics in line with this emerging international practice. So, because of the repatriation exchanges between France and New Zealand, strong debates about the social and ethical responsibilities that museums undertake in museum society, debates which are reflected in the wider literature on this topic (Besterman 2006).

Repatriation was understood here as an opportunity to define more precisely the status of this collection (legally or morally), therefore, this dialogue brought about more than a temporary commemoration during the repatriation ceremony but actually enabled the development of knowledge about Māori 'ethnographic' collections. From the French perspective, the request for repatriation can be analysed and completed if the request is made by the source community. Because the information gathered initially was not sufficient, French professionals involved in the repatriation had to find out more about repatriation policies in New Zealand (Ministry of Culture and Heritage Te Manatū Taonga 2004; McCarthy 2011; Fforde 2002). I gained my experience in New Zealand in this field as an intern first, then observer and finally contracted researcher within the KARP team from 2009 until today. Many of the comments or opinions expressed here are uniquely mine and based on my experiences, and may not reflect the views of Te Papa, or any other museums or public institutions involved. It took three years (2007-2010) for the French government to gather enough information to write up and vote for the legal proposal, and four years passed between the failed ceremony and the actual return of the first Toi moko in 2011, both held in the city hall of Rouen. Because the repatriation request emerged in France in a typically administrative way (Pickering 2015), the French government responded slowly to repatriation issues compared to other colonial Western countries.

In 2008, while I was completing my bachelor's degree in history at the University of Rouen, I had the opportunity to meet the director of the Museum of Rouen and convinced him to 
entrust me with this research project to gather information necessary for the creation of future draft laws on Toi moko repatriation. Added to this, various negotiations were necessary with the manager of the repatriation programme in New Zealand to convince him to accept my internship. With this latter agreement, I was able to learn more about repatriation policy in New Zealand and tikanga Māori. This Te Papa programme had never worked with a foreign intern before. The collaboration also provided an opportunity to enhance relations between the New Zealand programme and French institutions.

Between April and June 2009, my first intervention as part of the work was to try and make the French authorities involved understand the commitments and motivations of the programme seeking the return of ancestral remains to their homeland. I also contributed to the process of writing the new proposed law established by Catherine Morin-Desailly, senator of Seine Maritime (department of Normandy). On 29 June 2009, the Senate voted unanimously in favour of restitution. This was the first decision taken by Frédéric Mitterrand as Minister of Culture. With the passing of law n²010-501, on 18 May 2010, French museums or public institutions could now officially repatriate Māori human remains to their communities of origin. However, the law only applied to Toi moko and not to kōiwi tangata (human bones). Thus, as a result of this process of negotiation over repatriation, there appeared to be a rethinking of the notion of heritage within the museum policies implemented in the management of French anthropological collections. Since then, my research has centred on and explored the dialogue that has developed as a consequence of the return of human remains among French and Māori in order to trace the ways in which the process has influenced attitudes, values and professional museum practice.

Two criteria are essential for French authorities to attend to repatriation negotiations; the support of the government of the country where the Indigenous community is located; and adequate logistics and organisation to return the human remains. Even if we raise questions about who can provide these constitutional norms, the French government was aware of the support of the New Zealand government through its funding of KARP. As a result of my internship, I was able to appreciate the significance of tino rangatiratanga (selfdetermination) as articulated in the Treaty of Waitangi in this professional environment, expressed through the role of Te Papa and the desire of the Māori community to control decisions concerning their own cultural heritage. Inspired by this experience, the current research aims to explore how cultural organisations can be shaped by kaupapa Māori research, that is, research by, with, and for Māori communities (Smith 2012). My position as a 
European student investigating Indigenous topics is also framed by this methodology, requiring sensitivity and respect on my part. Moreover, my focus on Māori culture in museums and its transformative potential for museology is in line with the new tendency in European museums to include the perspectives of source communities (Peers and Brown 2003; Schorch and McCarthy 2018) within their museum practice.

\section{Research Questions}

Many human remains which are preserved in French museums and were collected during the colonial period have not been identified. Their names, as they were understood at the time of their European acquisition, have been lost. The way in which the process of repatriation has been followed by France and New Zealand gave an opportunity not only to think about the role of these remains in the museums but also to restore their initial significance for Māori. The procedure also provided different opportunities for French museums to acknowledge te ao Māori as it is seen and valued today by Māori themselves.

My research will seek the answers to the following questions: Can the repatriation process be considered a postcolonial museum practice? How and why is repatriation practice related to the new inclusive museology, international dialogue and partnerships, and the acknowledgement of contemporary Indigenous identities in globalised museum networks? What has been the impact of the repatriation policy on the relationship between Māori communities and French museums?

\section{Research Aims and Objectives}

The main objective of this thesis is to study the effects and impacts of the process of repatriation as it was engaged in by France and New Zealand. In doing so, the research has to examine the debates and choices made during the process between the two parties in order to return Māori ancestral remains. Choices determined the importance given to such a process of return in terms of museology, politics, cultural relationships, and scientific fields.

Consequently, the research will provide information about the process chosen by authorities in order to return the 21 Toi moko despite a certain lack of experience or knowledge in the first stage of the negotiation. It was only after the first stages of negotiation between the Museum of Rouen and KARP that Māori heads became known to the public in France. Yet these heads were in French museum collections for over a century. Regarded as curiosities at the time of acquisition, they became objects for which the information was non-existent or inaccurate. Therefore, an important objective of this thesis is to explain how the Toi moko 
came to be acquired by French institutions in the first place, as understanding this historical context seems to have been essential in facilitating the contemporary practice of repatriation.

This thesis, the first undertaken by a French researcher in collaboration with KARP and Victoria University of Wellington, attempts to critically analyse the issues which emerged from the policy and practice of repatriation in museums, and thereby enhance our understanding of this unique type of 'cultural property'. This research also aims to study the role of Toi moko in the representation of Māori collective identity and the motivations that have driven these requests for repatriation. It seeks to investigate how Toi moko act as elements of Indigenous intellectual property and tries to explain the consequences of the repatriation of these Toi moko and how this has fostered the construction of Indigenous cultural identity today. This research seeks to increase the knowledge of French professionals in museums about Māori values, as was mentioned in the research carried out in Rouen, Paris and Montpellier between 2011 and 2016. It is not a matter of questioning the stakes in which this operation plays a role but simply testifies to the approach carried out by the programme. It is not, however, simply a matter of presenting the results of the research data obtained during the repatriation ceremonies. The individuals who participated in this study are mainly sensitive actors in terms of these returns of their ancestors. Because of the participatory nature of my fieldwork at Te Papa, the informants are mainly museum professionals, which leads me to think that the speeches and other data collected are oriented according to the museums' activities.

This thesis is also focused on the challenge that a repatriation request invokes for French museum practice. Because of the lack of information around Toi moko before the official request, and the conflict and rivalry between some museums and professionals it engendered, it is important to acknowledge these issues were hotly debated and controversial, which created challenges for me as a go-between working on both sides of the process.

Understanding the initial French fears and concerns regarding this specific demand helps us to appreciate how their attitudes changed over time, so that a museological form of 'cultural pluralism' came to be practised within general ethnographic collections. In the following chapters I try to summarise this by highlighting two different examples of museum projects in 
which Māori perspectives were included, the permanent exhibition in Rouen and the reception of a temporary exhibition at MQB-JC.

Researching this sensitive topic has been difficult because it has been hard to get people to articulate any negative views re repatriation. I was able to get some statements questioning this international process but was not able to get professionals to talk openly about the value of scientifically-recognised data versus repatriation claims. This was one of the most difficult positions to explore, partly because of tensions about the topic and my reputation as someone who was working as a 'spy' either for the French or for Māori. Because the sensitivities about KARP or the repatriation process are quite personal, it was hard to consider all the statements. At this stage of the introduction it seems important to point out that this research did not set out to answer all the possible questions concerning repatriation but focused on investigating particularly the issues emanating from the French actors within the process.

\section{Literature Review}

I want to introduce my literature review by highlighting the multicultural and multidisciplinary approach taken to this research topic which builds on interdisciplinary theories and methods from museum studies, ethnography and related fields. Due to my professional involvement within museums, my research is centred on museum studies and practice, but it also draws on the related disciplines of history, anthropology and Māori studies. These four disciplines provide essential insights to the understanding of the repatriation of Māori human remains, and I plan to complete this research by drawing on literature in these four areas.

Even though this thesis is interdisciplinary, it is principally conducted within the framework of museum and heritage studies. This field focuses on the history and evolution of museums through time, their politics, policies and processes involved in their management, but also their societal role analysed in a specific period of time from their inception to the current day (Hakiwai 2014; Macdonald 2006). Museum studies also focuses on the professional practices that make up a museum, such as collections, exhibitions, curation and education, but includes recent attention to community engagement such as relationships with source communities through issues such as repatriation (Thythacott and Arvanitis 2014; Kreps 2003; Crooke 2008; McCarthy 2011, 2015; Aranui 2018). That is the reason why museum studies can also be defined as the analysis of the museum and its sociological, political and cultural function/role in the society where/when it is located (Macdonald 1996, 5). The field where I have been conducting this research is the museum environment, whether in France or New Zealand. The 
'anthropological' and ethnographic dimensions of this study arise from the ways those human remains are understood according to historical French sources, in contrast to their genealogical roots linked to the living source community of Aotearoa as perceived by Māori.

Finally, in order to describe Toi moko and the tangible and intangible heritage they embody, it is important to conduct this research through the lens of kaupapa Māori theory and methodology which enables meaningful and ethical engagement with the culture enveloping those tūpuna and their descendent source communities. Altogether, balancing Indigenous and Western frameworks can help us to understand the complex issues about the repatriation of human remains and allow me to address the following research question: How can the repatriation process be considered a postmodern museum practice?

\section{Museums and source communities}

The topic of repatriation can be thought of as a consequence of the rethinking of the museum's role in relation to other cultures. It is generally said that museums are constantly evolving in order to reflect challenges met by societies. James Clifford's well-known expression, inspired by Mary Louise Pratt, clearly articulates this tendency:

When museums are seen as contact zones, their organizing structure as a collection becomes an ongoing historical, political, moral relationship - a power-charged set of exchanges of push and pull. (Clifford 1997, 192)

What Clifford develops here could be applied to this research through the notions of relationships and contact zones. Repatriation is considered in this thesis as a way to open the discussion between museums and source communities. This is the reason why museums are consequently regarded as public institutions where such encounters can take place. By analysing the repatriation process, discussions on the return of Māori ancestors instigated discussions and questioning in France and in New Zealand. France has a long colonial past and New Zealand is a relatively young country where the source community has substantial influence. Because repatriation is focusing our attention on human remains preserved in French collections, museums could be seen as sites of encounter between French and Māori. A museum is thus seen as a 'contact zone', not just a peaceful or 'dead institution' but also a place of debates where exchanges and experiences can be shared. The repatriation process embodies this aspect of the role of the museum in modern society. It has generated contacts and debates between French museums, French and New Zealand institutions and between Māori. And those connections create a network which is necessary in order to understand each 
point of view regarding Māori ancestors. Scholars of museum studies argue that engagement with source communities has transformed professional practice:

These changes have been given impetus by new forms of research and relationships which involve the sharing of knowledge and power to meet the needs of both parties. This new approach to research, which also informs curation and display, involves museums and community members working towards building a relationship of trust, often in cases where none has existed before and where there may be a significant legacy of distrust as a result of the dynamics of earlier anthropological and museum research projects. The desire and processes used to build such trust and to share power are the most important manifestations of a new curatorial praxis which incorporates source community needs and perspectives. (Peers and Brown 2003, 1-2)

This study examining the French repatriation of Toi moko is also an opportunity to consider another perspectives held by French museums; repatriation also involves a new approach to managing contemporary relationships, using the museum as a medium of communication.

It is no longer sufficient to treat indigenous objects as inert relics or bits of art to be arranged according to abstract typologies in standardized storage facilities. Taking account of indigenous practices and interest serves to decentre the dominance of scientifically based museology by making us aware of the assumptions and values inherent in western practice. (Kreps $1998,8)$

In current curatorial practice and museology, the approach towards objects seems to have changed, it is no longer simply a reflection of historical material which proves the relationship between the museum and the group that is represented. Nicholas Thomas says that he "cannot think of a modern human community not shaped by histories of interaction and movement" (Thomas 2016, 14). Through the repatriation negotiation, France and New Zealand created a modern cross-cultural exchange. In this thesis I will highlight the effect of this return of ancestors on the globalunderstanding of the French involvement in the Toi moko traffic and more generally in the colonial history of New Zealand. Thanks to the research undertaken in order to learn more about the Toi moko, I have at my disposal a lot of material which throws light on the changing nature of relationships between these two countries, from the first 
encounters to the post-repatriation period. Nicholas Thomas inspired me not only through his research but also through his professional practice as professor of anthropology and museum director/curator. Since he became the director of the Museum of Archaeology and Anthropology at Cambridge (MAA) in 2006, Thomas has taken a new approach to museum research in engaging contemporary artists and communities. The exhibition Pasifika Styles in 2006 and the project 'Artefacts of Encounter' between 2010 and 2013, are projects in which the source communities have played key roles.

They [collections of MAA] took as a starting point the proposition that, while artforms and objects have conventionally been seen to encode or reflect meanings, they are not simply symbolic. Rather, they can be seen also as material makers of relationships: they can express transactions and transformations. They can be especially revelatory in cross-cultural settings, notably as gifts intended to turn a mere encounter into a positive relationship, for instance (Thomas et al 2016, 19)

Along with this idea of objects making and remaking relationships, repatriation can also be seen as a way to demonstrate the strong revitalisation of Māori cultural identity and show people how Māori regard their ancestors. For too many years, museums ignored the different perspectives of the source communities. As Kreps argues: "[Into the Western system of knowledge] non-Western objects have been systematically organised and reconfigured to fit into Western constructs of art, culture, history and heritage" (Kreps 2006, 459). The influence of Kreps in this research framework is consequently reflected in post-colonial theory in relation to Western and non-Western perspectives on questions regarding the museum's role or the roles of professional staff such as curators. Kreps argues that "As these communities [that is, non-Western, Indigenous, native peoples] have increasingly begun to demand a greater voice in how their cultures are presented in museums, they have also challenged conventional, museological paradigms of cultural representation of preservation" (Kreps 2003, 2).

Before 2007, French museums did not have much contact with Māori groups. In this context, KARP could be considered an ambassador of Māori identity. For example, French museums no longer defined Māori collections as just artforms or artefacts but started to call them taonga, and defined what taonga means from a Māori perspective. Two main initial actions that reflect this change in French collections are: the creation of a permanent exhibition of the 
Oceania collections at Rouen after 2011 and the reception of the exhibition E tu Ake: Mãori standing strong shown at MQB-JC in Paris, between October 2012 and January 2013 (Gagné, Roustan 2014; Crenn, Davidson, Gagné and Roustan 2014; Smith 2011; Jean 2013).

Here, we can see the result of how some museums or research groups seized upon this conflict around human remains as an occasion to interact with Indigenous communities and redefine their relationships with groups of origin (Tapsell 2002, 2011; Thomas 1991, 2016). Moreover, during this period there was another repatriation between France and New Zealand but this was of taonga tuku iho and not human remains. Stored for 60 years in the New Zealand Embassy in Paris, the poupou Tìtokowaru returned to his iwi, Ngā Ruahine from Taranaki. Even though it is not from French museums but the New Zealand territorial entity in France (Horwood 2014), the return of this taonga was further confirmation of this new collaboration. This implication of Indigenous voices or "shared expertise" (Roustan 2016, 160) in French museums' activities, such as curation, exhibition and communication, also highlighted several issues in the process for each of the museums involved.

The question of shared expertise is at the heart of the issues. It calls for a reflection on the logic of production and sharing of knowledge at the museum and the validity of the domination of science relative to other approaches. The plurality of interpretations is made at the risk of openness, on the one hand, to different ontologies, even competing, Western naturalism (Descola 2005) founder of scientific and heritage institutions and, on the other hand, to uses of museum likely to question the values which are at the beginning of his vision of the collections, in the first rank of which the physical preservation and the moral inalienability. (Roustan 2016, 160.)

Even though museums exist in both France and New Zealand, the links between collections in museums and their source communities are not similar. Reflecting the colonial and colonised pasts of each country, the museum paradigms are consequently disparate. Because Māori are the Indigenous people of New Zealand, the Indigenous role in museums was expanded after the 1980s. The input of the Te Mãori exhibition on current bicultural policies, by including Māori cultural practices and spiritual beliefs, has transformed museums today into repositories or places where treasures can be stored in suitable conditions according to both their spiritual and scientific values. Museums are not only places where treasures are 
exhibited but also institutions where source communities can have a role to play in terms of curatorial conditions and communications around taonga during the period when their treasures are stored there (Tapsell 2002, 2011; Peers and Brown 2003; Butts 2003; Kreps 2011; Hakiwai 2014; Horwood 2015; McCarthy 1997, 2007, 2011, 2018). The role of kaitiaki (guardians) became one of the foundations of the bicultural system within museums in New Zealand (McCarthy 2011; Schubert-McArthur 2014). Curators are not the legal owners of the Māori collections and the role of kaitiaki regarding taonga, as explained by Conal McCarthy (2011), embodies this new approach of museum professionals' activities:

Furthermore, kaitiaki Māori have a unique taonga-centred vision and see their guardianship role as relating to the spiritual and intellectual dimensions of taonga and not simply their physical aspects. Māori professionals see themselves contributing towards iwi development, and this means they have different perspectives, training requirements and work conditions (McCarthy 2011, 105).

Because KARP and Te Papa are not the legal owner of human remains and the final stage of this research is to find their iwi affiliations, the members of this repatriation programme can be introduced as kaitiaki. The western tendency to classify and unitise Indigenous knowledge (Tuhiwai Smith 2012) can also be perceived in French museology since the colonial period and in its consideration of Indigenous perspectives for decades. The academic research and publications regarding relationships between museums and source communities have greatly increased since the beginning of the $21^{\text {st }}$ century (Peers and Brown 2003; Butts 2003; Knell 2007; Crooke 2008; Genoways 2006; Tapsell 2011; McCarthy 2011; Schubert-McArthur 2014; Horwood 2015). From a global European museum perspective, it is also better understood that source communities have strong desires to reconnect with their collections. Source communities have been increasingly involved also in the exhibition and conservation of collections throughout Europe. As Rick West describes, concerning the National Museum of the American Indian in Washington D.C:

First, while acknowledging our deep past, native peoples want to be seen as communities and cultures that are very much alive today. Second, we want the opportunity to speak directly to museum visitors through our exhibitions and public programs, and to describe in our own voices and through our own eyes the meanings of the objects in the museum's collections and their 
importance in Native art, culture and history. And third, we want the museum to act in direct support of contemporary Native Communities.

(West 2004 cited in Hakiwai 2014, 13)

Here I have identified a significant gap in the literature regarding the way that relationships can be built between museums and source communities. In modern museum practice, the literature suggests, there is a desire to create long-term communications between places where treasures are stored and their communities of origin. Many questions are still unanswered, particularly how to begin a genuine relationship when the balance of power is uneven in the first place. In this study, inspired by the concepts of "contact zone" (Clifford 1997), "liberating culture" (Kreps 2003), and "interaction and movement" (Thomas 2016), I will analyse how repatriation in France is considered as the inception of this process of integration of Māori perspectives within museums. I will also analyse how repatriation as a museum practice generates new dialogues between French and Māori authorities. By understanding Toi moko as a "material maker of relationships" (Thomas 2016, 19), we can see the repatriation process as a method for which these mutual efforts can be employed.

\section{Museums and Repatriation}

Repatriation is often the beginning of ongoing relationships between Te Papa and international institutions - where information and research is shared and future joint endeavours explored. The benefits experienced from repatriation can extend to all facets of an institution. (Karanga Aotearoa Resource 5, 2)

In assessing the literature for this review, I have examined a number of sources for relevant material and identified a wide of range of literature that considers the experiences of museums with repatriation, museums and Māori practices related to the repatriation process, as well as theories that frame this subject. During my internship at Te Papa in 2012, I read several reports, books and articles on repatriation (Davies 2002; Te Awekotuku 2003; Butts 2003; Smith 2004; Hole 2007; International Symposium 2008; Pānui of the KARP and annual reports of Te Papa). Even though this thesis is focused on French case studies of repatriation, it seems important to emphasise that this return from France to New Zealand is just another example of the repatriation practice of Toi moko internationally. There are many publications on the dichotomy of human remains in museums that discuss whether their future lies within the museum collection or in their land of origin (for example Arvanitis and Tythacott 2014; 
Atkinson 2009; Bennett 2005; Butts 2003; Charlier 2014; Davies 2002; Gathercole 1990; Hole 2007; Neich 1979; Smith 2004; Tapsell 2002; Thomas 1991, 2016; Gagné 2012; Macdonald 1996; Fforde 2002; French press release related to the official repatriation of Māori heads from French museum collections 2012). As one prominent study puts it: "[r]estitution is not only about the loss of objects for museums, but can be about important gains in term of cultural relationships and knowledge" (Thythacott and Arvanitis 2014, 8).

The loss of scientific usefulness of human remains in museum collections or the loss of the object itself were apprehensions that developed rapidly among professionals of the French museum sector (International Symposium 2008). Repatriation has been seen progressively, therefore, as having cultural benefits to obtain not only global understanding on Toi moko but also understanding of Māori taonga in general. The research undertaken in this study combines tikanga and French museology in order to create a global understanding of Toi moko. Repatriation is also an opportunity to nourish a new relationship by gaining more understanding of Māori cultural identity provided by Māori themselves. French museums are very strict about international repatriation processes. The support of the national authority for source communities is one of the most essential conditions in order to convince French museums to proceed with repatriation. In this particular situation, French museums decided to support the return of Toi moko without knowing the detailed origin of each ancestor. Support from Te Papa and the Ministry for Culture and Heritage had significant influence in this negotiation by demonstrating national support in New Zealand for the repatriation programme. As Peers and Brown point out:

A major repatriation issue for museums is the question of who, or which community, is the appropriate recipient for material. Except where an individual can prove clear legal title, general practice favours returns to the source community for an object or collection. The process of repatriation is complex and needs to be transparent to all parties involved. (Peers and Brown 2003, 21)

Reflecting issues associated with the imbalance of power created by colonisation by Western settlers, repatriation requests have become contemporary challenges for museums. However, museum professionals now have opportunities to discuss requests with the authorities of source communities in order to gain more information around the status of their ancestors and the importance of seeing them back home. Peers and Brown reflect on the ongoing imbalance 
by referring to the 'appropriate recipient' $(2003,21)$. It seems that even if the request is considered to be ethical and right, the final decision remains under the museum's authority which is characterised by its conceptualisation of ownership. This inequality can be reduced by enabling source communities to have responsibilities over their own ancestors. Furthermore, by involving diverse professional panels (such as researchers, managers, directors, curators, social science researchers and politicians) the network and the relationships seem overly complex to create and, moreover, to maintain.

The benefits, in terms of information exchange and intercultural engagement, are the reason why I chose to analyse this process of return as a museum practice. Research on Toi moko encompasses information about human remains in modern times and research on the shared historical exchange between French and Māori from the first acquisitions. The old definition of museums does not apply in this discussion. Repatriation is driving different values from the traditional view of the museum which is too centred on Western thought (Kreps 2003). Reflecting globalisation and contemporary international museum practice, no museum system can operate in an isolated environment. Each museum creates structures and systems linked to other neighbouring institutions. The literature encompasses this global idea of the changing museum.

This is not a comparative study between French and New Zealand museum management. I will look at various stages of negotiation in the repatriation process and analyse the research generated by this international practice. As Peers and Brown argue on the global understanding of repatriation:

Reconciling issues of ownership represents a complex and difficult part of contact work. The first reaction of museums to challenges from indigenous communities has often been fear that mainstream museums would lose the right to hold or exhibit indigenous materials. Thus far legislation including the Native American Graves Protection and Repatriation Act (NAGPRA) passed in the United States in 1990, and policies developed by national museums associations in Canada (Task Force 1992) and Australia (Griffin 1996, Fforde et al 2002) have been fairly conservative with regard to the outright return of museum collections to indigenous communities. Some collections have been, and more will be, returned to communities, with the greatest emphasis placed on human remains and classes of objects deemed 
essential to the continuation of traditional cultural practices and identity.

(Peers and Brown 2003, 21)

Repatriation has already been extensively theorised and is still considered to be a controversial topic in the global museum environment. This study, therefore, provides additional insights into the repatriation of human remains as a modern practice in the global museum environment (O’Hara 2012, McCarthy 2014, Peers 2017) and even more recently for French museums. As Anthony Shelton points out:

If the transformative potential of repatriation is to be fully realized, it needs to be understood in connection with the many complex networks of relations that exist between museums and communities. Future studies need to include the total field of prestations between museums and communities; the need to develop understanding of the adoption and implementation of, different bureaucratic, legalistic, and ritualized forms in which such relations are expressed. (Shelton 2017, 93).

The repatriation process is ideally a form of collaboration that can insert inclusive speech into the museum gallery. Some argue that Eurocentric theory is not appropriate for the museology of ethnographic collections in the $21^{\text {st }}$ century (Kreps 2006, 456). And Anthony Shelton identifies repatriation as a method to clarify and understand the complex international sociopolitical context in which museums are located.

The literature reviewed in this section has examined key bodies of knowledge that help to shape my cross-case analytical framework in order to answer my questions related to repatriation as a museum practice; How is the process of repatriation, from negotiation to international collaboration post-repatriation, providing new understandings about Māori human remains in collections in French museums?

Some topics have not been studied yet, particularly the French involvement in the Toi moko traffic and the context of acquisition within museums. I highlight the gap that exists between France and New Zealand on the understanding of what Toi moko are. I show how this meaning has been evolving through time, and the different decisions that led to the return of Māori ancestors to New Zealand. In order to analyse this repatriation process, I focus on the key issue of the fuller and more thorough understanding between museums and source communities (Shelton 2017), the transparency of all parties in the museum context (Peers and 
Brown 2003) and the balance between gains and losses in term of physical material and cultural relationships and knowledge (Arvanitis and Tythacott 2014).

\section{Cultural Diplomacy}

Throughout the repatriation process, diplomacy was a key issue from the beginning of negotiations up until the post-repatriation collaboration. Cultural diplomacy in museums is the subject of some debate among international authors (Bayly-McCredie 2016). Nevertheless, M.C. Cummings' theory is relevant within the cultural repatriation field, despite his focus on the conceptualisation of the cultural diplomacy by the United States government. He started his survey by declaring that "the concept of cultural diplomacy refers to the exchange of ideas, information, art and other aspects of culture among nations and their peoples to foster mutual understanding" (Cummings 2003, 1). Diplomacy seems crucial within repatriation negotiation because this topic generates modern museum challenges and debate on the balance of power: national-local museums, inclusive museum practice-cultural separatism, scientists-repatriation officers, and former colonial-colonised countries and French-Māori perspectives.

Museums have a tremendous responsibility and opportunity to be effective agents in post-colonial reconciliation. In New Zealand we have seen the development of a strong, assertive confidence, health, education, and selfesteem, well-being, sense of place in the world. A sense of place that, in the colonising period was taken away. Museums need to think carefully about the responsibility they have in this process. (International Symposium 2008, 107)

This was the declaration by Seddon Bennington, then chief executive officer of Te Papa, during the fourth roundtable, 'How to reach a mutual understanding? Institutional mediations and negotiations', of the International Symposium held at MQB-JC in 2008. He focused his speech on the "mutual respect" that museums had to establish in order to create, or maintain, strong cross-cultural diplomatic relations. At this stage of the negotiation for the repatriation of Toi moko, the repatriation could be considered to be a practice that realises this common interest to work together. "Te Papa was founded to work with museums internationally, to 
facilitate a process, to work both with Māori in New Zealand, in terms of resting place, really to be a facilitator' (Seddon Bennington quoted in International Symposium, 107).

The dialogue between institutions is crucial during repatriation negotiations. In this last quote, Seddon Bennington highlights the influence of museums in those international operations. Repatriation is consequently not only about the final return of Māori ancestors but also about a process of exchange. That's why Seddon Bennington put such importance on the fact that museums are not about status, but respect.

Philippe Lane employs an expression borrowed from Julia Kristeva-Joyaux in order to define cultural diplomacy. He writes that "The problem is to escape from this bureaucratic mountain in which cultural and scientific institutions and organizations are operating with no overall global cohesion" (Lane 2013, 3). Museums are facing challenging contemporary issues due to globalisation, new methods of communication and international relationships. However, museums are also the places where the public, in a wider community definition (Davidson 2015), can learn from each other. Museums are not only places of exhibition but also of reflection on those issues by using the institutions for the "exchange of ideas" (Cummings $2003,1)$. They are seen as a "facilitator" in order to gather together researchers who are attempting to answer problematic international questions such as repatriation. The balance of power between museums internationally and nationally can also be seen in those crosscultural communications. In order to be heard worldwide, Indigenous voices are using museums. Supported by the collection, they can develop their expertise on objects made by their ancestors. As Sally Price writes in her book Paris Primitive in 2007: “the museum's role in international diplomacy has been particularly evident in Australia and New Zealand" (Price 2007, 219).

The reception of the International Symposium at MQB-JC at the beginning of the conversation with Te Papa on the topic of repatriation clearly showed the important diplomatic role played by the museum in societies today. Many speakers during those round tables acknowledged Stephane Martin, director of MQB-JC, for organising such a controversial discussion (quoted in International Symposium) that could lead to the return of some collections. As Timothy W. Luke points out, "Museums are serving as central nodes in social cultural networks formed by states, governments, and communities to cultivate national character based on the premise that culture is an incubator of character" (Luke cited in Grincheva 2013, 40). Research, therefore, focused on the role of cultural diplomacy in 
modern museum activities. Melissa Nisbett, for example, conducted consequential research on cultural diplomacy and instrumentalism in museum and cultural environments (Nisbett 2013). Her research focuses on the tendency for museums to use political rhetoric in their relationships, calling for a conceptual rethinking and, therefore, creating a new perception of museum's role within contemporary international relationships (Nisbett 2013, 1).

Analysing the repatriation dialogue between France and New Zealand as a form of cultural diplomacy allows me to examine the ways in which, like these other examples in the literature, it aimed to strengthen bonds, acknowledge positive interaction with other communities, and foster awareness and understanding of different cultures (Grincheva 2013; Bayly-McCredie 2016). The role of museums in France has been significant in the crosscultural diplomacy engaged in with KARP. It is also this quality of communication and relationships that generates some post-repatriation collaboration as we could attest in Rouen or in Paris with the two different exhibitions cited earlier, where both used contemporary inclusive speech in their museology. "Cultural diplomacy implies the use of the art of diplomacy," writes Natalia Grincheva, "in promoting culture resulting in a potential greater awareness of each other's cultural backgrounds" (Grincheva 2013, 39). In international operations such as these, cultural diplomacy is a key part of the dialogue. Cultural diplomacy defines the nature of the relationships and seems important not only in the development of the negotiation but also through post-repatriation collaboration. During the repatriation process, cultural diplomacy could be considered as a way to develop a shared objective by understanding each other's apprehensions and ambiguities.

Furthermore, each repatriation case study, or negotiation at least, is different because of the nature of the relationships. French museums didn't have much of a relationship with Māori before the first conversation was held. Added to that, France wasn't the empire that colonised New Zealand. In the case of the repatriation of Ataï's head, the nature of relationships between France and New Caledonia were characterised more by cultural and political pressure (Patin 2014).

The literature review in this section illustrates the significance and value of cultural diplomacy as a theoretical lens through which to view the international relationships of museums. It also reveals a gap in the process of generating those intercultural relationships. How are museums, related to governments, playing a key role in discussing repatriation with source communities? In what ways can repatriation be considered a practice that can embody 
this inclusive approach towards cultural representation through museum collections? In answering these questions, I will use the theory of cultural instrumentalism in museums (Nisbett 2013) and focus my study on the definition of cultural diplomacy in terms of the "exchange of ideas" (Cummings 2003) and as a method used in museums for promoting cultures (Grincheva 2013). Those concepts are advanced here as a key theory employed in order to understand diplomatic challenges faced by museums during the period of repatriation negotiations.

\section{French museums and repatriation of human remains}

[...]one of the most difficult issues seeking resolution by museums in the post-colonial era is that of repatriation. (Simpson 1996, 171 cited in Kreps 2003, 3)

As a former colonial empire, France is consequently the recipient of several requests for repatriation. France collected human remains from all around the world from the beginning of its colonial empire. In this study I will analyse how repatriation reflects the unique and sensitive history of Māori ancestral remains that became museum collections and the story of their acquisition in the colonial period.

The first international repatriation between France and New Zealand and the negotiation around this case study of Toi moko emphasises the constantly changing meaning of human remains stored in museums. "Despite their potential, the study collections have often known different stages of development and abandonment throughout their history, the most extreme outcome sometimes leading to their pure and simple destruction," writes Cadot $(2007,6)$. Originally considered by Europeans as curios, human remains are today regarded more as scientific components studied in order to understand the evolution of humankind (Patin and Jean 2010; Gagné and Roustan 2014).

My research, however, explores not only the ways in which the repatriation requests have led to people reconceptualising new means of seeing and working on human remains but also new approaches to museum ethnographic collections in their broader sense. Because repatriation had been interpreted as a negative action at first by some museum professionals (Picq 2012; Phillips 2014), this debate was seen as an opportunity to challenge French museums about their ways of exhibiting and preserving foreign collections from existing source communities (Butts 2003; Kreps 2003; Dupaigne 2006; Price 2007; Hakiwai 2014; 
Alivizatou 2012; de L'Estoile 2007). Since 2000, French museums, specifically, ethnographic and natural history museums, were exposed to several transformations of their ontologies and professional paradigms (Roustan 2016; de L'Estoile 2007, 2008). These debates about repatriation have also highlighted the relationships of French public institutions with their colonial pasts and the actual minimal networks between them and source communities. This new approach can be seen in the analysis of the relationship between the young MQB-JC and its collections (Dupaigne 2006; Price 2007; Vogel 2007; Alivizatou 2012; de L’Estoile 2007).

Sebastien Minchin told conference attendants at the University of Rouen "the French national collection is composed of 75 per cent natural history collections". ${ }^{1}$ There are, however, many kinds of objects under the label 'natural history' and each category requires specific preservation conditions and storage. Anthropological collections are part of sensitive collections because of their human nature and the preservation protocols they require (Patin 2014). Repatriation is a result of this new approach to museum practice and underlines the tension between cultural assessments and scientific speeches (Peers and Brown 2003; McCarthy 2007, 2011; de l'Estoile 2007; Thomas 2013 or Roustan 2016). In January 2012, Michel Guiraud, director of collections at MNHN in Paris explained the position of the museum by highlighting the coexistence of two spheres in museum policy; cultural and scientific. According to him, the MNHN is attempting to gather in its collection the most exhaustive representation in the world of nature including animals, plants but also human remains in order to obtain the most complete definition possible of universalism. ${ }^{2}$

It is often said that French museology and curatorial practice aim to distance objects from their original use (de L'Estoile 2007; Roustan 2016). Because taonga are appreciated as art in France, they were regarded to be "dead pieces" (Alivizatou 2012; Tuhiwai Smith 2012) in comparison with the views of their source communities and their meaning held by New Zealand museums (Mead 2003; McCarthy 2007; Tapsell 2011; Hakiwai 2014). As Sharon Macdonald pointed out in the 1990s "Museums are socially and historically located" (Macdonald 1996, 5). While it is true that historical divergences, such as perspectives held by the coloniser as distinct from those held by the colonised, have underpinned the negotiation of repatriation, the changing interpretation of history and the differences brought about through

\footnotetext{
${ }^{1}$ Sébastien Minchin, 'La fabuleuse histoire de la tête Maorie de Rouen', conférence Université de Toutes les cultures, November 24, 2014, 7'min.

${ }^{2}$ Musée de l'Homme, (2012) La question de la restitution des restes humains, Restitution des têtes maories, tout public 2/3, 17:32, July 252016,14 'min,.
} 
such a process, and the new ideas about museums, have contributed to reaching a final decision concerning these ancestors (Cadot 2007; Patin 2014; Gagné 2013; Roustan 2016).

This French case study enables us to recognise also Nélia Dias's observation on the rhythm by which museums are changing in France and particularly in Paris (Dias 2007). Every 50 years, approximately, a new museum is created in Paris in order to confront the older ones and their old-fashioned ways of exhibiting collections. We can see how difficult it is, therefore, to define a role for non-European material culture. Although France is rethinking the role and status of the ethnographic collections already held in its museums (de l'Estoile 2007; Roustan 2016), we can also observe this change through the creation of new museums all around the French territories, such as the MQB-JC in 2006, the National Museum of Immigration History in 2012 or the reopening of the Musée de l'Homme in 2015. But this desire for change is not applicable uniquely to Paris and can be seen in different important cities such as the creation of the Musée des Civilisations de l'Europe et de la Méditerrannée in Marseille in 2013, Le Louvre-Lens in 2012, and the Musée des Confluences at Lyon in 2014 (Roustan 2016). The ever-changing mutations of institutions have consequently initiated a 'heritage digestion' (Monjaret and Roustan 2012) that relies upon a dialectic between here and a somewhere else 'cannibalised' (Gonseth, Hainard and Kaehr 1984 cited in Roustan 2016), that is sometimes integrated within the nation, and sometimes related to the universalism to which France would like to continue holding the key (Roustan 2016, 154).

Human remains are considered to be one of the most sensitive collections in France (Cadot 2006; Cornu 2006; de l'Estoile 2007). Because of the nature of the collection, France has had to develop one specific museum policy in order to answer those requests made by source communities (International Symposium 2008). By highlighting this controversial approach to collections (Price 2007; Désveaux 2002; de L'Estoile 2007; Dias 2008, 2014; Harney 2006; Picq 2012) I will analyse the changes made to those former approaches which were prompted by the contacts made through repatriation between French museums and Indigenous people.

There is a significant gap in the literature between the ontological definition of museums in France and New Zealand repatriation practice. Today, repatriation is increasingly seen as an important aspect of contemporary practice which the French museum sector is struggling to incorporate in to its museums policy. The literature suggests this changing paradigm of repatriation is being slowly picked up by professionals within French museums. I stress, here, that repatriation practice is a new element that places "paradoxal injunctions" (Roustan 2016) 
on dilemmas such as those between universalism and local, religious and secular entities, and finally the repatriation of Toi moko provides a new opportunity for interlocution (de l'Estoile 2008; Alivizatou 2012; Gagne 2013; Roustan 2016). Finally, as was concluded by Patin in 2014, human remains in France cannot be subjected to simple categorisation.

\section{Repatriation in New Zealand}

Even though the issue of repatriation is debated also in New Zealand, the process is considered generally to be a model of collaboration and consensus between the government and Māori (Hole 2007), witnessed by the assertion of tino rangatiratanga (self-determination) in the kaupapa (policy or scheme) proposed by museums since the 1980s and the impact of the Te Mãori exhibition (Mead 1986, 2003, 2012; Tapsell 2003, 2011a, 2011b; McCarthy 2007, 2011, 2018). As McCarthy points out:

In the 1960s and 1970s New Zealand history became a subject in schools and universities, and there was keen community interest in local museums, historic buildings and heritage sites. Then came a museological revolution. In the 1980s the famous Te Maori exhibition changed the direction of New Zealand museums and became a touchstone for the Māori Renaissance, a dramatic resurgence of Māori people, culture and identity that had been gathering pace for some time. (McCarthy 2018, 32)

This exhibition had direct effects on the use and interpretation of Māori collections. It also contributed to the emancipation of Indigenous cultural identity, always under the impetus of this desire for self-determination, tino rangatiratanga. Rhonda Paku argues that:

It was a catalyst for Māori awakening to the fact that our taonga had real value elsewhere in the world. It was the first time I had seen our taonga on TV shown in such a cherished and valued way. It was an awakening to how we ourselves perceived the taonga as real treasures and not just things to be left in museums without a voice - we needed to provide that voice. (Paku in McCarthy 2011, 63; Quoted in Tapsell 2014, 3)

Through the importance given to taonga by professionals at Te Papa and the respect given to the values held by their tribal owners, Te Papa maintains rules associated with these objects, whatever their nature. These rules are directly dictated by tikanga combined with the criteria 
of preservation applied in this type of institution (Evan 1996; Hakiwai 1988, 1999, 2005; McCarthy 2007, 2011, 2018; Simpson 1996).

Investigation by Indigenous repatriation practitioners into the strategies used by authorities, such as KARP and the Repatriation Advisory Panel (RAP), has recognised that repatriation has contributed to worldwide recognition of Māori identity. Thanks to the repatriation process, foreign museums have a better understanding of the significance of the link between living peoples and ancestors (Butts 2003; Fforde, Hubert and Turnbull 2002; Besterman 2006). The creation of KARP itself, it could be argued, is a product of a postcolonial bicultural national identity which had to come to terms with conflicts between Māori and the Crown (Butts, 2007; Orange, 2011; Belich 2001; Poata-Smith 2004; Ranginui 2004; Wolfe 2005). This framework impacts on questions around biculturalism in New Zealand and particularly inside the national museum Te Papa where KARP is located (O'Reagan 1997; sir Kingi Ihaka 1989; Tapsell 2011; Williams 2005; Butts 2002, 2006, 2007; Johnstone 2006; Karp and Steven 1991; McCarthy 2007, 2011, 2018; Nesus 2004: O'Hara 2012: SchubertMcArthur 2014). In addition to the bicultural framework established in New Zealand museums, the creation of exhibitions by Māori museum professionals was the result of a desire to enable Indigenous people to present their own perspectives of the past and their influences on modern sociological structures as was the case with the exhibition Te Maori in the 1980s (Mead 1986; McCarthy 2007; Price 2007; Poulot 2001; Salmond and Thomas 2010, Sciascia 2012; Mane-Wheoki 1996; Desvalles and Mairesse 2007, 2010).

However, several distinctive factors appear to have allowed difficult issues related to the connection between museum, repatriation and Māori in New Zealand to be resolved to a greater degree in New Zealand than elsewhere. These include: historical precedents of interaction between museums and their local Māori communities; active Māori involvement in the process on both sides (that is, both inside and outside museums); and the direct involvement of the government as a broker for resolving individual claims (McCarthy 2014, 72).

Studying the implementation of Māori perspectives within museum practices, such as curation, exhibition and knowledge transmission, led to the establishment of the repatriation programme within Te Papa. From my foreign point of view, I focus here on the role of the repatriation programme internationally and how it encompasses tikanga Māori which has established a role for Māori within museums. In this thesis, I observe the ways in which the 
repatriation process is an integral part of the politics of biculturalism championed by Te Papa. This is shown in the use of cultural materials and speech in a political dimension in order to resolve a dialogue between two models of museums, Western and non-Western (Kreps 2006) and leads to the notion of the museum as a "contact zone" (Clifford 1997).

The literature on repatriation in New Zealand reflects the renewal of museum activity and change in New Zealand over the past 30 years. Since the exhibition Te Maori, the involvement of Māori in museum activity has continually increased. I will analyse the implementation of KARP within museum practice at Te Papa and discuss how the programme is challenging French museums in terms of their colonial model of museology. I will finally analyse how the repatriation programme could be thought of as an instrument to create partnerships and build bridges in order to spread Māori perspectives within French museums.

Current literature (Davies 2002; Te Awekotuku 2003; Hole 2007: McCarthy 2007, 2011, 2013, 2014, 2018; O’Hara 2012; Hakiwai 2014; Aranui 2018) shows that the topic of repatriation is compelling in New Zealand. However, there is a lack of material published about the practical application and the implementation of repatriation activities in the museum environment. By exploring repatriation as a practice (O’Hara 2012, McCarthy 2014; Hakiwai 2014; Aranui 2018), I would like to analyse the repatriation protocols used in the French case study. Additionally, the repatriation process is founded on the concept of cross-cultural engagement within Māori cultural recognition. The repatriation process can be seen as a practice by highlighting not only iwi involvement within the process, but also international negotiations seen in this case study. This present research differs from previous studies as it analyses data and results obtained during several internships and contracted missions as a repatriation researcher. This includes my fieldwork in both New Zealand and France.

\section{Theoretical Framework: The repatriation process as a post-colonial museum practice}

Repatriation requests still involve debate and controversy, particularly when human remains are the subject of negotiations. Appeals for return can be a catalyst for a new approach to establish international relationships, more precisely between the country which receives the request and the source community. Although repatriation of Māori human remains has been discussed in New Zealand for 30 years, in France the issue was relatively dormant until recently when the role of Toi moko, and human remains more generally, in French public collections started to be examined more closely. For this study, a theoretical framework drawn from the literature discussed above allows me to deal with negotiations and interactions 
between two contemporary parties — one, a tribal community represented by KARP located in the national museum and the other, museums and universities within a colonising country. This thesis therefore explores the transnational practice of repatriation through a situational approach drawing on ethnography, museology and crosscultural communication theory. By using Clifford's concept of museums as a "contact zone" (Clifford 1997) and thinking of objects as a "material maker of relationships" (Thomas 2016) in the approach to "liberating cultures" (Kreps 2003), I identify and analyse the museum as a public cultural institution, a platform where debates and discussions on repatriation have to be elevated.

The questions about the return of Toi moko led French museums to examine the ontological differences concerning these ethnographic collections and essentially drove the changes in attitude and practice explored in this study (Cadot 2006; Gagné and Roustan 2014; Gagne 2013; Le Louargant 2008; Mead 1983; Besterman 2006; Benoit de L'Estoile 2007; Thomas 2016). Because the focus of these requests was mostly museums, we need analytical tools that can help to analyse the internal dialogue and debate within these cultural institutions in order to answer the many ethical issues that arise from the return of Toi moko (Besterman 2006).

The analytical framework employed in this study is assembled from several theories that help to guide my approach to repatriation. One of the major gaps identified in the review was the lack of attention paid to the actual practice of repatriation. The writings of O'Hara (2012) and Aranui (2018) and their insights and observations of repatriation in New Zealand museums, as well as the work of McCarthy and his writing on the role of repatriation as a practice in the New Zealand museum sector (2014), help me to shape my understanding of repatriation as a museum practice which involves specific policies, agreements and processes. In terms of international museum studies, Macdonald et al (2006) focus on the (re)definition of museum practice and the increasing role of repatriation within it. In the French museum context, Roustan $(2014,2016)$ helps me understand the role of repatriation in the deontological changes in the French approach to human remains. Peers and Brown (2003) and their research on relationships between museums and source communities inspired my understanding of the challenges faced by all parties and the need to create relationships. In the cultural policy area, Nisbett (2013) and her concept of instrumentalism in cultural environments helpfully described the place of museums in international diplomacy and their role in international politics. Finally, Arvanitis and Thythacott (2014) embody the current analysis of the contemporary process of repatriation within the global museum environment. This literature review, therefore, has revealed key concepts which have helped me answer the question: how 
has the repatriation process helped French and New Zealand museums to create partnerships and gain greater understanding of each other's perspective even after the loss of a part of the collections.?

This literature review has identified plural perspectives on the repatriation of human remains and their previous preservation in French museum collections. By studying the evolution of the role of Toi moko and their meaning inside French collections, this thesis reflects the contemporary necessity to connect the archives to tikanga, in other words Māori cultural practices, in order to create a dialogue around those Māori ancestors. Even if repatriation is a topic of much writing, there is still a lack of research about the actual procedure of how to do it and how the complex negotiations and the dialogue can be undertaken. In other words, it seems we have to focus on how to apply the theory (Davies 2002; Hole 2007; O'Hara 2012; McCarthy 2011, 2014, 2018; Pickering 2015; Peers 2017; Aranui 2018), how to actually do repatriation in practice with Indigenous people.

The literature review has also revealed the many perspectives involved in the operational process of repatriation and how those views could influence one another. Toi moko have a key role Māori culture, and French museums have participated in the politics of Indigenous recognition in which the repatriation process is having a significant role (Butts 2003). Additionally, the repatriation process has effectively advocated Māori influence in other museum activities such as festivals, exhibitions and events, and expressed Māori perspectives on French museum collections and ways of doing things.

Finally, the literature review shows a significant gap in writing on the relationships between museums and source communities in terms of Indigenous perspectives (Kreps 2003, 2011, 2017; McCarthy 2011, 2015; Aranui 2018), but also in the study of repatriation in its operational process as part of professional museum practice (McCarthy 2014; O’Hara 2012). This research, therefore, explores how the repatriation process can be regarded as a postcolonial museum practice, and how this process illustrates fluctuating and disparate approaches towards Māori human remains in French and New Zealand museums.

Furthermore, I see museums as places where encounters are necessary in the $21^{\text {st }}$ century. The museum is a platform where borders or lines which have defined its identity can be redefined or reframed according to the context and the contemporary challenges faced by the society in which it is located (Macdonald 1996). Thinking of repatriation as a post-colonial museum practice highlights the role of cultural diplomacy (Grincheva 2013) in the negotiations, using 
museums as "facilitators" (Bennington 2008). Initially, Māori culture was placed in an inferior position in museums in order to confirm an evolutionist vision and a racist position on different cultures (Pagani 2014). But today repatriation negotiations foster awareness and understanding of different cultures. The concept of 'instrumentalism' (Nisbett 2013) suggests that an inclusive policy in French museums is relevant in the context of repatriation. French museums can reconnect with current Māori cultural identity and try to get rid of its former folkloric perspective by inviting curators, researchers and artists into their galleries. This invitation therefore puts "paradoxical injunctions" (Roustan 2016, 169) on French museums which can lead French authorities to rethink the museum's form and purpose by putting a greater emphasis on the practice of repatriation within their museum activities.

\section{Research design}

The research design for this thesis progresses from an understanding of the debate around human remains in France to the acknowledgment of the tikanga that defines the actual link between ancestors and living Māori communities today. The overall approach to the methodology that I employ evolved thanks to my previous experience and my direct engagement, in France and New Zealand, in the negotiations and the procedures for returning tūpuna. It seems obvious at this time to provide a French 'insider' perspective on the organisation of the repatriation programme and its policy. The position of repatriation practitioner was new in France and my experience at KARP changed my perspective on the appropriate methods with which to complete this $\mathrm{PhD}$. Working as an intermediary beside researchers at Te Papa, in Museum and Heritage Studies at Victoria University, and with anthropologists in France and also museum professionals and politicians in both countries involved in the return of Māori ancestors, all helped me to frame key questions to which France and New Zealand were expecting answers.

Even if repatriation in general was already debated in France, my work at KARP and my participation in the understanding of the repatriation as a practice helped me to clarify my approach to this controversial topic. Originally, my enquiry was based on questions asked in France about the repatriation policy at Te Papa, but with a growing involvement in the negotiation process, personal questions were raised particularly about what repatriation can offer in terms of international relationships and museum practice. Because this topic raised several questions on both sides of the negotiations, the primary research question was mostly articulated in relation to French authorities (political personalities, museum professionals and 
researchers) and initially concerned the definition of Toi moko according to Māori iwi in order to understand the reasons why the programme was created. How has repatriation practice raised awareness in terms of global understanding of the past and present life of Toi moko? This question sought an explanation of the context of acquisition by French museums and of how this research might help to recognise the entire story of these ancestors.

The second question focuses more on the practice of repatriation within the museum environment. How have disparate cultural perspectives on Toi moko led French museums to rethink their approach to human remains but also to taonga? Furthermore, how can Toi moko be considered as art/science objects within museum collections? On which points was the debate based in France and why did the process take four years to proceed? What are the protocols and criteria we have to respect during repatriation?

My vision of the topic changed while working alongside Māori staff at Te Papa and repatriation practitioners in New Zealand, so I wanted to use this opportunity to interrogate the nature of post-repatriation research. By examining kaupapa Māori and its significance in museums, I focus particularly on how repatriation can initiate and advance the dialogue between museums in order to learn more about Māori cultural identity and relate it to the taonga still stored in French collections. Starting with the attempt to define Toi moko, I came to understand the intimate relations between Toi moko and tikanga, and how the process of repatriation can help a foreigner to learn about current Māori collective thought about ancestors, genealogy and death, and how those concepts affiliated with the principle of selfdetermination which was central to the process of returning ancestors.

The multi-dimensional nature of the topic and the international nature of the procedure framed my understanding of the constant changing paradigm on which repatriation is based, especially when this procedure is regarded as a museum practice. So as to address the practical questions of French professionals, and address these research questions above, I have applied qualitative and inductive methods in this research and immersed myself in the process of repatriation in France and in New Zealand. The literature review surveyed key writings associated with museums and repatriation or museums and source communities, and constructed an interdisciplinary theoretical framework including the concepts of 'contact zone' (Clifford 1997) and 'liberating culture' (Kreps 2003). With the archival research involved, I employ historical archival methods. Due to the nature of the topic working with Māori professionals in museums, I also employ a kaupapa Māori methodological framework. 
Because the case study of the repatriation process between France and New Zealand was initiated in cross-cultural communication, qualitative methods seem to be appropriate to explain the influence of this programme on the approach within the museum environment. Through semi-structured interviews I explore the impact of the process dealing with human remains on museum practice and on the ways in which ethnographic collections are stored in French museums. Therefore, I observe the repatriation negotiations in the French museum environment and apply an inductive methodology in order to describe the process of negotiation and analyse it as a model to follow in terms of international repatriation practice. For all these aspects of the doctoral project, obtaining ethics approval was necessary (Application ID: 0000026851 obtained in February 2019), requiring ethical processes to be followed for the interviews including informed consent from participants, information sheets etc. I finally decided to use figures throughout the thesis to give more substance to the description of some events that characterised the repatriation projects such as ceremonies. Some of these have been taken by myself during the research but I also got the permission from Te Papa to use photographs taken by Norman Heke (former photographer and imaging specialist at Te Papa) of the repatriation that occurred in January 2012.

\section{Methodology}

The methodology I employ in this research has evolved from the time I worked on my master's degree in 2008. In reflecting on my internships in 2009 and 2012 at Te Papa, it is apparent that ethnography and participant observation were key methodologies utilised in order to gain deeper insights into the process by which French and New Zealand museums interacted in the repatriation process. Nevertheless, when I went back to France, I started to formulate more clearly a case study methodology to develop this research. Case studies are a key approach used to analyse this process empirically and to analyse its results for French 
museums. I also chose to undertake this research by means of the application of an interdisciplinary approach in order to present a realistic analysis of this controversial topic.

So, in summary my methods are:

- Historical archival research

- Case studies

- Action research

- Participant observation

- Semi-structured interviews

- Kaupapa Māori methodology

\section{Historical archival research}

In the historical background to the French acquisition of human remains in this thesis I am articulating a part of the research around primary source documents found in different archives, in museum acquisitions books or archives in cities such as Rouen or Montpellier. Through this method of analysing primary sources in archives, I can gain a picture of the life of museums in the $19^{\text {th }}$ century. I can also understand their reasons for obtaining Toi moko for their collections. I also particularly studied texts written by explorers and scientists who travelled throughout the world early in the $19^{\text {th }}$ century including those of Louis Claude de Freycinet (1817-1819), Louis Isidore Duperrey (1822-1825), Jules Sébastien Dumont d'Urville (1822-1825; 1826-1829) and du Petit-Thouars (1836-1839). Scientist René Primevère Lesson wrote different notes about Toi moko during his circumnavigation (18221825). As well as this, I have drawn parallels between the trade and the French colonisation scheme for New Zealand. Because France and the British Crown were competing to gain control over New Zealand land in the $19^{\text {th }}$ century, I wanted to understand the importance of such a trade to the colonial ambitions of the French government-with the help of contemporary, postcolonial texts (Higgins 2004).

\section{Case Study}

The present research differs from previous studies as it analyses data obtained during several internships and contracted missions as a repatriation researcher. This includes my fieldwork in New Zealand and in France. This fieldwork is not limited to the period of time spent in New 
Zealand, it includes my time on the museum staff in Rouen during the negotiation and how my role as intermediary between the two institutions, which are the Museum of Rouen and Te Papa, led me to comprehend every stage of the negotiation and to try to understand the relationships which characterised this operation.

In order to examine the repatriation negotiations and its influence on French museum practice, Robert Yin's work on case study methodology appeared to be the most relevant research strategy. This research seeks to illustrate how repatriation in France is a consequence of the constant evolution of museum practice. According to Yin "a case study is an empirical inquiry that investigates a contemporary phenomenon with a real-life context, especially when the boundaries between phenomenon and context are not clearly evident" (Yin 2002, 16). In this research, the "contemporary phenomenon", as described by Yin, is repatriation. The aim in France was how to develop the best way to manage the repatriation of human remains. In this thesis I conduct an investigation that provides a broad picture of repatriation in France according to my experience and my perspective on this controversial topic. Moreover, case study methodology analyses a situation, individual, event, group or organisation (Wisker 2008). In this study, the situation is temporally and spatially limited. From the launch of the repatriation procedure by a French museum in 2007, the debate among museum practitioners, politicians and academics, such as anthropologists and scientists, continued up to 2012 with the actual return of Māori ancestors. Even if the negotiation period (between 2007 and 2012) is the temporal foundation of this study, it is important to indicate that the timetable of this case study is ongoing (beyond 2009 and 2018) in order to study the post-repatriation relationships maintained by the two countries concerning taonga in the most general definition (including human remains).

Schramm illustrates the usefulness of case study research by writing that "the essence of a case study, the central tendency among all types of case study, is that it tries to illuminate a decision or set of decisions; why they were taken; how there were implemented; and with what results" (Schramm 1971, cited in Yin 2014, 12). The Museum of Rouen and the other museums decided to repatriate numerous Toi moko. This decision raised several issues in relation to Toi moko and human remains in general: the controversial debate caused the museums' professionals and scientists to clarify the role of human remains in their collections and consider the lack of archival information they had on Toi moko. Furthermore, in France the lack of knowledge about Māori cultural identity, and its reinforcement through the creation of KARP in current New Zealand society, was clearly noticeable. That is why this 
research has to underpin the different steps of the negotiation up to the repatriation of Toi moko. Even if repatriation has led to tension and debates, French museums have repatriated 21 Toi moko to New Zealand and now work beside the source communities in order to collaborate with them and to increase the French museums' knowledge about Māori ancestors.

This repatriation operation of 21 Toi moko engaged 11 different public institutions (ten museums and one university). These museums are categorised differently; some are identified as natural history museums (at Nantes, Paris, Lille and Rouen), others as ethnographic museums (at quai Branly, Marseille, Lyon), fine arts museums (at Dunkerque) or municipal (local) museums (at Sens). The analysis of these different types of museums in the case studies enabled me to understand the diverse definitions of Toi moko imposed by the art market and other areas, all part of the museum evolution from the $19^{\text {th }}$ century to today. I also note the various paths of Toi moko since their acquisition by the French. Although most Toi moko were traded during explorers' circumnavigations and donated directly to museums, some were obtained or bought by private collectors and sometimes by public stores, such as Printemps, in order to exhibit them in the galleries of the boutiques. The last acquisition by a French museum occurred as recently as 1999, and the way in which human remains are viewed changed noticeably throughout the $19^{\text {th }}$ and $20^{\text {th }}$ centuries. The case study of the Toi moko from the Museum of Rouen reveals the difficulty involved in obtaining more information about the pathway of the Toi moko since its acquisition into the museum's collection. The anatomy conservatory of Montpellier example demonstrates the desire of an institution to acquire this type of ethnological artefacts in order to compare them to those of other different 'human races'.

\section{Action research}

The study of repatriation practice in museums in the current post-colonial period reveals complex human experiences. Throughout my journey as a researcher, I have gradually considered action research as a suitable research strategy that can reform museum practice. First of all, my personal involvement in the process I am focusing on has influenced my understanding of the relationships between researchers and institutions. The action research method implies a dimension of partnership that allows all the researchers from the inside and the outside to respond to the same challenges (Somekh 2005). Social relationships are in continual motion, and I do not claim to have a unique approach to the analysis of repatriation. 
On the contrary, the use of this method helps me to understand the theory focusing on repatriation practice and the concept of connection. I want to reflect on the difficulties I have encountered in order to understand the extent to which any of the practitioners have any control over their work and its outcomes.

Because of the complexity of human experience and social relationships and institutions, it will probably be impossible to plan changes and implement them exactly as intended, but action research provides means of generating knowledge about implementation of the initiative and using this to keep it on track as far as possible. (Somekh 2005, 1)

As a method, action research refers to how the study is done and how the information is collected by the researcher (Ammentorp et al 2017). I use this method in order to purposely develop the social mechanisms used to collect data. I have participated in a number of experiences that affected my personal understanding of the debate on repatriation in France and in New Zealand. During this work in the field, I have utilised multiple research techniques aimed at enhancing change and generating data for scientific knowledge production: communication, internships, research reports, translation, museum practice, diplomacy or personal inter-cultural engagement. My research is thus founded on this observation and partnership with participants to present repatriation practice and its application between France and New Zealand. Repatriation as a practice is eminently suitable for the action research method. Repatriation, like action research, is inclusive of a set of perspectives shared by a wide array of scientists and social reformers with diverse backgrounds and divergent political ideas (Greenwood and Levin 2007, 4).

Action Research is a set of self-consciously collaborative and democratic strategies for generating knowledge and designing action in which trained experts in social and other forms of research and local stakeholders work together. (Greenwood and Levin 2007, 1)

Time is also a key element in action research method in this study. Through my journey as researcher, I have constantly evaluated participatory action research as one of the main methods used to complete this thesis. Being involved in the dialogue between France and New Zealand from the first stages of the negotiation generated a changing interpretation of my role and of the topic itself. It is useful to note that: 
A common form of action research in which the researcher(s) belong to the system or the team providing the service that is the subject of the research. It is an economically viable method, but inevitably it is subject to observational biases. It may have the advantage of relatively easy linkage to interventions. (Definition in a dictionary of public health terms, Oxford University Press 2018)

I come from a heritage studies and museum practice background. Ethnography or anthropology are not university departments with which I have been engaged for the completion of this thesis. However, participant observation and action research are linked to those scholarly disciplines. During the lengthy development of my research, I also drew on auto-ethnography which I felt was relevant as a method (Schubert-McArthur 2014) in order to show how the development of the research offers a matrix in which the understanding of personal and theoretical structures is connected.

\section{Ethnography/Participant Observation}

Since my research is focused on the new cross-cultural communication (Kreps 2003) integral to the repatriation process, I am basing this study in particular on my experience as the first foreign intern at KARP.As Kreps points out, "[t]he value of ethnographic method lies in its reliance on 'participation observation', or, the collection of data through first-hand observation" $(2003,5)$.

During this internship which was in two parts: 3 months in 2009 and 15 months between 2011 and 2012, my first objective was to understand the repatriation policy that founded the creation of the KARP and its establishment at the national museum. I also had the opportunity to participate in several Māori ceremonies: four international repatriation ceremonies (2009, 2011, 2012, 2018), seven pōwhiri (welcoming ceremonies) for international and national guests. I also used the opportunity while in New Zealand to participate in a te reo class (the Māori language), and waiata (songs) and taonga pūoro (musical instruments) practices to raise my general knowledge on Māori culture. I have also been involved in the organisation and the reception of the Māori delegation during the repatriation ceremony at Rouen in May 2011. My involvement in the museum activities at the Museum of Rouen from 2008 to 2015 gave me tools to evaluate the effects of such a negotiation in France and its museum environment.

Thanks to those first experiences, Te Papa and French museums contracted me for several missions. I have kept a strong link with the members of KARP in order to give updates on the 
post-repatriation context in France and, vice versa, to enable the French museums, who contacted me, to understand the repatriation process. KARP also contracted me to obtain more information on some Toi moko case studies such as Rouen (2012) and Montpellier (2015 and 2016), and the translation of panels for the exhibition E tu Ake between its display at MQB-JC (Paris) and Musée de la civilisation (Quebec).

In the second phase, I participated in the exhibition Tatoueurs, Tatoués (Tatooists, Tatooed) at MQB-JC (6 May 2014 to 18 October 2015). In addition, I was invited by the organisation of the first edition of the festival Pacifique(s) Contemporain (4 November to 19 December 2015). All those experiences in exhibition creation and museum practices helped me to maintain the status of intermediary between New Zealand and French artists, curators and researchers.

Hui-a-rohe: This is a unique approach to gathering data in a Māori community for this research. KARP gave me the opportunity to present my research through a presentation during three hui-a rohe (regional/local meetings) in three different marae (Waitetoko Marae Ngāti Tuwharetoa; Whakatū Marae and Omaka Marae - Te Tau Ihu o te Waka). On those occasions, several researchers from Te Papa or other museums were able to develop their work on topics linked with the tangata whenua (at Taupo on 13 and 14 October 2012, Nelson on 29 November 2012 and Blenheim on 30 November 2012, respectively). For my part, I tried to explain the research I have done in French archives in order to achieve a hypothesis about the origin of the Toi moko from Rouen. That was an opportunity to demonstrate to the audience how long the process took to find some information about the donor, trader or acquirer in France.

\section{Semi-structured Interviews}

To complete this research employing a social sciences framework, interviews were undertaken in order to understand the different perspectives held on this controversial topic. The semi-structured interviews were a useful way to conduct interviews by allowing the opportunity to select the topic to be discussed and to prepare for the interviewee before the appointment. Additionally, qualitative interviews helped me to expand my understanding of each step of the negotiation and the several dimensions, such as geographical or professional, that can be involved in this process. Herein lies one dilemma which characterises this repatriation practice. The repatriation, and its negotiation beforehand, involved several actors from different backgrounds. For this reason probabilities around the accomplishment of such 
a return are based on many factors, including the context and participants involved. Because most of the repatriation of Toi moko from France back to New Zealand has already occurred, it was necessary to interview some of those involved in the repatriation, in a variety of ways.

Four of the interviewees who were intimately involved in repatriation were French and four were New Zealanders. I tried to embody all of the process of negotiation and the different issues met by those officers in France or New Zealand in these interviews. Because of the multidimensional nature of the negotiations, and with regard to obtaining examples of the different or common issues in countries, it was necessary to classify each interviewee into a professional category (curator, repatriation researcher, anthropologist, professor, director of museum, manager of repatriation programme, kaihautū or Māori leader of Te Papa and finally senator). Because this study is not focused on the legal environment in French law, I chose not to interview any jurists or legal researchers. Ethics approval was granted for this research (\#26851) by Victoria University of Wellington's Human Ethics Committee. Soon after each interview, I wrote complete transcripts in English and French and sent a copy of selected quotes to the participant. Afterwards, I gave each interviewee two weeks to review the transcripts in order to amend their own statements if they wished to. At the end of these two weeks, I considered that respondents gave me their approval for each statement I wanted to use in the text of the thesis.

These interviews are structured around questions which focused on how participants felt during the period of negotiation and their personal expectations on the collaboration postrepatriation. Throughout the discussions, I encouraged interviewees to explain their views on the role of the museum in this process. I asked all participants to talk about their own 
experiences in the discussion about the repatriation of Toi moko and how their relationships with their international interlocutors have evolved so far.

The interviewees were as follows:

- Sébastien Minchin, former director of the Museum of Rouen. He was in 2007, the first director of a French museum to open the discussion on the repatriation of the Toi moko in the collection of the Museum of Rouen.

- Catherine Morin Desailly, Senator of Normandy. She was the senator who led the law proposal at the senate in 2010 . She was also involved in the negotiation by representing the Museum of Rouen.

- Roger Boulay, an anthropologist who found the Toi moko in the Museum of Rouen's storehouse. He advised Sebastien Minchin to contact Te Papa on this issue.

- Michel Van Praët, emeritus professor at the MNHN. He is a museologist, whose research focuses on the evolution of museums and the exhibition of natural sciences and particularly the exhibition and preservation of human remains.

- Arapata Hakiwai, Kaihautū Te Papa. As a repatriation practitioner at Te Papa, Arapata observed all the stages of the negotiation. He maintains relationships with MQB-JC and other French museums after repatriation.

- Te Herekiekie Herewini, Manager of the KARP who has led the negotiation with French institutions since 2007.

- Coralie O’Hara, repatriation coordinator and researcher at Auckland War Memorial Museum. A former intern at KARP, Coralie is now involved in the repatriation programme at the Auckland museum. I wanted to learn her perspective on the organisation of repatriation in New Zealand and its involvement with the museum.

- Puawai Cairns, Te Papa's Head of Mātauranga Māori. She has been involved in several post-repatriation projects in France, including at Rouen and Paris. I wanted to learn from her how repatriation helped create relationships.

\section{Kaupapa Māori}

The place of kaupapa Māori (Mead 2003; Herewiniand Jones 2016) in KARP engagements is undeniable. The subject of human remains in museum collections and their repatriation is 
sensitive and has highlighted some Māori beliefs concerning ancestors and ideas about death both physically and spiritually. From a French perspective, it is a political dimension that is more closely associated with this repatriation operation than cultural consensus. Some French curators have doubts about the real cultural legacy of these ancestral remains and the effects of these repatriations on New Zealand soil. For this reason, I had to increase my knowledge about mātauranga Māori or Māori knowledge (Royal 2004, 2) through my fieldwork at Te Papa. It is necessary here to explain that this knowledge came from different interviews with people who had links with the museum environment or directly with the repatriation programme. My knowledge and my report are, therefore, directly linked to the museum setting. There are no significant differences between participants in this project concerning the kaupapa and mātauranga Māori used in KARP (Royal 2006, 7). This thesis is not representative of a general Māori perspective but it is a presentation of how these concepts are used in the museum sector such as repatriation ceremonies and the cultural logistics surrounding this kind of programme. This research method acknowledges and encompasses Māori values such as mana, tapu and whakapapa even if these notions "will only be partly understood and never completely known by non-Māori” (Pope 2008, 70).

I placed some importance on introducing tikanga Māori as it is integral to the ways in which KARP works in New Zealand. I apply an indicative approach towards Māori principles, according to my observations during my time as an intern. That is why my intention in this research is not to analyse tikanga Māori itself but to let the reader understand the different key concepts that compose the system chosen by KARP. In this sense, I would like to clarify that my research has been based on a relativist methodology that might lead me to change my perspective during the research period. I learned much during my different internships at Te Papa and created strong relationships with Māori staff but it is important to state that my intention is not to educate people about tikanga as such. All these key concepts are developed by Māori academics in their written books and articles. The kaupapa Māori methodology is framing research by, with and for Māori (Smith 2012). Even if I am currently working on a Māori topic, I cannot establish my studies on concepts I understand only on the surface. However, I believe this methodology can be used in order to complete my thesis in a sensitive way, by respecting Māori culture and values but at the same time acknowledging that my foreigner's perspective is an important dimension to include in my theoretical approach.

Ki te wareware i a tātau tēnei tikanga a tātau, arā te tangi ki ō tātau tūpāpaku, kātahi tō tātau Māoritanga ka ngāro atu i te matā o te whenua ki 
te Pō, oti atu. If we forget our cultural practices, particularly those pertaining to the dead, then our very essence of our existence as Māori will be lost from the face of this earth, to the underworld forever. ${ }^{3}$

In order to understand the context of colonial historyin which French acquired Toi moko, I have had to undertake research into both Māori society in pre-European times and today. This has enabled me to understand the kaupapa used in museum practice, such as that at TP and in the creation of the repatriation programme. Mātauranga Māori is essential to understand the link between a living Māori community and their ancestors. Even though this term is a modern expression, it is defining a long history of tikanga and kaupapa about the tūpuna. Moreover, mātauranga Māori has influenced the collaboration between the Crown and Māori concerning the preservation of taonga and consequently the transmission of knowledge those taonga are carrying (McCarthy 2011, 104-110). The repatriation process is a sensitive topic but the different steps of the negotiation and the research into this process reveal much more than the common link with the ancestors according to the Māori perspective. They also demonstrate connections between several principles that surround repatriation (Hakiwai 2014; Herewini 2017; Aranui 2018).

During my internship, my first mission was to understand the tikanga concerning ancestors but also to understand the concept of repatriation as a museum practice using traditional beliefs and schemes (KARP Pānui 2010a; Royal 2004). One of the first references on tikanga was by Hirini Moko Mead and his Tikanga Māori (2003). This book influenced my understanding of tikanga and how it could be expressed in everyday life. The repatriation procedure is not an ancient ceremony but draws its inspiration from tangihanga (funeral ceremonies) and other influences that characterise human remains such as tapu, whakapapa, wairua and the location where the ceremony can be organised - the marae. Situated in the post-colonial period, the repatriation practice promotes the Māori perspective internationally and enables it to be described by Māori themselves. Linda Tuhiwai Smith is one of these people. By decolonising methodologies, she describes the balance of power still active today

\footnotetext{
${ }^{3}$ Timoti Karetu in Rawinia Higgins, 2011, 'Tangihanga-death customs- tangihanga in modern times', Te Ara the Encyclopedia of New Zealand, http://www.TeAra.govt.nz/en/tangihanga-death-customs/page-5 (accessed 16 April 2014).
} 
between Māori and Pākehā perspectives on socio-political issues and on issues linked to the Māori world.

Starting to look at ourselves, but with new eyes, different eyes, thinking about ourselves not in a negative and not even in a grievance mode of being a colonised people but how do we think about ourselves, as sovereign people, as people who have a History, who valued knowledge and who have a future and wanted to find that future. How do we begin to reframe ourselves as self-defining people? (Tuhiwai Smith, Conference in New York, $\left.201333^{\prime} \mathrm{min}\right)^{4}$

As a French student and the first international intern integrated within KARP in 2009, my understanding of tikanga evolved by gradually learning more but also by changing my own attitudes over time. My personal and professional involvement within KARP and Te Papa activities gave me the chance to shape my perspective on repatriation in general. My learning in New Zealand was and still is dependent on the evolution of my personal approach to international relationships. In order to get a global definition of what a Toi moko is, research and personal involvement in meetings, ceremonies and workshops helped me to understand the international dimension of whakapapa and how it could be expressed in many different situations. That is the reason why it is important to get more data about the influences of the historical and cultural past of Māori culture and tikanga related to the repatriation process (Barlow 2001; Belich 2001; Davidson 1984; Edward, 1927; Hīroa 1966; Le Cam 1992; Makereti 1986; Mead, 2003; O’Reagan 2001). I have also been interested in the publications produced by Elsdon Best at the beginning of the $20^{\text {th }}$ century to understand its contemporary impact on Māori studies (1900, 1924, 1934, 1941, 1976, 1972, and 2001).

As well as delving into tikanga, my research delves into the process of pakipaki māhunga (process of preserving heads) or the practice of tā moko and their influence on the context of Toi moko acquisition by Europeans in the $19^{\text {th }}$ century (Best 1904; Cowan 1921; King 1972; Phillips 1948; Robley 2003; Roth 1901; Simmons 1986).Accordingly, the work of contemporary researchers on the description of tā moko practice and its effects on research into the Toi moko's origin appear in my thesis (Forbes and Hoult 2012; Gallagher 2003; Hatfield and Steur 2002; Louisson 1997; Te Awekotuku 2003, 2007; Higgins 2004). I wanted

\footnotetext{
${ }^{4}$ Tuhiwai-Smith L. Lecture on "Decolonizing methodologies" at CUNY (Graduate Center of New York), 2:03:50. video accessed 18 June 2018: https://www.youtube.com/watch?v=rIZXQC27tvg
} 
to understand the values of the practice of tā moko and its effects on the research into these human remains: How tā moko could be useful for KARP and how to collaborate with tattooists and particularly tohunga tā moko. Because tā moko is still relevant to understand the method of drying heads and is still peculiar to Māori tribes, I wanted to get more of an understanding of its implication in the repatriation process and, largely, its effects on New Zealand society (Te Awekotuku 2007, 2003; Mead 2003).

To understand the repatriation claims, it is important to appreciate how the legacy of iwi, hapu and whānau operates inside the process of research of the origin of the tūpuna. Also, KARP's newsletters $(2009 ; 2010 a ; 2010 b)$ point out that Te Papa respects the protocol of tangihanga during a repatriation ceremony. Hence, my reading about tangihanga (Higgins 2011, Te Awekotuku 2013) and its processes provides more information about the interest in repatriation, whether nationally through ceremonies held at Te Papa or locally when they occur on the marae of an iwi, hapū or whānau.

As Te Herekiekie Herewini noted earlier in 2017:

Māori are a contemporary people with a rich culture, tradition, philosophy, and language. In my view, the bridge that transfers and facilitates the integrity of past tradition to contemporary practice is tikanga Māori, which I have translated as "approved Māori cultural practice.” The contemporary domain of tikanga Māori is the marae (Māori tribal center), and tangihanga is the most common tradition that is actively practiced on marae throughout the country. The essential elements of the tangihanga include mutual honoring of tüpapaku (the deceased) and those who have gathered to pay their aroha (love and respect) through ritualized practices of playing taonga puoro (traditional Māori instruments), karanga (female call of acknowledgment), waerea (spiritual chants by males), whaikōrero (speeches of acknowledgment), mōteatea (Māori poetry in chant form), koha (gifts), hongi (pressing the nose), pō whakangāhau (farewell night of entertainment), and partaking in a hakari (feast) after burial. (Herewini 2017)

Although the tangihanga is carried out by all iwi groups in New Zealand, the protocols can change according to each iwi's perspective. That is why the descriptions of marae values and protocols are also interesting to study (Tauroa 1986 and 2005; Tapsell 2002; Gagné 2012; 
Jean 2013) in order to describe the Māori kaupapa related to the repatriation of taonga tuku iho as well as human remains (McCarthy 2005, 2011; Hardwood 2014; Maguire 2014). In order to fully understand the reasons for such repatriation operations in New Zealand, it is necessary to align the political context and the cultural and spiritual values embodied in Māori ancestors.

\section{Chapter outline}

This thesis comprises three parts, historical research or the research context, the current practice of repatriation, and an analysis and discussion of both. The Introduction, chapters One and Two provide the question, theory, methods, contextual background, and the history of acquisition of human remains during the first contacts between France and New Zealand. This historical analysis backgrounds the global definition of Toi moko at the time of their return to their land of origin. The analysis of the historical trade of Toi moko illustrates the involvement of the French explorers, naturalists and settlers in the colonial past and the consequence of trade in the socio-political organisation of each territory.

The second part explains how the process of repatriation is engaged in each country and how it has framed new types of relationships between French and New Zealand museums. This part focuses on the application of theory to practice including the repatriation process itself. Chapter Three provides information on the creation of KARP and the repatriation policy as it is applied in New Zealand today. This chapter also describes local missions organised by KARP such as hui ā rohe, and my participation in some of these presentations. Chapter Four analyses and discusses the process which occurred in France after repatriation claims. Here, the focus is on the one French museum that first contacted Te Papa in order to learn more about the process of repatriation.

Finally, the third part, Chapter Five, examines several questions raised during my study of the repatriation process, from my first internship in 2009 until today. The thematic analysis provides readers with a deeper understanding of the levels of debate and opposition that characterised the returns. The Conclusion summarises the research findings and my argument about repatriation as a postcolonial museum practice; discusses various limitations and possible further research; and puts forward several post-repatriation recommendations and suggests opportunities for future research and practice. 


\section{Part I}

An assemblage of knowledge

ignited by the repatriation process 


\section{Chapter One}

\section{First encounters:}

\section{The role of Toi moko in the colonial past of France and New Zealand}

\section{Introduction}

The repatriation process examined in this thesis is often presented, as we saw in the literature review, as a process of recognition. This recognition of the role of Toi moko in the colonial past shared between France and New Zealand, but also the recognition that they are a part of Indigenous heritage, can be documented through an analysis of the historical trade in Toi moko, the objective of this chapter. What we call today 'the duty of memory' (Butts 2002; Alivizatou 2012; Crooke 2015; Roustan 2016) is the main reason why repatriation practitioners in recent years, in both France and New Zealand, have been trying to find out as much as they can in a short time about the heritage of human remains. This attempt to recognise Indigenous heritage is reflected in the first instance by giving those human remains Māori names, Toi moko or mokamokai The contact made by French museums with KARP was the first step in understanding and acknowledging contemporary Māori perspectives on the past and the continuous heritage connections of Māori with their ancestral remains. When the Māori concept of whakapapa was acknowledged, Toi moko became symbols of the timeless significance of oral heritage and the recognition of cultural heritage on an everyday basis.

In addressing the research question, therefore, this chapter presents the role of Toi moko in the construction of Western imagery about Indigenous cultural identity and the reasons for the emergence of the trade for both parties. This chapter is also an opportunity to show how Toi moko figured as symbols of recognition of Indigenous tangible and intangible heritage and their part in the historical heritage of the colonial past. How did contemporary repatriation help museum professionals and government officials gain an understanding of Toi moko's historical heritage? How can research on the complex history of the acquisition of Toi moko help us to understand French colonial strategies in relation to New Zealand and their relationship with iwi Māori in the $19^{\text {th }}$ century? How does the history of repatriation affect the current practice of repatriation? 
The repatriation operation, as this chapter shows, reflects the entire history of those Toi moko, from their original significance in Māori communities in Aotearoa New Zealand through to their acquisition and collection by French institutions and subsequent (mis)representation in European imagery and exhibitions in French museums and galleries. This chapter is then divided into two main parts: the trade and its background including the French vessels which arrived on New Zealand shores in the first three decades of the $19^{\text {th }}$ century. This research into historical archival sources provides greater understanding of the social context in which the trade occurred and the first French testimonies on Māori cultural identity practised through the method of preserving and tā moko. French museums collected, exhibited or preserved Toi moko according to the scant information found in their archives and acquisition records. That information was mostly based on European imagery about Māori cultural identity. These remains were mainly stored in back-of-house collection areas and curators, researchers and senators obtained additional information thanks to the research carried out by KARP. In presenting the findings of the extensive historical archival research conducted for this study, this chapter therefore provides an understanding of Toi moko and insights into the colonial context of their acquisition at the beginning of the $19^{\text {th }}$ century, which in turn has shaped contemporary museum repatriation practice.

\subsection{The Trade in Toi Moko}

The first written source of information about the Toi moko trade comes from the testimony of Joseph Banks who participated in the first expedition to New Zealand commanded by James Cook in 1769. Banks negotiated with a man in Queen Charlotte Sound to acquire the head of a young boy killed in battle.

The first records regarding the trade in Toi moko present Te Waipounamu or the South Island as a place where the first trade occurred, it was at the opposite end of New Zealand at the Bay of Islands that the extensive trade of heads for muskets and vice versa took place from the early 1800s. Kāpiti like the Bay of Islands was also engaged heavily in the trade from the latter half of the 1820s. (Aranui 2011, 1)

The Bay of Islands is a coastal area of Te Tai Tokerau/Northland. Its strategic locality led to the arrival of growing numbers of Western explorers, whalers, settlers, and traders in the early 1800s. The bay became, therefore, a crucial commercial port for trade between French and Māori during those first years of encounters (Dunmore 1992; Proust de la Gironiere 2002; 
Poirier 2003; Sinsoilliez 2005). Several Māori tribes settled in Northland but Ngā Puhi is the tribe that appears most frequently in the journals of French explorers (De Freycinet 1837; Lesson 1839; Dumont d'Urville 1840; Laplace 1853). The development of the trade in Toi moko enabled Ngā Puhi to gain muskets and gunpowder in order to protect their pā and undertake raids in other territories (Ballara 2003). During those raids, Ngā Puhi were able to obtain more heads to fulfil this exchange with European-vessels. As demonstrated by the migration of Ngāti Toarangatira (Ngāti Toa) to Kāpiti Island, the crucial territorial position of some tribes engendered more opportunities to sustain exchanges with Europeans including the trade in Toi moko (Crosby 1999; Ballara 2003). Ngā Puhi is not the only tribe that played a role in this commercial exchange. Ngā Puhi at the Bay of Islands or Ngāti Toa at Kāpiti Island are both eminent tribes that played crucial roles in the development of trade nationwide (Aranui 2011; Herewini,Jones 2016).

In the South Pacific region, the British Empire first acquired territory in Australia and more precisely in New South Wales. Located on the east coast of Australia, this region became strategic for the British colonisation project in this part of the world. Thanks to its establishment at the city of Sydney and its harbour, Port Jackson, the British colony of New South Wales had a direct connection with New Zealand and had a significant role in the trade of Māori human remains (Turnbull 2018, 175; Aranui 2018, 40). This connection was so important that the governor of New South Wales was also nominated by the Crown as the authority on economic exchanges and the British settlement project in New Zealand (Maning 1863, Smith 1910). Several Māori chiefs visited this port throughout the first decades of the $19^{\text {th }}$ century in order to trade (Maning 1863, Hole 2007). Port Jackson became, consequently, a place where the trade in Māori heads emerged. Writing in the Sydney Sun, Thomas Dunbabin describes a trade in Toi moko that occurred in Sydney in 1814 when William Tucker attempted to sell one Toi moko that he stole in Foveaux Strait during his previous journey in 1811 (Wilkes 2013, 167).

It was, in fact, a Maori head, a fine specimen of the tattooist's art, carefully smoke-dried and preserved. Art collectors were rare in the Sydney of that day but such a work was bound to attract respectful attention. If local patrons failed, there was a market overseas for such a treasure. So Wioree benefited by(from) his enterprise to the extent of $£ 20$, which gave a very fair profit on the few shillings' worth of old iron which he had laid out for the head in New Zealand. (Dunbabin 1923, paragraphs 1 and 2) 
The possession of Māori heads by European sailors, amongst other artefacts, was profitable and a source of information concerning the communities of origin. Europeans had a different attitude towards human remains, but despite those differences, they rapidly understood the value of these heads for Māori. Cultural and scientific institutions throughout Europe used explorers' or naturalists' testimonies to generate their own observations and conclusions on each element-bought and donated. Sailors, simultaneously, were more concerned about the commercial value and were attentive to the prices that Toi moko reached on the European art market (Lesson and Garnot 1839, 280; Sinsoilliez 2005, 72).

The study of the conversion of Toi moko, which moved from funeral commemoration into commercial object and curiosities, provides an opportunity to develop an in-depth understanding of colonial expansion in the 19th century. The European presence in the country dramatically changed New Zealand's natural and cultural environments. The arrival of more settlers from every part of Europe and particularly from the United Kingdom created sweeping changes in Māori society. For European settlers, New Zealand was another chance to start a new life, through acquiring land to establish farms or private properties (Sinsoilliez $2005,78)$.

In 1805, the Bay of Islands was the area where unprecedented commercial activity developed. The main European motivation for the acquisition of human remains and especially Toi moko was commercial profit (O’Hara 2012, 15). Obtaining human remains was perceived as proof of encounter with Indigenous people and nourished European curiosity towards Māori. For example, René Primevère Lesson and Jules Sébastien Dumont d'Urville collected Toi moko in order to donate them to scientific institutions or simply sell them in France. Toi moko were thus an element in the market of curiosities throughout Western countries, including Horatio Robley and Joseph Banks from England (King 1981, 91; Hole 2007, 11-12)but also French explorers as the research through the repatriation negotiations has showed (Jean 2020, 428). .

Commercial profit and racist classification underpinned the trade of Toi moko during the first encounters. In the late $19^{\text {th }}$ century, an additional motivation encouraged Western scientists to acquire human remains when they, along with collectors, were persuaded to believe that the Indigenous population of New Zealand was in peril and threatened with extinction (Walker 2004, 172; Hole 2007, 11). Wars but also diseases, and the actions of expansive colonialism had caused a significant demographic decline within the Māori population. Because of a view of eventual disappearance of Māori and the desire to uphold their folkloric, Western 
conception of Māori tribal identity, several scientistsconsidered these collections and their possession to be a "rescue operation in the name of science" (Hole 2007, 7).

Only 70 years passed between James Cook's arrival and the Treaty of Waitangi and during this time Europeans became present in every region of New Zealand. Māori were still in favour of trade and commercial transactions with newcomers, a situation that proves the existence of a significant collaboration to the benefit of both sides. Māori exchanged Toi moko and other taonga in order to acquire products manufactured in Europe.

On the other side, Europeans exchanged axes, needles, blankets and hammers but also muskets, gunpowder and alcohol in exchange for Māori supplies. Europeans were able to establish themselves rapidly thanks to Māori sharing their comprehensive Indigenous knowledge of the natural environment in which they were settling (Belich 2006). Colonial authorities demonstrated rapidly a desire to control the territory through land occupations by transactions or spoliations. At the same time, contact between French and Māori increased. French whalers, in addition to the few French scientific expeditions, sailed to New Zealand to sustain the whale oil market in Europe (Poirier 2003, Sinsoilliez 2005). There are big assumptions about the participation of French whalers in the trade of Toi moko. Explorers and writers in other journals of circumnavigation refer to whalers (Dumont d'Urville 1835, Laplace 1853, Lesson 1839, Bougainville 1837) and their increasing presence on New Zealand shores from the 1820 's which supports the theory of their participation in the trade. .

\subsubsection{The Musket Wars or the historical context of the trade in Toi moko}

The name Musket Wars describes a new type of conflict enabled by the firepower imported by not just by explorers and settlers but also include whalers, sealers and flax traders. This inter-tribal conflict based on economic, political and territorial interests took place intermittently between 1806 and 1845, according to the historian R. D. Crosby (Crosby 1999). This period of first contacts between Europeans and Māori transformed Indigenous cultural identity and created an imbalance of power that still today shapes the relationship between Māori and the Crown. However, the image of ongoing conflict served to support the European 
so-called scientific classification of people based on the dimension of 'civilisation' observed in each community.

As Ranginui Walker has argued:

While the Musket Wars were debilitating, conversion to Christianity led to further erosion of Māori culture and power. The missionaries condemned polygamy, slavery, the tohunga and tapu, the institutions that buttressed social control and the power of chiefs. (Walker 2004, 85)

In her book Taua, Angela Ballara (2003) questions the validity of the term 'Musket Wars'. She points out that the musket can be seen as having contributed to Māori history rather than determining it. These wars were about tikanga (custom) and often involved the settling of old scores. Ballara argues that they would have occurred regardless - the musket was merely a new tool. The new technology made conflict more destructive but did not cause it.

Ballara and fellow historian James Belich point out that the musket contributed less to the bloodbaths of the early 19th century than the "humble spud, which created the food surpluses war parties (taua) needed to supplement captured supplies and human bodies”. As Gavin McLean points out, neither 'Potato Wars' nor 'Taua' stuck, so Musket Wars they became. (Ministry for Culture and Heritage, 'The Musket Wars', accessed 13 May 2018)

This key period in New Zealand history compounds conflicts among Māori with the developing Toi moko trade with settlers. Frederick Maning described the outcomes of the trade and the consequences of it among Māori in 1863:

This head, I found on inquiry, was not the head of an enemy. A small party of our friends had been surprised, and two brothers were flying for their lives down a hill-side; a shot broke the leg of one of them and he fell. The enemy were close at hand; already the exulting cry "Na! na! mate rawa!" was heard; and the wounded man cried to his brother, "Do not leave my head a plaything for the foe." There was no time for deliberation. The brother did not deliberate; a few slashes with the tomahawk saved his brother's head, and he escaped with it in his hand, dried it, and brought it 
home. The old woman was the mother, the young ones were cousins: there was no sister, as I heard, when I inquired. All the heads on the hill were heads of enemies, and several of them are now in museums in Europe.

With reference to the knowing remarks of the pakeha who accosted me on the hill on the state of the head market, I am bound to remark that my friend Mr. — never speculated in this "article;" but the skippers of many of the colonial trading schooners were always ready to deal with a man who had "a real good head," and used to commission such men as my companion of the morning to "pick up heads" for them. It is a positive fact that some time after this the head of a live man was sold and paid for beforehand, and afterwards honestly delivered "as per agreement. (Maning 1863, 59)

The consequences of the Musket Wars on Māori society were deplorable. "Tens of thousands of Māori were killed, injured or displaced during these discontinuous clashes between 1806 and 1845" (Crosby 1999, 35). In the introduction he wrote for Crosby's book, Michael King adds that the use of muskets also had consequences on population movement throughout the territory when iwi could force other groups away from their original lands by the use of greater firepower (King in Crosby 1999, 11).

Finally, the Musket Wars ended with a new rivalry between Māori and European settlers (Belich 1986, Ballara 2003). Māori groups located in coastal areas like Bay of Islands firstly sustained the trade of Toi moko in exchange for European firearms, muskets, and gunpowder. Over time, this trade involved all tribal groups throughout the territory of both Te Ika a Māui (North Island) and Te Wai Pounamu (South Island of New Zealand).

\subsection{French presence in New Zealand at the time of the trade}

Two events occurred at the end of the $18^{\text {th }}$ century that influenced the French representation of Māori communities. First, in 1772, the French captain Marion du Fresne was killed and eaten during a confrontation with Māori. During this conflict approximately 38 members of the French expedition were killed and up to 250 Māori fell under French firepower (O’Halloran 1939). Captain Cyrille Pierre Théodore Laplace was commander of La Favorite in September 1831 when he stayed 10 days at the Bay of Islands (Dunmore 1991, 155). When he returned to New Zealand eight years later aboard the Artémise, he wrote in his journal that 
he had no intention to stay again in the bay because of the murder of Marion du Fresne (Laplace 1853, 352).

The second event was the loss of the vessels Astrolabe and Boussole commanded by JeanFrancois de La Pérouse in the 1780s. La Pérouse had been commissioned by King Louis XVI to explore the unknown territories of Oceania. In 1788, after three years at sea, the two ships and their crews disappeared in the South Pacific, having last sent letters from Botany Bay in Australia. Several expeditions were financed by France to investigate what happened to Marion du Fresne and La Pérouse in Pacific seas. Their disappearances strengthened the view in France that the Pacific Islands were inhabited by dangerous natives and postponed the colonisation of Polynesia by France until the 1820s (Sinsoilliez 2005).

At the same time, I believe that it is not wise for any ships masters or anyone from their crew to buy these heads; because if a tribe was aware that the head of one of its chief is aboard a ship, it would be very likely that the tribe would attack the ship to get it back, because of the esteem and the high veneration applied to these precious relics. (Domeny de Rienzi, 1856, 179)

Despite this negative reputation, most of the French expeditions in the Pacific during the early 19th century visited New Zealand providing the opportunity for explorers and scientists to recognise the value of Toi moko to Māori. Jules Sebastien Cesar Dumont d'Urville developed a humanist approach regarding Māori values and protocols such as the pakipaki māhunga and tā moko. Because of this interest, he kept coming back to visit the Bay of Islands and increase his knowledge about Māori cultural identity. He also understood the imbalance of the Toi moko trade and the different motivations behind it.

We understand what interest the Zealanders had in preparing and preserving them. There was no intention of trade; they acted like the ancient Egyptians, who pushed by a creditor, gave the body of one of their parents as one last guarantee [...] Since Cook, no scientific expedition had had contact with New Zealanders, for nearly fifty years; but at the beginning of this century, whalers and sealers saw in these smoked heads a new commodity with an advantageous debit. (Dumont d'Urville 1835-1836, 366)

Ships on exploration expeditions were not the only type of vessels that stopped in New Zealand or Port Jackson (Sydney). Hundreds of whaling ships from Europe and America also 
went to the South Pacific. The presence of whalers was another way to explore and colonise those islands. Governments sent whalers not only for hunting but also for expanding their colonial territories (Proust de la Gironière 2002, Poirier 2003). In 1838, Jean Francois Langlois, commander of the whaler Cachalot attempted to create a French colony at Banks Peninsula. Supported by King Louis Phillippe, Langlois purchased land at Akaroa in order to settle. In 1840, an expedition was ordered by the French government to colonise Te Waipounamu, the South Island of New Zealand. Along with their primary mission to hunt whales, the Aube and the Comte of Paris were to transport French colonists to Akaroa (Tremewan 1990, Poirier 2003, Sinsoilliez 2005). By means of this strategy, France wanted to compete with the British settlement that was growing thanks to Captain Hobson (Sinsoilliez 2005, 84; Proust de la Gironière 2002, 35) who, upon his arrival at the Bay of Islands on 29 January 1840, attempted to persuade the Māori chiefs to recognise British sovereignty over the entire territory (Poirier 2003, 113). As soon as the Uranie arrived in Port Jackson in 1819, its captain Louis de Freycinet noted the influence the British had in commercial activity with Māori, describing in his journal, published in 1837, that British colonial expansion threatened any French monopoly on trade by attracting many English ships to New Zealand:

Thus, without adding further authority over the naturals other than what the New Zealanders have kindly agreed to abandon, and without intervening in the internal government of the country other than by persuasion and in the form of opinions, the English pride themselves that the influence of one resident of their nation will be sufficient to force the naturals to abandon their odious practices of war and massacres; that this influence, combined with the efforts of their missionaries and the civilizing power of trade, will eventually substitute principles of gentleness and habits of a civilized people for the fierce mores of these cannibals. This is how they skilfully and consistently plan to ensure, if not absolutely the monopoly of an immense trade, at least a marked preponderance, that promises them immense benefits for the future! (De Freycinet 1837, 915-916).

This competition between two of the largest Western colonial empires for the occupation of territories is an example of the tensions that existed between France and England at the beginning of the $19^{\text {th }}$ century. For fear of seeing the whole Pacific under British authority, the French rapidly reached New Caledonia and other islands consequently named French Polynesia. Settled in Akaroa, located at the end of the Banks Peninsula, several French people 
decided to stay even though England became the main European colonial power on these lands.

Several Toi moko, formerly kept in French collections and returned to New Zealand between 2010 and 2012, were obtained by commercial transactions during the 19th century. Many of these heads were donated to institutions by the captains, naturalists, or scientists from ships, such as Uranie (1817-1820), Coquille (1822-1825), Thétis (1824-1826), and Astrolabe and Boussole (1826-1829). These ships had stopped in various ports where traffic of Toi moko occurred. For example, the Uranie in 1819 and probably the Thétis in 1824, anchored in the Bay of Islands, which was also visited by the Coquille in 1824 and by Astrolabe in 1827. In New Zealand, the trade of Toi moko mostly occurred at the Bay of Islands and Kāpiti Island (Panui 1, 2009). Yet, the trade of Toi moko occurred in many others places than New Zealand shores. Places like Mauritius, Port Jackson and Hobart town(Aranui 2018b, 1). From the first meeting between the French and Māori, the Europeans planned to bargain with and make the first scientific observations of the regions with a view to dominating them in the near future. Indeed, the correlation of the missionaries' imprint, in the image of Bishop Pompallier, with the first commercial activities undertaken around 1820 proves France's colonial interest in this region of the world. Jean François de Surville aboard the Saint Jean Baptiste was the first French captain to meet Māori in 1769 in order to trade and have the opportunity to "observe the natives in their environment" (Dunmore 1969, 1992).

Table 1: Toi moko acquisitions by French explorers 1769-1846: ${ }^{5}$

\begin{tabular}{|l|l|l|l|l|}
\hline $\begin{array}{l}\text { Name of } \\
\text { Ships }\end{array}$ & $\begin{array}{l}\text { Shipping } \\
\text { Time (arrival } \\
\text { in NZ) }\end{array}$ & $\begin{array}{l}\text { Name of Captains } \\
\text { and/or naturalists }\end{array}$ & $\begin{array}{l}\text { Sites visited in New } \\
\text { Zealand }\end{array}$ & $\begin{array}{l}\text { Toi moko trade and } \\
\text { colonisation attempt }\end{array}$ \\
\hline $\begin{array}{l}\text { Saint Jean } \\
\text { Baptiste }\end{array}$ & $\begin{array}{l}\text { 1769-1773 } \\
(1769)\end{array}$ & $\begin{array}{l}\text { Jean François de } \\
\text { Surville }\end{array}$ & Hokianga-Doubtless Bay & $\begin{array}{l}\text { No Toi moko. Ranginui } \\
\text { (Ngāti Kahu) was } \\
\text { aboard to go to Europe } \\
\text { but died during the trip. }\end{array}$ \\
\hline $\begin{array}{l}\text { Mascarin }- \\
\begin{array}{l}\text { Marquis de } \\
\text { Castries }\end{array}\end{array}$ & $\begin{array}{l}1771-1772 \\
(1772)\end{array}$ & $\begin{array}{l}\text { Marc Joseph } \\
\text { Marion du Fresne. }\end{array}$ & $\begin{array}{l}\text { Taranaki-Bay of Islands } \\
\text { (Death of the Captain and } \\
\text { 26 sailors.) }\end{array}$ & \\
\hline $\begin{array}{l}\text { Espérance } \\
\text { and } \\
\text { Recherche }\end{array}$ & $\begin{array}{l}1791-1794 \\
(1793)\end{array}$ & Bruny & D'entrecasteaux & $\begin{array}{l}\text { North Coast of North } \\
\text { Island }\end{array}$ \\
\hline
\end{tabular}

\footnotetext{
${ }^{5}$ Information found in Logbooks and Museum donation books appeared on the press release from the repatriation ceremony at MQB-JC on 23 January 2012.
} 


\begin{tabular}{|c|c|c|c|c|}
\hline Uranie & $\begin{array}{l}\text { 1817-1820 } \\
\text { (Sydney } \\
\text { December } \\
\text { 1819) }\end{array}$ & Louis de Freycinet & $\begin{array}{l}\text { Bay of Islands } \\
\text { (Toi moko acquired in } \\
\text { Port Jackson where } \\
\text { Uranie stayed } 5 \text { weeks } \\
\text { between November and } \\
\text { December 1819.) }\end{array}$ & $\begin{array}{l}\text { Three Toi moko at least. } \\
\text { One was given to the } \\
\text { MNHN }\end{array}$ \\
\hline Coquille & $\begin{array}{l}1822-1825 \\
(1824)\end{array}$ & $\begin{array}{l}\text { Louis Isidore } \\
\text { Duperrey } \\
\text { (Captain)-J.S. } \\
\text { Dumont d'Urville } \\
\text { (Second } \\
\text { commander)-R.P. } \\
\text { Lesson (second } \\
\text { surgeon and } \\
\text { taxidermist) } \\
\end{array}$ & Bay of Islands & $\begin{array}{l}\text { Five Toi moko. three by } \\
\text { R.P. Lesson, who } \\
\text { donated } 1 \text { to the } \\
\text { MNHN, One in } \\
\text { Rochefort and } 1 \text { to a } \\
\text { private collector. } \\
\text { The captain also had at } \\
\text { least two in his } \\
\text { possession. }\end{array}$ \\
\hline $\begin{array}{l}\text { Thétis and } \\
\text { Espérance }\end{array}$ & $\begin{array}{l}1824-1826 \\
(1824)\end{array}$ & $\begin{array}{l}\text { Hyacinthe de } \\
\text { Bougainville }\end{array}$ & $\begin{array}{l}\text { Port Jackson where one } \\
\text { Toi moko may have been } \\
\text { traded (maybe more.) }\end{array}$ & $\begin{array}{l}\text { One was donated to the } \\
\text { Natural History } \\
\text { Museum of Nantes in } \\
1826 .\end{array}$ \\
\hline Astrolabe & $\begin{array}{l}1826-1829 \\
(1827)\end{array}$ & $\begin{array}{l}\text { Jules Sébastien } \\
\text { César Dumont } \\
\text { d’Urville }\end{array}$ & $\begin{array}{l}\text { Westcoast of South } \\
\text { Island- Grey River- } \\
\text { Tasman Bay-Cook Strait- } \\
\text { French Pass-East Coast of } \\
\text { North Island-Tolaga Bay- } \\
\text { Bay of Plenty-Whangarei- } \\
\text { Hauraki }\end{array}$ & $\begin{array}{l}\text { Two or three Toi moko. } \\
\text { One by Dumont } \\
\text { d'Urville. One by P.A. } \\
\text { Lesson (R.P. Lesson's } \\
\text { older brother). } \\
\text { Both were traded at the } \\
\text { Bay of Islands. One Toi } \\
\text { moko was donated to } \\
\text { the Museum of Sens } \\
\text { with a mention of its } \\
\text { acquisition during the } \\
\text { Astrolabe } \\
\text { circumnavigation. } \\
\text { Further research has to } \\
\text { be undertaken on this } \\
\text { point. }\end{array}$ \\
\hline Favorite & $\begin{array}{l}1829-1832 \\
(1831)\end{array}$ & $\begin{array}{l}\text { Cyrille-Pierre } \\
\text { Theodore Laplace }\end{array}$ & $\begin{array}{l}\text { Kawakawa River-Bay of } \\
\text { Islands }\end{array}$ & \\
\hline Héroïne & $\begin{array}{l}1837-1839 \\
(1837)\end{array}$ & $\begin{array}{l}\text { Jean Baptiste } \\
\text { Cécille }\end{array}$ & $\begin{array}{l}\text { Bay of Islands-Chatham } \\
\text { Islands }\end{array}$ & $\begin{array}{l}\text { Taonga collection } \\
\text { gathered after burning a } \\
\text { village at Chatham } \\
\text { Islands (Ngāti } \\
\text { Mutunga). }\end{array}$ \\
\hline Venus & $\begin{array}{l}1836-1839 \\
(1838)\end{array}$ & $\begin{array}{l}\text { Abel Aubert du } \\
\text { Petit-Thouars }\end{array}$ & Bay of Islands & \\
\hline $\begin{array}{l}\text { Astrolabe- } \\
\text { Zélée. }\end{array}$ & $\begin{array}{l}1837-1840 \\
(1840)\end{array}$ & $\begin{array}{l}\text { Jules Sébastien } \\
\text { César Dumont } \\
\text { d'Urville }\end{array}$ & $\begin{array}{l}\text { Auckland Islands-Otago } \\
\text { Bay and Bay of Islands. }\end{array}$ & \\
\hline Aube & 1840 & & $\begin{array}{l}\text { Bay of Islands and } \\
\text { Akaroa. }\end{array}$ & Colonisation attempt \\
\hline $\begin{array}{l}\text { Comte de } \\
\text { Paris }\end{array}$ & 1840 & & $\begin{array}{l}\text { Bay of Islands and } \\
\text { Akaroa }\end{array}$ & Colonisation attempt \\
\hline Rhin & $\begin{array}{l}1842-1846 \\
(1843-1846)\end{array}$ & & $\begin{array}{l}\text { Akaroa-Wellington- } \\
\text { Auckland-Bay of Islands- } \\
\text { Akaroa }\end{array}$ & $\begin{array}{l}\text { Studies of British } \\
\text { colonisation around } \\
\text { New Zealand. }\end{array}$ \\
\hline
\end{tabular}


This table shows the interest in Toi moko displayed by French captains and scientists since the first explorations of the South Pacific. I wanted to expand also on the different sites visited by these expeditions and the popularity of the trade early in the $19^{\text {th }}$ century. Furthermore, the trade of Toi moko mainly occurred in the northern region of the North Island and extended rapidly to different regions of New Zealand but also foreign localities like Port Jackson in Australia. The trade was not only profitable for sellers in New Zealand but everywhere that Toi moko could be located.

\subsubsection{The Uranie and Physicienne (1817-1820)}

By order of King Louis XVIII, the scientific expedition of the corvettes Uranie and Physicienne left Toulon on 17 September 1817 (Ferloni 2006, 76). Among other missions, this expedition conducted scientific experiments on the earth's magnetism (Humboldt et al $1821,4)$. It also attempted to gather as much information as possible on the disappearances of Marion du Fresne and La Pérouse. Louis de Freycinet was the captain and intended to meet with Māori chiefs to discover the circumstances of the death of Marion du Fresne in the Bay of Islands in 1772 (de Freycinet 1837a; Dunmore 1969). The two ships reached Port Jackson in November 1819 where they stayed for five weeks. They were surprised when they stopped in Sydney to meet Māori chiefs who had come especially from the Bay of Islands to trade with anchored boats. In his diary, de Freycinet remarks on the great interest shown by Māori in European items, and comments on the imbalance between English and Indigenous people:

Early on, governors of Port-Jackson assessed how important it would be for the colony that they administrate to develop trade relations with New Zealand; so they have not forgotten anything that might flatter the tastes or attract the attention of the male population that inhabits this archipelago. On several occasions some of their leaders came to Sydney and got a more advantageous idea of the intellectual and manufacturing superiority of the English, than they had been able to do until then in their relations with those of the navigators of this nation who, at various times, released in this part of the southern lands. Finally, journeys to England and London by these savages themselves have finished dazzling them and have given rise to a strong desire to own the goods and luxury items that for so long have aroused their desire. (de Freycinet 1837a, 308) 
After reading some parts of Joseph Banks' logbooks, de Freycinet became fascinated by the Māori art of tattooing. Even before seeing the coasts of New Zealand and still in Port Jackson, he was already in negotiations with Māori chiefs to purchase several Toi moko in exchange for gunpowder. He agreed to trade with them and obtained at least three different heads. De Freycinet recounts this event in his logbook:

During Uranie's stay in Port-Jackson, several New Zealand chiefs came to visit; we observed them with interest; and Mr. Pellion drew with his usual accuracy the faces of some of them, which can be found engraved under numbers 1, 2 and 3 on our plate 107. The drawings below them were done on dried heads, in New Zealand itself, and are singularly well preserved in terms of shape and detail. We bought these curiosities at Port-Jackson, from where they were transported to Paris and deposited at the Natural History Museum. The sketch of these last three heads should therefore only be considered as a study of these singular and complicated tattoos that the leaders of these warrior tribes do to themselves. It will undoubtedly be noticed that among them, some have frizzy hair and others are straight. The leaders of New Zealand, says Busby who provides us these details, are personally remarkable for a vigour of spirit and foresight that may distinguish them from all the other savages as underdeveloped as they are in the arts of Europe. Their discernment in appreciating the benefits of civilization is as great as their energy and the self-sacrifice they make to achieve its distant benefits are remarkable. (de Freycinet 1837, 909-910)

The acquisition of Toi moko by the captain enabled Pellion to draw their respective tattoo patterns in order to start a comparative study of Māori tattooing with other Polynesian communities. Unfortunately, Pellion made no mention of this meeting or the exact origin of the three heads in his journal. De Freycinet emphasises that none of the three names appearing at the bottom of plate 107 (Etu-Deni, Piro and Etu) are the names of the deceased. It is consequently still not possible to identify them through the information in these documents. These three heads were sent to the MNHN to complete the anthropological collections with 
the primary purpose of recognising the delicacy of tattoo art among the Māori of New Zealand.

\subsubsection{The Coquille (1822-1825)}

After leaving Toulon in August 1822, the Coquille arrived at the Bay of Islands on 3 April 1824. There, Captain Louis Isidore Duperrey was welcomed by one of the most well-known Māori chiefs who participated in the trade, Hongi Hika of Ngā Puhi. The officers on board had several opportunities to obtain Toi moko during their stay, and anticipated those opportunities prior to leaving Toulon by getting more muskets or gunpowder for bartering. This passage from the logbook written by the naturalist René Primevère Lesson supports the hypothesis that Toi moko were easily purchased in this Bay in 1824 and earlier:

As soon as they [Māori traders] saw that the purchase had slowed down, one of them pulled a man's head from under a mat, dried according to their methods, and by taking it by the hair, he showed it to us cheerfully, shaking it over his head. I bought it as an anatomical curiosity for a pound of [gun]powder, the only thing that was worthy to them and that we all had bought in Port Jackson. Other natives showed us more heads, and a woman had one hidden under her loincloth and played with it with an indifference that chilled us with horror. These heads...are those of warriors or leaders killed in battle, and those savages dry them up with great skill and keep them as trophies of their victories. It is now an important commercial element for them, to be sold to Europeans for powder. In addition, despite the fact that this shameful traffic, I will admit, is strictly prohibited by the administration in Sydney, all ships that go from New Zealand to New South Wales carry a large number of them, and in Port Jackson they are sold publicly for a maximum of 15 piasters. (Lesson 1939, 280)

He confirmed this statement later in his journal:

There, they only deal with agriculture, selling products to ships in port [...] It is even added that this smuggling that comes to Sydney includes all the tattooed heads that are sold there at a very high price, because they are paid from 15 to 20 piasters. (Lesson 1939, 341) 
As soon as he arrived in the Bay of Islands, René Primevère Lesson made no secret of his interest in acquiring a number of these heads to supply to museum and private collections on his return to France. From the second day of their stay in this bay, many waka came to meet them and Māori boarded the ship and offered him Toi moko in exchange of gunpowder:

I had taken good care to buy gunpowder in Toulon, so I was able to complete my collections of valuable objects for the Museum, especially as the demonstration of this powder enclosed in tin boxes had given the natives a strong idea of its force. Thus on this day [4 April 1824] I obtained three New Zealand heads preserved in the admirable method of these peoples, far superior to anything that Europeans had attempted in the field of mummification. One of these heads had been hidden under the skirt of a young girl and she held this hideous toy with complete indifference. She took it by the hair to demonstrate its soundness and turned it in all directions so that I could admire the regularity of its rich tattooing.

This removed head seemed to be the one of a man in sleep, because his relaxed and sewn closed eyelids, his mouth partially opened and dried out upon beautiful teeth, still seemed to be marked by the sardonic laughter of the warrior who braved his enemies and the death that was given to him. (Lesson 1839, 316-317)

He also gave information on the future location of the human remains when he returned to France. The high value of ancestral remains in France is demonstrated by the mention of two different cultural institutions and a private collector as recipients. "I gave one to the Museum [Paris], the second to the Rochefort anatomy office, and the third to a rich private collection". (Lesson 1839, 316)

The two Toi moko that have been donated to museums (Paris and Rochefort) were part of the repatriation in January 2012 at MQB-JC: one from the MNHN and the other one might have been returned by the Maritime Museum. Further research needs to be done on the third one. Maybe it was given later to another museum or it is still in one family's collection. No information has been given on the identity of this private collector. No more information has been accessed about this head, but it is likely that it remained in the care of the collector's 
family or was presented to an institution under another appellation. Other archives need to be studied in order to develop a research approach.

These three previous quotes show Lesson's interest in obtaining such treasures. He was already aware of their value before leaving from Toulon and purchased gunpowder. He wanted to obtain as many objects as he could in order to bring them back to France and add to museum collections.

Victor Charles Lottin, who was the cartographer of the expedition, gives further information on the specific demand for guns in exchange for Toi moko:

[The Māori] want powder and muskets and are not interested in anything else. However, they bring pigs, chickens, fish in large quantities, potatoes and sweet potatoes and curiosities such as various kinds of carpets, fishing lines, hooks, fetishes, adzes, patupatu and other jade ornaments, carved wooden flutes and human bones, shark teeth, dolphins, human bone hooks and forks, small carved boxes and, finally, several tattooed heads. A young slave boy was on board and his master wanted to sell him for a two-shot gun. (Lottin In Crosby 1999, 119)

At this time, the trade was probably carried out with discretion, it wasn't yet the popular exchange that it would become few years later. Lottin explains that Māori traders were keen to exchange them by exhibiting them freely. 'In this case they had stuck them on sticks and were playing with them as with the most indifferent of objects.' (Lottin In Crosby 1999, 119). Lieutenant Theodore Julien De Blois De La Calande recorded this growing commercial activity in this region of the Pacific as soon as The Coquille left the Bay of Islands on 17 April 1824:

During our stay in the Bay of Islands [...] we spent all our time recording the geography of the Bay of Islands and adding natural history specimens and local curiosities to our collections, such as preserved heads, weapons, mats, fetishes, etc. (Calande In Ollivier 1986, 14)

The Coquille transported the second French expedition for which there are records of Toi moko transactions in several reports associated with the Bay of Island or Port Jackson. These exchanges concern human remains and the discovery of customs such as pakipaki māhunga and tattooing. The logbooks are particularly detailed from a geographical perspective, but the 
scientists of the time were influenced by a distorted image of Māori communities. Their observations in situ reinforced this representation by emphasising the practices of pakipaki māhunga and tā moko which, at the time, were regarded to be heretical customs that colonisation would try to annihilate.

\subsubsection{The Thétis (1824-1826)}

The Thétis was commissioned to nurture commercial relationships in countries all over the globe including Brazil, the Canary Islands, Haïti and Australia. In August 1825, the Thétis anchored at Parramatta, on Australia's east coast. There, Captain Bougainville had the chance to meet Samuel Marsden with whom he discussed the Indigenous people of New Zealand. The Bougainville appears to have been already aware of the trade of Toi moko from New Zealand between sailors and Indigenous people and described the trade in his journal written 10 years after he returned to France:

They are cannibals, admittedly, but under religious principles; following as they say, the law of nature: fish eats fish, a bird makes other birds their prey; they are only eating their prisoners!...-The death found on the battlefield is preferable for these islanders to the death that old age brings. They cut the head of their dead fathers and mothers, embalm it, preserve it, and display it the same way as we are showing family portraits. - During our stay, a whaler, coming from those islands, brought several heads perfectly preserved, but I was not interested at all in acquiring some. Europeans initiate this idea of a new trade with these savages that costs the life of one of them every day; in vain, to stop those assassinations, the English government forbade, under the most severe punishments, to sell or buy those horrible remains. The lure of profit on one hand for some or the attraction of an awful and guilty curiosity for others on the other hand, are prevailing any other feelings, and there is no ship coming from New Zealand that doesn't have aboard a few embalmed heads. The most desired are those who have been tattooed and it costs between twenty and twenty five piasters: regularly those patterns are printed after the death, which makes them easier, as we say, to recognise; on all of them, hair or beard are perfectly preserved. (Bougainville 1837, 523-524) 
Despite Bougainville's statement that he did not acquire Toi moko, the Thétis brought at least one Toi moko to Nantes, the port from which the ship had set sail in 1824 . This city is also the birthplace of the chief surgeon of the expedition, Francois-Louis Busseuil (1791-1835) who donated one head to the Natural History Museum (Acquisition book of the museum of Nantes). Busseuil played a large part in the scientific research of the expedition, being in charge of medicine, meteorology and natural history and contributing extensively to the journal of the circumnavigation (Annales, Notices Necrologiques 1835, 111).

Unfortunately, no records of Busseuil's acquisition have been found, however it is feasible that he obtained this Toi moko during his stay at Parramatta in August 1825. His name appears in Paul Turnbull's Science, Museums and Collecting the Indigenous Dead in Colonial Australia in a section where Turnbull focuses on the epistolary relationships between Lancelot Threlkeld (of the London Missionary Society) and Saxe Bannister (New South Wales Attorney General). In those letters, the two men discuss the phrenological analysis of skulls and refer to the work of Francois Louis Busseuil carried out during his journey aboard the Thétis (Turnbull 2017, 186). In the first decades of the $19^{\text {th }}$ century, it was common for circumnavigations to gather all types of artefacts from different parts of the globe. The Thétis gathered artefacts especially for the National Museum of Natural History of Paris.

\subsubsection{The Astrolabe (1826-1829)}

Jules Sébastien Dumont d'Urville began his career as a specialist in botany and linguistics, but after graduating from Caen High School, he joined the navy. In 1807, he served on the Aquilon as a novice, then became an officer in 1809 and served on the Amazon. D'Urville was promoted to lieutenant in 1821 (Ferloni 2006). After his first circumnavigation expedition aboard the Coquille between 1822 and 1825, d'Urville planned his own voyage of exploration and he presented his project to the minister of marine affairs shortly after his return to France. His proposal was accepted before the end of the year, and he began preparing for this new trip. The ship chosen for this expedition was the Coquille, the corvette on which he had made his first round-the-world voyage under the command of Duperrey. The objective of this new expedition was the same as that of the earlier trip on the Coquille - to gather as much scientific data as possible on the lands encountered (Dunmore 1969, 1992; Ferloni 2006). In addition, the King had requested that d'Urville investigate the mysterious disappearance at sea of Captain La Pérouse in 1788. As a tribute to La Pérouse, d'Urville renamed the Coquille after the Astrolabe - one of the two ships that had gone missing under the command of La 
Pérouse. The Astrolabe left Toulon on 25 April 1826 and on 7 October reached Australia anchoring first at King George Sound then at Port Jackson where the ship remained until 19 December (Dumont d'Urville 1830) before heading for New Zealand. D'Urville considered that Cook's previous maps of New Zealand were incomplete and decided to complete them as soon as he arrived. He planned to survey the entire west coast of the South Island, pass through Cook Strait and continue surveying the entire east coast of the North Island.

By the time the Astrolabe arrived in 1826, the trade of Toi moko in the Bay of Islands had notably slowed down. D'Urville describes the purchase of one head that he donated at the Caen Museum on his return and provides valuable information about the circumstances of his exchange with one Ngā Puhi chief, Pomare II:

I have always wanted to lay my hands on one of those famous heads (moko mokai), made with the process peculiar to the people of this region, with the intention of giving it to the museum of Caen, whose collection is already so rich in many respects thanks to the wise taste of my honourable fellows. The opportunity had only arisen once, and Mr. Bertrand had then warned me. Besides, I dared not mention it first to the chiefs I met, fearing that greed would make them sacrifice ruthlessly some of their slaves to prepare his head right away and bring it to me - which had already happened more than once. Wetoï [Pomare II] came to show me secretively one of the heads, which, seeing the complicated tattoos, had probably belonged to an important figure. Except for a large tear on its left cheek caused by a wound, it was in a good condition, and I expressed to Wetoï my desire to purchase it. For a long time, he wanted a musket that I could not give him. Eventually, the sight of a colourful dress which delighted his wife who was present during our negotiation, and the sincere affection that Wetoï seemed to have for her made him decide, and the head became mine. I expressed to Wetoï the desire to know the head's history, he explained that it had belonged to a powerful Rangatira who lived by the Waï-Tamata ${ }^{6}$ and whose name was Hou; Wetoï himself had killed him a few months before. Hou was the father of a noble warrior, Inaki, of whom many Englishmen had spoken about to me with praise, and who had unfortunately perished a few

\footnotetext{
${ }^{6}$ Waitemata Harbour, Auckland, New Zealand, traditional territory of Ngāti Whātua.
} 
years earlier at the hands of the fierce Shongui [Hongi Hika]. (Dumont d'Urville 1830: 209-210)

This battle d'Urville describes was Te Ika a Ranganui where Ngā Puhi iwi faced Ngāti Whatua along with their respective allies. According to S. Percy Smith, this was one of the bloodiest battles before European settlement. This warlike event was described in detail by Smith quoting the words of Puriri from Te Uri o Hau in 1860: "where the fragments of the canoes were still lying and the ground was strewn with skull and bone fragments."(Smith 1910, 352). Puriri himself took part in the battle that "practically exterminated the tribe of Ngāti Whatua and made the people of Kaipara flee in all directions." (Smith 1910, 352) The missionary files on which Smith relied dated the battle to February 1825. According to Smith, Pomare II killed the man whose head was given to him a few months earlier. The battle followed the murder of Koriwhai of Ngā Puhi by members of Ngāti Whatua and Ngāti Maru. Led by Whareumu and Hongi Hika, Ngā Puhi went to war with about 500 warriors, almost all of whom were armed with guns. Ngāti Whatua, with representatives of all its hapū and allies from other tribes, deployed more than 1000 men but had only two guns (Smith 1910, 339$340)$.

Ngā Puhi suffered many losses from the very beginning of the confrontation, including Hongi Hika's son, Hare Hongi, and were forced to retreat. Ultimately their weapons allowed them to win against Ngāti Whatua (Smith 1910, 342). Only a few names of warriors from Ngāti Whatua who fell during this conflict are remembered: Te Toko-o-te-Rangi, who built the sculpted house just before Moremonui, Te Ahu-mua, who once lived in Hukatere, on the Wairoa, Te Tokotoko, Houtahi and Pa-te-Tonga (Smith 1910, 343-344). The author also refers to the beheading of certain enemies for commercial purposes. After the battle, in a spirit of revenge, a group of warriors from Ngāti Whatua wanted to provoke Hongi Hika. The leader of Ngā Puhi imprisoned 10 of these men after killing nearly seventy of them. Smith reports that one of the enemy leaders, named Tuhoehoe, was among the prisoners. His head and body flesh were sent to the Waikato area as a preventive act of retaliation in case of another planned attack on Ngā Puhi (Smith 1910, 350).

This conflict provides context for the encounter between d'Urville and Hongi Hika. My theory is that it is possible that Hongi Hika increased the number of Toi moko to trade with Europeans. According to d'Urville, the deceased was a rangatira from Waitematā and Ngāti Whatua. Ngāti Whatua is still the local iwi of the Waitematā Harbour (Te Ara 2008). It is 
possible to imagine the acquisition of the head after a conflict like Te Ika a Ranganui between Ngā Puhi and Ngāti Whatua. Because this conflict occurred 11 months before the arrival of d'Urville, the head of the rangatira named Hou could be associated with this battle. Nothing is clear but it would be interesting to get further information about that conflict and the relationships between Ngā Puhi and Ngāti Whatua.

D'Urville intended to donate some objects brought back, including one Toi moko, to the Museum of Caen (Dumont d'Urville, 1830, 210) following the practice of other explorers who donated collection artefacts to the museum of their birthplaces and, consequently, were regarded as city benefactors. Research in 2009 to identify the location of this Toi moko was unsuccessful. The Caen museum was unable to provide any further information because of the destruction of the archives and collections of the museum that occured during World War II (Letter from the city hall of Caen 2009). D'Urville does not mention any other exchanges involving the acquisition of Toi moko in his logbook. However, members of his crew did bring more Toi moko to France. Several other museums declare that their Toi moko were brought to France on the Astrolabe, such as the museum of Sens that obtained one from private collector Alfred Lorne (Acquisition book 1891), and noted in the donation book that this Toi moko was brought to France aboard the Astrolabe during its circumnavigation in 1827 (Press release 2012).

Another article in Le magasin Universel in 1835-1836 focuses on the trade of heads during Astrolabe presence at the Bay of Islands. The unknown author travelled aboard both the Uranie and the Astrolabe and describes his trade with a chief from Bay of Islands:

During our stay in the Bay of Islands in 1824, I pronounced randomly the words moko mokai; it is the name of these heads in the language of origin; one chief with high stature, with ferocious look and fierce features, asked me suddenly if I will give him a gun in exchange of one of them. I remembered the information I received in Port-Jackson, and I quickly answered that I did not want. The Zealander thought undoubtedly that he would get more surely an acquirer simply at sight of the goods. He came back three days later aboard the Coquille, with a freshly prepared head. The person who wanted to purchase it had to expose it frequently to the sun in order to avoid its entire deterioration. (Le magasin Universel 1835-1836, 367) 


\section{Conclusion}

In summary, the historical research in this chapter has provided context for the topics explored in this thesis, allowing us to understand the consequences of Western colonisation and settlement on Indigenous identity and cultural practices such as pakipaki māhunga. I have described the social and historical background to Toi moko and the European trade in human remains leading to their acquisition by French museums and related institutions. As this chapter shows, 10 Toi moko have been preserved in ethnographic museums (seven at MQBJC, two at Lyon and one in Marseille); seven in natural history museums (one in Rouen, four in Paris, one in Nantes and one in Lille); one in a fine arts museum (Dunkerque); one in a maritime museum (Paris); one Toi moko was held by a local museum (Sens) and finally; one Toi moko has been returned from the collection of a university (Montpellier). As I have demonstrated, in pre-European Māori society Toi moko were part of Indigenous culture, and highly regarded persons received tā moko. However, following encounters with Europeans and the introduction of a new social and economic balance, Toi moko were reframed due to the introduction of guns within Māori intertribal relations. This change in meaning, as an item of trade, demonstrates the complexity of the entire journey of Māori ancestral remains found in museums. Anne Salmond describes this process of imbalance of power between western and Pacific cultures since the early stage of contact :

Pressed, painted, written about, bottled and transported, exotic plants, animals and people were taken to the explorers' homelands to be sorted, stored and exhibited in herbaria, encyclopaedia, zoos, botanical gardens and museums... where Pacific and other 'curiosities' were brought under intellectual control. These philosophical and political encounters between Māori people and European scientists complicated affairs... Whereas European science sought to plumb the mind of God by means of maths and taxonomy, Māori philosophies described the world by means of whakapapa (genealogy), networks of interactive links between different beings of different kinds, and sought to influence it by means of ancestral power. In these early encounters the scene was set for struggles and exchanges, not just between different ways of thinking, but between Māori and European ways of being. (Salmond 1997, 32) 
In this chapter, I have shown that early explorers gathered collections and data about the New Zealand natural environment but also created a biased image of Māori culture. Those past objects, images, statements and French representations of Māori, have had lingering effects on stereotypes still active today. And those beliefs that people held in the colonial period towards Indigenous people led to conflicts, breaches and an initial inability to understand tribal perspectives at the time of negotiations among museum professionals and repatriation practitioners.

However, this study is not focused on Western complicity or guilt about this trade. On the contrary, I aim to show the journey undertaken by Toi moko since their acquisition by explorers. Arguably, Toi moko are not exclusively part of Māori history anymore, they also represent a new journey, a new attitude towards the trade, French presence in South Pacific, museum history, and last but not least the museum's contemporary role in reconciling its colonial legacy. The participation in and written testimonies about the trade by explorers and still-esteemed personalities like de Freycinet, Lesson and d'Urville reflect the successful attempt at that time to establish general appreciation towards customs like pakipaki māhunga. The trade was declared illegal in 1831 but historical documents analysed throughout the chapter reveal that there were still opportunities for French traders to obtain Toi moko after this date. The analysis of this dark historical journey of Toi moko, presented in this chapter and by other sources has, I believe, led French museum professionals today to rethink concepts such as ownership and cultural recognition. Because Toi moko were not necessarily the centre of interest for staff or the public, Toi moko heritage has been gradually forgotten. Internships and archival research have helped repatriation practitioners to gather enough data on the global context of acquisition, French and iwi relationships since the beginning of the $19^{\text {th }}$ century and French involvement in the trade.

During the period of repatriation negotiations in recent years, the French senate placed much importance on the definition of this commercial exchange as 'barbaric' and completely beyond the bounds of humanitarian principles of equality and ethics (Morin Desailly 2011). Thanks to the relationships between repatriation practitioners in each country, French authorities now have a better contextual understanding of the $19^{\text {th }}$ century and have been able to better address repatriation requests. My personal involvement in this process since 2009 is evidence of this particular lack of knowledge about these issues but highlights more specifically the lack of contact between French museums and Māori authorities up to that point. For KARP, the necessity to know more about French involvement in New Zealand's 
colonial past was crucial in order to engage in negotiations and conversations with French museum professionals. History shapes the present, and our understanding of the past can affect current professional museum practice in this difficult area of repatriation.

To date, 21 Toi moko have been returned to New Zealand though more were undoubtedly obtained by settlers, whalers and explorers. My study of the participation of French ships in the trade, their presence in the Bay of Islands and their regular stops in this bay led me to understand their interest in such strategic localisations. The presence of French vessels and religious personalities like Bishop Pompallier helps us to understand the importance placed by French royalty on augmenting its imperial authority over more territories. Also, warships were intended to protect French sailors from Indigenous communities but most importantly from English and other European competition. The European presence transformed the Bay of Island into a strategic trading post that increased exchanges with local communities and favoured future permanent European settlements in the North Island.

Having traced the acquisition of human remains in this chapter, the next chapter focuses on the museum acquisitions and the transformation of Toi moko from tūpuna into 'curios'. This now controversial expression 'curio' has been used here in order to reflect the long journey undertaken by the Toi moko since their departure from New Zealand, and their changing meanings in the context of French museum collections. 


\section{Chapter Two}

\section{From tūpuna to curios (and back again):}

\section{The museum journey of Toi moko}

\section{Introduction}

The previous chapter demonstrates that repatriation has been the starting point of a new understanding of historical French colonial interests and first contacts with te iwi Māori. Repatriation negotiations in recent times have provided the opportunity to learn more about historical changes in the meaning of Toi moko as a result of the European presence in Aotearoa. But what about the arrival of Toi moko in France? Why were naturalists interested in the acquisition of Toi moko and why did they donate them to museums? As an essential part of the complicated journey of Toi moko, their acquisition and entry into museum collections remains important as it reflects the changing position of the deceased in Western collective imagery. This chapter gives an overview of acquisitions by French museums in general and the diversity of Toi moko trading contexts and types of institutions that collected them. An analysis follows two case studies - the Toi moko in Rouen and the one held formerly at the Conservatoire of Anatomy in Montpellier. These sections lead to my examination of the complex evolution of historical attitudes towards Toi moko. The final section of the chapter is a reflexive analysis of the use of, and names attributed to, ancestral remains throughout their history.

As I pointed out in the literature review, the museum exhibition and preservation of Indigenous objects played a crucial role in conveying the imagery and ideas of Indigenous people present in Western belief systems. Every museum object considered valuable has been the subject of changing interpretations and personal appreciation over time (McCarthy 2007), a process of change that we can observe in this thesis in terms of the different views held of Toi moko. This chapter considers: How have the meanings and understanding of Toi moko in French museums changed over time up until the return of tūpuna to New Zealand? In this chapter, therefore, I analyse the various ways in which Toi moko have been named and described as documented in the archives from the time of their acquisition by European museums. This interest in collecting remains central to understanding the ways in which the 
Western public has understood Toi moko. Museums are showcases of Western views of how the world is classified and organised. In France, displays of Toi moko were directly influenced by a French understanding of Māori cultural identity. But in recent years, contact with repatriation practitioners from New Zealand museums has helped to provide another perspective on the colonial past and a re-assessment of the role of Toi moko in colonial heritage. As soon as Toi moko arrived in the collections, they attained another status, legally, culturally, and ethically. They were always placed under Western judgement. That is why the historical research presented in this chapter, in exploring the journey of Toi moko from ancestral remains to curios in museums, helps us to understand the changing European attitudes towards Māori ancestral remains before their return to their land of origin.

\subsection{The acquisition of Toi moko by museums in France}

Obtaining objects and human remains acquired in far lands during circumnavigations was considered to be a mark of wealth and nobility. The interest towards Toi moko correlates with an evolutionary science and an increasein the number of museums throughout the country. Furthermore, the range of museums interested in human remains points to the multidimensional role of Toi moko in French museums variously as curios, art pieces or elements for anatomical comparison. Not only natural history museums and ethnographic museums enriched their collections with Toi moko but also fine arts museums and universities. These different types of museums received artefacts from private collectors who became directors, as at Rouen, Nantes and Sens, and also from local cabinets of curiosities. Those cabinets furnished their collections largely with objects acquired during colonial, scientific and religious expeditions, and several explorers set out to obtain treasures from lands they visited drawn by scientific interest, profit or fame.

Among the 21 Toi moko repatriated, seven were from the MQB-JC (French Press release $2012,11)$. All seven Toi moko had arrived at the museum in 2002, shortly before it opened to the public in 2006. Prior to their arrival at the MQB-JC, they were stored in the Laboratoire d'Anthropologie du Musée de l'Homme ( Museum of Mankind). They were thus formerly part of the Oceanian collection of the musée de l'Homme in Paris, with limited associated acquisition information. A private collector who remains anonymous gave the first two Toi moko in 1885 . 'Le Printemps', a famous store, which previously exhibited the Toi moko in the gallery, had given one in 1886. Unfortunately, according MQB-JC file, the store could not give further information about the Toi moko because of a fire destroyed most of their archives 
and records in the past (MQB-JC report 2012, 1). Another one was included in 300 objects donated by Dr. Louis Capitan in 1929. Adrien Paris, a private collector gave two Toi moko in 1947. And finally, Germaine Urbain donated one in 1999 which had been obtained in unknown circumstances by one of her ancestors who had lived in New Zealand in the 19th century (MQB-JC report 2012, 1).

While museums acquired Toi moko mainly for their aesthetic attributes, "modern" scientific observation, such as phrenological experimentation, could also be accomplished with such remains from far-off, tribal communities. By the end of the 19th century, museums throughout France aimed to present a collection of human remains in order to be considered as influential institutions in Western political, cultural and diplomatic terms. The acquisition of human remains such as mummies, shrunken heads, skulls or skeletons was popular for such scientific institution and fulfilled the requirements of the emerging discipline of comparative anatomy. In 1836, Pierre Marie Dumoutier required a large collection of skulls in order to open the Phrenological Museum in Paris (Renneville 1998). Even though none of the skulls were Māori, Dumontier therefore created busts from individuals they met in Akaroa and the Bay of Islands (Lesson, 1839). Today, the main collection of busts is located in the Musée de l'Homme in Paris with the remainder in the collection of the Museum of Rouen.

Māori skulls, heads without skin or tattoo, were also analysed for 'scientific' purposes. Because Māori were presumed to be 'dying out', collectors were motivated by the belief that their remains were a finite resource. Lesson and co-author Prosper Garnot, doctor and naturalist who was aboard the Coquille, supported the scientific significance of Toi moko by comparing phrenological aspects of Māori heads in volume one of their journal dedicated to 'Zoology':

The coronal bone of a New Zealander is less rounded than the one of a European, the outer orbital angles are much thicker, and the curved line that runs through is also more prominent. [...] The nasal arch offers nothing special. The anterior part of the lower jaw is approximately the same as the European, and differs only slightly from it[...]. Finally, the bones of the skull of the New Zealanders are remarkable for their great thickness. (Lesson and Garnot 1826, 114-115) 
French people also valued the practice of donating objects, including Toi moko, to museum collections. The donation both enriched the collection of a local museum and contributed to the good reputation of the donor. Following the donation of important artefacts, in terms of quantity or quality, museums named galleries or collections after the benefactors. Museums with Toi moko acknowledged this tradition by naming collections according to the scientist, surgeon, collector or captain who donated the collection of human remains, busts or taonga. The collection Dumoutier at the Musée de l'Homme (Ackerknecht 1956) refers to a collection of busts. The collection Dubreuil, composed mostly of human heads from all over the world, is at the Conservatoire of Anatomy at Montpellier (Catalogue of Acquisition 1869). The collection Moillet in the Museum of Lille (Catalogue of Acquisition 1850) or the collection Cécille at the Museum of Rouen (Catalogue of Acquisition, 1839 and 1844) are further examples of the categorisation of human remains inside museums, which are considered as objects and are situated within collections of different artefacts. Most donors chose to give Toi moko to the museums located at their birthplaces as acts of beneficence for the cities; Drouet gave one Toi moko to Rouen, d'Urville gave one or more to the Musée de Caen, Lesson to Rochefort, Busseuil to Nantes, Moillet to Lille and Lorne to Sens.

By 16 April 1831, Governor Darling of New South Wales had signed an act banning the trade of Māori heads, describing it as "disgusting" (Robley 2003, 180). Even though the trade was now illegal, interest in Europe in the acquisition of Toi moko continued to expand. The Vénus (du Petit-Thouars 1841) is one of ships that continued to support the trade of Toi moko in different places and ports visited during its expedition. The captain Aubel Aubert du PetitThouars clearly spelt out several situations in which the ship's members could obtain Toi moko:

Since the establishment of the Whites in New Zealand, the considerable prices, that have been consistently offered in order to obtain heads of chiefs tattooed and dried out by smoke, were considered as an incentive to odious massacres, and another motivation for natives to make war, not only to eat each other, but also to obtain those objects, stem from a trade that is as scandalous as infamous. A sort of frenzy followed this commerce, or rather this horrible traffic. [...] Despite the most rigorous defences, this traffic still 
carries on, even if under more restrained_limits. During the transit of Venus at Kororareka (Bay of Islands), we saw a ship coming ashore, a small schooner that came from Tauranga, located in the western part of the bay of Abundance; this ship was sailing under the New Zealand flag, and was commanded and partly armed by English. The captain invited me to buy a bag full of those dried heads, and he was assuring me of their good price, because, he said regretfully, that several of them have been damaged by rats during the crossing.

Being at Rio de Janeiro in January 1825 [he was the captain of the Inconstant and stayed in Brazil from 1823 to 1826], we had to pay six thousand francs for two heads, similar to New Zealanders, which were remarkably beautiful, by the regularity of the tattoo and their high quality of preservation.” (Dupetit Thouars 1841, 39-40)

Du Petit-Thouars also acquired a fully carved funeral monument dedicated to Pōmare, a Ngā Puhi chief who was born in 1760 and died in 1826. According to his journal, Thouars purchased this monument along the Kawakawa river with the aim of donating it to the MNHN. He wanted to place this carving in the botanic garden where he thought, "it will make a great effect" (du Petit-Thouars 1841, 109). Unfortunately, this piece was too large to be loaded on the ship and the captain decided to fasten it to the mast (porte-haubans d'artimon). This artefact was severely damaged by the ocean during the return journey, and the French could not rebuild the carvings exactly as they were. Nowadays, there are still numerous questions regarding the story of this carving and its ultimate fate. Did French curators at that time register it in the collection of the museum? Did they destroy it? Further research needs to be undertaken in order to find out where it is and more about it.

Several French exploratory and whaling expeditions sailed into the South Pacific after 1831. Their great interest in obtaining Māori treasures was unaffected bythe ban signed by Governor Darling in New South Wales. Cyrille Pierre Théodore Laplace (Laplace 1853), Jean Baptiste Thomas Medée Cecille (Faivre 1954: 417) and Abel Aubert du Petit-Thouars (du PetitThouars 1841) are just a few examples of captains who obtained Māori taonga while in New 
Zealand. Even if we do not have any records of their acquisitions of Toi moko, the trade of human remains definitely continued behind the scenes.

\subsection{The research on the Toi moko returned from Rouen to Te Papa}

In October 2011, the manager of KARP Te Herekiekie Herewini decided that further research needed to be undertaken on the donor of the Toi moko at Rouen. Because the Museum of Rouen was the first French museum to launch the process of repatriation of Toi moko, KARP insisted on working with this institution on the early stages of the research. The aim was to work both in France and in New Zealand researching the journey of each of the human remains.

\subsubsection{The genesis of repatriation practice}

The Museum of Rouen was closed to the public between 1996 and 2007 due to concerns about its structural safety. The director Sebastien Minchin appointed in 2006 started an inventory of the collections (Minchin 2019, 5'min). Roger Boulay used this opportunity to visit Rouen for the second time in order to complete the inventory of the Kanak collection. He was also responsible for completing a national report on the Pacific collection. While he was in the storage, he found a wooden box containing a Toi moko (Boulay 2019, 3 'min). Together, Boulay and Minchin discussed the possibility of returning the Toi moko to New Zealand. Even though they were not yet aware of the existence of KARP, Boulay's experience with Kanak representatives, such as Jean Marie Tjibaou, led him to perceive objects not only as parts of a collection but as full elements of each community's cultural identity (Boulay 2019, 4'min). Minchin contacted the New Zealand Embassy in Paris to seek information about potential repatriation processes (Minchin 2019, 9'min).

At this stage, the first contact was, interestingly, initiated by a French museum and not New Zealand authorities. The Rouen City Council organised a handover ceremony in October 2007, inviting a Māori delegation to the city hall. Tumu Te Heuheu chief of Ngāti Tūwharetoa and Māori representative at UNESCO led this delegation. This first attempt was organised in order to return the only Toi moko held by the city's institution since 1875 . By inviting communities of origin to play a role in museum activities, the Museum of Rouen was exploring new approaches to museum practice (Morin Desailly 2019, 6'min) and the repatriation operation was seen to encompass the new museum policy of being a "sustainable and responsible" museum (Minchin 2019, 6'min; Morin Desailly 2019, 8'min; Van Praët 2019 , 15'min). This decision to return human remains challenged the traditional conservative 
museum approach and changed the objective of museum collections away from the traditional model and towards what Thomas describes as a "maker of relationships" (Thomas 2016, 19).

On the day of the repatriation, the French Ministry of Culture opposed the return because the Toi moko was held in a museum granted the status of 'Museum of France' (Peltier and Mélandri 2012, 29). According to the Heritage Code (Code du Patrimoine, CDP), the collection inside a 'Museum of France' is inalienable and imprescriptible, a rule established by article L.451-1 (version in force at October 2007). The decision taken by the Ministry of Culture showed the disparate view that, in France, human remains preserved in museums are also research material to increase knowledge about humankind's evolution (Van Praët, 9'min). Human remains are regarded as artefacts of a museum collection on the same legal level as other collection articles. Consequently, the conditions of preservation seemed to be same as for any other ethnographical items (Van Praët 2019, 7'min). This debate on the legal status of human remains and their return demonstrates that human elements cannot be defined by one simple categorisation (Cadot 2006; Cornu 2009; Patin 2014).

The unsuccessful repatriation in 2007 in Rouen revealed the ethical and legal contradictions concerning human remains in French museum collections but also the ambiguous role of ethnographic collections in modern museum work. It took four years of negotiation between senators, anthropologists, curators, directors of museums and scientists to decide the debate on the repatriation of Toi moko. During those years, the translation and cross-cultural communication carried out during my internship in 2009 helped the senator Catherine Morin Desailly get enough understanding of the situation to propose a law that was voted on unanimously on July 19, 2010 (Senate Website, accessed 14 November 2018). The vote was also the first led by the new minister of culture, Francois Mitterrand (Morin Desailly, 8'min). Less than a year later, on 9 May 2011, a second ceremony was held at Rouen's city hall and the New Zealand delegation finally had the chance to recover the head of a Māori ancestor. Te Herekiekie Herewini, Michelle Hippolite (Kaihautū), Rosemary Banks (New Zealand ambassador), Victoria Hallum (Deputy Head of mission at the NZ Embassy in Paris) and two kaumātua Te Kanawa Pitiroi (koroua) and Kataraina Pitiroi (kuia) comprised the New Zealand delegation.

However, attempts to continue this debate after Rouen's experience were hampered by a lack of knowledge on how the Toi moko had been obtained and the historical context in which the acquisition occurred. It was also hindered by the gaps between French museum practice and 
Māori beliefs and protocols with regard to ancestral remains and their whakapapa (genealogy).

\subsubsection{Research on Mr Drouet}

The relationships created by repatriation do not have to end with the actual return of the ancestors. Collaboration is able to be sustained through developing research within each museum on the background context of the acquisition and the donors, as revealed in my research in this chapter and Chapter One. For contemporary museum professionals to understand and appreciate the issues involved, it is very important to trace the history of the traded head and possibly to find the territory of origin of the ancestor.

The case of the donor of the Toi moko at the Museum of Rouen is significant at an international collaboration level, both because it represented the first research undertaken on Toi moko preserved in French collections, and because of the lack of information available to both sides of the repatriation process, for the French as much as the New Zealanders.

The Rouen museum's acquisition book provided the only details of original possession:

Given by Mr Drouet

(131 Morny street, Paris)

One head of a tattooed savage

Yellow race of New Zealand.

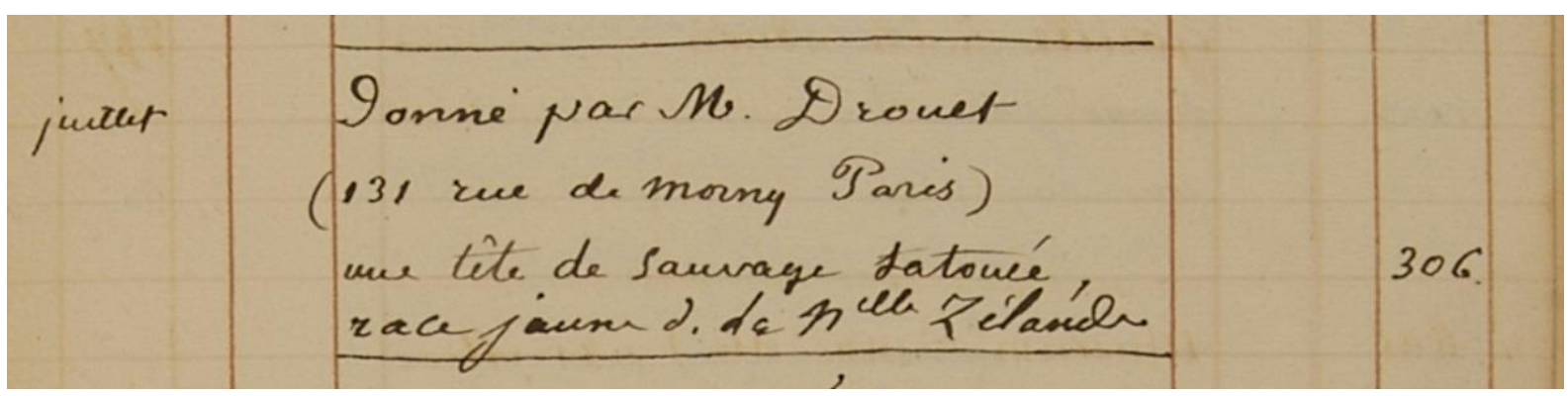

Figure 1 Acquisition book of the Muséum d'Histoire Naturelle of Rouen, photo by Simon Jean.

Drouet donated the Toi moko to Rouen in 1875 . Created in 1828 in a former abbey which had been transformed into a medical school in the $18^{\text {th }}$ century, the museum rapidly became a well-known scientific institution for biology, zoology, medical education and pharmacy (Rouen Museum website, accessed 12 May 2016). This institution had a strong interest in 
obtaining foreign collections and, in particular, specimens such as skulls that were used in the study of phrenology. The institution opened to the public in 1834 with its first director, Félix Archimède Pouchet who had a strong interest in educating a larger public around these scientific areas. In 1875, surgeon and scientist Georges Pennetier was the director and curator of the museum (Rouen Museum website, accessed 12 May 2016). Drouet would have had to meet him when he visited the museum in order to donate the Toi moko. It is possible that Drouet had an interest in supporting research and science at the time, and wished to donate the Toi moko to an institution that was showing a high interest in this type of study. Since he was living in Paris, why did he choose to donate the Toi moko to the Museum of Rouen and not the national museum of Paris? Moreover, Drouet only donated the Toi moko and no other artefacts.

The Museum of Rouen's acquisition book provides essentially the name of the donor and his address. With this information, I undertook to investigate different French archives, and, in particular to research any information that could provide more details on Drouet and his association with the Toi moko. The first step was to precisely locate the "rue de Morny". This could indirectly give us information on the man's standard of living. Since 1861, French authorities had divided Paris into 20 districts or arrondissements. Each district had its own city hall, mayor and administration office with staff. Today most districts still retain their own central archives, so a search was carried out to establish the area where Drouet lived in 
Paris. This information would lead to the next stage of the research, contacting the relevant city hall to request access to the archives.

According to the Parisian registration of streets $^{7}$, accessed 8 December 2011, rue de Morny no longer exists as the name has been changed. After searching any trace of rue de Morny online, an electronic copy of Ancient houses of Paris-History of Paris street by street, house by

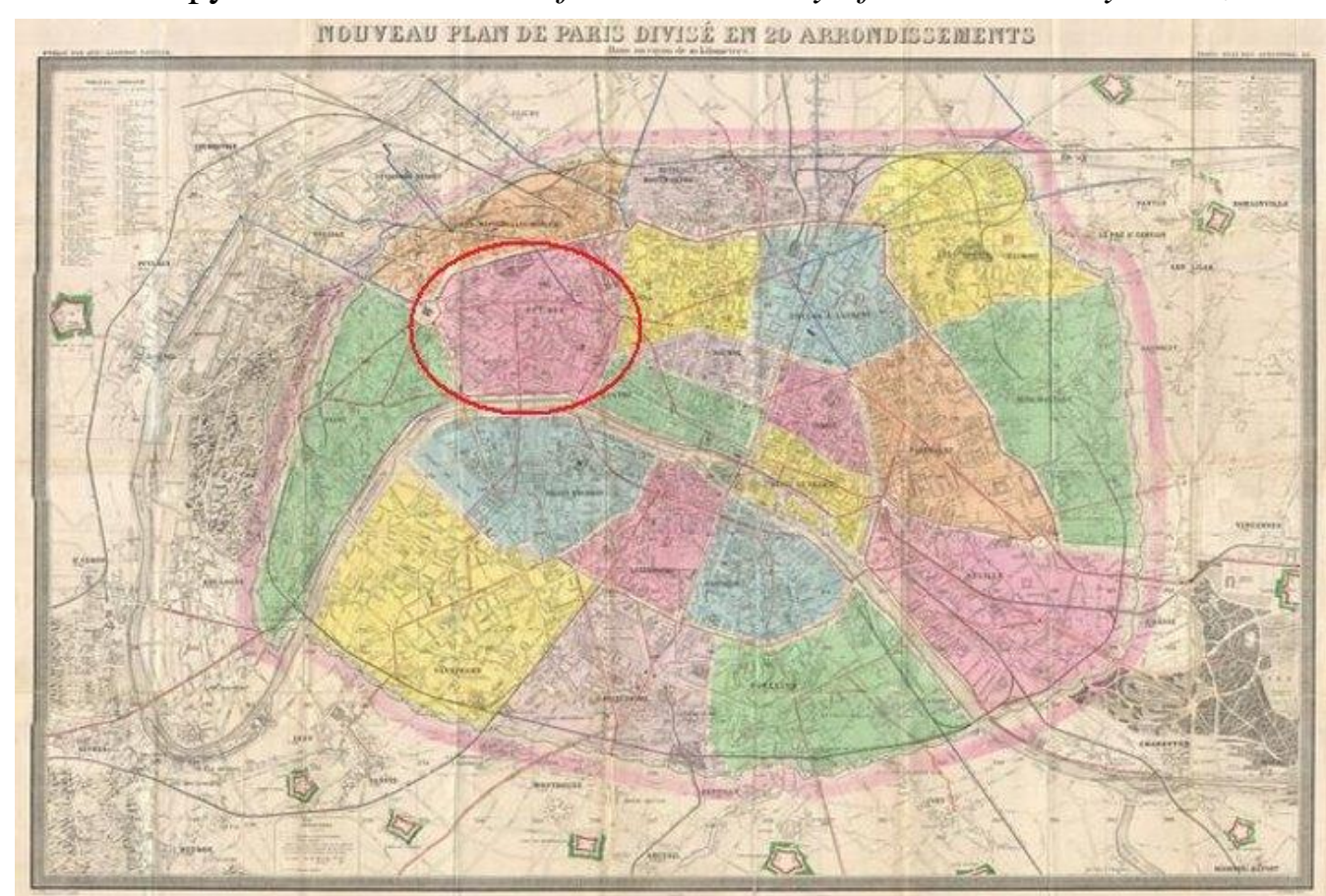

Map 1: "New Plan of Paris divided into 20 arrondissements" and the eight arrondissement, 1878. (Histoire de Paris par ses Plans, laboiteverte.fr, accessed 12 november 2018).

house by Charles Lefeuve edited between 1818 and 1882 allowed more information ${ }^{8}$. This book showed that "rue de Morny" was initially named "rue d'Angoulême-Saint-Honoré" and the footnote of this same page specified that rue de Morny crossed the Champs-Elysées.

With this information, I could expand my research to the "rue de Morny" which was separated into two parts in 1879 named "rue Pierre Charron" and "rue de la Boétie". On the registration of streets of Paris website, I discovered that "rue de Charron" and "rue de la Boétie" were located in the eighth arrondissement. To confirm the location of rue de Morny, a map of Paris dated from 1878 with the amended city plan was found on the web (www.laboitverte.fr/historique-des-plans-de-paris). On a map found online dated 1861 and

\footnotetext{
${ }^{7}$ http://www.v2asp.paris.fr/commun/v2asp/v2/nomenclature_voies/Voieactu/index.nom.htm

${ }^{8}$ Tome 1 by Lefeuve, Charles (1818-1882). This extract is available on the National Library of France website: http://gallica.bnf.fr/ark:/12148/bpt6k202791k/f55.tableDesMatieres (accessed December 9, 2011)
} 
named "New Plan of Paris divided into 20 arrondissements", we can clearly see all the different arrondissements and their locations inside the city. My interest was focused on the north west of the city and the eighth arrondissement. This arrondissement was known to be a wealthy quarter with many traders, businesspersons, and nouveau riche residing at this time. A part of the most famous street of the French capital "avenue des Champs Elysées" cuts through this arrondissement.

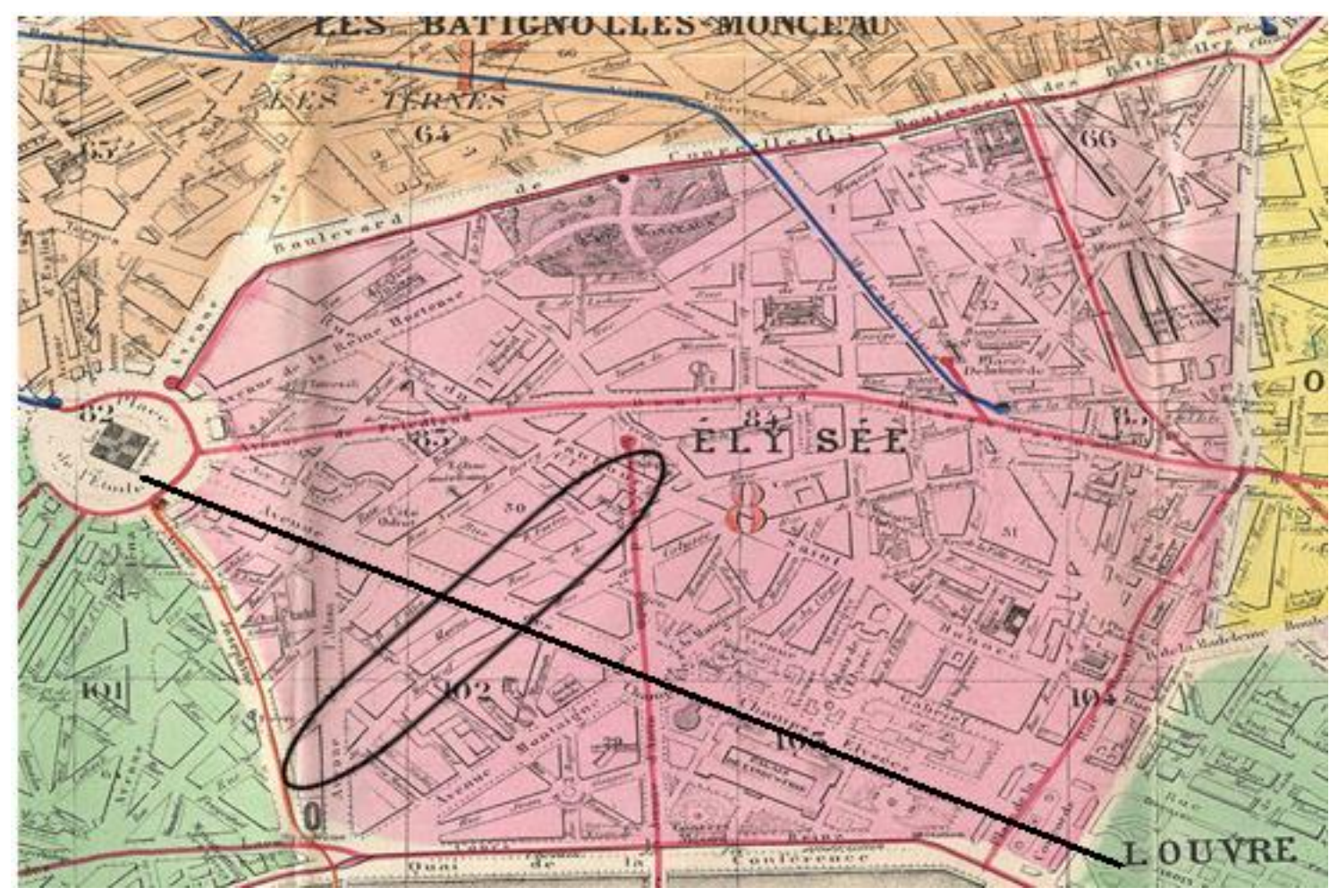

Map 2: Map of the eighth arrondissement and the locality of the rue de Mornie (Histoire de Paris par ses Plans, laboiteverte.fr, accessed 12 november 2018).

Having obtained this new piece of information about the location of the street, my research became focused on the person of "Mr Drouet" by concentrating on the archives of the eighth arrondissement. Contact was made with the eighth arrondissement's city hall, and in response they indicated that their archives were now held centrally at the Paris City Archive. After several months of research, I managed to form a hypothesis concerning the possession of the human remains by this man.

In January 2012, research was carried out at the Parisian archives . An election list (Political Election List, D.1M2 180) dated 18 June 1871 gave personal information concerning Drouet. This election list included all voters in each district of the eighth arrondissement (in 1871, women were not allowed to vote in France, this did not change until 1944). In the section 
dedicated to the Faubourg du Roule, the name of Drouet appeared and corroborated with the postal address written in the acquisition book of the museum. This document provided general information about the donor of the Toi moko, his first name, his place of birth, and finally his job at that time. Louis Hegesippe (or Eugesippe) Drouet was born on 8 September 1817 in Martainville du Cormier (a village near the city of Evreux in Normandy). In this parliamentary election list, he introduced himself as a landowner.

It was now possible to conclude that Drouet was 58 years old when he donated the Toi moko to the Museum of Rouen in 1875. By having his full name and place of birth, it was easier to find his death certificate on two of the digitised documents in the archives (Death Certificate 1873-1882, Drouet D1M9 812; Death Certificate 12/02/1882 V4E 3470). Both documents declared that Louis Hegesippe was single. He died at 11pm on 11 February 1882 at his home, "82 rue de la Béotie". Previously 131 rue de Morny, the street change had been applied only three years earlier. This same document described Drouet as a businessman. The witnesses are Léon Louis Loison, his stepfather and Léon Francillon, his friend.

After a few days spent in the archives of the city of Paris, an additional, relevant document was found. The death certificate dated 20 November 1861 (Death Certificate 20/11/1861 V4E 880) was of Jean Pierre Elme Leduc, also known as Saint Elme Leduc, who died at home, 99 rue de Chaillot. On the same document, the name Louis Hegesippe Drouet appears as one of the witnesses along with his signature. In this document, Drouet is described as the employee of Jean Pierre Elme Leduc. Notably, Drouet's 1861 postal address on the document was different from the one already known - 60 rue des Acacias, in the 18th arrondissement.

Leduc was a wealthy entrepreneur who owned land both in France and in overseas colonies and territories. According to his book Histoire civile et militaire de l'ile de France, Jean Pierre Elme Leduc owned land in the Agaléga Islands (or the Galéga Islands), an archipelago located in the north of the Republic of Mauritius (Leduc 1884). In 1884, Leduc was not only a writer but also a member of the India Company. He also owned land on different islands throughout the Indian Ocean. He had a brother, Auguste Leduc who wrote his memoirs during his stay on Agelaga/Galéga Island(Pourcelet 1994).

Auguste Leduc befriended the second lieutenant of the Artémise, Léon Martin Furmichon (Pourcelet 1994, 36). This assumption was confirmed by the second volume of the journal of exploration written by the Capitain, Pierre Cyrille Théodore Laplace in 1842 . When the Artémise anchored in Galéga Island, their contact in the islands was Auguste Leduc (Laplace 
1842, 120). There is then a possibility that Furmichon may have acquired the Toi moko during his journeys aboard the Artémise, and subsequently gave it to the Leduc family. They in turn may have passed this onto Drouet, who then gave it to the Museum of Rouen in 1875. No reference to such a transaction between Jean Pierre Elme Leduc and Louis Hegésippe Drouet was found in Leduc's will, declared on 17 December 1861. On the other hand, Auguste Leduc could have easily acquired the Toi moko in Port Louis, capital city of Mauritius. This island in the middle of the Indian ocean was also a known trading post for Toi moko (Aranui 2018, 9). Agalega is near Port Louis and is today part of the Republic of Mauritius.

Even though I do not possess any proof to confirm such theory, I can affirm that the information concerning Drouet helped to understand the context in which the donation could have occurred in France. The donor of the Toi moko in Rouen moved between 1861 and 1871 and left the 18th arrondissement to go to the eighth arrondissement where he lived until his death in 1882. By pure chance or choice, he moved to the same area as his former employer. No more information has been found on the archives in either Rouen or Paris concerning Drouet. One of the outcomes of this research is demonstrating how difficult it is to recreate the entire journey of a Toi moko when so little information can be found on the donor. Further research needs to be undertaken on this topic. Nevertheless, this section of the chapter has demonstrated how historical research has thus made a significant contribution to the contemporary understanding of the complex historical acquisition of Toi moko and has thereby helped advance the repatriation negotiations and, I will argue below, transform museum practice.

\subsection{The head at the Conservatoire of Anatomy at Montpellier}

The Conservatoire of Anatomy, affiliated to the medical school of Montpellier, returned one Toi moko on the occasion of the repatriation ceremony organised at the quai Branly. However, questions remained regarding the rest of the collection and the possibility that another Toi moko remains in the collection of the conservatoire (also called Museum of Anatomie). The following research report describes the first steps taken in order to find the exact origins of one specific head.

The city of Montpellier is renowned for establishing the oldest medical school in the Western world. Created in 1180, Montpellier rapidly affiliated with its academic history. With the emergence of medical education, the medical school, created in 1795, (Montpellier 
University, n.d) obtained a heterogeneous anthropological collection showing the variety of the nature of the human body. Thanks to the donations of many collectors and doctors, this university department created a conservation site to preserve its collections. The Conservatoire of Anatomy also presented comparative studies and proceeded to research racial classification which was considered relevant at this time. Located across the street of the main entrance of the "Jardin des Plantes", the School of Health and the conservatoire have contributed to a scientific centre of international stature.

\subsubsection{The dried head of an inhabitant of Oceania}

The first meeting with the team of the conservatoire was held on Tuesday, 17 March 2015 at $2 \mathrm{pm}$ at the main entrance of the Botanical Institute with Noémie Miralles Aumasson who worked at the scientific centre of the University of Montpellier. The context of acquisition and donors were the first issue of this research. While initially discussing the important donation by Auguste Bérard, Aumasson told me that, according to the records of the museum, the two Māori heads preserved in their collection were not given by Auguste Bérard but by Joseph Marie Dubreuil, naval surgeon and teacher. The professional career of this man led him to work in cities where the commerce of Toi moko was particularly active in France. He was the first professor of anatomy at Rochefort then professor of surgery and physiology at the School of Toulon and finally professor of anatomy at the Faculty of Medicine of Montpellier (Dulieu 1961, 33). He became chair of anatomy at its foundation in Montpellier in 1824. His scientific interest was not only focused on surgery but also on comparative anatomy. Under the tutelage of Marcel de Serres, professor of geology and mineralogy, Dubreuil worked with Professor Jeanjean, curator, zoologist and comparative anatomy preparer. Through his relationships and professional career, it is possible that Dubreuil developed an interest in the human remains of non-European origins, and it is highly likely that he wanted to advance the cause of the Conservatoire by enriching its collection with new anatomical parts and in particular pathological anatomy. Perhaps it was under his leadership that the new museum, built in 1850, under the deanship of Jacques Etienne Bérard, ${ }^{9}$ included two annexes devoted entirely to comparative anatomy (Dulieu 1961, 42).

Two years after the death of Dubreuil, his family decided to leave some of his collections to the Conservatoire of Anatomy. In 1854, a mention of heads first appeared in the acquisition records under the label "no 187-190, four heads prepared through desiccation (sic) including 2

\footnotetext{
9 Auguste's brother.
} 
Arab, 1 Indian of the South Sea, 1 Malay”. In 1917, the Conservatoire made changes in its classification and inventory system. All the collections were sorted according to the numbers of the wall cabinet (armoire) in which artefacts were stored. Moreover, a new designation appeared on the labels giving more clues to the origins of the deceased: "No. 66: inhabitant of Oceania head with tattoos, prepared by way of desiccation." (Catalogue général du Musée $\mathrm{d}^{\prime}$ Anatomie, $\mathrm{n}^{\circ} 1$, Armoires 1 à 14 et armoire $\mathrm{n}^{\circ} 16$ 1869). In the same year 1869, the Toi moko was exhibited in a gallery called "Squelettologie (heads of different races)" (Catalogue general du Musée d'Anatomie).

Aumasson and Caroline Girard, head of collections of the Conservatoire of Anatomy, showed a key interest in the provenance research undertaken about the head. Together we have been able to access the window where the head is still located. The records of the Museum of Anatomy noted that the head remained in the museum collections of Pacific origin. Doubt persists regarding its affiliation with a Māori community. Only a label located on the forehead saying "no.65 Inhabitant of Oceania" references the origin of the deceased.

There is no evidence of the identity or the origin of the deceased but close observation still raises questions. The head has traces of vegetable fibres inside the skull. If those fibres turn out to be phormium tenax, this will prove the head's affiliation with New Zealand. These strips are located behind the eyeballs and nostrils. The eyes have been removed from the orbits and the cavities are filled with wooden eyeballs. In some cases, Toi moko preserved in European collections could undergo transformations like this after the initial funeral protocols (Musée du quai Branly 2011). Some Toi moko initially located in France have been altered, including a Toi moko formerly preserved at MQB-JC (inventory number 71.1947.57.2). The eyes are filled with red wax according to the report made before the repatriation (Musée du quai Branly 2011, 16).

There is no trace of facial tattoo or grooves on the face of this Toi moko at Montpellier. Despite missing information concerning the former interest to acquire such human remain, the Conservatoire has put some importance on learning more about the pakipaki māhunga process and Māori funeral protocols. More research will be required, however, before any repatriation 
procedures are planned in order to sustain the collaboration between the French university and KARP.

\subsubsection{Second visit to Montpellier}

A second visit was organised to develop further theories on the origin of the number 65 preserved head displayed in window two of the Conservatoire of Anatomy in Montpellier. The main goal of this second visit was to gather more information on the donor of the large anatomical collection that included the two heads recognised as originating from Oceania according to labels and archives. The purpose of this research contract was to investigate archival sources and documents associated with the Toi moko housed at Montpellier University in order to obtain historical evidence that could confirm a direct link between the head and New Zealand.

This objective was potentially achievable by two steps:

(1) Historical and archival research in France that confirmed provenance to New Zealand; and

(2) Another thorough physical analysis of the Toi moko to identify anything associated with it, on it or attached to it that associates it with New Zealand.

As was discussed in the first report, the dried head in question was labeled "\# 65", "Dubreuil collection", "inhabitants of Oceania" on the front of its head. This second visit took place from Monday 11 July to Friday 15 July 2016. Aumasson, who was responsible for the museum collection, was once again the first person contacted. Via email, she advised me to contact the head of the archives of the University of Montpellier, Sophie Dikoff. Appointments were made for Monday 11 July and Wednesday 13 July in the main entrance hall of the medical school where the name of Joseph Marie Dubreuil appears on the wall as a "benefactor" of the University in 1832.

Following Dikoff's advice, documents were found including the deliberations of the Medical Faculty Department Council (Délibérations du Conseil de 1'UFR). The register 1MED47 the "Order of Appointment" dated from 14 March 1832 notes Joseph Marie Dubreuil as the first dean of the new chair of anatomy, commencing 29 March 1832. Volume IV of Dulieu's 1988 book "Medicine in Montpellier: From the first to the third republic" describes Dubreuil's lack 
of interest in the position of Dean, which is why he only occupied this position for four years. The decree of 31 December 1836 testifies to his replacement (Dulieu 1988, 72).

Another document from the "Ancients Fund" collections at the Library of the Medical School refers to the donation of the Dubreuil family to the Conservatoire of Anatomy in 1854:

In 1854, the family of Ernest Dubreuil finally put a collection of shells and another 42 pieces of human anatomy or compared with an adult skeleton kind siren but also a whale penis and especially a remarkable collection of 104 heads (96 natural and 8 molded) from the different peoples of the earth, which will unite, in 1876, another donation FAGES not comprising not less than 50 , this time all casts. This set always knows the favors specialists in anthropology. (Dulieu 1988, 320)

The number of heads donated by the Dubreuil family is more significant than initially found in the acquisition register which listed only 79 heads. Dulieu refers to a collection of 96 human heads among which Māori heads could have been included. Unfortunately, in view of the paradoxes found and the meagre information about Māori heads contained in the archives, it is still difficult to trace the path of these heads. In the register 1MED48 on 19 November 1852 , the board of the faculty refers to Dubreuil who had recently disappeared. However, no further reference has been found on his collection.

During the first meeting at Montpellier, Aumasson said that the former conservatoire staff created a file about the repatriation. François Michaud, a researcher from the University of Montpellier who has followed the repatriation process, had a copy of the file in which information on the Toi moko repatriated and other heads still preserved is available. According to the research conducted at the time, the team at Montpellier appealed to Michel Van Praët, curator at the Museum of Mankind in Paris, in order to have him make an expert examination of these two heads. According to these observations dated 29 November 2011, the first one was "authentic" with its tattoos and its various ornamentations that prove the Māori identity of the deceased. Regarding the second, he said it was "false" because hair had been grafted on to the head. The head had no ornaments or tattoos. This evidence revealed more clues as to its origin. Finally, the teeth appeared to be more fragile than those of the heads prepared through pakipaki māhunga. For all these reasons, Van Praet felt it was still too early in the repatriation operation to include such a dubious example. 
He alluded to information written by Dubreuil about the heads in his own collection. This anatomical, phrenological study is entitled "Anatomical studies of heads that belonged to individuals of various races". No version of this study was found in the archives of the faculty. In 1837, reference to this study was made in the "Annals of Natural Sciences and weekly records of the meetings of the Academy of Sciences, Volume 4". Here, members of the Academy of Sciences analysed the academic text. A paragraph concerned examination made by Dubreuil on two heads from New Zealand reads as follows:

Mr. Dubreuil finishes his memory by the description of two heads of New Zealand, one man and one woman, both with their skin, their hair long and straight, and so well preserved that author does not hesitate to apply their famous phrase of Fontenelle, on the admirable preparations by Ruysch. Mummies of Mr. Ruysch, says Fontenelle, prolonged life in some way, rather than those of ancient Egypt which prolonged death. In the human head of New Zealand, the skull is elongated rather than spherical; the front, convex, slightly tilted back, without fleeing. The face has a fairly regular oval; the jaws are rounded. (1)

Footnote: (1) Our head of New Zealander is remarkable for the extent of the temporal fossa, and the projection forward of the chin process (note rapporteur) (Académie des Sciences 1837, 575)

The report's conclusions were adopted by the Council of the Academy but no further references appear in the records of the Council's deliberations. Research conducted in 2011 highlighted the conservatoire archive material inventories 4 and $4 \mathrm{a}$, which are now kept at the medical library. These inventories, dated from 1869, describe the head No. 66 as "head of the population of Oceania, with tattoos, prepared by way of exsiccation [sic].” This description also appears in the "Catalogue général du Musée d'Anatomie, $n^{\circ} 1$, Armoires 1 à 14 et armoire $\mathrm{n}^{\circ} 16^{\prime \prime}$ and on the copy of the new inventory numbers made in 1917 . The number 65 is also described as "head of the population of Oceania, prepared by way of exsiccation". Going by the same description of the two heads, including the Toi moko $\left(n^{\circ} 66\right)$ returned in 2012 , the second one could be the women's head that Dubreuil refers to in his thesis of 1837.

Register 3 of the general catalogue indicates that Dubreuil's descendants on 3 September 1854 donated a group of 79 heads, but the same register also indicates that Dubreuil regularly donated anatomical specimens throughout his career. These results correlate with the results 
from the first visit in 2015. While the document in which reference of the two heads of New Zealanders were found dates back to 1837 , doubt persists concerning the date of donation. We found records from 1854 but it is possible that Dubreuil donated Toi Moko throughout his lifetime.

However, the existence of the head of a woman, described as the second head studied in his thesis, is still likely to be among the museum collections. There is yet no evidence that the woman's head is the one analysed during the first visit. It is possible, however, to imagine the simultaneous donation of the two Māori heads and to assume that the head $n^{\circ} 65$ could in all likelihood be the woman. Considering the successive numbering of the two heads, No. 65 and 66, and the similarity of the descriptions, except for mention of the tattoo in the records, it could be possible that they share the same origin. During the research conducted in 2011, Van Praët concluded that the head was 'false'. Seemingly, lacking a tattoo and possessing fragile teeth and hair implements are elements that, in his opinion, do not confirm Māori origins.

Before joining the university's Academy of Medicine, Dubreuil was a naval surgeon whose journey in 1816-1817 aboard the Eurydice to the French colonies could have allowed him to obtain his important collection of heads from various foreign jurisdictions. His friendship with Auguste Bérard could also be a link in the acquisition of a part at least of this collection. We also know that his interest in phrenology throughout his career probably led to him obtaining this type of anatomical collection. In his scientific paper on heads referred to above, Dubreuil refers to two items that would have been acquired before the 1837 publication of the analysis by the members of the Academy. After his short stint as Dean from 1832 to 1836, he preferred to concentrate his time on his anatomical research,teaching and lectures. The acquisition register alludes to "2 Arabs, 1 Indian of South Sea and 1 Malay". The preservation technique used suggests that this head is not a head of an Asian person but more likely to be from Oceania. Although categorised by its label as "Resident of Oceania" there is no evidence of its origin and the team of the Conservatoire of Anatomy requested DNA samples in September 2016. This head analysed in these two visits is still in the Conservatoire. Because of the acquisition number, and the description in the acquisition book similar to that of the Toi moko repatriated in 2012, there is still a strong assumption that it is of Māori origin.

\subsection{The evolution of names attributed to Māori ancestral remains}

Aside from the complexity of the detailed archival research required to identity Māori human remains in French collections, repatriation research also raises interesting questions about 
words and terms that are used to describe, define or interpret these remains according to the context in which they are located. The analysis of different names shows the values placed on ancestors by descendent communities, buyers, scientists and museum professionals. This nomenclature also helps us understand the circular journeys of Māori heads from New Zealand to French collections and back to New Zealand. As soon as they became part of French collections, French scientists changed the initial definitions used for these objects. The labels "Head of savages" at the MNHN in Paris, "Cannibals" at Sens, "head of chiefs from New Zealand" at Montpellier, "One head of a tattooed savage from Yellow race of New Zealand" in the Museum of Rouen, all express an interest in classifying the heads according to western codes that digressed from the Indigenous understanding of them as tuppuna.

Europeans moved Māori heads, and all other taonga, away from their original purposes by seeing them as curios and art pieces. Europeans created an imagery of Māori culture which conveyed violence, murder (with Marion du Fresne) and cannibalism without paying attention to Indigenous sentiments of respect, reverence, and protocols concerning the heads of loved ones and highly respected enemies. Europeans stereotyped all Toi moko according to the protocols afforded to heads of enemies defiled and ridiculed by displaying them on the barricades of the pā. Furthermore, after Europeans knew about the action of tattooing and preparing the heads of captives, they generalised that this funeral practice was only performed on slaves. This sustained the Western triangular imagery of Indigenous-savage-cannibal towards inhabitants of Pacific islands (Boulay 2000, 18).

The use of names can also reflect a French way of understanding their journey and their diverse appreciation. Are we talking about human remains? Are they heads of savages? Are they heads of chiefs, warriors or slaves? What is the appropriate term to use in te reo? Toi moko or Mokamokai? Museum professionals in France and New Zealand have asked these questions throughout the negotiations and throughout this research. "They have kept them less religiously since the Europeans started buying them," comments one French writer, "and it often happens that slaves are sacrificed with the intention of selling their heads" (Lesson 1839, 378). The image of the savage imposed by the French on indigenous communities created an imbalance between the French point of view of Māori cultural identity and that of Indigenous people themselves. This came out clearly in my interviews:

During a conversation not long ago, I realized that some museum members, with a certain ideology of the museum, did not allocate this concept of 
ancient heritage to the native populations. I mean that they did not imagine that these objects dating back more than 150 years should not also be considered as part of the past for the original populations. "It's been a long time since we've hunted with spears, we no longer use our baskets" and yet the image still persists. And yes, it is quite symptomatic of the political drifts which are based on an absolutely total ignorance of the conditions in which people live their tangible and intangible heritage". (Boulay 2019, 37 'min)

This type of judgement played an important part in the general conviction that colonisation and attempts to annihilate Māori customs were beneficial for French colonial ambitions towards so-called 'Civilisation'. By using this approach, Europeans created their own definition of the term 'slavery' in Māori society without including the Indigenous understanding. Consequently, KARP helped to clarify the meaning of tikanga in order to acknowledge Māori tribal definitions within international global understanding. The observations of Māori experts during negotiations to return ancestors can help uninformed people to understand essential, contemporary Indigenous concepts such as tapu, mana and whakapapa. Although persons involved in the trade of human remains placed less spiritual value on slaves than chiefs, all human remains were and still are tapu. All Māori human remains are ancestors without any differences and should all be repatriated (Cairns, 9'min).

Today, some French museum professionals interpret the importance of human remains according to their social status. This has created problems in terms of ethical tribal recognition and constant research to find someone to 'blame'. Furthermore, museum professionals who are against repatriation may use the fact that Māori played a role in the traffic too, and initially agreed to give human remains away, to discount the possibility of returning remains. At the time of the trade, some Māori groups were in conflict, however, European imagery portrayed Māori pre-European settlement as living at a time of interminable conflict. As referred to in chapter one, the presence of settlers and explorers sustained this tension by increasing demands for human remains and other features in exchange for weapons. Furthermore, considering Māori as one unique Indigenous community ignores the diversity of tribes throughout New Zealand. Sharing common whakapapa or genealogy is regarded by Māori to be more important than any past social position of their ancestors. In an interview, Puawai Cairns observed that: 
Repatriation is about igniting Indigenous communities who are restoring themselves, in spite of and despite of what the colonised power wants to do. Our process is about "let's rebuild, let's re-indigenise, let's reinvigorate". And if a taonga can do that, help with that, it is where repatriation discussion can start but it is about recognition first. We want, maybe, to have access to it, we want to understand how you interpreted it, we want to know, and we want to help you. How are you talking about us? So that's a much broader, much more complicated discussion. (Cairns 2019, 58'min)

Although Māori society changed radically following the arrival of Europeans, the tribal organisation of the community remains in place and is indicative of the sustainability of Indigenous culture in New Zealand. Repatriation is seen as a process of recognition but it seems that it can also be viewed as a method of affirming the richness of indigenous cultural heritage, according to current Indigenous criteria based on present Māori identity.

This discussion of categorisation and nomenclature is also a sensitive issue in te reo Māori. Throughout New Zealand, at different times and with differences of dialect, several names have been used to describe the heads of deceased such as mokaikai (Biggs 2012, Williams 2005), mākiri (Biggs 2012) or upoko tuhi (Te Awekotuku 2007). There is no evidence concerning the original name, but those three expressions appeared to have been used (Biggs 2012, Te Awekotuku 2007, Aranui 2018). Two expressions appear to be the most common today when talking about Māori human remains: mokomokai (or mokamokai) and Toi moko. They were extensively employed during the negotiations between France and New Zealand, and their use illustrates the wider global debate about the renewed appreciation of Indigenous cultural heritage. The term 'mokomokai' combines two words in te reo. 'Moko' refers to the tattoo and 'mokai' refers to the captives (Williams 1957, 207). Even though the Williams dictionary is one of the first Māori dictionaries, the term 'mokomokai' does not appear. 'Mokomokai' has subsequently appeared in several publications since Robley in 1896, it refers primarily to the heads uniquely prepared for trade and does not cover the range of circumstances for which heads were preserved. According to Aranui and reflecting the presence of this term in most Māori dictionaries, the term 'mokamokai', was most likely used previously, this term might also be the result of a difference in dialect (Aranui 2018, 193).

The most recent term 'Toi moko', however, refers to all preserved Māori heads. In order to reestablish the entire journeys of Māori preserved heads in New Zealand and overseas, the term 
'Toi moko' appeared to be the most appropriate term to describe Māori preserved heads. 'Toi moko' was used by Māui Pōmare in the 1980s and referred to all dried heads, tattooed or not and of any social status. Aranui (2018) explains why Māui Pōmare used this specific term to define heads:

Pōmare explains that the term Toi moko was used by his grandfather "with reference to tattooed heads, and his medical research related to them". He believes "the reference to be sensitive and appropriate for the naming of the tattooed heads and in the absence of any other authoritative name I would recommend that we use it universally" (Pōmare 1993). He goes further to explain what Toi moko referred to; 'toi' meaning source, origins, beginnings, and knowledge, which are "all thinking from the head". And 'moko' referring to tattoo and special art (Pōmare In Aranui 2018, 139140)

This term reinforces the primary consideration of these heads as human, as ancestors, according to the current application of tikanga Māori. Debates have persisted among New Zealand academics and researchers about the spelling of the term. For some Māori researchers, Toi moko should be spelt with a capital $\mathrm{T}$ at all times, not just at the beginning of each sentence. Te Papa and KARP for example choose this form because Maui Pōmare used to write Toi moko this way in all his reports. Even if it is a grammatical mistake, this choice is a way for KARP to acknowledge the leadership of the former chair of the National Museum's council in the return of human remains. In France, the use of Toi moko more than moko/mokamokai can also explain the process of increasing understanding and awareness through the role of KARP and the interaction with New Zealand museum professionals. Most curators and French museum professionals initially used the term 'mokomokai' in order to define all Māori heads. The first connection with New Zealand authorities and staff from KARP at the Embassy in Paris helped French museums to understand the meaning implied by this term and to change to a more ethical approach to the issue by using the modern term of Toi moko. Repatriation is not essentially about the past, and particularly not a past transformed by written testimonies. This process is also about mutual understanding.

\section{Conclusion}

This chapter has illustrated the evolution of the different values of Toi moko since the time they were considered to be museum objects in French collections. The changing values and 
different perspectives on Toi moko reflect the dynamic contemporary position of French museum professionals regarding such treasures. The former assumptions made about Māori cultural values and what westerners called "savages" led to understandings of repatriation which were unclear and muddled. In this chapter the research I undertook on the Toi moko held in Rouen and Montpellier made me think about the importance of clarifying the historical and heritage values of Toi moko in order to properly acknowledge repatriation itself. Returning without knowing is not the solution. Both sides (French and Māori) need to know more about Toi moko preservation, use, acquisition, collection, respectful terminology and so on. Moreover, the diversity of cities and types of museums and public institutions located all over France which were involved in the acquisition of Toi moko demonstrates the conflicts of interest built up through the years and brought to light during the negotiations over their return.

As soon as I started to work on the issue of repatriation, archival research using historical sources seemed obligatory so as to illuminate the dark histories of colonisation, trade, complex collection histories and mis-representations of the Other based on European notions of race, civilisation and progress. In 2009, one of my first missions was to gain better insight into the trade in New Zealand but also into the journeys of Toi moko to French museums. I had to contact all museums in francophone countries that might have had Toi moko in their collections and started some research on their acquisition. In 2012, due to my research, KARP had a better sense of the acquisitions held by the different museums involved in the process of negotiation.

The detailed research on such topics, as this chapter demonstrates, is laborious and may not offer the results expected. I mean here that the identity of each deceased could be lost through time because the French did not place much importance on the names of Māori dead persons. Identity could be lost also through the movements of the collector throughout life and between regions and through the influence of the art market, demonstrated by the acquisition of a Toi moko by a store before it was donated to a museum.

Because the process of repatriation appeared arduous and full of complexities, choices have been made to make the discussions between France and New Zealand easier but also among French persons connected with the process of return. The example presented in this chapter of the research on Drouet, the donator of Toi moko formerly preserved in Rouen, reflects this long-term effort to find out more despite the scant archival evidence. In 
this case, however, enough data has been discovered to conjecture and theorise, but no results yet are quite sufficient to link these ancestral remains with one local iwi in New Zealand. And yet, this result, although limited, appeared to be a key factor in the return of the ancestral remains.

According to the legal procedure, the return of ancestral remains can be accomplished if the name of the deceased is known. Even though research on donors and acquisitions by museums may appear insufficient at present, research like that presented in this thesis gives us more tools to trace, understand and reflect upon the global journey of Toi moko in the past both in New Zealand and in France. This chapter therefore advances my argument by providing a greater understanding of the evolving meanings constructed by museum professionals and academic researchers associated with Toi moko.

In addition, the chapter outlines the changing French understanding of the historical evolution of Toi moko and its part in the contemporary decision to return them to New Zealand. This growing appreciation has helped the repatriation decision-makers to have a broader understanding of the historical and contemporary values of Toi moko in both France and New Zealand. This research has, therefore, already played a role in the contemporary French debate about concepts such as ownership, the ethics of ethnographic museum collections, the duty of memory in relation to the colonial period and future collaboration with Indigenous groups in museums. The next chapter, building on this, focuses on the contemporary value of Toi moko in New Zealand and on the way that museums today are organised in such a way as to explicitly facilitate their return to their land of origin. It focuses on the role of museums in the preservation of Indigenous cultural heritage, both tangible and intangible, and the part museums play in the repatriation process in New Zealand. This analysis contributes to a better understanding of the repatriation policy as it is applied in New Zealand today and of the reason that the KARP repatriation programme was located within the national museum. 
Part II

Repatriation:

From theory to a recognised museum practice 


\title{
Chapter Three
}

\section{Kaitiakitanga and Mana Taonga:}

\author{
"Museums are guardians"
}

\section{Introduction}

The last two chapters looked at the changing status and meaning of Toi moko during their long journeys from New Zealand during the Musket Wars, their acquisition by European explorers and their subsequent donation to French museum collections. The research revealed multiple contextual cases of acquisition according to the place, the different persons involved, and the variety of museums interested in their acquisition, all of which demonstrate the multiplicity of motivations that have characterised the trade in Toi moko and their changing role over the years.

Understanding how the Toi moko got to France was one element that enlightened the French negotiators involved with repatriation requests. This chapter turns to consider the other barrier to advancing repatriation requests, namely, repatriation in current New Zealand museum practice. During the negotiations for the return of Toi moko in recent years, French authorities put some importance on understanding repatriation policy as it was applied in New Zealand. Through this process, it was recognised that a national repatriation policy and genuine engagement with Indigenous values was essential. This attempt at recognition was also evident in my personal experience of this process. At the end of my first internship, I was called to the office of the French senate representatives in order to confirm the data presented in my research file sent to Senator Catherine Morin Desailly. All this work was aimed at providing a better understanding of how repatriation is practised in New Zealand museums and more particularly within the national museum Te Papa. This engagement by French politicians and museum staff with New Zealand has been important in initiating and facilitating the completion of returns. Thanks to the successful mediation and negotiations between France and New Zealand, French museums gained a better idea of the processes, practices and techniques employed in foreign museums. In this case, the involvement of a foreign national museum like Te Papa helped French authorities to favour the idea of returns. 
This experience led me to think: How has repatriation as a practice been encouraged in new museum policy? How has mutual engagement internationally helped national authorities (in this case the French Senate and New Zealand's Ministry for Culture and Heritage) understand the stakes of such operations as perceived locally by iwi and internationally by foreign museums? In this chapter, I analyse the repatriation policy, its application inside KARP and its correlation with the policy of biculturalism advocated by Te Papa. The first section of the chapter is an analysis of bicultural principles in the national museum and the influence of mātauranga Māori in its creation. The second section suggests that the timeless relations between mātauranga Māori and taonga are also reflected in the practice of repatriating ancestral remains. Sections three and four develop the concept of guardianship or kaitiakitanga not only for taonga but also for the preservation of Toi moko and kōiwi tangata. In this section, I show the application of repatriation theory in museum practice in relation to biculturalism and how the process of indigenisation shapes the repatriation process as practised by KARP through its collaboration and engagement with iwi.

Although the first attempt at repatriation in Rouen was cancelled by the French Ministry of Culture in 2007, we saw how important it was that government and legal representatives supported the successful completion of repatriation. The New Zealand examples, which are documented in this chapter, helped those on the French side to understand the high stakes of Indigenous recognition which were an important part of operations. The growing policy and practice of repatriation is therefore an example of the increasing influence of Indigenous values on the mainstream museum environment not just in the Pacific but in Europe.

\subsection{The foundation of the Museum of New Zealand Te Papa Tongarewa}

The concept of guardianship or kaitiakitanga expressed above by Te Papa Kaihautū Arapata Hakiwai demonstrates another approach to repatriation in terms of ownership and preservation of collections inside a museum. Kaitiakitanga is a modern expression for the action of protecting, conserving and caring for taonga. The word 'tiaki' is defined as the act of keeping, protecting, caring for, nourishing and sheltering (Royal n.d; Arapata et al 2018). This word can also be understood as holding under trust and administering for others (maoridictionary.com). ${ }^{10}$ By adding the prefix 'kai' referring to a person who carries out an

\footnotetext{
${ }^{10}$ Māori dictionary, tiaki :

http://www.maoridictionary.co.nz/search?idiom=\&phrase=\&proverb=\&loan=\&keywords=tiaki\&search=
} 
action for good, a kaitiaki is a person or a group who acts as protector, conservator or guardian of a taonga.

Tikanga that we use for repatriation, what we are doing during a repatriation and afterwards, but also just in day to day, by dealing with human remains, the way that we stored them. That is all involving tikanga, but I would not have experienced otherwise. Yeah, very much, my actual understanding of tikanga is coming from my work and that my work has opened my eyes to it. (Coralie O’Hara, interview by author, 23 May 2019, 12'min)

Coralie O'Hara is the Tuitui Rangahau Repatriation Coordinator and researcher at Tāmaki Paenga Hira Auckland War Memorial Museum. Even though she has pākehā origins, she is caring for Māori human remains and their return to their final resting place. Above, she describes her individual experience with tikanga in her work environment and how meaningful it is on a daily basis. This role of guardian constitutes an important function for tribal authorities in New Zealand and consequently in museums. It is an expression of guardianship which allows Indigenous voices to be represented inside a museum without being excluded from the decisions about taonga. The mission of taking care of collections can be accomplished by professionals who have a sound understanding of Māori concepts applied to Māori collections.

Although the national museum in Wellington is a prominent symbol of the 'bicultural' style of New Zealand museology, other museums in the country apply similar policies in terms of relationships with local Indigenous authorities. Bicultural policy today requires direct collaboration with the iwi and their involvement in internal operations. The concept of ownership is thus transformed into a collaborative method which combines traditional museological processes and Indigenous principles. However, not all museums apply this inclusive policy on the same terms. Some museums still present and preserve their Māori collections only according to Western thoughts and the Eurocentric 'old' museography. As Charles Royal puts it: "Kaitiakitanga today expresses traditional ideas in a time of cultural and environmental renewal" (Charles Royal n.d, 1). This quality of kaitiakitanga or guardianship can thus be granted to a group or a single individual. It can also be attributed to an establishment or association which is trying to act for the protection of values it is founded on. Kaitiakitanga is one principle of the bicultural policy at Te Papa and recognises the authority of Māori tribes or partners in the preservation of taonga: 
The recognition of the museum as a guardian rather than an uncontested owner, or even a contested owner, is very important. We could express that even more strongly to our Māori partners, but I think we have gone some way in creating this climate of trust and in some way it's a complete shift that 'we own it, we do the research, we're in control here' attitude to recognising the authority of iwi. (Seddon Bennington in McCarthy 2011, 115)

Consequently, these changes towards bicultural museum practice have led to new interpretations of the role of kaitiaki within museums. The staff at Te Papa are considered the guardians of the taonga tuku iho but also the guardians of those whose whakapapa has been lost or is not known. Herein, lies one of the controversies concerning the function of kaitiaki in the museum sector because some of these objects were not given with the approval of their affiliated iwi. In some cases, museums consider themselves to be the owners if no proof of tribal affiliation can be found, or in any cases where immoral acquisition is recognised.

The wharenui Te Hau ki Tūranga is representative of this debate on the concept of guardianship. This whare whakairo (carved meeting house) has a difficult history and is considered to have been usurped by the former Colonial Museum the predecessor of Te Papa, which is why the iwi of origin, Rongowhakaata, has requested its return to its home territory. After years of negotiation and the settlement of a claim to the Waitangi Tribunal, the original components of the whare are expected to be returned to Rongowhakaata. Nevertheless the exhibition helped the iwi to get closer to Te Papa in terms of museum practice and negotiations. By this action, Te Papa acknowledges its role of guardian to the taonga of the iwi of origin.

Now they have to figure it out what is the return look like physically? What does it look like economically? This is the thing that distraction that comes with colonial intervention is it doesn't just disrupt the life of the taonga, it's disrupted the time and space. (Cairns, 44'min)

Since the 1980s, Māori who work in the cultural sector and more particularly museums have developed a role or job description known as kaitiaki Māori. In order to define themselves as such in the museum sector, individuals must have several qualities described in the report of National Services Te Paerangi: 
The report identifies qualities such as respect, networking, sensitivity, manaakitanga or hospitality, kindness and support. It also mentions working at the interface of Māori and the museum, an understanding of the Treaty of Waitangi and an ability to participate in marae processes. Specific competencies include knowledge of tikanga Māori, Māori customs, proper pronunciation of te reo Māori, Māori language, and a level of understanding of kaupapa Māori or Māori issues and concerns. (McCarthy 2011, 105)

These relations between museum staff and tribes are the foundation of this role of kaitiakitanga. Objects are preserved or presented to the public with the agreement of the tribal authorities while curators relay information provided by the community of origin. The creation of such professional profiles reflects the contemporary role of museums in the postcolonial period. Defining an institution as a kaitiaki requires a reassessment of the ontological definition of a museum. In the interview, Māori staff member Puawai Cairns explained this arrangement as follows:

I sometimes explain to people the difficulty of repatriating Te Hau ki Tūranga back to Gisborne. Same with those bones, same with any taonga that comes back. Because Māori didn't have a sense of permanent when it came with taonga. Taonga was created, they lived with people time and then they died. They were burned, left to rot, sometime pass down to generation but the permanence was never a thing. Museum are operating a completely different understanding of time. Those things are dealing with stuff that have been taking away from its original context and you are trying to reintroduce back to what you consider its original context, but that doesn't exist anymore. It didn't exist a week after it was taken. So, it is a little unfair that the French are angry because to reconnect the kōiwi or the upoko back to its people is not an easy thing, is not a thing that could be done just like that. It is something that could possibly take another hundred years. It is not truly their fault over an institution trying to bring these things back, it is because it takes a long time to recover from these temporal, special disruption." (Cairns, 45 'min)

As we can see from these comments, professional practice in museums like Te Papa and the Auckland Museum reflects a new relationship with ancestral treasures in modern society. 
Taonga are not only about the past but also reflect a continuous connection with their local communities in the present and this sense of a continuum is implemented in operational procedures within institutions like museums, galleries and archives throughout New Zealand. Museums are now places where taonga can be preserved and treasured and exhibited to the general public according to Māori values and perspectives. In pre-European society, taonga were preserved, according to Indigenous knowledge, but today museums have to be places where Māori knowledge and Western conditions of preservation work together in order to present this heritage to the next generations.

However, despite the advances of bicultural policy, the process of returning human remains can still be difficult and tiresome and may need detailed planning between the two parties before beginning the process. As explained by Laura Peers $(2017,9-21)$ repatriation is also the combining of Indigenous protocols with Western bureaucracy in order to successfully complete the process, according to Western laws and Indigenous customs. The value given to a taonga is also evolving and changing as is the case with other aspects of Māori cultural heritage which is not static but dynamic and changing. Museums do not have to answer questions that communities of origin can answer by themselves. Taonga should be defined by Māori representatives who assist museums to transmit their knowledge to the public. That is why repatriation is a process of partnership and collaboration that theoretically must be completed by both sides, dissolving any ratio of power between Indigenous and French museum professionals.

\subsubsection{The importance of the Te Mãori exhibition}

The exhibition Te Mãori symbolises the recognition of Māori knowledge in the museum sector. During the 1980s, this exhibition echoed the political and social debates that developed at that time. Movements towards Māori independence and self-determination were already widespread nationally beforehand thanks to various actions carried out such as the constitution of the Waitangi Tribunal or even the events of Bastion Point between 1977 and 1978. The secretary of Māori Affairs at the end of the 1980s, Kara Puketapu, intended to generate a cultural event to promote interest by the younger generations in the continuity of Indigenous values and knowledge (Ministry for Culture and Heritage, 8 November 2015). This exhibition is still considered to be a model of the use and interpretations of taonga by Māori themselves. Te Māori was part of a renewed interest in the development of cultural identity, always driven by this feeling of tino rangatiratanga, self-determination. Te Māori 
embodied for the first time an Indigenous vision of the preservation and exposition of the Indigenous people's own treasures. It is still presented today as a pioneer when it comes to international Indigenous exhibitions and also marked the beginning of bicultural museum practice. It was developed with the aim of presenting these collections to a foreign audience for the first time. The exhibition toured the United States between 1984 and 1987 where it received notable success in every city in which it was presented. More than 600,000 people saw the exhibition in the four museums that programmed it: the Metropolitan Museum of Art in New York, the Saint Louis Art Museum, the M.H de Young Museum in San Francisco and finally the Field Museum in Chicago. A Māori delegation accompanied by kaumātua formed the group who escorted the treasures.

By applying Indigenous protocols, thereby maintaining their tapu, the delegation also demonstrated the contemporary relevance of such knowledge and its perennial transmission in New Zealand. One mission of this delegation was to inform the teams of museums they visited about the protocols that were in force as a result of the presence of taonga in their galleries. In parallel, during the exhibition's tour of North American cities, the Māori team discussed with the American professional museum teams the care of the Māori collections held in their own permanent collections. They did not intend to take them back but simply to pass on information on how to look after them sensitively and according to the Indigenous identity. On its return to New Zealand in 1986, the exhibition gained the title Te Mãori: Te Hokinga Mai and travelled through New Zealand and was visited by nearly 920,000 people. It travelled first to the National Museum in Wellington, then to the Otago Museum in Dunedin, the Robert McDougall Art Gallery in Christchurch and finally the Auckland City Art Gallery. Te Hokinga Mai is also the name of a well-known waiata written especially for the exhibition. The version performed by Pakipaki Bilingual School (currently named Te Kura o Paki Paki) in Hastings was first sung upon the return of the Te Mãori exhibition to Aotearoa. This same song is still performed during the repatriation ceremonies.

In the past, the most common way to exhibit Indigenous treasures in Western establishments isolated them from their primary definitions or functions. They were considered to be no longer functional objects but only artistic or decorative. Te Māori introduced a way of appreciating the Indigenous relationships with the taonga. Rather than being considered as an outdated aspect of a culture in decline, the position of Māori expert became recognised as a scientific/curatorial support in terms of museology and preservation (Mead 1986; McCarthy 2011). In 1979, during the first negotiations between the United States and New Zealand 
governments concerning the exhibition tour, it was noted that the Queen Elizabeth II Arts Council had developed a proposal directed towards collections of artworks rather than simple 'objects' (Ministry for Culture and Heritage, 8 November 2015).

In his book devoted to the role the exhibition played in contemporary Māori cultural identity, Hirini Moko Mead shares the multiple meanings and repercussions that the exhibition aroused at each place it visited and more particularly at the Metropolitan Museum of Art in New York:

The Metropolitan is synonymous with international art. It is the centre of the world of art. By taking our art to New York, we altered its status and changed overnight the perception of it by people at home and abroad. We brought Maori art out of the closet, out from obscurity, out from anonymity, and out of the cupboard of primitive contextualisation. In fact, we rescued it and freed it from the limiting intellectual climate of New Zealand, releasing it so it could be seen by the world. (Mead 1986, 11)

This cross-cultural policy still encounters some resistance today, however, it is clear that the impact this exhibition had on the administrative model now operated by Te Papa was decisive. Through the active participation of iwi and the protocols applied to taonga, this exhibition demonstrated that it was possible to compose a curatorial policy presenting the characteristics of both the museum's ontology and Indigenous heritage. David Butts relates this inspiration and the continuity of the work proposed by Te Mãori in his research more than 10 years after the exhibition.

Te Maori continues to be a focus for scholars interested in the evolving relationships between Māori and museums...Tribal kaitiakitanga (customary practices relating to guardianship and authority over taonga) were recognised by museums during Te Maori, and consequently this recognition has been taken into individual institutional negotiations with tribes at the local level. Nowhere was this more evident than in the planning for the Museum of New Zealand Te Papa Tongarewa. (Butts 2003, 89)

Following the impulse of the exhibition, another result of the increasing participation of the Māori community in museum activities has been the growing numbers of repatriation requests from the 1980s. Māui Pōmare led several repatriations during the same decade. As a result, several regional museums, including those in Christchurch, Hamilton, Dunedin, Tauranga and 
the National Museum in Wellington (Te Papa's predecessor) and the Auckland War Memorial Museum have all been asked to return human remains and some taonga to Māori groups. Knowledge of Indigenous cultural identity and its application in the cultural sector has naturally generated this wave of demands which today is mandated by the New Zealand Government and, as this thesis shows, is expanding in to an international scale.

\subsubsection{Te Papa Our Place, also a place for all tribal perspectives}

Through this emerging international consideration for Indigenous collections, biculturalism has been conceptualised and applied to the museum sector. Founded on the articles of the Treaty of Waitangi and the success of the Te Māori exhibition, Te Papa's biculturalism recognises the political and cultural place of New Zealand's Indigenous community:

Te Papa's concept is founded on:

Papatūānuku - the earth on which we all live;

Tangata Whenua - those who belong to the land by right of first discovery;

Tangata Tiriti - those who belong to the land by right of the Treaty of Waitangi;

The concept encompasses:

Unified collections;

The narratives of culture and place;

The idea of forum;

The bicultural partnership between Tangata Whenua and Tangata Tiriti;

The multidisciplinary approach to delivering a national museum for diverse audiences. (Annual Report of the Museum of New Zealand Te Papa Tongarewa 2008-2009, 2009-2010, 2011-2012)

Inside Te Papa, Māori treasures are understood as taonga, a shift in meaning which is correlated with the museological changes. The collaboration between museums and Māori valorised Māori perspectives on their collections by recognising their original function and meaning. This museological changes, still recent, requires the renewal of conservation standards in connection with the community of origin: 
This encompasses wise management, spiritual and cultural care and protection. Te Papa acknowledges that it holds collections in trust for the people of Aotearoa New Zealand and the responsibility to protect and care for them for present and future generations. Te Papa acknowledges and respects the whakapapa (genealogical) relationships between taonga and their communities and the knowledge that arises from them. (Museum of New Zealand Te Papa Tongarewa Statement of Intent 2012/13, 2013/14, 2014/15, p.6, accessed 6 May 2015)

Occupying a space of almost two hectares, Te Papa brings together and manages heterogeneous collections: contemporary arts, specimens of natural history or objects from the Pacific and overseas countries and, last but not least, Māori collections. These taonga trace the evolution of Māori cultural identity from pre-European times to the present day. Māori collections are not just composed of historical objects in the temporal sense of the term. The collections also include contemporary art pieces such as Shane Cotton's paintings representing Toi moko figures. This continuous aspect of material culture at Te Papa is a key part of the relationships between the museum and Māori. Te Papa has been the subject of several debates and controversies concerning its management of taonga Māori over the last twenty plus years, but the museum tries to maintain beneficial relationships for both Treaty partners, Māori and the Crown. The website declares that "Te Papa is New Zealand's national museum, renowned for being bicultural, scholarly, innovative, and fun. Our success is built on our relationships with and ability to represent our community" (Te Papa website, about us, 2018).

Since its opening in 1998, the museum has resolutely put its bicultural theories into practice, for example, exhibitions dedicated to the history of one iwi in which taonga affiliated with that iwi has been exhibited for a certain period of time. Every exhibition of this type is important because of its meaning in terms of the bicultural policy but also in terms of the length of time. Each exhibition is presented for at least two years. Each iwi chooses a delegation with whom Te Papa's staff work on the selection of taonga, sharing of the knowledge related to them and the creation of exhibition. This delegation is directly representative of the iwi.

These exhibitions are considered to be developed in partnership and essential to the museum's creativity and function. Moreover, they are sometimes the first and only experience with 
Māori culture for many foreign tourists who come to visit New Zealand. Research suggests these displays may indeed have an indirect impact on tourists global understanding of Māori cultural perspectives. One of the aims of iwi exhibitions is to learn more about specific tribes and to gain a better understanding of Māori culture in its diversity. Therefore, Te Papa's iwi exhibitions provide opportunities to learn about Māori communities today by exposing visitors to the treasures of one iwi which reinforce the sense of richness, strength and diversity of the Indigenous culture of Aotearoa.

Table 2: Iwi exhibition presented at Te Papa since its creation.

\begin{tabular}{|c|c|}
\hline Name of the exhibition & Time of exhibition \\
\hline $\begin{array}{l}\text { Ko Rongowhakaata - ruku I te pō, ruku I } \\
\text { te ao. }\end{array}$ & 29 September 2017-today \\
\hline $\begin{array}{l}\text { Whiti te Rā! The story of Ngāti Toa } \\
\text { Rangatira }\end{array}$ & 4 June 2014-17 March 2017 \\
\hline $\begin{array}{l}\text { Tai timu, tai pari, Tainui: Journey of a } \\
\text { people }\end{array}$ & 3 September 2011-2 March 2014 \\
\hline $\begin{array}{l}\text { Mō Tātou: The Ngāi Tahu Whānui } \\
\text { Exhibition }\end{array}$ & 8 July 2006-9 August 2009 \\
\hline Te Awa Tupua: The Whanganui Iwi & 29 November 2003-27 May 2006 \\
\hline Tühoe: Children of the Mist & November 2001-3 November 2003 \\
\hline $\begin{array}{l}\text { Te Aupouri Iwi: People of Smoke and } \\
\text { Flame }\end{array}$ & August 1999-October 2001 \\
\hline Te Ātiawa & February 1998-August 1999 \\
\hline
\end{tabular}

Each tribe's participation in museum activities during the exhibition period resides not only in the exhibition but also in the daily life of the museum. Kaumātua from the tribe sit with the staff to guide Māori activities during the period of their iwi exhibition. Kaumātua have the opportunity to work with the different teams working on the conservation of taonga and to give their advice and perspective in museum activities. The status of kaumātua gives them an aura that invites the different members of the museum to take their time to share their state of mind. Kaumātua can also teach waiata to the museum staff during the weekly practice sessions. Those songs are used later during events at the museum. In this way, kaumātua become the museum's representatives or speakers for all the ceremonies taking place at the museum, such as exhibition opening ceremonies, pōwhiri or welcomes, and, of course, repatriation ceremonies. In France, different kaumātua were present in 2007 and from 2010 to 2011 during the various ceremonies conducted in Rouen and Paris for Toi moko or the poupou Titokowaru. 
The re-definition of the national museum as the guardian of Indigenous collections does not reflect the contemporary world in which the Māori community lives or wider New Zealand society where racism and other social problems are still very marked. The ideal bicultural vision of Te Papa is not representative of New Zealand society as a whole in which Māori and Pākehā do not yet share equal status. The hiring of Māori staff with the qualifications to protect the collections has had repercussions. With Pākehā authority called into question by this hiring policy, certain curators or museum administrators have viewed sourly the promotion of Indigenous positions within the museum (Schubert-McArthur 2019). Consequently, Te Papa has often been criticised for inconsistencies in exhibits or that the institution does not react in the same way to Pākehā or Māori sensitivities (Atkinson 2009). According to some sceptical analysts, Te Papa is trying to build an "artificial Biculturalism" (Williams 2005, 94).

\subsubsection{Biculturalism at Te Papa}

$[\ldots]$ the museums are constrained by their own history, where they come from, they want to break out of it, and create more spaces. And I think Te Papa's experience in creating a national museum which is totally different from what its precedent was. And set up sort of how it recognises the role of Māori as tangata whenua but also the role of communities are playing in museums. (Hakiwai, Interview by author, Wellington, 9 April 2019, 11 'min)

The development of Indigenous perspectives on Indigenous museum collections reflects the post-colonial status of such institutions today. In order to encourage the Western public to understand a more Indigenous perspective from other parts of the world, museums are not just working with anthropologists but also with native communities. This inclusive method is part of an approach that renews spiritual ties between people and things and includes those elements in contemporary definitions of cultural identity by and for descendants. In the New Zealand context, for example, this movement helped each iwi involved in exhibitions at Te Papa to reconnect with their treasures in order to learn about the past and to transmit this knowledge to the next generation. Because most of these objects have been transported to museums since the 19th century, they have been geographically and spiritually removed from their initial functions. Jonathan Mane-Wheoki has described these formal Western-centred ethnographic exhibitions as "brown art in white spaces" (Mane-Wheoki 1996, 43). Over the 
last 30 years, Māori have become more aware of the future of their treasures, and the integration of Indigenous museum positions regarding their conservation has provided a new impetus to Indigenous interest in museums. Consequently, museology and conservation have been significantly reformed since the establishment of museums in New Zealand in the 19th century. McCarthy makes this point about Māori exhibitions, quoting David Butt's memories of the 1970s and early 1980s:

Māori collections and displays were generally arranged and presented according to the disciplinary framework of ethnology and archaeology and there is not much evidence of input from Māori people. David Butts remembers the Māori halls in the major museums:

"The Exhibition cases were full of taonga, usually organized typologically or functionally and usually with little reference to the provenance of the taonga or the history of iwi Māori either prior to European settlement or in more contemporary periods". (McCarthy 2011, 39)

This testimony gives us a better understanding of the global way of seeing these taonga in the museums of New Zealand in the second half of the 20th century. Combined with my observations of museums in both countries, this comment also helps me to conceive some museological analogies between museum practice in contemporary France and New Zealand pre-Te Māori. A neo-colonial museology is still applied to taonga exhibited in the galleries of some Western museums today. Information about each object is just as modest as that provided by most New Zealand galleries in the 1970s. Māori have often criticised and challenged the unethical or 'forgotten context' of acquisition and the 'cold' and bare way in which artifacts are presented. They consider this type of display inadequate for the value of the taonga and their spiritual strength. By providing little information on the history of the object and consequently of the tribe to which it belongs, museums are not acknowledging the importance of the past in contemporary cultural identity (Mead 1986, Butts 2003, Tapsell 2005, McCarthy 2007; 2011, Waitangi tribunal 2011).

Some academics like Gerard O'Regan (1997), and Butts in his thesis in 2003, have also attempted to demonstrate the differences between a simple partnership and tino rangatiratanga when it comes to paying attention to museum collections. 
In drawing attention to the significance of cultural recognition, O'Regan also exposes the insidious nature of bicultural rhetoric. Institutional biculturalism is often applied like makeup: it can create the appearance desired by both the wearer and the viewer, while beneath the surface the ravages of time remain. In the case of museums, the inherited ideologies of western museology may be covered up for public consumption, but after the performance, when the makeup is cleaned off, the old face remains as it has always been, the face of colonialism (Butts 2003, 94).

In this context, museums are defined as lifeless places, dead houses (Sciascia 2012). These comments are more troubling when they are made about the storage conditions deemed inappropriate for collections as controversial as human remains. Catherine Morin Desailly mentioned during her interview that Philippe Richert, senator in charge of the law proposed for the repatriation of Saartje Baartman, was scandalised when he discovered the condition of some human remains stored in French museums (Morin Desailly 2019, 13'min). Those comments can also be applied to the lack of preservation of some Toi moko. They may have suffered deterioration due to poor conditions over the long term with too high a humidity level without prior protection, a large amount of dust, coarse storage materials (trash bags, cellophane, etc.) or even attacks by insects and animals (such as rodents).

Despite these parallels, the lack of information about taonga in New Zealand museums before the late 1980s shows us how fragile the knowledge transmission was and remains in some museums. We can nevertheless notice an improvement in the key role of Indigenous professionals even though underlying inequalities and balance of power still persist. The 1990s was the decade of a series of negotiations between the Crown and Māori which asserted the role of native people in public space. Those discussions are the results of previous actions such as the Treaty of Waitangi Act of 1975, the exhibition Te Mãori in the 1980s and the creation of the new national museum Te Papa. It was in 1992 that the museum's construction project was first mentioned. Discussions were centred on the possible bicultural foundations of such infrastructure.

Māori began organising themselves within the museum sector. Hirini (Sidney) Mead and Te Aue Davis established the Te Māori Manaaki Taonga Trust to assist museum-related scholarship. Mina McKenzie and Bill Cooper organised Māori employees as a professional body named 
Kaitiaki Māori (Māori Museum Workers), which, in 1992, joined the newly constituted Museums Association of Aotearoa New Zealand (MAANZ).

These moves helped establish a national code of ethics, encouraging the involvement of local elders and better interpretation of taonga in museums. By the mid-1990s, kaumātua advisory committees were created throughout the sector. (Tapsell 2014, 4)

The biculturalism applied at Te Papa was reflected in the separate management of Indigenous on organisational chart: one under the chief executive and the other under the authority of the kaihautū. But McCarthy shows that Te Papa received negative comments on its administration due to the tendency of traditional Māori culture. In addition, Te Papa was accused of constructing a bicultural model that would absorb the Māori culture in a postsettler state without reflecting its aspiration for self-determination:

Academic attacks on biculturalism have to be treated with caution; they are often superficial, subjective and rarely grounded in current practice. Invoking the invention of tradition and identity politics is all very well, but indigenous efforts to regain control of their heritage cannot be explained away by branding them 'theoretically incorrect'. Much of the anti-bicultural writing is a local application of the international literature on the construction of national identity in former settler colonies in which museums, monuments and sites are said to homogenise difference, even as they attempt to include indigenous peoples in national memory and public history. (McCarthy 2012, 231)

The system proposed by Te Papa is not yet accepted by all academics. Several years after its opening, Hamish Keith was one of the most fervent opponents of the idea of this museum and especially of the way of exhibiting the Māori and Pākehā collections. He complained that:

For some odd reason the curators of Te Papa, despite their pleas that the new museology never displayed works of art forever, confined these adventures to the European and Pakeha collections. Many of the great Maori works such as Te Hau-Ki-Turanga remained permanently installed, as they have since the original institution opened in 1936. (Keith 2001, 14) 
Contemporary configuration of museum management applied at Te Papa had to reconcile national identity and the role of the Māori identity within it. That is the reason why, according to the principles of the Treaty of Waitangi, Te Papa had to express the roles of the Tangata Whenua and the Tangata Tiriti used in the museum's policy as follows:

Biculturalism at Te Papa is the partnership between Tangata Whenua and Tangata Tiriti recognising the legislative, conceptual and Treaty framework within which the Museum operates as well as reflecting international developments. This framework provides the mandate for the Museum to express and celebrate the natural and cultural diversity of New Zealand. It acknowledges the unique position of Māori in Aotearoa New Zealand and the need to secure their participation in the governance, management, and operation of the Museum of New Zealand Te Papa Tongarewa. (Te Papa Annual Reports 2008/9, cited in McCarthy 2011, 114)

Tangata Whenua refers to the 'people of the land', the Indigenous and first community who arrived in New Zealand. It is with the notion of Tangata Tiriti (people of the treaty) that the controversies have arisen. This term from te reo Māori designates individuals who live in New Zealand by right of the Treaty of Waitangi. Formerly, the predominant British settlers may have been designated by this Māori word but today New Zealand is home to people from different regions of the world, and different nations. Tangata Tiriti is consequently used for any non-Māori who live in the country. In response to this, the government chose to promote recognition of cultural diversity through an expression that is repeatedly used: "One nation, two peoples, many cultures":

In other words, beyond the One, the Two and the Many there are complex articulations, different imaginaries of New Zealand social space, different senses of closure that mark repressed histories of colonisation, racial violence, the trauma of colonial settler society and separation from imaginary homelands, immigration control, discrimination and so on.

(Božić-Vrbančić 2003, 295-313)

The ambivalence of the terms biculturalism and multiculturalism is still the subject of debates. Some individuals advocate multiculturalism to encompass all the cultures present, others prefer to develop an interaction between the two most represented communities in New Zealand in accordance with the criteria of the Treaty of Waitangi and then promote 
representations of other identities. Ranginui Walker, in favour of biculturalism, points out the delicate separation between multi- and bi-culturalism: "Māori remind Pākehā that becoming bicultural enough to be at ease in the other founding culture of the nation is the first step towards becoming multicultural" (Walker 2004, 390).

This controversy, therefore, has required a re-conceptualisation of the relationships between people and land. The interaction of the three poles on which the museum was built in the early 1990s - the land, the Indigenous people and the settlers - had to be recomposed according to the context in which the idea of Te Papa evolved (Schubert McCarthur 2014, 56).

Consequently, it was decided to redefine these axes as three broader concepts: 'The Natural Environment', 'Māori' and 'Art and History', with a view to seeing the Māori collection exhibited in its entirety in accordance with the values of the community of origin.

\subsection{Acknowledging the timeless connections between Toi moko and mātauranga Māori}

\subsubsection{Whakapapa}

Every Māori, especially if he came of a good family, knew his or her genealogy and exact relationship to every relative. This was most important to a Māori. If he went to a strange place, he would only need to repeat his genealogy to make himself known to any relatives whom he might have there. Through these relatives lived the clan name of another ancestor, he and they would claim relationship through the genealogy. (Makereti 1986, 37)

Whakapapa is perhaps the most important concept in understanding or simply recognising the reasons that motivate the return of Toi moko or kōiwi tangata. This notion of whakapapa can be simply translated by the word 'genealogy' (Tapsell 2002b; Mead 2003; Hakiwai 2014). Although it has commonalities with genealogy as we hear it in Europe, it differs from it by its spiritual dimension. Whakapapa is the key concept for developing further links which bring together animate and inanimate phenomena, known or unknown in the terrestrial and celestial kingdoms (Taonui 2011, 1). Whakapapa is the principle which links tangata whenua (the people of the earth), tūpuna (ancestors), atua (ancestor with continuing influence, gods) and Papatūānuku (Mother Earth) to each other. The words 'whakapapa' and 'Papatūānuku' also have the same linguistic base. The word 'papa' can be defined as 'foundation'. Although whakapapa is regularly translated as genealogy, the literal meaning of this word is "creation 
of a base" or "foundation" (Mead 2003, 42). This term can refer to the interrelation between affiliations and stories that are the foundation of every person's identity.

In his definition of whakapapa, Hirini Moko Mead describes the attachment and pride felt to be Māori: "Whakapapa provides our identity within a tribal structure and later in life gives an individual the right to say, 'I am Māori'” (Mead 2003, 42). He continues by specifying the effects of whakapapa on identity and the rights that gives you as a member of an Indigenous group:

Whakapapa legitimises participation in hapū affairs and opens doors to the assets of the iwi. It provides a right to be buried in the local urupā (cemetery), a right to succeed to land interests of the parents and a right to claim membership in the hapū. (Mead 2003, 42)

This right to be buried in the local urupā is surely an influencing factor in the creation of the repatriation programme as we know it today. Interviewees in my research expressed the importance of whakapapa in the accomplishment of this operation. In France, repatriation was a way to acknowledge the living Māori culture and in New Zealand it is about the continuity of the commemoration of ancestors. Repatriation process emphasises the fact that everything stems from whakapapa in terms of the repatriation of tūpuna. It is the basis of tikanga (Māori customs) used in the creation of the repatriation programme, and it is considered today to be the essential element for understanding cultural identity in its broadest form. The objective of locating these human remains is to reconnect the whakapapa of the deceased to that of their groups of origin (KARP 2009b, 2012d).

The kaupapa of repatriation is associated with the whakapapa of each iwi, hapū or whānau. And every person has a different appreciation of Māori knowledge and everyone has his/her own way of learning and transmitting information. Te Rangihīroa explains the action of whakapapa on tribal society as the procedure of "putting something on another" (Hīroa 1949, 36). Whakapapa includes the names of the ancestors who make up an individual's family tree, but it also includes all their achievements and their experiences, in order to transmit memories of them to future generations. The stories of the tribal migration aboard waka are part of oral transmission. Today, access to information concerning pre-European society and first contacts appears easier than before. Research on human remains aimed at finding out their whakapapa also relies on historical facts found in written resources and oral transmission. 
Waka arrived in different regions, all over the country, from Northland to Te Wai Pounamu (Taonui 2005). Some tribes have been created by members of a single waka crew. For example, the tribes of the Waikato region ${ }^{11}$ are from the waka Tainui, the tribes of the Lake Rotorua region (Ngāti Pikiao, Tuhourangi and Ngāti Whakaue) and the tribes around Lake Taupō (Ngāti Tahu and Ngāti Tuwharetoa) are from waka Te Arawa. Finally, the tribes of Ngāti Kahungunu between Wairarapa and the South of Gisborne are attached to the waka Takitimu. There are also tribes that have formed under the authority of individuals from different canoes. Ngā Puhi, the first traces of which are in the North, originate from the Matawharoa, Ngātokimatawhaorua and Mataatua canoes. Other tribes living in different regions, however, have common affiliations with one waka.

To sum up, the notion of whakapapa in its broadest sense combines mythology, legends, history, mātauranga (knowledge) and tikanga and each individual traces a single lineage according to the family tree associated with his/her family, hapū and iwi history. This term is maybe one of the most important to understand the process of repatriation in New Zealand and its significance for Māori descendants today.

\subsubsection{He tapu ngā kōiwi tāngata/Human bones are tapu}

Tapu is commonly defined as sacred, but I like to use the definition found in the revised Williams dictionary from 1957 that defines tapu as "a condition affecting persons, places, and things, and arising from innumerable causes" (Williams 1957, 385). Hirini Moko Mead goes deeper in describing the term. He classifies the different aspects of tapu and develops four categories of tapu that characterise the "most important spiritual attribute" (Mead 2003, 45). According to him, the tapu of personal space, of the body, of the blood and finally the tapu of death, encompass the personal tapu of every person (Mead 2003, 48-49). All these last four dimensions of one's personal tapu have a paramount significance in the repatriation process. Every human being of all social and ethnic origins is tapu. His/her individual actions determine spiritual influence, mana and tapu. Whakapapa provides the link between tangata whenua and Papatūānuku through the creation and protection of, for example, urupāa Māori believe that every living thing is linked and Papatūānuku is the origin of all. We can also demonstrate this affiliation through the etymological origin of the word 'iwi'. We are

\footnotetext{
${ }^{11}$ The four main ones are Hauraki, Ngāti Maniapoto, Ngāti Raukawa and Waikato. Today there are more than twenty tribes affiliated with Tainui waka and her captain Hoturoa. (www.waikatotainui.com)
} 
particularly referring here to the speech from Hirini Moko Mead who states that the word iwi is defined at first sight as 'the tribe' but can be used to define the bones.

The word iwi may refer to bones, one's relatives. What is left of members of the iwi are their bones which are usually buried in caves in the ground. This cultural practice also creates binding relationships with the land.

(Mead 2003, 270)

The bond between iwi and mother earth is fed daily by whānau. As we said earlier, whānau or families are linked to the territories of origin through birthright. Every individual can be a member of a tribe, sub-tribe or family through his/her timeless link with the territory. The notion of whenua is first of all the word defining the earth, but it also refers to the placenta.

Ranginui Walker gives us his definition of tapu by declaring that it is a spiritual force which emanated from the celestial kingdom and from its gods (Walker 2004, 67). This genealogy is imbued with a strong tapu dimension because of the link between people of the land and the spirits. These resources are at the same time used by people in their daily lives, to demonstrate among other things their belonging and devotion to the atua (ancestors with influence or gods).

Thus, ancestors, whether from a high line or not, are included in this repatriation procedure and must return to their lands of origin. They remain men,women and children who participated in Māori society and perpetuate this role today through funeral ceremonies and wairua (spirits). This point was one of the most controversial in France during the debates on restitution. The fact of seeing the return of some ancestors who could have belonged to the lowest category of the social scale resulted in disparities of opinion in French ranks. Many captives have been victims through the traffic of their heads. Today, social status doesn't play any role in the repatriation process. Because some Toi moko in European museums are unknown, the main interest for KARP is to undertake provenance research in order to prove first of all their Māori affiliation and their tribal origin if possible

The Māori community is seen as one unified population. Every individual is identified in the contemporary environment by acknowledging his/her affiliation with iwi. Although Māori society changed dramatically with the arrival of Europeans, the tribal organisation of the community is still in place and is considered to indicate the sustainability of Indigenous culture in New Zealand. As discussed in the introduction, the idea of iwi only really gained 
widespread usage post European contact. Māori were very much hapū based communities prior to that.

\subsection{KARP as guardian of human remains}

KARP was established at Te Papa in 2003 only five years after the museum opened to the public. The programme respects and transmits Te Papa's bicultural principles and consequently respects the same rules for Toi moko as for taonga. KARP is not the owner of human remains but their guardian:

That 'Te Papa Acknowledges Mana Taonga' is one of six corporate principles informing the philosophy of Te Papa. Mana Taonga is a recognition of the power of taonga to communicate deep truths about our people. [...] Te Papa also 'recognises the role of communities in enhancing the care and understanding of collections and taonga.' Taonga in this sense embraces any cultural items of significance or value. The Mana Taonga principle guides our direction and approach to access and research.

(Te Papa website, February 2015)

Because the research undertaken by the repatriation programme is interdisciplinary and diplomatically impactful, the conditions put in place to create this programme had to be precise. Te Papa initiated several negotiations between the various parties (the ministries, the national museum and the tribal authorities) in order to present the aims of the programme and the issues with which it would be engaged. These words appear on each official letter from the programme:

- Continue to engage with the international institutions to negotiate the return of kōiwi/koimi tangata to Aotearoa, Te Waipounamu and Rekohu;

- Maintain a strong research base on kōiwi/koimi tangata, and related links with international institutions, collectors and donors, iwi, and any other research sources;

- Support a Repatriation Advisory Panel of Māori research experts and kaumātua; 
- Engage with iwi through wānanga or hui to discuss the return of kōiwi/koimi tangata;

- Five repatrations to be completed each year with a minimum of one return to iwi; and

- Maintain appropriate management of Te Papa's Wāhi Tapu.

(Karanga Aotearoa Repatriation Programme, April 2012d)

With government support, KARP also works in collaboration with national authorities such as the Customs Service, the Ministry of Agriculture, the Māori Affairs Ministry and the national airline, Air New Zealand (Karanga Aotearoa Repatriation Programme 2009a, 2012d). The collaborative work carried out by these various organisations demonstrates that significant resources have been in deployed for the success of such operation. In order to describe parts of the objectives and goals, KARP produces a series of newsletters-Te Pānui o Karanga Aotearoa-intended to raise awareness of the mission and the aims of the programme and its development. Through these newsletters, readers have the opportunity to study the current operations in which KARP plays a role, such as the restitution ceremonies, the hui ā rohe, and/or contacts with foreign institutions.

In 2003, Te Papa seemed like the ideal place to temporarily house Māori human remains until their return to their places of origin. A room is now exclusively used for the protection of repatriated Māori human remains. The programme has, thus, the opportunity to accomplish these returns in a place where sacred values towards Māori ancestors are applied.

Since 1 July 2003 until 1 May 2017, Te Papa has repatriated 420 Māori and Moriori ancestral remains from overseas institutions, including from countries such as Australia, Austria, Canada, France, Germany, Sweden, the United Kingdom and the United States of America. We estimate that there are over 600 still awaiting their homecoming. (The Karanga Aotearoa Repatriation Programme, tepapa.govt.co.nz, accessed 29 April 2020)

The temporary preservation and repatriation of Toi moko or kōiwi tangata are spearheads of the bicultural policy within the museum, between western museology and Māori policies. Although human remains do not have accession numbers, they enjoy the appropriate 
conditions of preservation in a museum until the programme returns them to their final resting places.

\subsubsection{The wāhi tapu}

Wāhi tapu, translates as 'sacred place', is a place with a high degree of tapu because of its purpose. This is the name given to the room at Te Papawhere Toi moko and kōiwi tangata are temporarily stored before returning to their final resting places. Wāhi tapu are seen as places where the tapu of those heads cannot be altered by other spiritual powers. The room also protects the living from the tapu of the dead. Like burial sites, the wāhi tapu at Te Papa isolates the tapu of human remains to a delimited space. During this period of conservation, neither Te Papa nor the government can claim to be the legitimate owner of these human remains. They apply a rigorous protocol on site regarding the conditions of preservation and handling of these remains. Indeed, access to these sacred sites is strctly limited. People whose research is useful to the community of origin or to the programme itself must be authorised by following the conditions established by the programme and tribal authorities.

I was able to enter the wāhi tapu only once in 2009. My coming inside had been approved in order to increase my knowledge of the various drying and embalming techniques. This decision in my favour had not been accepted by all the people in charge of the site. On my return in 2012, I was strictly forbidden to access this room because of the high degree of tapu of tūpuna. There are still several debates concerning entry into this room at Te Papa. Because I was KARP's first foreign intern, it seems that my experience was an opportunity to express new concerns

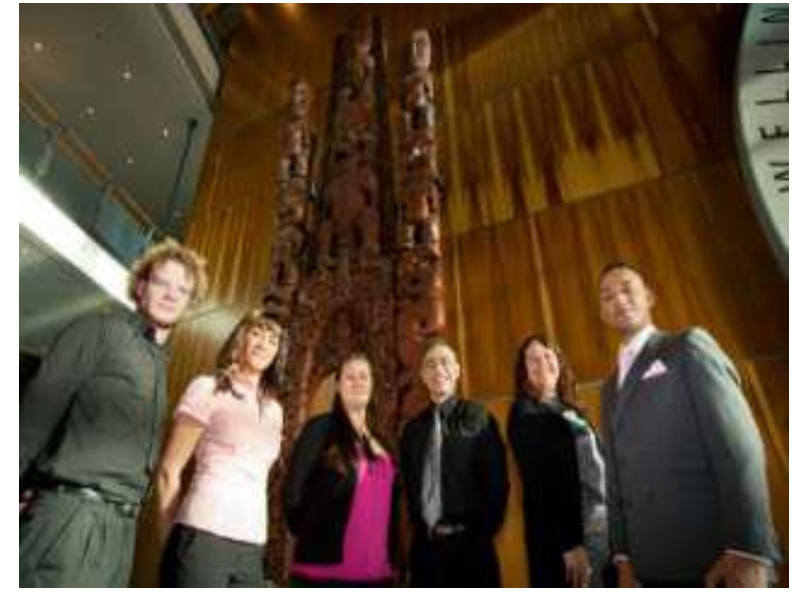

Figure 2 Karanga Aotearoa Repatration Programme in 2009. From left to right: Simon Jean, Tania Te Whenua, Amber Kiri Aranui, Te Herekiekie Herewini, Nicola Kiri Smith, Te Arikirangi Mamaku @ Norman Heke, Te Papa, 2009. about the management of the wāhi tapu. Access is mostly denied to foreigners, even to Te Papa staff who do not work for the programme. The invitation is generally granted only to the repatriation team and members of the tribes wishing to get back their ancestors or for preparing the traditional baskets (or coffins) used for ceremonies. 


\subsubsection{The Repatriation Advisory Panel (RAP)}

The RAP team main mission is to guide and advise the repatriation programme in its diverse actions, such as domestic and international operations and research. Comprising academics, mayors, linguists, tattooists, performers and kaumātua, the members are all highly regarded Māori representatives. They are experts on major aspects of mātauranga Māori in terms of customs, protocols, and traditional practices that define tangible and intangible Māori heritage. Thanks to their individual experiences, RAP members help KARP to define and to consider the concerns and expectations of each programme of research. Members of RAP also travel overseas with the repatriation delegation in order to inform foreigners on repatriation policy and to lead the ceremonies. In France, Te Kanawa and Kataraina Pitiroi went to Rouen in order to lead the ceremony and Derek Lardelli went to Paris eight months later to speak during the pōwhiri held at MQB-JC.

The panel is invited to gather several times a year at Te Papa to discuss the next actions of the programme or any major topic that needs to be clarified such as unprovenanced human remains and the project of a national resting place. As at the time of writing, the seven current members of RAP were: Pou Temara, chairman; Te Kanawa Pitiroi; Hokimoana Te RikaHekerangi; Derek Lardelli; Aroha Mead; Alfred Preece Jr and Haami Piripi. Each has a specific understanding of repatriation and some of them have unique affiliations with Te Papa. For example, Hokimoana Te Rika Hekerangi was the former resident kaumātua during the exhibition Tuhoe: Children of the mist from November 2001 to November 2003. Thanks to the different experiences of its members, RAP represents a diversity of Māori and Moriori perspectives in terms of repatriation.

\subsection{The collaborative repatriation scheme in New Zealand}

The creation of the KARP programme was subject to numerous questions about how it would fulfil the objectives previously mentioned. It was important that tribal and government authorities worked together to offer this programme. To this end, the government of New Zealand established a six-point list that establishes the ethical limits of the programme.

- The government role is mainly one of facilitation - it does not claim ownership of kōiwi/koimi tangata

- Repatriation is by mutual agreement only 
- The programme does not cover the Māori or Moriori remains in war graves

- Kōiwi/koimi tangata must be identified as originating from New Zealand or the Chatham Islands

- Māori or Moriori are able to be involved in the repatriation of kōiwi/koimi tangata and to determine the final resting place

- No payment will be made for kōiwi/koimi tangata.

(Karanga Aotearoa Repatriation Programme, 2009b)

The government mandate shows a commitment to enabling the museum and the tribes to take part fully in this programme. The government presents itself here simply as a financial contributor. In addition, this transaction must not be the result of a commercial transaction and must be approved by both parties in the same terms. In 2007, the ceremony in Rouen was an example of such a misundertanding. The ceremony was held without the conditions being accepted by all those in authority. Because the deaccessioning of the heads of the French collections had not been respected, the government authorities refused to hand over the heads to the delegation who came from New Zealand for that express purpose. According to the founding terms of the programme, the ceremony could not end if there were still disagreements on the French side.

Throughout my experience in the repatriation team, the support of several museum professionals has allowed me to complete my research. This desire to work within museum teams to focus on the management of taonga made it possible not only to concretise the political will to share, but also to value Indigenous thoughts on the ways in which these treasures were cared for. Despite lingering tensions, Te Papa's staff want to continue to focus their attention on their research and the next collaborative projects they are working on. My stay at Te Papa allowed me to observe and testify to the importance of inviting interns or foreign researchers to participate in Māori activities. The various departments also interact daily to discuss the various problems encountered in certain aspects of the research. NSTP, researchers and curators work with the repatriation programme to assist in research or conservation of human remains. 
Some curators from other museums were also invited to lead a workshop on the methods of preservation inside the wāhi tapu. During my two internships, I could ask for the help of curators in terms of research and Māori knowledge or scientific advice. If I had a question on the relationships with tribal authorities and their heritage or about repatriation requirements, NSTP offered me help to further my understanding. During the "kaitiaki Māori hui" of 2009 Hema Temara, coordinator of the marae and tikanga at Te Papa, expressed the need for the Māori museum staff to be advised by the "pakeke", elderly people, that they "sit down with us and guide us" in order to effectively operate as kaitiaki which requires a "foundation, or tuarā (spine) provided by the elders" (McCarthy 2011, 106).

The intervention of elders in repatriation activities is key, as their great knowledge of mātauranga Māori and the valuable relationships they represent between iwi and museums create opportunities for the repatriation programme to collaborate with people experienced in tikanga. Moreover, at the time of my internship, the museum was also advised by Hema Temara. Even though she was looking after every event that took place on the marae, leading every pōwhiri and waiata practice, Hema was also part of several repatriation delegations. She took part in the delegations to England in 2009 and the United States in 2014.

In turn, we would like to thank all the institutions we visited in November 2009 , in particular for your willingness and openness to follow tikanga Māori (Māori customary practice) during the handover ceremonies. It has been a pleasure to work alongside each of your museums during the repatriation process. Thank you for your professional approach and kindness. (Hema Temara in Te Pānui o Karanga Aotearoa, February 2010, 1)

Like Hema Temara, several members of teams other than KARP participate in the practice of repatriation. The members of KARP seek the support of other services in terms of participation in the repatriation ceremony. Also, even if the human remains are Māori, this invitation is not essentially sent to Māori members of Te Papa. Hence, during the weekly waiata, te reo or music practice, every member of Te Papa is invited also. I remember that during the repatriation of 20 Toi moko from France in January 2012, I performed the haka pōwhiri alongside Arapata Hakiwai, Shane James and Shane Pasene (kaitiaki and leaders of the staff taonga puoro group who perform on the marae), Dougal Austin (Senior Curator Mātauranga Māori), Paora Tibble (Iwi Development Advisor) and Tom Ward, but also 
several Pākehā staff members including Leroy Holmes, Kim Gustavsson, Tanja SchubertMcArthur and Florence Liger who wanted to acknowledge the influence of the bicultural policy. This active support of the repatriation programme proved the efficiency of collaboration with different departments of the museum in the joint effort to return tūpuna to their final resting places.

To conclude, kaitiaki are required to know the procedures carried out on the marae. During the repatriation ceremonies on Te Papa's marae, they actively participate in the ceremonies. Therefore, I might see Hema Temara taking a leadership position or acting as kaikaranga to initiate every haka pōwhiri; or I would see researchers-curators such as Rhonda Paku, Hokimate Hardwood, Puawai Cairns and Awhina Tamarapa taking their places alongside Lisa Ward, kaitiaki and KARP researcher-archaeologist Amber Kiri Aranui in front of the wharenui. Every individual from Te Papa who wants to be part of such an event comprises 'tangata whenua' or hosts on the marae which, in this case, is the people of Te Papa. The tangata whenua is then ready to welcome the manuhiri (guests) and to cover the Toi moko and kōiwi tangata when they arrive with kākahu for the remainder of the ceremony.

\subsubsection{Hui à rohe}

It is clear that one of the aims of KARP is to raise awareness among international institutions of the effects generated by repatriation operations among Māori tribes. However, the diversity of tribes and their different interpretation of ancestor cults and funeral rites makes it difficult to promote one unique perspective on these operations. As Te Herekiekie Herewini put it in his interview:

Every time we meet a different iwi we had to be respectful of what they do.

Different iwi are doing things differently. And we have to be respectful of their customs, their tikanga, their kawa. (Herewini 2019, 13'min)

Different wānanga and hui ā rohe are organised by Te Papa and the research programme in order to discuss the sensitive issues of the strategic objectives of the repatriation operation. This is why, since 2010, KARP has organised meetings throughout the country with different groups. This long-term collaboration enables the research programme to collect the multiple accounts of the ancestors necessary for the advancement of its research, thus meeting the expectations of the various international institutions participating in returns. During these meetings, or assemblies, each person affiliated to the tribe is invited to attend and intervene on the points raised. 
And I think there is a sense of responsibilities to them (Iwi) because of the hui $\bar{a}$ rohe. But absolutely it is a major goal for our programme even if we start it up again. One of the goals was to find a final resting place options. (Coralie O'hara 2019, 31'min)

Usually held in the wharenui of the marae, these meetings take place according to the rules to be respected in these traditional houses: no shoes inside, no food, a karakia is recited by the members of the tangata whenua before entering the building, the Māori language is preferred to English during the speeches and a snack is commonly offered after these discussions in the whare kai.

During the hui à rohe, several topics are discussed: the role of tribal groups in the organisation of repatriations but also current issues such as the care of the deceased whose tribal affiliations could not be established, or the forensic analyses applied to these deceased. Since the implementation of this initiative by the museum, KARP, and the RAP, several meetings were held between 2010 and 2012 .

Table 3: Hui ā rohe organised by the KARP and their locations:

\begin{tabular}{|l|l|l|}
\hline Territory/Tribe & Localisation & Date \\
\hline Ngāi Tahu & $\begin{array}{l}\text { Te Rūnanga o Ngāi Tahu, } \\
\text { Head Office, Christchurch }\end{array}$ \\
\hline Tairāwhiti & Toihoukura - Tairāwhiti & Wednesday 14 April 2010. \\
& Polytechnic, Gisborne & \\
& Te Rūnanga o Ngāti Awa, & Tuesday 7 June 2011. \\
\hline Mataatua (Waiariki) & Whakatāne & \\
& Rātana Pā & Tuesday 13 August 2011. \\
\hline Te Taihauāuru & Waitetoko Marae & Vendredi 13 et samedi 14 \\
& & octobre 2012. \\
\hline Rātana Pā & & Monday 29 November \\
& Whakatū Marae, Nelson & 2012. \\
\hline Te Tau Ihu o te Waka & &
\end{tabular}




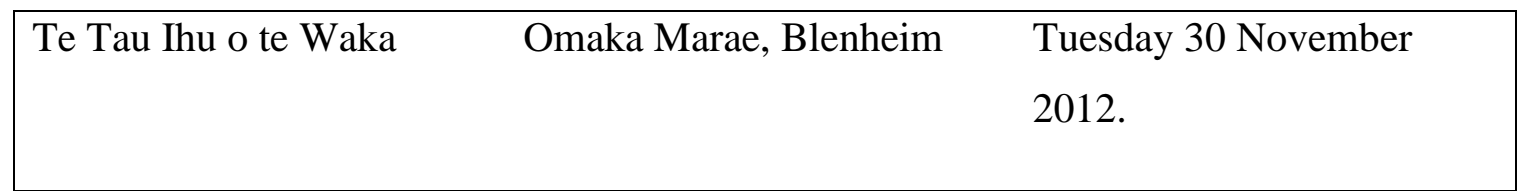

During these gatherings, researchers can be invited to contribute the results of their work with that presented by KARP and other Te Papa professionals. Those round-table discussions also provide an opportunity for the various speakers to present the progress of their research, and to update the results that concern each group visited.

At the hui à rohe that took place in 2012, the repatriation programme invited me as a speaker to present the stages of research undertaken on the donors of Toi moko in France and their conservation in the various infrastructures. In April 2012, Te Herekiekie Herewini explained that there were still many iwi to meet in order to finalise the main questioning of his team about the future of human remains without recognised provenance.

Further hui ā rohe will be held with Ngāti Tūwharetoa, Te Arawa, Tauranga iwi, Hauraki iwi, Tainui, Tāmaki makau rau iwi, Ngāti Kahungunu, Te Ūpoko o Te Ika / Ngāti Raukawa ki te Tonga, Te Tau ihu o te waka, Chatham Islands, Tai Tokerau iwi. (KARP 2012, 35)

\subsubsection{Hui ā rohe at Waitetoko Marae 12 October 2012}

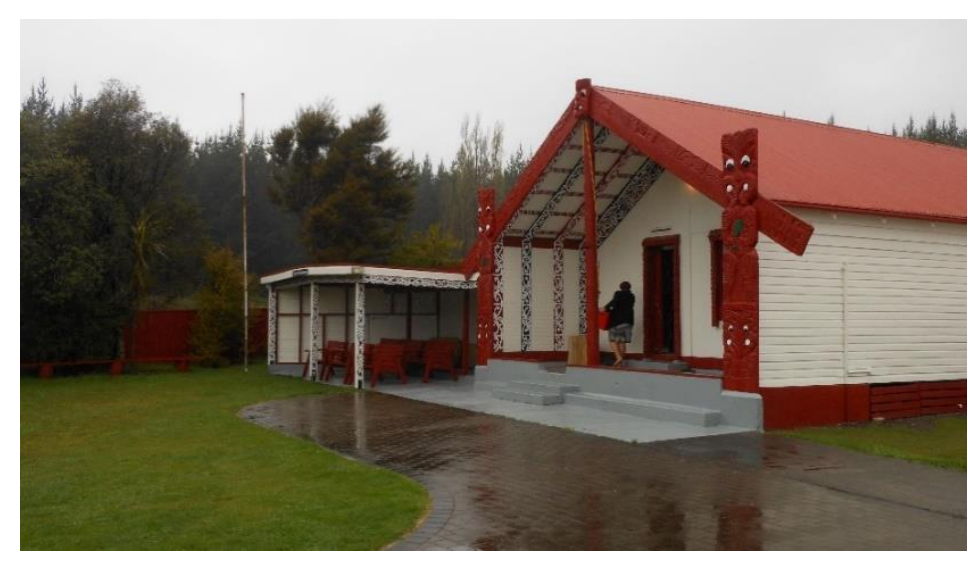

Figure 3 Waitetoko marae
My various trips alongside the researchers of the repatriation programme allowed me on several occasions to meet members of various tribes across the country. Thanks to the agreement with Te Herekiekie Herewini, my participation in each of the trips organised by the programme, for a

restitution ceremony or a hui à rohe, allowed me to increase my knowledge on the extent of negotiations between the research team and tribal groups. Thus, my research work in New Zealand was punctuated by conferences and seminars allowing me not only to present the reasons why the programme had invited me but also to publicise my research undertaken over the previous months. Allowing me time to speak during these meetings was certainly an 
opportunity to present my research but also to feel integrated into the team in view of the scientific value it attached to our collaboration. Prior to the meetings, Te Herekiekie Herewini presented the speakers with a schedule of the presentations: each speaker was allocated 15 to 20 minutes for presentation and 10 minutes for questions from the audience.

The first hui à rohe was held on the shores of Lake Taupō in the Te Waitetoko marae of the hapū Te Rangiita of the Ngāti Tūwharetoa tribe. After having returned five human remains in April 2012, the origins of which had been found and affiliated with several hapū in the territory of Taupō-nui-a-Tia (the Taupō region), the Te Papa delegation was invited to return in order to give an account of their work. In addition, there were genealogical links between the programme and this tribe because all speakers were affiliated with Ngāti Tūwharetoa. This created a desire on their part to exhibit their research with great enthusiasm and emotion.

On the evening of Friday, 12 October, 2012, the Te Papa delegation was greeted at the Te Waitetoko marae by the hapū and kaumātua of the tribe. On this occasion, karanga, whaikōrero, waiata and harirū (hongi and hand shaking) were exchanged to welcome the new arrivals. The invited team was led by kaumatua Te Kanawa Pitiroi and Whaea Hokimoana Te Rika-Heterangi. Following him were permanent members of the programme, Te Herekiekie

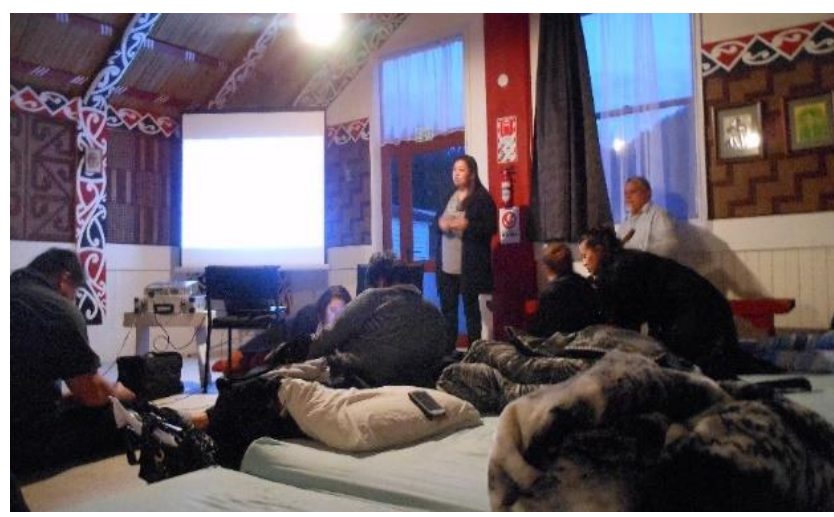

Figure 4 Rhonda Paku during her kōrero.
Herewini, Amber Aranui and Mona Pauline Mangakahia (coordinator), the curator of the Mātauranga Māori team from Te Papa, Rhonda Paku, an iwi relationship development officer from NSTP, Gavin Reedy and myself. A kaitiaki of the Whanganui Regional Museum was also among us, Awhina Twomey. After sharing dinner prepared in the whare kai, Te Herekiekie Herewini, Rhonda Paku and Awhina Twomey made several presentations on the taonga and kōiwi tangata kept in museums, in particular emphasising their likely connection to the hapū of Te Rangiita.

Through this initial approach, the intentions of both parties were clearly manifested. On the side of the speakers, questions persisted as to the history of the taonga to which the interested group could potentially respond, and on the other, it was a question of ascertaining how they were stored and managed in the museums of Wellington and Whanganui. These presentations 
thus specified the role of each party in the conservation of the Māori collections according to both the tikanga and the bicultural ambitions of the two public establishments.

The next day, the seminar started around 9:30 am inside the same wharenui. We started the day with the presentation led by Amber Aranui on the repatriation of human remains in April of the same year and on the trade in Toi moko on the island of Kāpiti where some of these heads affiliated with the Ngāti Tuwharetoa tribe were traded with Europeans. This

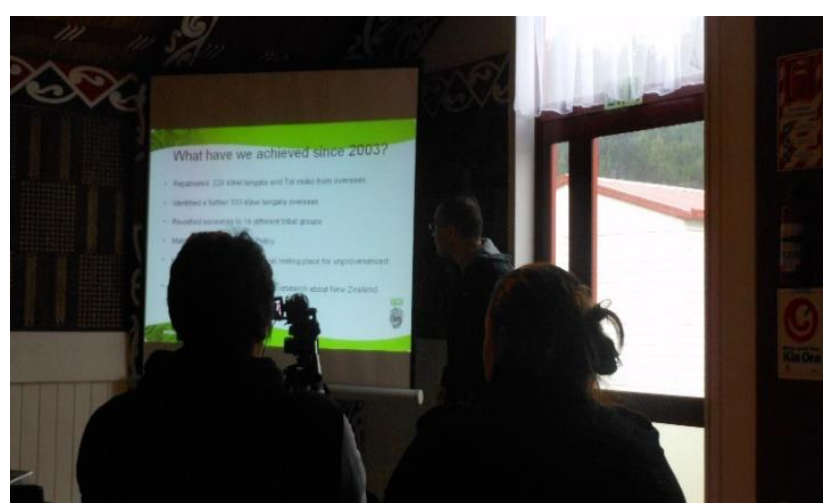

Figure 5 Te Herekiekie Herewini developing the KARP principles. presentation aroused great interest among the members of the hapu Rangiita and the tribe in general, by testifying to the difficulty of the research and the steps necessary to arrive at convincing results on the whakapapa of the deceased. The kōiwi tangata returned to the Ngāti Tūwharetoa tribe had been kept in the Dominion Museum and then the National Museum before the construction of Te Papa where they remained while this research was carried out. Between 1918 and 1984, numerous burial sites and graves were visited by pillagers and collectors, in still obscure circumstances, in the Taupō region in order to put the kōiwi tangata into the museum and keep them in better conditions according to western beliefs.

My presentation was focussing on the research undertaken on human remains formerly preserved in France and the nature of the facilities where they were preserved. The purpose of my presentation was to illustrate the complexity of the debates to which Māoriheads were subjected in France and the difficulties encountered, in certain cases, to find their origins or the routes taken since their departure from New Zealand. My presentation of the archival material and other documents used to find the exact identity of the donor of the head kept in the Museum of Rouen and the development of a hypothesis about its transportation to France aroused the curiosity of the public and several questions were addressed to me at the end of this speech. My use of a Māori vocabulary to present the sacred dimension of these Toi moko was positively received by the audience. The curiosity of the iwi was expressed by various questions about my personal motivations behind the research in New Zealand.

Te Herekiekie Herewini's speech began with a description of the trade between Europeans and tribes during the 'Musket War'. It then discussed the ethics of the strategy chosen by the 
programme concerning human remains whose origins could not be traced. He explained the various proposals made concerning where these remains could rest. The Ngāti Kurī tribe had proposed in 2006 the creation of a cemetery near Te Rerenga-wairua (Cape Reinga) within their territory, or the creation of a mausoleum in a strategic location in view of the tribes. The creation of several cemeteries had also been suggested in order to share the role of guardian under the authority of several tribes. The creation of another cemetery on the East Coast where a large majority of the Māori community is represented was also mentioned.

During this exchange, we were able to observe the audience's concern to preserve the traditions and beliefs of each tribe about the resting places of the deceased. Although there is a generally accepted belief about the journey of the spirit of the deceased to the underground kingdom and its entry through the gate of Te Rerenga-wairua, many tribes believe in the existence of other gates which enable the wairua to join this same domain. The hypothesis of a single mausoleum received measured responses from the audience. The discussion in the hui is captured in the following notes

Te Herekiekie opened the discussion up to the hui and the following comments were received:

- It is important to recognise the significance of the Ngāti Kurī tono which was tabled at the National Repatriation hui at Ngāti Tunohopu marae in Rotorua in 2006;

- It is important that further research is undertaken with the Toi moko and that they remain at Te Papa so this research can take place; and

- Further research into the moko patterns on the Toi moko is important, as this could help to identify individual tohunga ta moko who performed these activities, and also may help to identity provenance.

In response Te Herekiekie confirmed that Te Papa wishes to undertake research on the moko styles and patterns to help in the process of identifying provenance, however, Te Herekiekie added this research was only in its early stages. (KARP 2012a, 7)

These seminars provide an opportunity for the programme to identify the wishes of the iwi and hapū regarding the future of research, their involvement and the procedures to be 
followed in future repatriation procedures. The future of human remains without recognised identity affiliations remains without a definitive answer.

\subsection{Kaihurahura Whakahoki Kōiwi Tūpuna o Aotearoa}

The interaction between teams at Te Papa working on Māori activities such as repatriation has also been observed between repatriation practitioners located in different museums. I would argue that, thanks to the increasing influence of the Indigenous community in New Zealand museums, museum professionals are trying to create expansive relationships through and under the mission of repatriation. The New Zealand Repatriation Research Network (Kaihurahura Whakahoki Kōiwi Tūpuna o Aotearoa) is a new chapter in museum practice in New Zealand. Instead of dealing with repatriation on their own, some of the most important museums in the country, in terms of collections or administration, are discussing repatriation issues. I had the chance to witness the global effect of this Network during the Museums Aotearoa Conference in May 2019 at Te Papa in Wellington. One workshop focused on repatriation and members of several museums gathered in order to put together a national repatriation policy. The repatriation team at Te Papa is maybe the most important programme in the country, but it can't work independently. In February 2020, 17 members from different museums created a national network dedicated to the repatriation of human remains (Aranui 2020). Auckland War Memorial Museum also has a repatriation team. Its leader, Coralie O'Hara, describes the objective of this repatriation network in these terms.

The three of us [Amber Aranui from Te Papa, Awhina Twomey from Whanganui Regional Museum and Coralie O'Hara from Auckland] have been sharing information, helping each other for a long time. And last year, there was one in Australia that she's been involved with. Through Museums Aotearoa we formed the Repatriation network. So that's put more formality around how we were already keen to share information with each other.

Since then, there's more of us sharing information about where repatriations are, who you are working with and more provenance information. Since we formed it, we shared a lot of information. (Coralie O'Hara 2019, 15'min)

The role of each professional in museums, whose task is research on Māori and Moriori human remains, is primarily to look after human remains, take good care of them, and ultimately return them to their land of origin. As Coralie O'Hara explained in the quote above, by sharing information, repatriation can also be more effective in terms of research into the 
origins of each ancestor. Auckland War Memorial Museum, Te Papa and Whanganui Regional Museum place a lot of importance on this type of research, and Canterbury Museum, Nelson Provincial Museum are also following this initiative by sharing information during the meetings of this network.

\section{Conclusion}

This chapter has shown that in New Zealand, the process of repatriation of human remains has been part of the museum environment for several decades. The concept of kaitiakitanga reflects another perspective on the museum's collection which challenges the Western idea of material property and related ontological principles that have underpinned museums since their birth. In sum, KARP does not 'own' Toi moko returned from overseas but merely looks after them until their final resting place is found. Its close relationships with iwi on every matter related to the process of repatriation is a key factor in understanding the policy applied in this programme. The influence of tikanga is then felt in every step of the process in terms of Toi moko, from the provenance research right up to the domestic repatriation itself.

As part of such a policy, Indigenous culture and knowledge is increasingly seen and heard in museums. From the Te Mãori exhibition in the 1980s to the creation of KARP in 2003, Māori are clearly better represented in terms of professional staff in the museum field. But museums in New Zealand do not always work closely with local Māori authorities and the national museum had to present a path to follow, a model that others could follow. As I have demonstrated in my close analysis in this chapter of professional practice at Te Papa, biculturalism is not a model that can be applied in all situations, as most museums in New Zealand do not have the logistics or financial capacities to do the same.

However, Te Papa is not the only successful model in terms of the politics of Indigenous recognition (Butts 2002, 2003, 2006). I consider the Te Papa policy as a pathway, providing guidance in terms of Māori collaborative projects such as iwi exhibitions, iwi relationships through the programmes developed by NSTP and of course the work of KARP. Actions led by KARP and NSTP, like hui ā rohe, have helped foreign museums to understand the continuous relationship between ancestral remains and contemporary iwi and their local authorities. For KARP, the main attitude towards kōiwi tangata is not to keep them permanently at Te Papa but to find their final resting places. According to my analysis therefore, it seems the actual priority of KARP is to return kōiwi tangata from overseas, but human remains may stay quite a while inside the wāhi tapu. In this process, the fact there is a 
national museum where there is a programme dedicated to repatriation of human remains appears decisive in convincing foreign authorities, and in this case French authorities, to go ahead and complete these kinds of returns.

Having analysed the New Zealand side of the equation, I now turn to look at the French side. The next chapter will examine the quite different perspective of these exchanges from France, and attempt to see how French museums responded to and progressed through the negotiations by taking into consideration the perspectives of Māori representatives and New Zealand museum professionals. 


\section{Chapter Four}

\section{Museums in France:}

\section{"Museums as a place of debate"?}

\section{Introduction: Early experience in repatriation}

"Museums as a place of debate" (Minchin 2019, 65'min). This phrase appeared to be the leitmotiv of the Museum of Rouen when Sebastien Minchin and Catherine Morin Desailly decided to deal with the Toi moko as part of a repatriation process. The statement about museums and debate by Minchin from his interview quoted above represents the idea that repatriation can also characterise a new approach to international relationships between museums and implies an emerging practice within French institutions which are engaging with communities and particularly Indigenous people.

In the last chapter, I studied the repatriation policy and its application in New Zealand museums. More specifically, I wanted to explain how KARP is connected with the bicultural policy and practice at Te Papa. The interrelationships between the advisory panel, repatriation researchers and iwi are at the centre of this operation mandated by the government. This analysis helped us to get a better understanding of the role played by KARP within the political and cultural environment of the New Zealand museum sector largely due to its close engagement with several Māori representatives and authorities.

This chapter now examines the French response to the repatriation process. The first two sections of the chapter focus on the outcomes of the repatriation for French museums; I show how the process of returning remains is a form of reconciliation with the colonial past but also reflects political and cultural dimensions. Then I describe and critically examine the different ceremonies that occurred in France and New Zealand not only for the return of Toi moko but also for the return of the poupou Titokowaru. I show how those ceremonies had some impact on those involved and generated some uncertainties about one fundamental principle of the French Republic, the notion of secularism applied to public spaces. Finally, I use a quote from Jean Marie Djibaou that described exhibitions as a reference to life to emphasise what the 
repatriation of Toi moko has led to in terms of collaborative projects in French museums since the first ceremony in 2011.

The theme of museums as a place of debate which emerges from the research in this chapter echoes Clifford's theory of museums as "contact zone" (Clifford 1997). A museum is a central place where we can interact and understand different populations represented by the objects exhibited in the museum or at least stored in the collections, including human remains. In this chapter I ask: What has been the impact of the repatriation operation on the relationships between Māori communities and French museums? From the initial negotiations to the post-repatriation projects, what have been the outcomes of repatriation in French museums? This chapter presents research exploring what happened on the French side of these exchanges, with the repatriation of Toi moko being the first time that French museums in general worked alongside Māori researchers and museums professionals. This created new forms of collaboration and ways of working and a space to practice what seemed to be just a theory up to then. This interaction between French and Māori through the repatriation process, from correspondence and dialogue to events and information exchange, therefore embodied a new understanding of the past which encompassed different perspectives of the common history of France and New Zealand.

The chapter also shows how emerging relationships between French and New Zealand representatives were shaped by different experiences of museums and different understandings of the social role they can play. I describe and analyse various ceremonies and events in which both sides interacted and created new types of cultural programmes where both perspectives intermingled. Ceremonies, which I describe in detail below, were the final interactions between French and Māori which raised questions and issues for both sides in terms of mutual understanding. This collaborative approach helped to create what researchers have referred to as "decolonising museology" (Bergeron and Rivet 2021). Museums are now seen as the place to confront different ideas in the same debate. In Rouen for example, the exhibition of human skeletons in front of primates' skeletons was a way to answer the primary issue in which museums have been engaged since the $19^{\text {th }}$ century; namely the debate between Creationism and Evolutionism. In the case of repatriation, this operation also had some effects on museum ideology, confronting and challenging the universalism and secularism of French museums with the biculturalism at Te Papa, as I show in later sections of this chapter. 


\subsection{The practice of reconciliation with the colonial past}

France has built a solid world-wide reputation for the past two centuries for the quality and importance of its museums. With some famous sites such as Chateau de Versailles and the Musée du Louvres, France figures prominently among the countries reputed for their historical monuments and museums. In fact, France is the country that hosts most visitors to its public institutions. In 2018, the Musée du Louvre became the first museum ever to host more than 10 million visitors per annum. Despite this surprising statistic, there are still several assumptions concerning the exact numbers of museums in the country, which may be between 3,000 and 10,000 if every exposition sites is also included in these statistics (Labourdette 2015, 3). Thanks to the "Museum law" passed in January 2002 and the creation of a new category of museums, 1,218 institutions located all around the country have attained the status 'Musée de France'. All of the museums that repatriated Toi moko in 2011 and 2012 had this title. According to the law, every institution with a permanent collection which is conserved and displayed in the public interest and organised with a view to providing the public with knowledge, education and enjoyment can apply for this appellation (Heritage Code, Article L.410-1).

A high commission has been implemented to award the title to new museums and to administer contemporary networks among museums in France. Consequently, this title helped institutions gain financial support from the Ministry of Culture even if some of these museums were administered by local authorities. The Musée de France framework is concerned also with the management of collections. Every museum uses the same database in order to achieve an inventory of the collections and thereby facilitate better inter-institutional communication. This title is not allocated to only one category of museum. As illustrated by the museums that have returned Māori ancestral remains, all kinds of museums can apply for this status. None of those museums, labelled 'Musée de France', focus on the history of the French colonial empire. There are institutions that work on affiliated topics, such as the Musée de l'Immigration in Paris and the creation of temporary exhibitions like Human Zoo: The Invention of the Savage at MQB-JC in 2011 but there are no institutions entirely dedicated to France's colonial past. According to Pascal Blanchard, a project of "Musée de la colonisation" should have been created in 2015, but unfortunately, this museum will never be inaugurated because of fears from the government and the unpredictable reaction of the public 
(Blanchard, 2018, 5'min). ${ }^{12}$ This cautious view reflects the tendentious and partial perspective in the education system towards the French colonial past.

This tendency is also reflected inside the French museum environment. Museums, and not only ethnographic museums, face difficulties with the conservation and presentation of foreign collections derived from their colonial heritage. As soon as the Museum of Rouen contacted Te Papa, analogies were made between this long-term problem of the colonial legacy and debates around Māori human remains within museums.

We can also imagine the loans of objects in museums. Here lies again the question of property. We can imagine a circulation when the conditions are good and intensify the transfer of the pieces of art, or exhibitions, that are going to some place and back. I believe that new forms of international cooperation exist today, with new means of transport, which allows us primarily to write history with lucidity. Because it needs to be told and not just any which way. (Morin Desailly 2019, 25'min)

Duty of remembrance is a central commitment made by public institutions in France. By possessing the desire to transmit knowledge to future generations, museums embody the role of a tool in the service of democratic issues. Since WWII, museums all around the world have progressively become used to raising questions related to issues such as decolonisation, equity and identity (Bergeron and Rivet 2021). In France, however, museums did not know how to manage collections considered to be ethnographic other than by traditionally Euro-centric approaches. Furthermore, in natural history museums, for example, the type of museum where most of the ethnographic collections are preserved, professionals did not have a specific anthropological background.. This is highlighted in one of the interviews:

None of them [directors of Natural History Museums in France] had any training in Anthropology before, however it is in these museums that there is the richest so-called exotic collections. So they were all confronted with this situation and they were happy to have people who helped them with the inventories. (Boulay 2019, 16’min)

\footnotetext{
12 Pascal Blanchard, « Pourquoi la France est incapable d'avoir un Musée de la colonisation ? », Youtube video,
} 25 :23, Théâtre du Rond-Point, 24 january 2018. 
This behaviour generated a complex situation among museum professionals that demonstrated the ambiguous position of such collections, even more so when mainly human remains composed the collection in question. Because these collections were controversial and were rapidly defined as 'sensitive' according to ICOM, museums chose to put these collections away in storage, where no debates could be held, or solutions could be discussed. Museums were, thus, sustaining a certain imbalance of power, the unilateral colonial attitudes that led to their creation in the $19^{\text {th }}$ century. Human remains were, thus, considered to be hidden, and sometimes were forgotten. Museum practice was still shaped by the 'old museology', the ethnocentric display of foreign communities during universal exhibitions and the human zoos organised up to the middle of the $20^{\text {th }}$ century.

In 2018, the Observation Cooperation Informations Muséales (OCIM) published a vade mecum on human remains in French public collections. According to this research led by Michel Van Praët, nearly 150,000 human remains are located in French public museums or universities (OCIM 2018, 3). The manner required within French public institutions to look after human remains includes consideration of ethical and spiritual values of the community of origin. That is why, in France, two major principles are delineating the legislation towards this high-profile type of collection, one is the principle of dignity and the other is the philosophical principle that prohibits the selling or purchase of any human remains.

The respect due to the human body does not end with death. The remains of the deceased, including the ashes of those whose bodies have been cremated, must be treated with respect, dignity and decency. (Civil Code, Article 16-1-1)

Inspired by the Age of Enlightenment in the $18^{\text {th }}$ century and policies that led to the abolition of slavery in the $19^{\text {th }}$ century, this philosophical principle still frames the French global perspective today. This principle means that most of the human remains located in French public institutions are donations and are inseparable from their context of acquisition. The principle of dignity is reflected in how collections are documented and preserved. However this noble aim is not always followed up in practice especially when human remains are located in different museums. The Musée des Arts Décoratifs in Paris contacted the staff of the MNHN, including Michel Van Praët, in order to discuss two heads they 'discovered' in boxes. They did not want to keep them anymore because it clashed with the modern museology now in place in this museum. They wanted to send them to the MNHN where, they assumed, human remains would be better preserved. They did not have any 
information filed concerning these two heads. The heads might be Egyptian with rubies in place of eyes. Previous curators had used them as lampshades to spread the light in a gallery of the museum before putting them away and consequently losing them in those boxes (Van Praët, 40'min). This lack of appreciation concerning human remains and foreign collections is noticeable not only in Paris but in every city of the country. This critical analysis is not intended to cast wholesale blame on French museum professionals but to inspire transparency with regard to the results of bad judgements of the past which were prompted by Western imperialism and to aid the contemporary conservation of human remains. As one French scholar put it:

The best we can wish for the musée du quai Branly is to be neither a museum of Others, nor a museum of oneself, but to become a museum of relationship-making between us and others, that incorporate reflectivity as condition of access with another. (de l'Estoile 2007b, 13)

The Toi moko case study contributes to this broad discussion regarding the colonial past. The repatriation process helped the French museum professionals to gain more information about their collections. The use of museums for such operations as repatriation appeared to be a process of restorative justice, reconciliation and healing, according to Hakiwai. Such issues are an "important contemporary reality for many Māori as they embark on the journey to address historic grievances through the Waitangi Tribunal" (Hakiwai 2014, 6). French museums can also get the support they need to learn more about past events such as the Musket Wars and French attempts to settle in New Zealand. Therefore the repatriation process can help people to understand colonisation in its broader sense by analysing one particular case, like the Musket Wars, and interpreting it through Indigenous perspectives that also reflect Western imperialism in New Zealand and how France played a role in it.

The repatriation process enables museums to engage in reconciling this relationship of coloniser-colonised by opening up debate about the moral responsibilities of museums with human remains acquired from foreign territories. This in turns opens up French museum practice to other contemporary approaches such as the exhibition of artefacts from other cultures which, moreover, at present do not accord any input from those whose culture is being represented. Patin calls this a "new moral space" in museums:

It appears that the evolution of moral values demonstrate that Human is not an object completely delimited but an entire field of possibilities whose 
borders are evolving in space and time. The museological taboos from the past have been replaced by new moral space (Patin 2010,11)

Because repatriation is deeply engaged in this "moral" approach of the new museology, this process of return also means such institutions are politically engaged in their local territories. In France, as in New Zealand, repatriation is a result of moral engagement with a 'sensitive' collection, according to ICOM, and places importance on the notion of Indigeneity in "its actual onusian acception" (Gagné, Martin, Salaün 2009, 16). By questioning the Western monopoly concerning collections from outside Europe, repatriation represents a post-colonial approach towards such collections.

Another aspect of repatriation reflects this new balance of power in a post-colonial context in France. This time the operation engaged a French museum with a former colony still under French authority. The government decided to return the heads of two Kanaks from New Caledonia. France returned the head of the chief named Ataï and the head of his sorcerer Andja. In 2014, the MNHN returned, by administrative means, those two heads of activists who fought against French imperialism in New Caledonia (Patin 2013). This act was an important apologetic gesture aimed at restoring better relationships between Indigenous groups and France. In this case, political arguments are ubiquitous but also shaped and were in turn inspired by a promise of the return of cultural objects which dated from 5 may 1988 during the "Matignon agreements" (Article 1.3.2). During those agreements, French and New Caledonian authorities agreed to progressively extend the power of self-determination to the former colony (Roustan 2016, 157).

\subsection{Political/cultural and scientific operations}

The interrelation between political, cultural and scientific spheres is undeniable when it comes to repatriation. Because of a legal paradox, the French authorities chose to clarify the debate by inserting an important political and legal dimension in the process. This choice led professionals (other than museum professionals) to try and sort out the French position concerning the specific question of Māori heads. These connections not only give clues as to the type of relationships this operation created but also emphasize the complex position of French authorities on Indigenous human remains in French museums. The three spheres (political, cultural and scientific) can share some common purposes but do not have the same approaches and same practices to achieve their goals. As soon as the political sphere intervened in the negotiations, the purpose of this operation did not lie primarily in the 
museum collaboration but took on a dimension of diplomacy and reconciliation. The use of concepts such as ethics or moral values stated the position of French politicians towards this programme that could appear apologetic and focused on past actions. To them, repatriation was a chance to show compassion and equity towards a community unknown until then and could be considered an attempt to fulfil modern Western moral values of equality and equity in the treatment of ancestral remains (Patin 2011, 13). Although museums understood more about their collections, the primary approach of politicians remained focused on the past and the imbalance of power experienced during the colonisation period. Here lies one of the dissensions concerning the main effects of repatriation. Are French apologising for their involvement in the trade or are they focusing on further cultural collaboration perhaps expected by museums professionals? This question is also related to the diplomatic outcomes of such international collaborations. At the beginning of the negotiations, the Museum of Rouen, or any other French museum, had to gain the support of their governing authority. The approval of the city hall of Rouen is one example. In his interview Minchin explained it like this:

At one point if a politician doubts the approach, it's over... This restitution process spanned several mandates of different mayors. This could also have impacted political influence in the management of the debate. And its media coverage. All the municipal teams with which I have worked have always supported this approach and it is something that I must highlight. They were always on the front line, taking the blows, protecting me because I was pressured by the DRAC ${ }^{13}$ but also from the national museums which sent me letters of threats and insults. Letters, phone calls, threatening me. Saying you're done, your career is over... It was a complicated time. (Minchin 2019, 9'min)

In this tense situation, the interrelation between curator, director of museums and cultural affairs representatives was necessary to complete the repatriation successfully but looked very difficult to implement. In France, museums cannot operate independently and are caught up in a complex multi-layered cultural administration. This situation may also engender tensions with representatives of external sectors such as political or academic sectors but also among museums themselves. That is why the prospect of repatriation as a museum practice was and

\footnotetext{
${ }^{13}$ Direction Régionale des Affaires Culturelles (Regional Direction of Cultural Affairs).
} 
still is widely debated in the museum sector. This was seen when Catherine Morin Desailly, as a senator, decided to create a support committee headed by Pascal Picq, paleoanthropologist and professor at the College de France. The nature of this committee reflected the range of jurisdictions concerned with the debate and also the political repercussions of such a decision. The politics involved with the return of Indigenous ancestral remains was clear in the interview with the Senator:

They took a position in favour of the repatriation. So in this case suddenly it becomes a controversy and it is talked about all over the world. All over the world there is press on the subject, and thus a support committee is formed [...] Because we had explained well, the idea was not to empty the museums, it was to think very particularly about the status of some human remains, it was not all human remains... (Morin Desailly, 28'min)

Composed of researchers and politicians and also well-known French writers such as Didier Daeninckx and Philippe Delerme, the committee was able to promote repatriation as an ethical act. It also proved that key scientists, politicians and writers shared the same moral approach. This political process might appear to be only one piece of the puzzle but it was necessary at the national scale so as to create a consensus and then led to a proposed law in favour of repatriation. If repatriation became legal, then all museums, national or local would be disposed to follow it. Museums are public institutions, and the state of France morally owns the collections. Hence curators are responsible but are not the owners according to the Code of Heritage. Michel Giraud, head of collection at the MNHN, said that "Scientists are not entirely concerned about the repatriation, it is really about a political gesture from a nation to another." "We are only concerned because we are the custodians of the collections," he continued, "[b]ut don't ask us to answer a question that is not scientific" (Guiraud in conference at MNHN, 2012, $\left.15^{\prime} \mathrm{min}\right) .{ }^{14}$

The repatriation operation was carried out by curators and scientists but also led by politicians. For many curators, repatriation should be entirely conducted by museum professionals. Because the debates created conflicts within each of the fields mentioned

\footnotetext{
${ }^{14}$ La question de la restitution des restes humains (Restitution des têtes maories / tout public 2/3), Michel Guiraud, conférence at MNHN 21 January 2012, Online video, Youtube, posted on 26 July 2016 (accessed 22 May 2020).
} 
before, cultural, political and scientific, museums could not make any decisions by themselves. They were always restricted even if their collections were at the centre of the discussion. Michel Van Praët told me that: "The principle of the ICOM code of ethics tells us that if we can avoid the political framework, we already avoid many problems, if we base ourselves on a professional basis" (Van Praët 2019, 21'min).

The repatriation of Saartje Baartman to South Africa in May 2002 was largely considered a precedent for the debate on Toi moko by the media and repeated by museum practitioners and politicians. But there is another return that occurred only few months later and concerned only the professionals of the MNHN, namely the return to Uruguay of the skeleton of the chief Vaimaca Peru which occurred in July 2002 without any political or legal involvement. The decision had been made by administrative and non-legislative means (Cornu 2009, Van Praët 2013). Back in 2008, a special meeting was scheduled to talk about the Toi moko at the Musées de France council. The Museum of Rouen and the other museums concerned with repatriation so far (only 5 Toi moko were known at this time according to Sebastien Minchin 2019, 12'min) had the status of Musée de France, so the council had to discuss the outcomes of such an operation for these public institutions, before entering in to dialogue with politicians. After a discussion, the museums representatives who attended this meeting voted in favour of the repatriation. Unfortunately, the previous restriction towards the return of the Toi moko at Rouen involved the Ministry of Culture and later jurists from the Tribunal of Douai and, at some point, museum activities were over-ruled by authorities such as local councils (city, metropolitan or regional councils) or the Ministry of Culture concerning the MQB-JC.

Due to this political control and interference, this collaboration was not achieved. Because this process took nearly six years, political representatives such as ministers, mayors, senators and even ambassadors in charge succeeded one another. These changes made durable relationships between museums and politicians more difficult to establish and maintain. The minister of culture who was against the repatriation in 2007 was replaced in 2010 by Frederic Mitterrand. The new minister took this case as an opportunity to endorse his new position and was also the first project he led in front of the Senate. Choosing this case was not a random choice. For Mitterrand, repatriation was a post-colonial museum practice (Mitterrand 2012). Today, repatriation is the result of a global diplomatic evolution that also impacts museum practices worldwide by re-considering its role in contemporary society. However, no museum is the same, the variety of missions, the public and the scale they are working at all determine 
how these precepts are put into practice. With the Toi moko repatriation, repatriation practitioners or observers could attest to the imbalance of power, politically or administratively, between Parisian museums and territorial museums. In fact, the new MQBJC was facing new challenges and showed an interest in dealing with international projects by itself. Despite the fact that the museum was initially against the repatriation, the staff took the opportunity to create a sustainable relationship with Te Papa. This new museum brought together the ethnographic collection of two other museums: Mankind Museum and MAAO. By creating a specific museum for this kind of collection, French cultural authorities wanted to create a new museology and draw attention to collections from Indigenous communities. Reflected in the change of its own name (by adding the name of Jacques Chirac to commemorate the president of the French Republic who decided to create such a place), the MQB-JC is clearly regarded as a political gesture and has a higher media profile than local museums (de l'Estoile 2007b, 1).

Although the MQB-JC represents an up to date tendency in the museology of 'primary arts' collections in France, it is not the only change occurring throughout the country. There are more and more directors of museums, and especially natural history museums, who have an anthropological background and do not come from the traditions of natural sciences. Boulay discussed this point in his interview;

In the early 2000's] There was the Quai Branly project, everyone knew there was a problem at the Musée de l'Homme, there were also museums in France such as Angoulême, Nantes, La Rochelle which were starting to take into account professionally and importantly all these collections, making room for them between giraffes and Herbarium. And La Rochelle is a whole story, the nominationas the head of a museum of an anthropologist is the revolution of the century!!! (Boulay, 21'min) [...] The Quai Branly has clearly the resources that other museums don't have, and it is getting worse. (Boulay, 35'min)

The first analysis of the context of repatriation negotiations showed an imbalance between local natural history museums, like Rouen and Nantes for example, who did not dedicate all their efforts to the ethnographic collections, compared to the MQB-JC which has logistical and financial support from the Ministry of Culture. Despite the political centralisation in Paris, the repatriation experience demonstrated the richness of collections throughout the 
entire country and not only inside the museums of Paris. Despite the status of Musée de France allocated to diverse institutions, museums located outside Paris are not on the same financial standing as the MNHN or MQB-JC. This situation may have initially convinced the Museum of Rouen to collaborate with other museums such as the Musée des Confluences in Lyon (Minchin, 15'min). Unfortunately, the repatriation did not happen at the same time but the repatriation debate did create diverse connections and collaboration among directors of different museums.

The organisation of two different conferences at MQB-JC in February 2008 and at the MNHN in January 2012 also demonstrated the Parisian monopoly in terms of French museum practice. The organisation of such an important event in a different city could have been challenging in terms of the balance of power between cultural, scientific and political spheres. That being said, those two events played a key role in terms of meetings, mutual understanding and cultural diplomacy. French repatriation practitioners all agree that the International Symposium held at MQB-JC in February 2008 provided the first opportunity not only to meet New Zealanders but also to take into consideration the legal paradox in which Toi moko were caught up at at this stage. For example, this symposium was the occasion for Sebastien Minchin to finally meet Seddon Bennington (CEO of Te Papa) and other New Zealand representatives who had been invited to introduce the New Zealand perspective on the return of Toi moko (Sebastien Minchin 20'min, Arapata Hakiwai 12'min).

Those two conferences were also an occasion to assimilate what would be involved for French museums to be part of such repatriation projects and, maybe, to change the minds of French curators and directors who appeared indecisive at this stage. Christine Albanel, Minister of Culture at this time and Senator Catherine Morin Desailly are the two politicians who were invited to speak during the symposium (Morin Desailly, 12'min). Despite the fact that Christine Albanel was against the repatriation, the ministry saw the opportunity here to present all arguments in favour and against the participation of French museums in the process. French, European and American museum professionals were present at this event as well as jurists and law specialists, anthropologists and scientists who could interact and talk about the growing Western international consensus towards repatriation. This symposium provided an opportunity for the Ministry of Culture and directors of museums to foresee the place allocated to France in this global scheme. By holding such debates, the symposium reflected not only the tension within French museums but also the complexity of the process inside French administration. "During the colloquium at the quai Branly," recalled Van Praët, 
"I was talking to the jurists of the tribunal of Douai and they told me that no one had told them [about the status of donations of human remains]. It means that my notes were not passed on.” (Van Praët, 15'min)

The symposium was also the occasion for staff from two important international museums Te Papa and the MQB-JC to meet. After the repatriation in 2013, both institutions would sign a memorandum of understanding to formalise and strengthen the co-operation between the two museums. This is an example of how repatriation changed the attitude about human remains in French collections. Despite their low numbers, France is still facing more repatriation requests, and every case is unique. As Michel Van Praët explained during his interview, it is essential to analyse and answer each repatriation request in order to create an exchange:

I think there should be a procedural law. Knowing that each case will be special. By saying Yes, human remains are not like any other collection. Their respect is decreed by the French constitution, but this respect is linked to the principle of respect for one another, for each individual. Each case is different, we have to accept the exchange, accept the repatriation in certain cases and the principle of dignity and see if we can determine its origin. And to be empowered to put conditions on repatriation because it is precisely believed that its dignity must continue. (Van Praët, 92'min)

As explained by the former director of ICOM France and head of the mission on human remains in French collections, the national policy on repatriation should not focus on every case but provide more tools to complete the process. Because every case is different, French authorities should base their approach on one procedural law. In accepting this recommendation, French authorities are proving their commitment to not only a new approach to the role of museums at an international level but also acknowledging the role of communities in the preservation of collections, including human remains, in French museums.

\section{3 “Repatriation ceremonies are unique experiences” (Desailly, 42' min)}

For foreigners, repatriation ceremonies can be a moving living experiences which testifies to the richness of Māori culture. Because repatriation is an involved and contemporary process, the ensuing ceremony conveys the cultural richness of Indigenous people and shows how their heritage has adapted to modern issues and is reconciling the colonial past. This impression on French observors can be seen in Gagné's interview, who commented on "The comparison 
between the 'traditional' ritual structure and the one from the repatriation ceremony is interesting to many respects, both symbolically and politically" (Gagné 2012,8).

In this section my analysis of the different repatriation ceremonies that took place in France show how they got across to French participants the contemporaneity of Māori claims and their engagement with international, and former colonial, audiences. For French repatriation practitioners, the ceremonies were the result of long negotiations but also gave them a better understanding of the implementation of Indigenous values inside a museum. The ceremonies testify to the transmission of traditional Māori knowledge and its adaptation to the context and the public. Differences exist between international and national ceremonies but also between international ceremonies. The expectations are different even if the result is common, that is, the return and commemoration of Māori ancestors. However, ceremonies held in France gain an unprecedented political or diplomatic dimension through their association with New Zealand.

\subsubsection{Hôtel de ville de Rouen 09-05-2011}

In 2007, the first attempt to return the Toi moko from Rouen was unsuccessful and seemed not to apply the same protocols as usual during a repatriation ceremony. Minchin reflected on his experience in his interview:

Because the Māori did not want it to be presented to the public. At the first restitution, we did not have the head on site. First, the ceremony has to be held at the City Hall, then we return to the museum and repatriate the head internally. The media did not want to come because they did not see the point if they could not see the head. And so we planned to return it afterwards. And the Māori delegation at that time did not want the head being publicly exposed. (Minchin, 17'min)

As a consequence, the first repatriation could be thought of as a diplomatic visit more than a repatriation ceremony. The repatriation was planned for later the same day at the museum with a restricted audience. Because the museum did not have much contact with the Te Papa team beforehand, French authorities did not really understand tikanga and protocols. The first ceremony seemed to have been hastily organised and did not follow all the legal process of decommissioning. Four years later, and after all the various steps taken to return the Toi moko legally were completed, media and public figures were finally present to support and cover the event. 
On the morning of Monday 9 May 2011, the director asked the museum staff to gather first at the Museum of Rouen. Although the ceremony occurred at the city hall, he wanted all the staff to go down to the city hall together. Police officers were also present at the entrance of the museum to accompany the Toi moko to the city hall. The intervention of the police surprised me at first glance. Maybe because the police do not interact much with museum practice on a daily basis, but also because the city hall is only located a few minutes away, down the road from the museum. The director jumped into the police car and we all walked down the street. The New Zealand delegation arrived only a few minutes after us. This ceremony was also a great opportunity to see Te Herekiekie Herewini (manager of KARP) and Michelle Hippolite (Kaihautū at that time) again, and this time not at Te Papa but in my birthplace. After the ceremony, the Māori delegation had the chance to visit the museum in order to see where the Toi moko had been preserved for all these years but also to remove the tapu from this institution:

Because we are quite independent from the exhibitions, we possible work together but we want to lift out our ancestors from overseas. Museums are not realising that we are doing this. When we are in a tangi within our community, part of the process of completing the tangi is you have a formal ceremony but also you go back to where the people live, and we call it the Takahi whare and also to clear the space. And it is actually what we are doing when we are overseas, we actually clear the space. And because our ancestors have been in those museums or institutions for a long period of time we say takahi whare. (Herewini, 55' $\mathrm{min}$ )

The ceremony took place in the room where weddings are usually celebrated. Because the museum was under the authority of the city, the municipality decided to organise the ceremony at the city hall and not at the museum. The room is spacious and was full of media with cameras all over the place. They were told to stay in a specific area during the ceremony but as soon as Sebastien Minchin and Te Herekiekie Herewini came into the room together bringing the Toi moko in the box, journalists followed them and surrounded the desk on which the Toi moko was then deposited. The kaumātua were singing a waiata in front of a camera close by and their personal space may have been jeopardised while they sang. Politicians and diplomatic personalities; mayors of Rouen (the former one, Pierre Albertini, who initiated the project and the present one, Valerie Fourneyron, who concluded the repatriation) were seated beside senators (including Catherine Morin Desailly), ambassador 
Rosemary Banks and director of the museum Sébastien Minchin. Other regional and national personalities from scientific and museum environments completed the tangata whenua side.

The Māori delegation was composed of Michelle Hippolite, Te Herekiekie Herewini, Te Kanawa Pitiroi and Kataraina Pitiroi. The museum had used the long period of negotiation and important media coverage to create a permanent exhibition and had invited a Māori artist to collaborate. His name was George Nuku and he was already working on the exhibition built at the Museum of Rouen but decided not to attend this ceremony for personal reasons (see chapter 4.5.1). The New Zealand Embassy invited Mokonui-a-rangi Smith, a Māori artist who was living in Paris at the time, to be part of the ceremony. He then became part of the manuhiri in front of the French delegation.

After a first meeting attended by the Māori delegation and city hall staff, the ceremony took place according to the pōwhiri protocols with few adaptations for the international context. Only one waiata was sung by each party after all the speeches and not after every single short speech, maybe because more French representatives spoke than Māori/New Zealanders. The French delegation decided to sing the French national anthem and the Māori delegation chose the himene (hymn) 'He Honore' which goes like this:

\author{
HE HONORE \\ He hōnore, he korōria \\ Maungārongo ki te whenua \\ Whakaaro pai e \\ Kingā tangata katoa \\ Ake ake, ake ake \\ $\bar{A}$ mine \\ Te Atua, te piringa, \\ Toku oranga
}

\author{
HONOUR \\ Honour, glory and \\ peace to the land \\ May good thoughts come \\ to all men \\ for ever and ever, for ever and ever. \\ Amen. \\ The Lord is the refuge \\ and my life.
}

\begin{abstract}
After the ceremony, everybody shared some food and drinks before leaving the city hall before lunch. This was also the moment chosen by the media to interview every person who had been part of the operation and the Māori delegation did not have much time to share their thoughts other than with journalists. The Māori delegation then were able to leave the city hall with the Toi moko and return to Paris with the team of the New Zealand Embassy.
\end{abstract}


Another repatriation ceremony was organised in New Zealand to receive the Toi moko at Te Papa on 4 May 2011 at 4pm. Many French representatives attended this ceremony mostly from the political environment such as senators, mayors and the French ambassador in New Zealand. Morin Desailly recalls this event:

We went through all the ceremonies, the dialogue, etc. We had tremendous success with my colleagues who can testify to this. My colleague from Wallis and Futuna, all my colleagues from the area were present to show that it was a mark of respect for the area including my fellow senators from French Polynesia and New Caledonia. We reconciled everyone and the ambassador when I arrived said to me: "you are my guardian angel", because he had to deal with so many issues including nuclear tests in the Pacific and a lot of other things to manage ... And also diplomacy, even if the goal was not that, I was there to answer a cultural, ethical question... (Morin Desailly, 18'min)

\subsubsection{Musée du quai Branly-Jacques Chirac 23-01-2012}

This ceremony is clearly the most important to be held in France in terms of the number of Toi moko returned but also in terms of the museums, media and people involved. Judging by the response of those present, this ceremony really established repatriation as a legitimate museum practice firstly because this event occurred in the Claude Levi Strauss amphitheatre of the MQB-JC. "The ceremony of January 23, 2012 was part of these attempts which appeared to me as successful and bringing change," Gagne remembered, "[i]t must be included in the long history of Māori struggles and their political project' (Gagné 2012, 23).

The MQB-JC answered all criteria required for the organisation of such an important event according to some political expectations. Due not only to its novelty and modernity but also thanks to its infrastructure, the MQB-JC appeared to be the perfect place to organise such an event. However, this national gathering of Toi moko also reflected the imbalance of power or pressure from Parisian museums against local museums (Van Praët, 89'min). In France, the MQB-JC is the only museum that receives its financial support directly from two ministries; the Ministry of Culture and the Ministry of Higher Education, Research and Innovation. In 2019, this association represented 79.4 per cent of the income, or 45.8 M€ (quai Branly annual report 2019, 134). Aside from the Toi moko from the Museum of Rouen, already repatriated a few months before, the rest of the collection of Toi moko known by public 
authorities had been gathered for this occasion from museums of Dunkerque, Lille, Sens, Nantes, Lyon, Marseille, the University of Montpellier and, finally, museums of Paris.

This imbalance of power could also be seen in the decision to allow only politicians and MQB-JC representatives to speak during the ceremony. No representatives of museums from other cities had been invited to speak. Some of them attended the ceremony but not as members of the tangata whenua side at the pōwhiri but as members of the public. This modern architectural building located on the banks of the Seine next to the Eiffel Tower has played a role of both national and international significance. The museum had faced considerable opposition towards its establishment but the repatriation process appeared to wipe away something of the bad image that had spread since its opening in 2006 (Van Praët 89'min; Price 2007; Alivizatou 2012; Gagné 2012). The Minister of Culture then in power, Frederic Mitterrand, attended this ceremony unlike the first ceremony held in Rouen. Even if Rouen's ceremony was the first, the Minister of Culture decided to attend only the one organised in the national capital. During his speech, the minister acknowledged Māori concepts involved in the process such as mana and self-determination (tino rangatiratanga). He also acknowledged the new relationships built on the repatriation and the creation of new field of research:

I thank our New Zealand partners for their availability for having maintained a permanent dialogue during the work of the French Parliament and the Museum Service of France (Directorate General of Heritage). It is up to me in this regard to emphasise that my ministry proposed to ensure the regrouping of the 20 Maori heads in Paris, thanks to the coordination work of Claire Chastanier and the authentication work of Michel Van Praet, then member of the Inspection general of museums. This dialogue allowed each step to circumvent any legal difficulties and to guarantee our convergence of views. (Mitterrand, 23 January 2012)

The MQB-JC appeared to be indecisive throughout the repatriation negotiations and received a lot of pressure from politicians and media to answer questions concerning its current involvement and also the general purpose of these procedures for all French museums. In answering those questions, the MQB-JC had to get closer to Te Papa and Māori communities. In my view, this is why the MQB-JC was chosen to organise the symposium in 2008 that is still considered to be the first meeting between French and New Zealand authorities. Hakiwai commented on this meeting as follows: 
During the symposiums at MQB, issues of repatriation surfaced, to return or repatriate regarding taonga but also the repatriation of ancestral remains so I think it has certainly helped in having a close relationship with the quai Branly and having a director that we built up a close friendship and rapport with who could actually help and facilitate and champion this kaupapa. (Hakiwai, 6'min)

On this occasion, French and international researchers and repatriation practitioners were able to meet and talk and try to gain a better understanding of the responsibilities and roles of museums in such a modern and global project. The ceremony lasted an hour. In the amphitheatre, invited persons could see the French delegation, waiting for the New Zealand delegation, on stage. Because this ceremony was held on stage, with lights in front of cameras and an audience, the event could be read as elevated from a cultural lecture to a highly solemn, almost theatrical, spectacle (Gagné 2012; Roustan 2016b). The stage and the amphitheatre were decorated by Māori portraits and two of them were displayed surrounding the ancestors as soon as they were deposited on stage. This effort to apply Māori protocols on stage created a few misunderstandings and some confusion which were observed by Gagné:

This feeling [sentiment of Māori moral superiority during this event] could also be reinforced by the fact that the hosts appeared on some occasions rather disconcerted, not always knowing how to react and what to do. Some confusion seemed to occur when accepting the koha (present), for example. This was also the case during the hongi. Some actions and words - I have identified some-from the French also appeared out-of-place. (Gagné 2012, 22)

The manuhiri appeared at the sound of the pūtātara (trumpet) and took their place in front of the tangata whenua as traditionally applies on a marae. Frederic Mitterrand (Minister of Culture), Catherine Morin Desailly and Richard Tuheiava (respectively senators of Seine Maritime and French Polynesia), Stéphane Martin (MQB-JC CEO) and other museum representatives comprised the tangata whenua. Derek Lardelli (kaumātua and member of RAP), Joe Harawira (kaumātua), Georgina Kerekere (kuia), Michelle Hippolite (Te Papa Kaihautū), Rosemary Banks (New Zealand Ambassador in Paris), Tamahou Temara (Toi Māori Operations Manager) and Te Herekiekie Herewini (manager of KARP) comprised the manuhiri. Mokonui-a-rangi Smith was also invited to attend the ceremony and sat behind Te 
Papa's delegation. This same delegation was also promoting the work of Toi Māori Aotearoa: Māori Arts New Zealand.

The date 23 January was chosen to complete the ceremony because it coincided with the closing of the exhibition Màori: Leurs Trésors ont une Ame. During the last week of the exhibition, several artists from Aotearoa had been invited to perform in the MQB-JC. For that reason, the highly regarded personalities who comprised the manuhiri during the ceremony had also been working closely with artists and museum practitioners, such as kaitiaki, in order to look after the taonga, and ancestral remains, and to provide more background context about Māori arts. Well known Māori artist Derek Lardelli and six other tattoo artists had facilitated workshops in order to pass on accurate information about the well-known practice of tā moko. All in all, the ceremony was not only a commemoration of ancestral remains but an acknowledgement of tangible and intangible heritage from the Antipodes. The association of the exhibition with the repatriation ceremony gave a better understanding of the richness of Māori culture and presented contemporary cultural and political claims affiliated to artistic expression, whakapapa, and tino rangatiratanga.

\subsubsection{Te Papa 27-01-2012}

The repatriation ceremony for the 20 Toi moko returning to Aotearoa from French collections was initially scheduled for the late afternoon of 26 January. Unfortunately, unsafe weather conditions prevented the aircraft that was carrying the Māori delegation and the remains from landing at Wellington Airport. Consequently, the delegation returned to Auckland and then returned at dawn the next morning. In order to avoid carrying out the ceremony during opening hours, Te Papa's team and their guests gathered at 6.30am inside Rongomaraeroa marae. They were ready to welcome the French delegation, represented by the ambassador and his team, accompanied by the Māori group who made the trip to Europe. This last group comprised the manuhiri and this same Māori delegation who were advising French representatives on the protocols throughout the ceremony. They all gathered at the bottom of the external staircase leading directly to the marae located at level four of Te Papa's building. At the sound of the pūtātara and pūkaea, the ceremony began. The Māori and French delegations climbed the steps of the staircase in light rain, taking with them the 20 boxes that 
contained the heads of tūpuna. On their arrival at the top of the stairs, they walked through the named waharoa or gateway on the marae-ātea (courtyard) of the marae, accompanied by the tears and cries of the the kaikaranga and representatives of the Tainui iwi and the team of Te Papa who greeted them and invited them to enter the marae. It was a very emotional and moving occasion for those present.

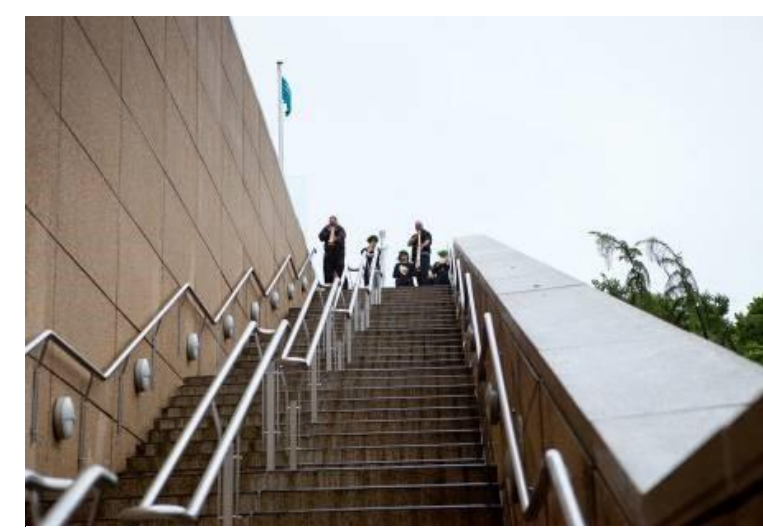

Figure 6 Pūtātara and pūkāea announcing the ceremony @ Norman Heke, Te Papa, 2012.

During this karanga or keening call of welcome, I felt that sympathy, respect and peaceful

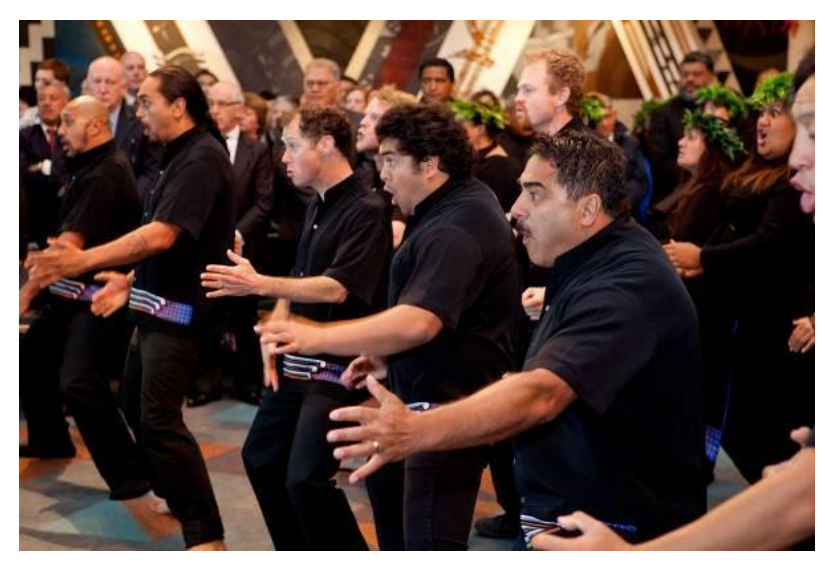

Figure 7 Haka pōwhiri (C) Norman Heke, Te Papa, 2012. states of mind could be sensed emanating from both parties - manuhiri and tangata whenua. This occasion was one of the most important Māori ceremonies in which the current team of the French Embassy had taken part. Given the number of people invited, and the presence of certain leaders or politicians and the media, this occasion demonstrated the importance of whakapapa and the key role of Te Papa and its marae in the completion of such a project. Hema Temara led the tangata whenua and I was lucky enough to be a member of this group to welcome the French delegation to Te Papa. Despite the novelty of the repatriation context, the procedure applied a protocol inspired by tangihanga and pōwhiri.

LEADER: $\bar{A}$, tōia mai,

CHORUS: Te waka!

LEADER: Ki te urunga, CHORUS: Te waka!

LEADER: Ki te moenga, CHORUS: Te waka!

ALL: Ki te takotorunga, Takoto ai, Te waka!! 
The haka performed for this occasion was the well-known Ngāti Toa haka 'Ka Mate' performed by the All Blacks. It was performed in front of members of the French Embassy, and I could feel their reactions of intimidation and humility. Being invited to stand alongside the tangata whenua and perform the haka to my countrymen was a strong gesture of collaboration with my Māori friends and colleagues. By allowing me to be part of the ceremony as a Te Papa staff member not only acknowledged my personal involvement in the process but also honored my entire journey taken to understand how tikanga was fully part of repatriation.

After depositing the boxes on the platform of the wharenui, where women were weeping and sobbing, the manuhiri took their places opposite the tangata whenua, made up of members of Te Papa staff and the Tainui tribes. During the pōwhiri, the two first rows were reserved for special participants. The first row is traditionally reserved for speakers such as kaumātua, ariki and leaders in private or professional

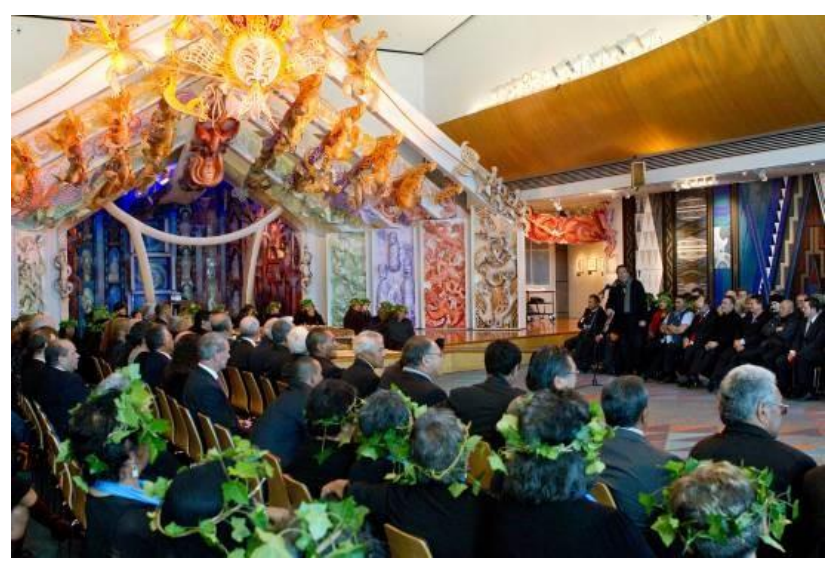

Figure 8 The tangata whenua in the foreground facing the manuhiri @ Norman Heke, Te Papa, 2012. spheres. Usually, only men speak during pōwhiri. Again, in the past, wives of leaders therefore occupied the second row. In this way, the men of the tribe who participated in this event spiritually protected the women. From the third rank, men and women shared the same rank without difference of status or other distinctions (Tauroa and Tauroa 1986, 54).

During this ceremony, we noticed the division of individuals into three distinct groups: the manuhiri, the tangata whenua and the mourners. Sitting on the platform of Te Hono ki Hawaiki, mourners draped the ancestors caskets with kāhuhu (cloaks) generally made of kiwi feathers, bird feathers and flax fibres. All kahu used during the ceremony are part of the Māori collection of the museum, but these taonga are able to be used for special occasions like this. 
Each whaikōrero is a speech made by a different person. On this occasion, tribal leaders and kaumātua gave speeches along with the CEO of Te Papa. Māori representatives and the French ambassador spoke for the manuhiri. Although the speakers spoke with vigour and conviction, the goal was not to intimidate the other party but to welcome the 20 ancestors back to their land and

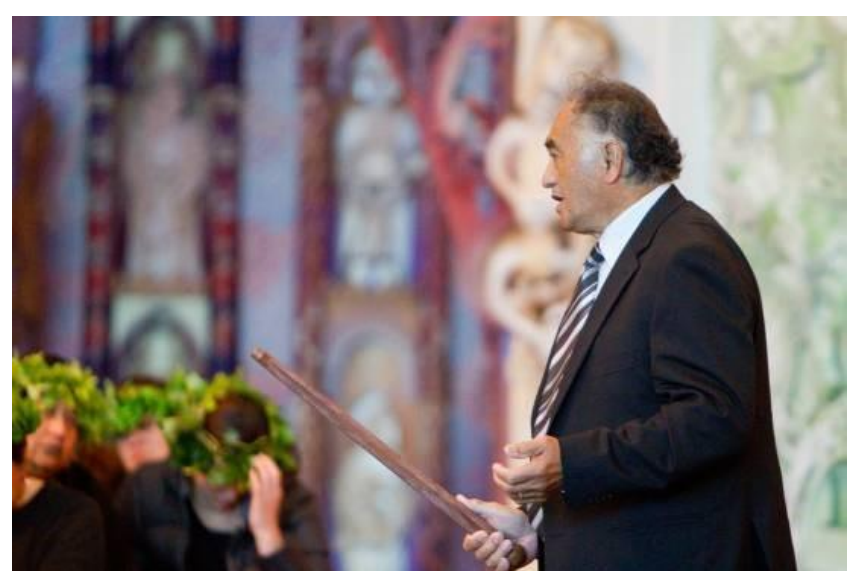

Figure 9 Whaikōrero by Te Kanawa Pitiroi @ Norman Heke, Te Papa, 2012 acknowledge the role of the French and New Zealand authorities in their return. The first speeches are of course never in English or any other foreign language but only in te reo Māori to prove to the ancestors that they are indeed back in Aotearoa and, in particular, on the lands of Te Whanganui-a-Tara (Wellington). The French ambassador was the last speaker for the manuhiri. He introduced and concluded his speech in te reo.

Between each speech, members affiliated to the speaker sang a waiata (song) to conclude the speech. 'Te Hokinga Mai' was one of the waiata sung by the Te Papa team after the French and English-speaking intervention of the director Michael Houlihan, which goes as follows:

\section{TE HOKINGA MAI}

Tangi a te ruru

Kei te hokihoki mai e

Te whakawherowhero I te Pūtahitanga

Naku nei rā koe

I tuku kia haere

Tērā puritia iho nui rawa te aroha e

Te hokinga mai tēnā koutou

Tangi ana te Nga kau i te aroha

Tū tonu rā te mana, te ihi

O ngā tūpuna kua wehe atu rā

Mauria mai, te mauri tangata

Hei orange mo te morehu

Tangi mōkai nei

E rapu anai i te aratika

Mo tātau katoa (x2)

Te Hokinga Mai,

Te Hokinga Mai

Tū tangata ton $\mathrm{u}$ !

\section{THE RETURN}

The cry of the morepork

keeps coming back to me.

It is hooting out there

where the paths meet.

I was the one

who allowed you to go.

It was curbed,

my deep love for you

But now the formal return home; greetings to you,

How my heart weeps, with joy.

Still standing tall is the prestige and the enchantment of the ancestors who have passed on.

Bring back the true spirit of the people

to help heal the survivor

crying like a slave (i.e. with

loneliness)

and searching for the true path 
for us all.

Te Hokinga Mai- Return home!

Te Hokinga Mai- Return home!

Stand tall!

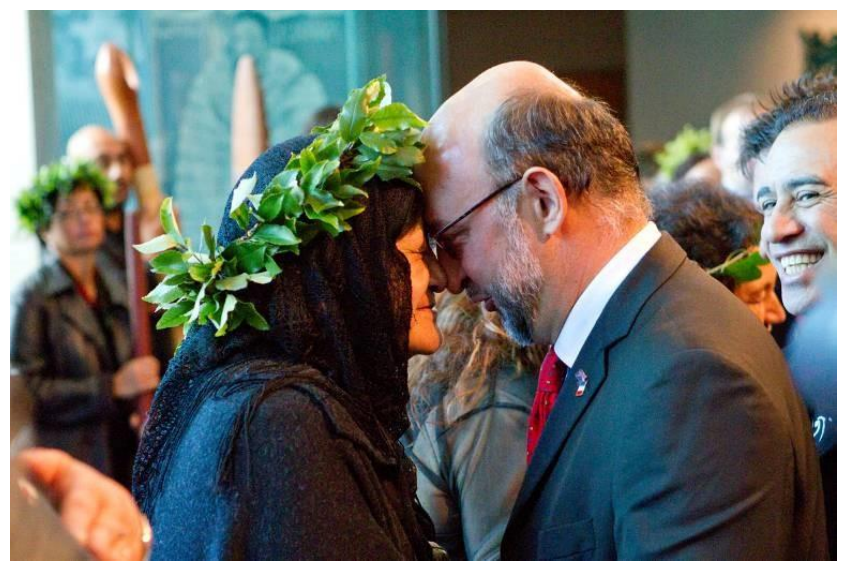

Figure 10 Hongi at the end of the ceremony (C) Norman Heke, Te Papa, 2012.
This is only an example of a waiata, but maybe it is the most representative of Māori involvement in New Zealand museums, as we saw in Chapter Three. The waiata, or chanson Française, chosen by Francis Etienne and his diplomatic team corroborated the cultural dimension and the mutual respect shown throughout the French ambassador's speech. After the speech, which ended on a humorous note about the strength of the wind in Wellington, the French delegation rose to sing the words of 'Qui peut faire de la voile sans vent' (Who can sail without wind), a French nursery rhyme chosen for its opportunity to show the compassion and sharing aspects that characterised this day of ceremony. The manuhiri was then invited to perform the hongi, to mark the end of the ceremony, and to remove the coffins and place them in the wāhi tapu (sacred place), where they will remain until they are returned to their people. Every ceremony concludes by sharing drinks and food in order to open discussions among the two parties. Because the food is noa, unrestricted or free from the extensions of tapu, the food has a key part in lifting clearing away the tapu dimension of the human remains from the persons who participated in the ceremony.

\subsubsection{Repatriation of the poupou Tītokowaru 28-10-2013}

KARP mainly focuses its research on human remains but it may receive some requests concerning other objects or treasures that are contained in overseas ethnographic collections. Thanks to the contact established by French and New Zealand authorities, one poupou was at the centre of a repatriation operation. This poupou initially adorned the walls of a wharenui and they usually honour an ancestor or a god (atua) to whom the tribe or group occupying the marae attaches particular importance. Tittokowaru (c.1823-1888) is an ancestor who is 
commemorated on one of these carved panels (Hardwood 2014, 16). He has a full facial moko and carries in his right hand a patu or mere. He wears two white feathers of a huia bird as a hair ornament.

Objects located in foreign museum collections do not lose their value because of their distant geographical location. They might be forgotten over time but to descendants they are still taonga and embedded with the definition of such treasures. Taonga are not only the representation of an ancestor, but also hold a part of the ancestor's wairua or soul (Mead 2003, 70). From this perspective, this poupou contains the spirit of Tìtokowaru. Taonga are also considered to be objects with great esteem due to the historical value conferred on them. These items constitute physical proof of the oral histories transmitted from generation to generation and enable the recall of certain historical facts. The taonga thus serve as time markers to maintain the role of the community in a constantly changing society. Another example is the taiaha of Te Rauparaha. Chief of Ngāti Toa, he created the well-known haka 'Ka Mate' mentioned above. In the back-of-house area of Te Papa, on one occasion when I was present as a translator/guide, this taonga was shown to the French rugby team in June 2009. Because of the value of the weapon, karakia were performed before and after its exposure to a limited public, and, naturally, in a museum no one except kaitiaki could touch it. Kaitiaki presented this item as a taonga and explained to the rugby team the importance of considering the treasure not only as an object but also as a memory of an ancestor.

At first, the information in the possession of Te Papa researchers related to the foreign acquisition of this poupou Titokowaru was limited. According to the information found in the archives of the Colonial Museum (now Te Papa), the poupou became part of the collection in 1905 (Hill 1904-1905 cited by Hardwood 2014, 19). However, Hokimate Hardwood, researcher in charge of this case, found out that the poupou, along with nine other taonga listed, had been sent to Paris around 1953 as a loan for the newly created New Zealand Embassy (Hardwood 2014, 21). In 1982, a first request to return was made by the National Museum in Wellington but it was decided to leave the poupou in Paris due to its size and the expense involved in its return (Hardwood 2014, 21). Before I left for New Zealand in 2011, I had noticed this carved piece many times on a wall in the embassy reception area without knowing that it would be the object of an official repatriation. Having found the carving, Te Papa asked the New Zealand ambassador about the possibility of returning it to Wellington and a ceremony was scheduled for October 2013. 
On the morning concerned, the Māori delegation gathered in the embassy hall in Paris to conduct the restitution ceremony. On this occasion, the group was composed of two members of KARP and two kaumātua (elders). It is important to note that the room where the ceremony took place was regarded as a marae. Like the museum amphitheater or the city hall, the ambassador's residence became a functional marae during the time taken to complete the ceremony. This flexible use of space is quite common.

Many people use the term 'marae' for any place where they choose to welcome visitors, especially when they choose to use a format corresponding to that of a marae welcome. A room, therefore, may loosely, though acceptably, be referred to as a marae for the purposes of welcoming visitors. (Tauroa and Tauroa 1986, 141)

The ceremony began with a quick meeting between Te Papa's delegation, the ambassador Rosemary Banks and members of the embassy, two members of MQB-JC and myself. This meeting aimed to answer any questions and summarise all the stages of the ceremony that were to take place in the ambassador's residence next to the Embassy. One aspect particularly raised attention. The carved piece was placed, if we refer to the plan quickly drawn by Rosemary Banks, between the tangata whenua and the manuhiri. The situation annoyed the two kaumātua who preferred to see the taonga placed at the back of the room in order to prevent the living from speaking above the taonga, which would have been a breach of protocols. The space allocated for this ceremony did not allow for completely removing the taonga already in his case, but members of MQB-JC moved it slightly to avoid anyone speaking above his head during the ceremony.

When the discussions were over, we prepared ourselves for the ceremony. The manuhiri, comprising the Māori delegation, members of MQB-JC and myself, crossed the garden separating the embassy from the residence. To the sound of the pūtātara we entered into the house and the ceremonial hall. The kuia was our leader and sung a waiata to signal the start of the ceremony. We followed her in a specific order: the kaumātua then Te Herekiekie Herewini, Te Arikirangi Mamaku, the members of MQB-JC and finally myself. The tangata whenua comprised members of the embassy. Each of us was dressed in black or wearing a black accessory, in order to honour the spirit of Tìtokowaru.

The waiata that we performed aimed to demonstrate to the tupuna (ancestor) instantiated in the carved taonga that he was no longer alone from now on and he had begun his return to his 
homeland from that moment. We sat down facing the tangata whenua to start the kōrero of each of the leaders. The kaumātua took the first place at the end of the row of chairs, closest to Tìtokowaru and all the men of the manuhiri took their places beside him. At the end of the ceremony, MQB-JC's representatives put Tìtokowaru into the car and drove straight to the airport with Te Herekiekie Herewini. All the other people stayed a little bit longer to share some food and drinks and express our appreciation of the return.

\subsection{Secularism in museums and Māori repatriation ceremonies in French public institutions}

On 9 December 1905, and initiated by the deputy Aristide Briand, the French government voted on a law that separated the Church from the State. This duality of powers was manifest throughout the evolution of French history and implemented in modern times by Napoleon and his Concordat in 1801 . This major decision from the early $20^{\text {th }}$ century meant that the government would not represent or finance any religious cults. In 1958, the concept of secularism even became a fundamental principle of the French constitution. In my education, the concept of secularism was taught strenuously, maybe as strenuously as the famous "Liberté, Egalité, Fraternité". Although the Republic allows liberty to belong to every citizen (art.1), all the financial support previously provided to the Catholic Church by the state, regions or cities has been removed from governmental budgets (art.2). The decision to separate the two groups was made in order not only to respect other religious denominations in France but also to remain neutral in terms of legislation. The definition of secularism in the dictionary would be "Concept and organization of society based on the separation of Church and State and which excludes the Churches from the exercise of any political or administrative power, and, in particular, from the organization of education" (larousse.fr, accessed 28 May 2020).

Despite the current debate around the wearing of the hijab in public places, in the context of this thesis secularism is relevant in terms of museum practice in France. Every public institution has to remain secular, including museums. This principle could be quite difficult to apply when French professionals work with professionals from the communities of origin of artefacts in the collection. The repatriation ceremony held at MQB-JC in 2012 is an example of adaptation. The participation of Indigenous groups in French museums has raised the issue of religious neutrality, according to some detractors and the media (Gagné 2012). The repatriation ceremonies are surely not the first 'spiritual' events that have happened in a 
French museum or institution, but it seems that the dramatic choices made by the city hall of Rouen and the MQB-JC to carry out the ceremony in front of cameras had some consequences for the confused interpretation of the event. Furthermore, the museum policies inherent in hosting these ceremonies at the same time as exhibitions, like the permanent exhibition in Rouen or Māori: leurs trésors ont une ame in Paris, reflected this duality between two museologies - the New Zealand collaborative approach and the French interpretative authority. The strong control over the taonga held by Māori curators may have created an ambiguity between French interpretation and Indigenous collaboration (Roustan 2016, 166; Boulay 2019, 26’min).

The experiment in the new collaborative museology eventually adopted by French museums, which could be considered to be an outcome of the repatriation operation, was also their first experience with a Māori community. The Museum of Rouen worked with Te Papa in terms of information on taonga but also worked extensively with George Nuku, an artist who was charged with carving and assisting the staff in the museology 'in the field'. This decision to interact mainly with one person allowed the museum to understand the personal perspective of the artist on rituals and pōwhiri. In 2015, when the museum participated in a festival of contemporary arts from the Pacific and also opened a temporary exhibition created by George $\mathrm{Nuku}$, the French staff, the director of the museum and cultural representatives all became more aware of the rituals and protocols applied during a pōwhiri.

Secularism could also be one of the major differences between French and New Zealand museums. At Te Papa, tikanga Māori are observed daily and are spiritually ubiquitous. Any events led by the Māori team, such as pōwhiri, opening or closing ceremonies but also staff functions, commemorations, etc. are all carried out with strong Māori values. During my last week of internship in 2012, the Ngā Manu Atarau and Mātauranga Māori teams organised a hui in order to acknowledge my work and my personal involvement in the repatriation process. In French museums, however, things are very different, and secularism is applied according to the staff and the context, as I explain below.

\subsection{Toi moko as living artefacts in post repatriation collaboration}

\subsubsection{The permanent exhibition in Rouen 2011}

Among French museums, the Museum of Rouen is currently the one that has maintained the longest relationship with KARP, from early negotiations to the creation of a post-repatriation project. As an initiator in France for the repatriation of Māori ancestors, this museum was able 
to establish a long-term relationship with the programme that generated an opportunity, for both institutions, to work on elements other than Toi moko remaining in the French museum. For 11 years between 1996 and 2007, the museum ceased exhibiting their ethnographic collections. The funding difficulties for the restoration of the building, classified as a historic monument, led to the final closure to the public of the fourth floor where Māori treasures were once displayed. The director of the museum and its curators considered their understanding of the taonga to be insufficient for them to be displayed to the public, according to the new mandate given to the museum by the city of Rouen. Through repatriation, the museum's staff, supported by their municipal administration, hoped to create opportunities to have more contact with Te Papa and increase their appreciation of collections that originated from the South Pacific Islands. The purpose was not to return all the treasures but to teach French museum professionals, and consequently the public, about artefacts from some of the cultures from that part of the world.

The international stature of the bicultural model at Te Papa has heavily influenced the completion and success of this project for the museum in Normandy. Thanks to the repatriation process, the Museum of Rouen was able to bring the collections from the Pacific to light and to implement the vision of several kaitiaki from New Zealand museums. This project therefore shows a reflexive way to present the natural history museum as a "sustainable and responsible" institution according to the new functional specifications that were voted on before its reopening in 2007 (Morin Desailly 2019, 2'min). On a broader scale, this new project became an example of a modern, inclusive museology with regard to objects and taonga acquired during the colonial period. As explained previously, this type of museology tries to reconcile French museums with their colonial past by using the same techniques originally developed during their major collecting phase(s). This cultural project seeks to present the collection in association with Indigenous knowledge(s), gathered and shared by contemporary Indigenous researchers. In July 2010, the museum hired Julia Ferloni especially for this project. As the Curator of Ethnographic and Oceanian collections, she was asked to carry out an inventory and conserve the taonga (Minchin 2019, 32'min; Boulay and Ferloni 2011, 100). This work helped the museum to improve on and, in some cases, not only fix the poor conservation conditions but also to gain a better idea of the objects in the collection and those for possible selection for the planned 'gallery of continents'.

During the same year, the museum was in full negotiation with KARP to return the Toi moko donated in 1875 by Drouet. These contacts enabled the museum team to gain more knowledge 
relating to these artefacts, not only those belonging to Māori, but also to all Oceania collections in partnership with curators of the Pacific collections at Te Papa, who contributed to the evaluation of these objects. The repatriation ceremony held at the Hôtel de Ville in Rouen on 9 May, 2011, did not put an end to this project but actually was an opportunity for the repatriation practitioners from both countries to meet one another in person. The display of objects from the perspectives of kaitiaki enabled the French museum to present an exhibition based on collaboration, and has subsequently led to the creation of a space dedicated to Indigenous worldviews. Puawai Cairns from Te Papa commented:

I mean Rouen, even if it was a little bit institutional, it was still a koha and response to Rouen giving us something back, so you have to give something back to them as well. It is a balance; it is a dance. So we operate, as long as repatriation is grounded with Whakaaro Māori, and not whakaaro Coloniser, it is going to be an interesting scene how things are going. (Cairns, 59'min)

In order to show links between the objects displayed, the French museum decided to present the collection under six different themes that reflected and connected all of the objects in the collection: Communicating with the Gods, Being Beautiful to Show one's Identity, Objects of Power- Objects of Chiefs, Exchanges with Westerners, The Discovery of Oceanic Fauna, and finally, Māori Community. The last theme was the culmination of the relationships presented in the other themes, and showed this by presenting the various Māori taonga according to the vision of the Te Papa curatorial team. With the help of labels presented in digital form alongside each display case, the Museum of Rouen inserted the comments and interpretation shared by all the participants, French and New Zealanders, who help to set up this permanent exhibition.

The input by the New Zealand team is easy to see in the final exhibit in the galleries, according to my observation of this space. It is clear that the display has a different feel thanks to the use of appropriate Māori terms for each object and the names of communities that all objects, stories or pieces of information are affiliated with. We know that the Māori collections of the museum were donated for the most part by Admiral Cécille, commander-inchief of the frigate Heroine who landed at the Bay of Islands in 1837. The admiral arrived on the coast of Chatham Islands where he destroyed several Māori villages and took various objects after that assault. The name of each object, their spiritual and intellectual significances 
and other information about taonga and their functions were analysed and shared by KARP and the RAP.

\subsubsection{George Nuku: The practice of an inclusive museology}

Thanks to the historical architecture of the building, the Museum of Rouen is 'a museum inside a museum'. They chose to keep a certain tradition in museology but also to challenge it by adding new content throughout every exhibition. To decorate each display case in the displays, the museum called upon Māori artist, George Nuku, from Ngāti Toarangatira and Ngāti Kahungunu iwi.

Settled in the UK and Europe for many years, George Nuku is an artist working particularly with so-called "non-noble" materials, Plexiglas and polystyrene. His work in the galleries responded to the museum's desire to enhance the collections while letting this artist express his connections with Aotearoa through his art works. For the first four windows, George Nuku created several panels representing six singular entities mixing the artistic styles of several Indigenous communities. Although they are inspired by Polynesian artistic influences, these works are not representative of the tradition of these communities; they above all express the eloquence of the artist in connection with his own vision of the development of ethnographic objects. Staff commented on his artistic intervention as follows:

It's very interesting. Because when I invited him, he was in England and we could contact him thanks to Claude Stefani, in Rochefort, who invited me with Roger [Boulay]. Claude had wanted to invite him for quite a while, and he gave me his details. I sent him a message and George answered me, by saying that he wants to come, that it is not far from England. He was still married to Maia who was at Cambridge. They both came. I talk to elected officials, not one makes the effort of coming, neither did the media, and I told him with a little pride that I led the repatriation of the Māori head. And there he looks at me and tells me that he is against this... Oh s*** !!! And at the same time, I tell myself it doesn't matter, the museum is a place of debate, as a non-specialist I am in favor and him, as a Māori, is against. Let's work together. (Minchin, 25'min)

Nevertheless, George Nuku produced several pieces responding to the commission from the museum. He embedded the pieces of a waka in his works, thus developing a continuity between historical objects and his modern work. For the back of another display case, he 
depicted Tūmatauenga on a polystyrene support. The god of war, his face performing a pūkana illustrates weapons such as the taiaha exposed on the front of the window. Finally, for Oceanian fauna, he represented a flight of birds which describe the richness of the natural world in each of the Pacific Islands.

George Nuku put into practice a new form of museology at the museum but he also contributed to the debate on restitution. He was unconvinced by the repatriation project in its current form. Because these heads were technically traded, the question of repatriation remains sensitive, according to him:

When it is about theft, then yes, you have to return what was stolen. And it's good for everyone. But for us, from my point of view, asking for the repatriation of human remains is not a point of view that I share. I respect the point of view and the good intentions of the Māori who want these remains as I respect the points of view of the people who worked for this restitution to take place. But there are several points of view. (Nuku, Film Festival Rochefort, Round table 2013, 94)

The protocol of the current repatriation ceremonies requires that these heads, which are no longer observable in their entirety, should be placed in a coffin. For Nuku, the pride of belonging to the Pacific community should mean that it is best not to hide the head but to show it as it is today (Rochefort 2013, 95). In the context of the exhibition in Rouen, his point of view sparked a debate among museum staff. Through his presence in France and the reception of his work at the museum, George Nuku had the opportunity to fuel this debate around human remains and their functions in Western museums. The position he maintains on the subject of Toi moko illustrates the diversity of opinions concerning repatriation in general. The decision by the Museum of Rouen to give free rein to an artist and to researchers whose origins are the same as the collections being displayed characterises this new museum trend, new to France, but increasingly being adopted by certain international cultural institutions.

In this case study, the establishing of relationships between Māori researchers and French professionals has influenced museum activities, both in the field of preventive conservation and the exhibition of objects and their importance for Māori. In this context, the Museum of Rouen wanted to put itself to the test by being a place where scientific debates could develop. The questions relating to the place of human remains and to the Western perspectives held on ethnographic collections are, however, not resolved by this single project but it is clearly an 
example that repatriation can generate other projects inside a museum and between museums. The repatriation project helped advance French debates and legislation concerning human remains in public institutions such as museums. Although each case of repatriation of Toi moko remains unique, the position of the Norman museum in Rouen has been elevated by this long-term collaboration which has enabled museological foundations to emerge from the exhibition. The momentum generated by this project may have had an impact on the Museum's care and understanding of ethnographic objects from other regions of the world. The later creation of the 'gallery of continents' by the museum team shows a commitment to keep the same guidelines concerning the participation of communities of origin. In the 'Asia' section of this gallery, an Indonesian artist was invited to create art similar to that of George Nuku in terms of creating visual representations of cultural objects, ideas and principles.

After the law in favor of repatriation was voted on, a common desire to establish relations with communities of origin emerged in French museums, thus encouraging further research on the collections. The second repatriation ceremony held in January 2012 is a good example of this enthusiasm. The ceremony at MQB-JC was organised to symbolically mark the end of the temporary exhibition Māori: leurs trésors ont une âme. This exhibition was also a reflection of the new collaborations between French and New Zealand museums. It was worked on mainly by Māori professionals and initially exhibited in New Zealand. This promotion of a culture by its stakeholders has reinforced the idea of an active participation of Indigenous populations in the management of their treasures, even on an international scale. In addition, it should be emphasised that the exhibition managed to adapt to new contexts by making some modifications to what was displayed to the New Zealand public, for later display to a less informed French public, as I show in the following section.

\subsubsection{E Tu Ake at MQB 2012-2013}

The exhibition Māori: leurs trésors ont une âme opened in Paris at the MQB-JC on 4 October 2011. It was originally staged under the title E Tü Ake: Mãori Standing Strong at Te Papa between 2010 and 2011. After a pause, the exhibition began an international tour during which it was presented in France for three and a half months before being exhibited in Mexico in 2011 and finally in Quebec in 2012 (Davidson and Castellanos 2019, 191). In the French museum, this exhibition embodied the very first collaboration with Te Papa dedicated to an entire project. E Tu Ake was an exhibition created in New Zealand and developed with the contribution of the tribal descendants of the taonga chosen for inclusion. MQB-JC and Te 
Papa collaborated for the first time in the Paris gallery. This partnership was not simply associated with this exhibition but was in fact initiated by the repatriation of the 20 Toi moko from French institutions including 7 from the MQB itself (Jean 2013; Gagné and Roustan 2014).

However, despite the finality of the ancestors' return, the MQB-JC seemed initially opposed to the repatriation of the seven Māori heads from the collection. In this context, repatriation negotiations could also be considered to be an asset in the project of presenting $E T u A k e$ in Paris. Repatriation preparations for the exhibition helped strike a balance between the interests of the two museums. The MQB-JC had apparently taken advantage of the opportunity opened by the repatriation to work with Te Papa to resolve the ambiguity of human remains in French national collections. Herewini from KARP explained the situation as follows;

I think many things were happening and I think the repatriation was part of the package. And also, there were representatives from Toi Māori, it was seen as quite an important event from a New Zealand perspective, from a Māori perspective and from a French perspective. Rouen was the first but the MQB actually allowed for multiple things to take place. (Herewini 2019, 20’min)

Located halfway around the world from New Zealand, and housed in a large, new building designed by Jean Nouvelle near the Eiffel Tower in the centre of the French capital, the MQB-JC is famous for its spectacular exhibitions of ethnographic material displayed with a distinctive aesthetic design that has been much debated (Price 2007). The Te Papa team responsible for the journey and display of the taonga in France were particularly satisfied to be able to work in a larger space than was initially allocated to it within the walls of Te Papa a few years earlier.

In 2010, a team from the MQB-JC went to New Zealand to discuss the dimensions and scenography projects that would eventually be part of the exhibition within the Paris museum. It was the first meeting between the two teams. This meeting was also the first major opportunity to raise any concerns about the objects and the balance of authority between the two international institutions. The collection presented in Paris included 155 objects of which 118 were ancestral taonga, the majority of these artefacts had never left New Zealand. In the exhibition space, taonga were associated with contemporary works, photographs and other 
objects from today's material culture, including tables and paper towels. The combination of modern art and everyday objects may have surprised some French visitors, who may have expected more common museography in Europe, based on a presentation of Indigenous people 'as they were'. On the other hand, the combination of old and new elements of Māori culture is quite a common approach in terms of exhibition in New Zealand. This deliberate mixture of old and new in France pointed to an approach now common in post-settler nations like New Zealand and Australia for displaying Indigenous material culture, linking the past and the present in contrast to traditional ethnographic exhibits still common in European museums. The examples of Te Papa iwi exhibitions (see chapter 3.1.3) gave a modern perspective that MQB-JC did not yet have at that stage of the collaboration. The temporal links of a cultural identity also lie in its material form, connecting the past and the present. Those types of exhibitions are favored today by the museums in New Zealand, in contradiction with the traditional ethnographic exhibitions still common in the countries recognised as being part of a former colonial empire (Jean 2013).

This type of collaborative exhibition remains popular in New Zealand thanks, in particular, to the impetus given by Te Māori, the first international travelling exhibition recounting Māori history (see chapter 3.1.2). Among the influences resulting from this first instance, a delegation of Māori elders accompanied the Te Papa team to France to protect and maintain the collections and to carry out the various ceremonies intended to protect the tapu of these taonga (Mead 1984; McCarthy 2007, 2011). The inclusion of these important ceremonies and the texts presented on the labels gave the French public an opportunity to better understand the messages conveyed by this exhibition about the cultural continuity of Māori taonga and their political implementation. The objective of this event was not to present the information as 'folklore' nor to enhance the experience of looking at precious historical objects without any explanation. Rather, this project attempted to explain and make clear the current fight for self-determination of Māori, expressed in the former title E Tū Ake: Māori Standing Strong.

However, some issues were highlighted concerning the changing of the title and some parts of the English and Māori information initially included. E Tü Ake: Māori Standing Strong was changed into Màori: Their Treasures have a Soul. The space had been divided into four sections organised around four concepts: tino rangatiratanga, kaitiakitanga, whakapapa, and mana (self-determination, protection, genealogy and spiritual authority) (Smith 2011). These terms are founding values that are still alive in the constitution of contemporary Māori cultural identity and in the Māori worldview. These concepts have key importance on an 
everyday basis but also play roles during the repatriation process and in negotiations. The objective of reaffirming Indigenous beliefs through this international event was achieved by the installation of numerous explanatory panels and labels. This exhibition also presented a body of text explaining the context in which this cultural emergence resurfaced, and the resulting tensions through the ongoing decolonisation period. It was not only a question of developing an exhibition of objects but of transmitting an appropriate vocabulary, in order to understand Indigenous positions.

And so it was developed to taken off shore. It was kind of an Introduction to Māori political ironism and the role that culture plays on politics.

The grounding of politicised nature in Māori life and how that relates back to our material culture. Because it was developed for an international audience, it was a panoramic exhibition. (Cairns 2019, 16'min)

In addition, the French translation of the labels had to adapt to meet the needs of an audience that was very unfamiliar with the terms in use and with Māori culture in general. The exhibition Māori: Their Treasures have a Soul could not be presented in the same way in France and New Zealand, in particular because of the divergent expectations of these two institutions and their audiences. In New Zealand, the aim of the exhibition was to trace the history of Māori self-determination by presenting case studies of past conflicts and attempting to describe the evolution of the struggle with the government. In France, the main objective was to help grasp the understanding of the overall position of the Māori community in New Zealand. The French institution had not planned to express a point of view on the political situation in New Zealand, but to present the Māori community through its art and its adaptation throughout its colonial history.

The project Mãori: Leurs Trésors ont une âme first took shape under the name of Mauriora, exhibited in Japan in 2008 before being reworked for a New Zealand audience with the title $E$ Tü Ake: Māori Standing Strong in 2010 to 2011. In Paris, the title once again evolved in response to the desire to communicate with a French audience more clearly and to appeal to a wider audience, adults and children alike, regarding the uniqueness and richness of the collection presented. It was feared that a literal translation of the English title would express a radical political connotation at the expense of greater freedom of interpretation left to visitors.

However, it seemed to me that, as the visit progressed, the guidelines presented in Paris moved away from the reasons for which this exhibition was initially created. In its 
presentation in New Zealand, E Tu Ake embodied an attempt to re-establish the complex cultural issues being debated among the audience. This initiative was part of a desire to make the young Māori generation aware of these same issues. It is recognised that Māori under the age of 25 are not as sensitive to these issues as the older generation as a result of the influence of a relatively different way of life, socially or politically (Mead 2003).

Through this exhibition, the French audience were able to express interest in the contemporary social and political realities of the Māori community, contributing to an evolution of a possible 'neocolonial' vision of European museums. For this reason, the Māori curators played a key role in the relationship between museums for the duration of this project. The staff from the two institutions considered that the participation of Maori professionals enabled the emergence of an innovative museum practice, thus strengthening their respective international reputations. Building on the bicultural policy of Te Papa, the preservation of taonga is supported by the defining Māori concepts, so that Māori professionals can work in partnership with the tribal groups of origin in the development of the exhibitions.

The objective of this exhibition, in France as in New Zealand, was to raise public awareness of issues such as self-determination (tino rangatiratanga) and to demonstrate that the Māori community is still alive and prosperous, and shows real cultural dynamism. Some media articles have criticised this event, claiming that it was not representative of modern Māori culture despite the fact that one of the objectives was to educate the public about past struggles and their effects on the current Indigenous cultural identity in New Zealand.

The question may be posed: Was the exhibition able to achieve its goal of changing public attitudes and combating stereotypes about Māori culture? Visiting these galleries and observing the reaction of the public led me to think that many people were able to discover Māori culture as a whole and deepen their knowledge of the customs and the relationships maintained between Māori ancestors and their living descendants. However, while the exhibition approached these themes from a cultural point of view, the political dimension remained hard to understand, according to the different reactions of the public which I observed.

As has been noted, the collaboration between the two museums suggests that the control of activities around the care of/for objects, their conservation and their display remained mainly 
under the supervision of the New Zealand museum. This impression is confirmed by a comparative study of the reception of this exhibition in Paris and Quebec.

In Paris as in Quebec, this type of control by a foreign institution was a first. The two museums are more in the habit of adapting exhibitions from elsewhere by adding objects from their own collections, by reviewing certain sections for specific audiences or by rewriting some of the texts. In the case of the E Tū Ake exhibition, the Musée du quai Branly only added an introductory panel presenting the Te Papa museum, a map of the country, as well as a tactile device accompanied by texts in Braille and large characters - all this with the backing of the designer museum in Wellington. (Gagné \& Roustan 2014, 84)

Te Papa policy on its collections also tells us about the community's attention to their material histories, but it seems the sacred dimension of these objects and the respect for the links between objects and living beings was understood by the public.

As a counterpoint, the MQB-JC had considerable technical resources, which allowed them to practise a different kind of museology, such as allowing for more space and the support material for the explanatory panels. The PR and communications campaign, via the MQB-JC, mobilised a number of advertising media. Numerous posters were displayed in the most visited districts of Paris, as well as in train and bus stations while the museum and the RATP (public transport company of Paris) jointly promoted the event in the streets and metro stations. A haka was even the subject of a flash mob in one of the busiest metro stations, Saint Lazare.

To conclude, this exhibition, the first example of collaboration between antipodean and French museums, was a real success despite professional differences and intercultural ambiguities. This temporary exhibition was notably the most visited of the Parisian museum in 2011. For Te Papa, it was an opportunity to send the collections to France and to try to raise awareness of an audience lacking prior contact with traditional or contemporary Māori culture. For the MQB-JC, this exhibition enabled staff to increase their knowledge of the taonga kept in their collections, and provided the opportunity to envisage future collaborations with South Pacific institutions such as Te Papa or the cultural centre Tjibaou in Noumea (New Caledonia). It also led to a better understanding of the reasons which lead to requests for the repatriation of human remains. The exhibition Mäori: Their treasures have a soul and the 
repatriation of Toi moko have, in my opinion, been supported by a change in the points of view of French institutions on the place of human remains in museum collections and have also contributed to the evolution of sensitivities on the presentation of 'the Other'. They also seem to have led to new research on ethnographic collections, as I show below.

\subsubsection{Other collaboration post-repatriation}

\subsubsection{Tattooists: Tattooed at MQB-JC 2015}

This exhibition, which was on display from 6 May, 2014 to 18 October, 2015, is not directly associated with the repatriation of Toi moko that occurred two years before at the MQB-JC. The only association observed could be my personal involvement in the creation of the exhibition. My involvement happened thanks to the experience gained in New Zealand through the repatriation process. Presenting the practice of tattooing in separate times and places, the exhibition combined the heritage of the tattoo practice and works made by contemporary practitioners from all around the world. An area of the exhibition was dedicated to tā moko. The scientific commission of the exhibition, led by Sebastien Galliot (an anthropologist who has focused his research on tatau, Samoan tattooing practice) asked me to take charge of finding two Māori artists to represent the practice of tā moko through their art. The intention of this project was to find a tattoo expert and their student in order to exhibit their art pieces in the exhibition and tell their stories. The commission also asked me to write a chapter about tā moko and pakipaki māhunga for the exhibition catalogue. Some participants also had the chance to meet and present their work during a conference organised at the Institut National d'Histoire de l'Art (INHA) in Paris on 26 and 27 September, 2013.

I decided to contact Taryn Beri from Ngāti Toarangatira, who tattooed two of my friends and colleagues during my internship at Te Papa in 2012. I made this choice in order to demonstrate the role of women in the practice of tā moko. I had had the chance to meet her several times in Wellington and I knew that she had been taught by the same tohunga tā moko (expert) as Hohua Mohi, the tattooist who did my own kirituhi (tattoo on foreign skin). The tohunga tā moko is Mark Kopua and both he and Taryn were interested in being part of this major international exhibition on tattoo practice.

The project took nearly two years to complete (Galliot, pers. Comm) and the exhibition commissioners asked for specific artistic forms for this event. The MQB-JC sent silicone mouldings of human body parts to be tattooed by each of the expert artists. Taryn Beri had to create an art work drawn on canvas. Both art works were displayed in the section dedicated to 
tā moko associated with ancient taonga such as carvings or uhi but also modern tattoo machines. They were all displayed beside explanatory panels about the transmission of knowledge that defines the practice of tā moko today.

Thanks to my experience in New Zealand, I had the chance to work on a project that was separate from human remains. It was a great opportunity to become the liaison between French museums and Māori artists. My involvement in this project was not to convey Māori knowledge, but to contribute to the appropriate information being shared with international audience by enabling Māori experts, tattooists, to talk about their profession and what it means.

\subsubsection{Pacifique(s) Contemporain Rouen and Le Havre November-December 2015}

Pacifique (s) Contemporain was the first edition of an art festival inviting artists from the Pacific to come to Normandy as artists-in-residence. During this period, artists exhibited their art forms, in groups or alone, in several key places located both in Rouen and Le Havre such as; university libraries, natural history museums and art galleries, and to finally lead workshops at the regional art school Ecole Supérieure d'Art et Design Le Havre-Rouen (ESADHAR). The main objective of the festival was/is to demonstrate the richness of artistic expression by inviting established and emerging artists to demonstrate their different perspectives on contemporary Pacific arts. The artists were of different origins but predominantly lived in New Zealand. Dr. Jacqueline Charles-Rault (director of the cultural service at the University of Le Havre) and Dr. Caroline Vercoe (professor at the University of Auckland) created the festival. They invited 14 different artists: Janet Lilo, Tracey Tawhiao, Ane Tonga, Edith Amituanai, Natalie Robertson, Rachael Rakena, Angela Tiatia, Shannon Te Ao, Lisa Reihana, Michel Tuffery, George Nuku, Jeremy Leatinu'u, Greg Semu and Robert George to share their insights about Pacific arts, as contemporary Pacific people, with the French public.

The city of Rouen played a role in this festival by reflecting the repatriation project that occurred three years before. This festival was a perfect opportunity to reaffirm the relationships established by politicians and former repatriation practitioners. The permanent exhibition in the Museum of Rouen opened in 2011, the temporary exhibition by George Nuku, Bottled Ocean 2115 ran from April 2015 to January 2016, and this festival was held at the end of 2015, confirming the long-term relationship that politicians, the museum director and the media were relaying. This collaboration was also an opportunity to understand current 
ideas on repatriation and Pacific cultures from artistic viewpoints through videos by Lisa Reihana about the wāhine imagery built and shaped by Europeans, and the video by Michel Tuffery about James Cook's circumnavigations. The Portique (contemporary art space in Le Havre) welcomed Natalie Robertson, Rachael Rakena and Robert George, whose works focused on fishing practices, the Pacific Ocean, marine pollution and the extinction of species.

This festival was also an opportunity to present different research and collaborations between artists and researchers during an international colloquium held in Le Havre between 4 November to 6 November 2015. For three days, artists, researchers and museum professionals were able to present their work and discuss current challenges and themes presented by the festival. Sebastien Minchin, George Nuku and I presented papers on the process of repatriation. Minchin focused on the relationship between Rouen and Te Papa, Nuku spoke about his personal thoughts on future possibilities that such projects could engender and I presented my experience at Te Papa, the research I conducted for KARP and the repatriation ceremonies I participated in while in New Zealand.

The festival was not focused on human remains, their meaning for communities of origin or even their place in a museum. The festival was actually an opportunity for the artists themselves to introduce contemporary art from the Pacific, and for museums and cultural institutions to meet several artists with whom they could maintain long-term relationships in order to get a better understanding of the imagery and uses of the art of their cultures and its misrepresentation by previous European writers and explorers.

\subsubsection{Océanie at MQB-JC in 2019}

Océanie, the French version of Oceania from the Royal Academy in London, was staged at MQB-JC from 12 March to 7 July 2019. This was the first time that a French museum had been part of such a large-scale collaboration to show Pacific artefacts preserved in different museums from European cities (such as Cambridge and London in the United Kingdom, Munich and Leipzig in Germany, and Paris in France) as well as from Wellington and Auckland in New Zealand. In many ways, Océanie could be seen as the culmination of the last decade of Indigenous art exhibitions at the MQB-JC, and could also be considered the continuation of a new approach to international museum collaboration.

For instance, the MQB-JC had already worked closely with Te Papa during the reception of Màori: Leurs trésors ont une âme (E Tü Ake: Māori Standing Strong) in 
2013 and La pierre sacrée des Māori (Kura Pounamu) in 2017. Even my own involvement in the exhibitions E Tu Ake and Tatoueurs tatoués from 2014 to 2015 were the result of the repatriation programme and the creation of new relationships with Māori museum professionals and artists. In my opinion, the return of Toi moko clearly redefined the nature of the relationship between the MQB-JC and Te Papa. As for other European ethnographic museums grappling with their colonial legacy, these relationships provided a powerful new form of cultural dialogue that is reshaping international policy as demonstrated in exhibitions such as Océanie. From the MQB-JC's perspective, it seemed logical to work with other institutions from Europe and Polynesia in order to assemble the most important exhibition of this kind yet seen in Europe in terms of the number of objects presented.

In London, the exhibition was visited by over 135,000 people, including some 5,000 admitted free with passports from Pacific Islands nations and territories (the Paris version of the exhibition attracted about another 125,000). The conferences of two major subject associations, the Pacific History Association and the European Society for Oceanists, were among events that brought about 1,200 participants to linked academic programs, including students, scholars, curators, and artists from about 20 Pacific countries. Livestream and video programs, including a number of interviews with individual Islander artists, received over 250,000 views; the catalogue sold over 10,000 copies in English and about 4,000 in French. (Thomas 2019, 270)

Every time I go to the MQB-JC to visit a temporary exhibition located on the ground floor, I admire the entrance area with the title written on a long wall that you can see from the garden outside the building. It shows the key role of temporary exhibitions in this dynamic museum with the use of such a large space for many kinds of scenography. This exhibition space consequently encourages the public to move freely through the generously-spaced objects in the show, to look around them, and to look closely at them. According to some of my French colleagues, this exhibition was quite impressive in terms of the objects presented and the scenography, the way in which they were displayed, but maybe the presentation was overly encyclopaedic in approach. Of course, Océanie was created by academics and curators, and we can clearly see the differences in approach in the label texts compared to the everyday way in which these things are discussed in the Pacific. This point was actually debated at the last Museums Aotearoa Conference in May 2019. 
This exhibition was divided into seven different sections (Travels; Anchorage and Community; Gods and Ancestors; Living Arts and Ceremonies; Culture of Giving; Meetings and Hybridisations; Memories and Modern Challenges). Those sections were chosen in order to present the links between all the islands in the Pacific represented, but it also helped the public to generalise all Pacific communities. In France, we learned at school that the world is divided into five different continents including Oceania. In French museums, we continue to homogenise all of the many Pacific communities and allow the French public to understand the common points more than the differences between all those communities.

\subsubsection{Senators arrival in Wellington, 28 September 2018}

The Minister of Foreign Affairs from Paris invited me to present my research during a senatorial visit to New Zealand that occurred from 27 to 29 September 2018. The ministry also contacted Te Papa authorities in order to organise a meeting between repatriation practitioners and the senators. Te Herekiekie Herewini and Arapata Hakiwai were thus in charge of organising their visit to TE PAPA. At this occasion, we could share the work undertaken by KARP and my paper in order to give the French diplomatic delegation a picture of the different research led by France and New Zealand. Politicians had an important role in the success of the project and the arrival of a new delegation demonstrated the diplomatic interest maintained by the French senate towards Māori culture and communities and, particularly, Te Papa. The delegation comprised Eric Jeanseannetas (vice-président of the France-New Zealand friendship group and senator of the department Creuse), Annick Billon (senator of the department Vendée), Jérôme Bascher (senator of the department Oise) and Nathalie Tilliole (senior officer, Division of Interparliamentary Cooperation Actions and Interparliamentary Assemblies).

I met the senatorial delegation at the Intercontinental hotel on the morning of Friday 28 September 2018. The senators and a French embassy team, led by the Ambassador Sylvaine Carta-Le Vert, were present also. During our breakfast, the senators asked me questions about the traffic of Toi moko during the $19^{\text {th }}$ century, their acquisition by French museums, key dates in the history of New Zealand and its national identity, such as the date of the Treaty of Waitangi, 6 February 1840, and the date at which New Zealand women gained the right to vote, 19 September 1893. They were naturally also focused on the current repatriation practice in New Zealand. Additionally, they wanted to know more about the mihi whakatau 
and other protocols of welcome that would occur in the next hour at Te Papa. The last part was quite a concern for the senators, who did not want to be offensive but wanted to be respectful towards Māori tikanga. This meeting was consequently intense in terms of the interest shown through the number of questions asked, coupled with their unfamiliarity with New Zealand cultural identity.

After breakfast, two cars were waiting for us in front of the hotel and drove us to the entrance of Te Papa. Here, the museum staff welcomed us with a hongi and invited us to go to the red couch room located on Level 3. We proceeded to the mihi whakatau, and the French delegation, as the manuhiri, were represented by the Ambassador, the senator Jerome Basher and me. After the speeches, we decided to sing a waiata in Māori in order to acknowledge the tangata whenua. This ceremony was the first experience of Māori tikanga for all the French government representatives including the Ambassador. Sylvaine Carta-Le Vert had taken up her post in New Zealand only 20 days before. A quick cup of tea was shared before the presentations began. Each speaker had 15 minutes and, according to the programme, four participants were expected to discuss topics linked to the repatriation. Te Herekiekie Herewini talked about Te Papa and its biculturalism, Amber Aranui shared the research that was undertaken by KARP, Derek Lardelli explained how the analyses of facial tattoos on each tūpuna helped to understand the global artistic practice of tā moko and I spoke about provenance research in French archives and the possible future repatriation operation. We were rapidly running out of time and the organisers decided to have a break between Derek Lardelli's speech and my presentation. Instead, they switched my presentation with the tours of both the Gallipoli and Rongowhakaata exhibitions that initially should have happened just before lunch. The senators did not find the Gallipoli exhibition very relevant and I tried to remove the tour from the daily programme, but in vain. This decision meant that my talk had to take place during lunch and my disappointment was immense. I had to present my research while Te Papa's staff and the French senatorial delegation were sharing food, not an ideal outcome.

However, despite this, the diplomatic visit was meaningful in terms of the delegation's interest in understanding Maori tikanga and New Zealand generally, and their readiness to learn and keen observation of everything that happened. Based on this experience, it is clear to me that there are not only museum activities such as exhibitions (permanent or temporary) or cultural festivals that may be defined as post-repatriation collaboration, but also diplomatic visits play a role played as well. 


\section{Conclusion}

The research presented in this chapter has revealed the complex debates which led to rethinking the role of human remains in French museums. French professionals had to confront these tricky issues to figure out the place of human remains in museums and how international perspectives can help to get a better understanding of the museums' stakes in global relationships in terms of Indigenous human remains and contested items collected during the colonial period. Since the failed Rouen ceremony in 2007, museums were more able to discuss and develop their responses in line with international perspectives. That is why, I have argued, conferences and seminars organised at MQB-JC in 2008 or at MNHN in 2010 have been decisive in clarifying the status of human remains in museums and improving the possibilities for successful repatriation. My direct participation in the negotiations, as documented in the field work conducted for this thesis, helped me to critically analyse the evolution of the debates: from an isolated event, the failed ceremony, to a longer discussion on repatriation policy and the eventual creation of a specific law for the return of Toi moko to New Zealand.

At the beginning of the process in 2007, as previously discussed, French museums had only returned the bodies of Saartje Baartman to South Africa and Vaimaca Peru to Uruguay, both in 2002. This early experience of the repatriation of human remains did not appear sufficient to enable the French side to respond quickly and effectively to KARP's approach. French authorities needed to shape their own understanding of international repatriation challenges through the course of meetings and scientific symposiums such as that at MQB-JC in February 2008, when Te Papa representatives had the opportunity to meet directors and professionals from Parisian museums. This was consequently an occasion to start new dialogues between museum professionals. Occasions such as this have been key to the overall process of negotiation. In an attempt to get a better mutual understanding, the ceremonies appeared the best occasion to introduce Māori values and invite French delegations to be part of the process leading up to the deposit of Toi moko in the wāhi tapu at Te Papa.

These interactions were also an opportunity to think about how Western principles were applied inside a public place and the ways that the European tradition of secularism was challenged by Indigenous spiritual practices. Māori repatriation ceremonies employ tikanga that might be considered to be religious dogma from the sceptical French secularist 
perspective. However I prefer to see them as spiritual learning with freedom of interpretation according to iwi, whānau, and individual understanding. Every Māori present at ceremonies has his or her own affiliation and perspectives towards human remains or his or her own application of tikanga like whakapapa and tino rangatiratanga. Making this point was be essential in order for French museums to understand the diversity of Māori cultural identities. The invitation to organise Māori ceremonies in French institutions led to different debates but also confirmed the application of the French principle of freedom of expression and echoed the national motto "liberty, equality, fraternity".

This desire to increase awareness of Indigenous identity has been recognised also in the creation of several cultural projects in France, as I have described above. I consider those collaborations to be the direct result of repatriation. The dialogue undertaken for the return of human remains was, therefore, also an opportunity to let Māori museum professionals speak and act as the intermediaries between the public and iwi. Repatriation researchers, Māori management and kaitiaki all played an important role in French museums by presenting taonga according to Māori tikanga. So I return to the research question: Can the repatriation process be considered a museum practice? As we have seen in the last two chapters, despite the continuing disparities in museum organisation in France and New Zealand there has been some progress and a shift to shared and mutual strategies through the practice of repatriation. Having presented in the last four chapters a range of varied data gathered on the topic under examination, I now turn in chapter Five to a cross-case analysis and discussion of the historical, ethnographic and documentary findings presented. The next chapter will focus on the overall themes that emerge from the research leading to arguments that address the research questions above. As we will see, the findings are varied, complex and interdisciplinary and throw light on the inter-relationships between museums, and adjacent diplomatic, political and cultural spheres, which have to be taken into account in order to accomplish the return of Toi moko. 
Table 4: List of post-repatriation projects in France since 2011.

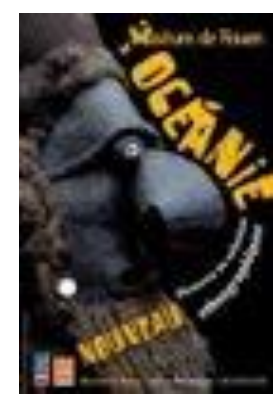

2011: Océanie permanent exhibition at the Natural History Museum of Rouen

2012: Māori : leurs trésors ont une âme exhibition in MQB

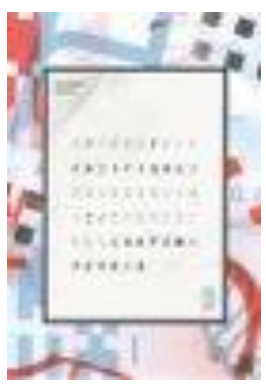

2015: Pacifique(s) Contemporain Art Festival in Rouen and Le Havre

2015: Bottled Ocean 2115 exhibition by George Nuku at Rouen

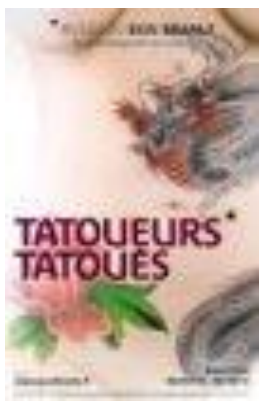

2016: Tatoueurs Tatoués exhibition in MQB-JC

2017: Pounamu exhibition in MQB-JC
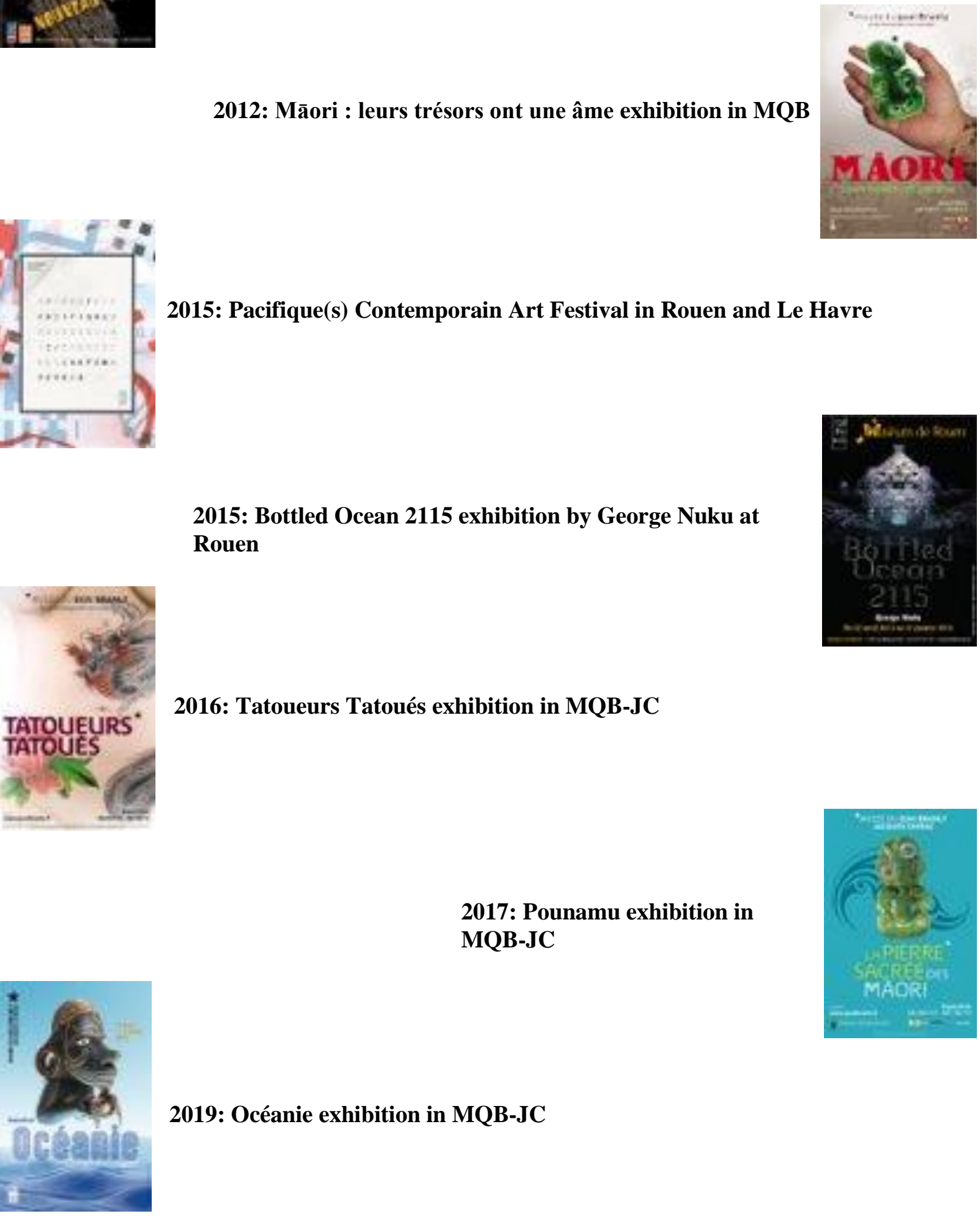

2019: Océanie exhibition in MQB-JC 


\section{Chapter Five}

\section{Repatriation as museum practice:}

\section{"...everything is going well as long as there is no conflict".}

\section{Introduction}

The quote used above as a chapter title is taken from my interview with Michel Van Praët, who is emeritus professor at MNHN. He used this expression when he referred to the complexity of working with human remains in the museum environment. He was talking about the difficulty of preserving Toi moko when there are so many controversies in terms of preservation protocols and such a high level of discussion and debate. I think this quote reflects my approach when I started to work on this final chapter.

This thesis has considered the impact of the repatriation of human remains on museums in France and New Zealand. In the last chapter, I studied the emerging practice of repatriation of human remains in French museums and the experience of professionals in dealing with Māori tūpuna. My research has suggested that the engagement of local museums in the negotiations, and the way in which they engaged with KARP and its policies, and found out more about repatriation practice in New Zealand, helped French authorities to make positive decisions. The organisation of ceremonies, firstly, but also, secondly, various post-repatriation projects such as exhibitions, were highlights of the process which created mutual spaces for dialogue and discussion about the issues from both French and New Zealand perspectives. Repatriation was therefore a project focused on the past primarily as a means of reconciliation in the present, but quickly became something more, a significant new development in museum practice within the overall collaboration between French and Māori researchers and museum professionals.

In this chapter, I review, analyse and discuss the ethnographic fieldwork conducted in this study, which included events, discussions and interactions that I saw, heard or contributed to throughout my personal involvement in the repatriation process. The way the repatriation has been conducted between New Zealand and France, as explained in chapters Three and 
Four, has created a new role for museums in the post-colonial period. As shown in the research design (Introduction), I decided to complete the data analysis through a thematic approach that enabled me to encompass several issues heard and/or observed since the beginning of the negotiations by the museum professionals involved in repatriation. As suggested by Yin (2002), I felt a cross-case analysis was the appropriate method. I employ it here to demonstrate the evolution and progress of this engagement between Māori people and French museum professionals. This method also allows me to reflect on the concerns, differences, and similarities across the cases. Interviews presented in the previous two chapters are analysed here in order to obtain an explicit understanding of the process and how it shaped the attitudes of the professionals involved. How have museums changed their practice through the repatriation? Can repatriation be thought of as a legitimate museum practice today?

Attempting to understand the repatriation process as a museum practice in a post-colonial context, I decided to break the analysis and discussion into six different themes which are presented in the first section of this chapter: evolution of names; repatriation from theory into practice; repatriation as a system of interaction; ethics and dignity of human remains; a method of (re)connecting; and cultural diplomacy and repatriation. These themes, which emerged from the analysis of the data, enabled me to assess the complex mix of professional attitudes towards such a complex process. By examining the evidence through these themes early on in the research analysis, I was able to draw a comparison between museum repatriation practices in France and in New Zealand. The discussion of the themes in this chapter addresses my research question and reinforces my attempts to develop a comprehensive synopsis of repatriation for the museum field. In the following discussion I suggest that thinking of repatriation as a practice of reconciliation in global international relationships, and more specifically as a means to transform the imbalance of power between Western museums and Indigenous communities, gives this thesis a particular and relevant focus in these times of reconciliation, racism and reckoning with decolonisation. 


\subsection{Analysis and discussion}

\subsubsection{The historical analysis}

The historical analysis of the acquisition of human remains by French institutions, laid out in the Chapters One and Two, played a key role in the analysis as soon as I examined the negotiations between French and New Zealand authorities which happened in recent years. This research strategy contextualised the case study of the repatriation process so as to understand the nature of the request made by the KARP and the debates that ensued in the French cultural environment. The historical sources I examined enabled me to construct a narrative which not only explained the changes in the trade of Toi moko in the global colonial strategy, but also provided a framework for understanding the interests of the ships' crews in obtaining them and the growing collecting zeal in French public institutions such as museums and universities. The observations of Toi moko acquisitions by French explorers analysed in Chapter One and Two gave us more clues to the frequency of explorers taking Māori ancestors offshore.

This study also related the exact sites where explorers were trading with local tribes and gave, consequently, more information about the ancestors themselves. Knowing where the trade the occurred helped the understanding of the importance of the trade and the journey of the ancestor before being considered as French property. For example, the Thétis acquired a Toi moko before arriving in Aotearoa. Busseuil, the surgeon and naturalist, acquired one head probably at Paramatta, in the Sydney region, where he and Bougainville met Samuel Marsden who told them a lot about Māori communities (Bougainville 1837). On this occasion, Bougainville wrote that they had the chance to meet whalers that came from New Zealand with heads aboard (Bougainville 1837, 524). Also, the Uranie stayed five weeks at Port Jackson where the captain may have acquired several Toi moko between November and December 1819 (de Freycinet 1837, 909). The involvement of French explorers in a trade that involved Māori human remains in Australia gave us more clues to the popularity of such bargaining. This research also conveyed information about the motivations of the French to obtain such treasures.

The analysis of this historical data clarified the value of such sensitive collections in the overall strategy of museum classification according to Western stereotypes and conditions. As Michelle Horwood has argued: 
Public museums were instrumental in this process [of categorisation]. They provided the collection, the enthusiasm and expertise whereby material representations of culture could be assessed, and placed within the schema of cultural evolution and interrelatedness. (Horwood 2015, 135)

Influenced by the first written testimonies made by European explorers, museums repeated, relayed and reinforced these statements and assumptions based on the colour of skin, cultural differences and colonial aspirations. In his vade-mecum, Michel Van Praët argues that an awareness of the historical context of acquisition is essential in understanding the global story of each set of human remains located in French public collections (Van Praët 2019, 12). This thesis has therefore shown the evolution of the interest and fascination of French museums professionals in terms of the history and context of the acquisition of human remains. At the time of the acquisition, only a few aspects of French attitudes were noted in acquisition documents and these are mostly French-centric. Only the names of donors and the dates of acquisition appear. Names of the deceased or their tribal affiliation were not considered essential because of the condescending attitudes held towards the inhabitants of the South Pacific.

I have tried to examine throughout this study the entire journey of Toi moko from their source and how they made their way into different French public collections, basing my analysis on archival data from journals of circumnavigation, museum archives and authors (Dunmore 1991; Tremewan 1990; Poirier 2003; Sinsoilliez 2005; Proust de la Gironière 2002). This material shows the involvement of the French colonial empire in the territorial invasion of Aotearoa which occurred in the first half of the $19^{\text {th }}$ century. I have contextualised these sources with work by English and New Zealand authors from the end of the $19^{\text {th }}$ century (Manning 1863; Robley 2003; Best 1903, 1904) and today (King 1972; Te Awekotuku 2007; Aranui 2011, 2018; Mead 2003) to provide more insight into the process of pakipaki māhunga and the art of tā moko. The transmission of such intangible Indigenous heritage shows the continuing strength of Māori society whereas European scientists were convinced about their disappearance at the end of the $19^{\text {th }}$ century. 
Table 5: French cities and institutions that returned Toi moko:

\begin{tabular}{|c|c|c|}
\hline City of Location & Institutions & $\begin{array}{l}\text { Number of Toi moko and date of } \\
\text { acquisition }\end{array}$ \\
\hline Rouen & Natural History Museum & - $\quad 1$ in 1875 (Drouet) \\
\hline Paris & Natural History Museum & $\begin{array}{l}-1 \text { in } 1820 \text { (de Freycinet) } \\
-\quad 1 \text { in } 1864 \text { (Maxime du Camp) } \\
-\quad 2 \text { unknown date or donor. }\end{array}$ \\
\hline Paris & Quai Branly & $\begin{array}{ll}- & 2 \text { in } 1885 \text { (Anonymous donor) } \\
- & 1 \text { in } 1886 \text { (Le Printemps) } \\
- & 1 \text { in } 1929 \text { (Louis Capitan) } \\
- & 2 \text { in } 1947 \text { (Adrien Paris) } \\
- & 1 \text { in } 1999 \text { (Germaine Urbain) }\end{array}$ \\
\hline Paris & Maritime Museum & $\begin{array}{l}\text { - } 1 \text { unknown date (from Lesson?) given } \\
\text { through Rochefort natural history } \\
\text { cabinet. Unknown date of transfer } \\
\text { between Rochefort and the Maritime } \\
\text { museum. }\end{array}$ \\
\hline Nantes & Natural History Museum & $\begin{array}{l}\text { - } 1 \text { in } 1826 \text { (François Louis Busseil) and } \\
\text { acquired aboard the Thétis). }\end{array}$ \\
\hline Sens & Local Museum & $\begin{array}{l}\text { - } 1 \text { in } 1844 \text { (Alfred Lorne, collector from } \\
\text { Sens- acquired during Astrolabe } \\
\text { expedition in 1827? ) }\end{array}$ \\
\hline Lille & Fine Arts Museum & $\begin{array}{l}\text { - } 1 \text { in } 1850 ? \text { Probably donated by } \\
\text { Alphonse Moillet. }\end{array}$ \\
\hline Dunkerque & Natural History Museum & - 1 in 1841 (Duhamel) \\
\hline Marseille & $\begin{array}{l}\text { Ethnographic museum } \\
\text { (MAAOA) }\end{array}$ & - $\quad 1$ in 1989 (Henri Gastaut). \\
\hline Lyon & Musée des Confluences & - $\quad 2$ (unknown dates and donors). \\
\hline
\end{tabular}




\begin{tabular}{|lll|}
\hline Montpellier & $\begin{array}{l}\text { Conservatoire } \\
\text { d'Anatomie }\end{array}$ & -1 in 1854 (Joseph Marie Dubreuil). \\
\hline
\end{tabular}

The chart here summarises my research into where Māori human remains have been located in French collections. To date 21 Toi moko have been repatriated from nine different cities throughout the country, eight museums and one University (Montpellier). Four Museums are natural history museums, one fine arts museum and one maritime museum, the three others are ethnographic museums (Musée des Confluences, MAAOA and MQB-JC). Twelve Toi moko were located in Parisian museums which demonstrates the cultural focus of the museums in the French capital. The purpose of the chart is also to demonstrate the involvement of museums throughout the entire country and not only Parisian museums. Even though the majority of Toi moko were preserved in Paris (11), other museums wanted to participate and have an active role in the process.

\section{Map 3: Map of France with locations of cities where institutions returned Toi moko between 2011-2012 (cartesdefrance.fr, accessed 2 December 2010).}

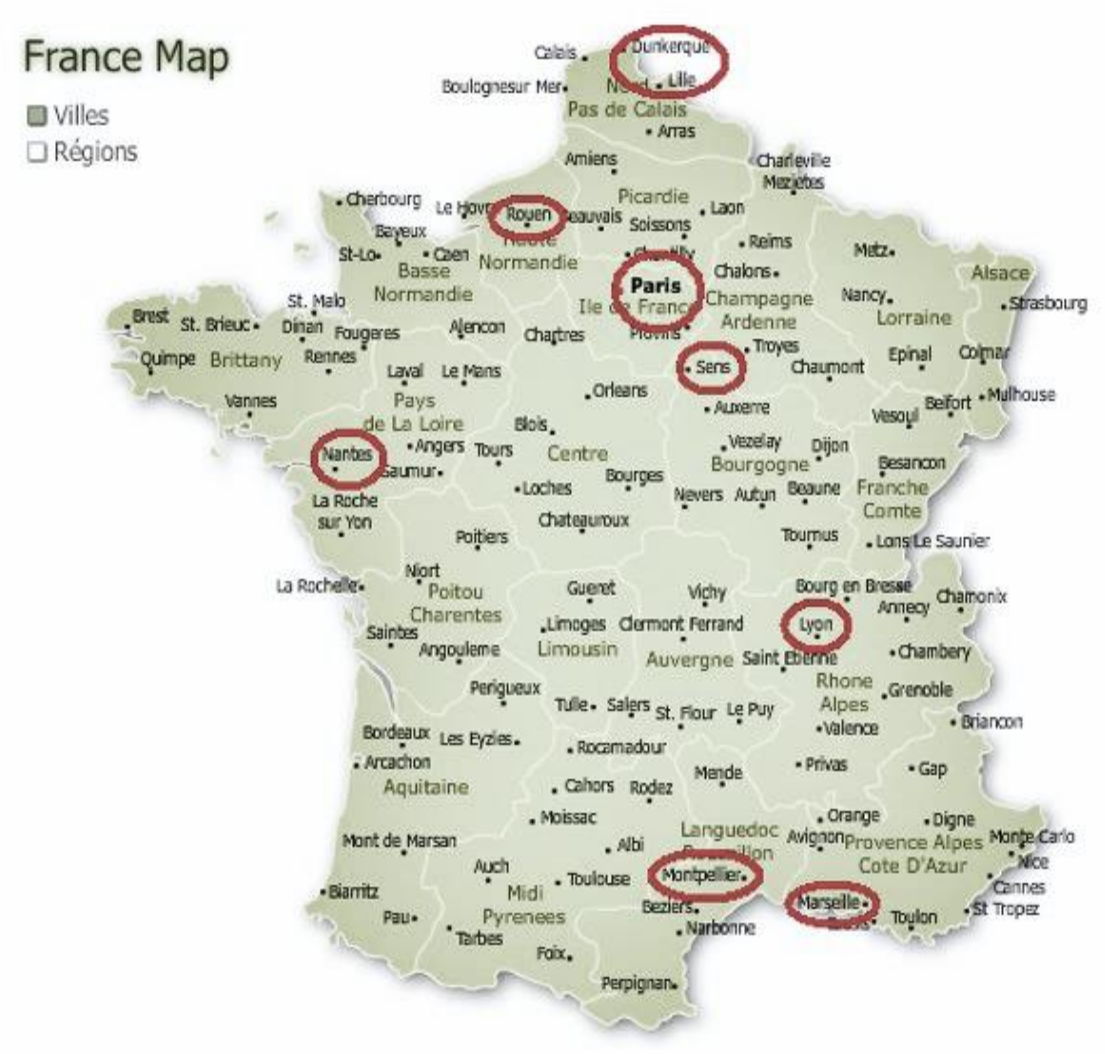


That is why the Museum of Rouen wanted to use the opportunity of the repatriation to obtain media coverage and better publicity. This chart also reflects the diverse categories of museums involved and the balance of power between national and local museums. Te Papa wanted to work with the Museum of Rouen because it is the first museum that confirmed its approval for returning Toi moko. On the other hand, working alongside the MQB-JC gave Te Papa the opportunity to work with a well-known national museum with a bigger influence in France and also in Europe. As we have seen over the past few years, Germany returned Toi moko and Belgium is creating a national catalogue of human remains in order to provide better answers in case of demands for returns, and also to get a better understanding of its anthropological collections. The MQB-JC is not considered here as the key factor that convinced other countries to take part in such operations but I think it represents the broader context of progress in the repatriation debate and its improved outcomes because of the international recognition of the Parisian museums.

\subsubsection{Thematic analysis}

During two different internships in 2009 and 2012 at KARP, as described in Chapter Three, I had the chance to develop my understanding of repatriation policy in New Zealand. This time spent at TP was also an occasion to answer some questions asked by French repatriation participants. Those questions helped me to frame my thematic approach to analysing the repatriation process and gave me the opportunity to answer most of the questions raised during the negotiation period and even in post-repatriation ceremonies. I finally selected six different themes which emerged from the data that suggest the repatriation process can be understood as a professional practice and also demonstrate the ways in which museums are playing a role in establishing and maintaining international relationships.

\subsubsection{Evolution of names}

Evolution of names describes the continuous changes in appreciation of Toi moko evident in the different terms given to them over time. Through different time periods and from disparate perspectives, Māori heads have been named and valued differently according to their observers and their historical perspectives. 
Table 6: Naming and categorisation of Toi moko through the years

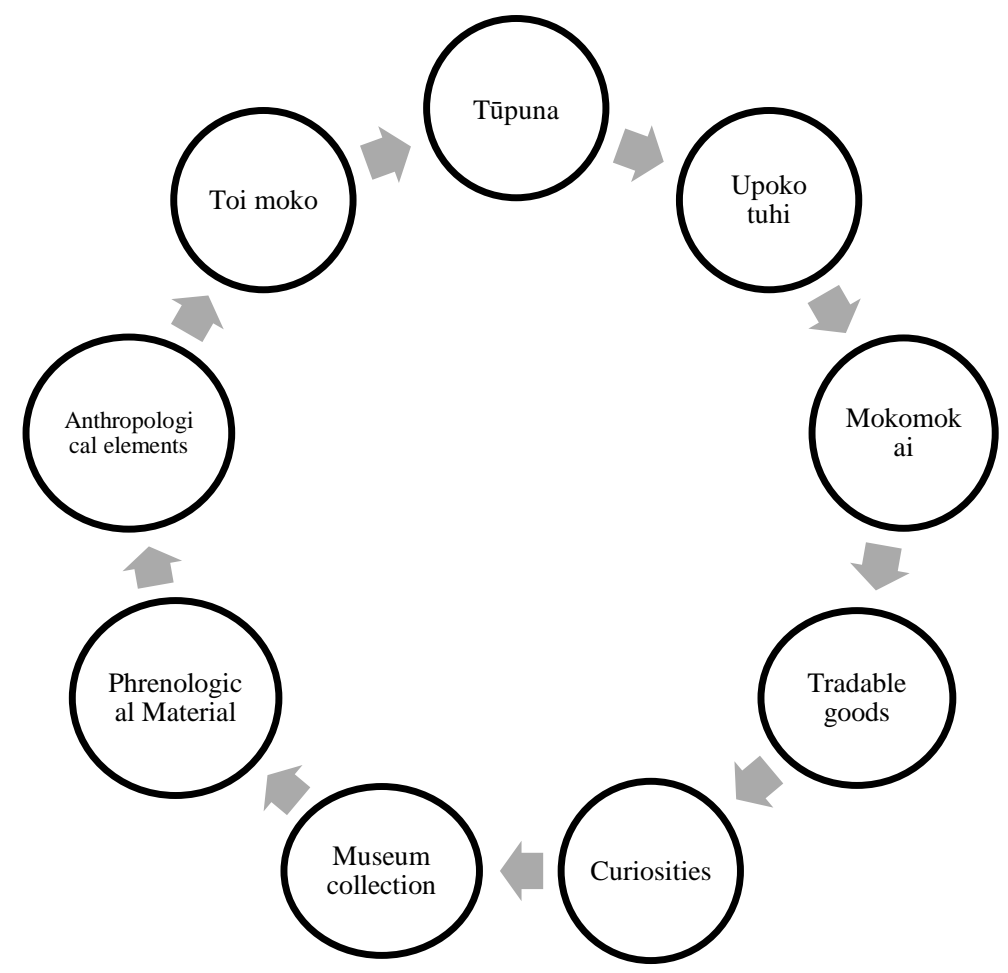

They were tūpuna first and foremost but also used as tradable goods. Their acquisition by foreigners placed Māori ancestors in another context. Formerly considered ancestors, they have been placed under the judgement of Westerners. They were no longer ancestors, but traded objects only used to categorise human races from savage to civilised within Western scientific and museological discourse. Explorers and scientists of the $19^{\text {th }}$ century used the Māori word 'moko mokai' (Lesson 1829, 119; Durville 1830, 209) in their texts in order to describe such human heads. Domeny de Rienzi also attempted to describe the word 'mokomokai' by defining 'moko' as "tattooed head" and 'mokai' as "miserable” (Domeny de Rienzy 1838, 180). In French, the term 'mokomokai' may also have been used to diminish the process of pakipaki māhunga as a barbaric process since its appearance in the first references (Lesson 1829; Dumont d’Urville 1830; Bougauinville 1837).

As I explained in Chapter Two, 'mokai' is a term used to define slaves or captives. That is the reason 'upoko tuhi' may appear as a general term that defines all heads preserved under the drying process and not only those of slaves or captives. Acquired by museums, heads of tūpuna comprised scientific collections and were specially categorised in phrenological/anthropological collections. Today, according to KARP, the term 'Toi moko' is 
more appropriate for describing ancestral remains. Used for the first time by Māui Pōmare, this term commemorates his work in the repatriation field in New Zealand (see chapter 3).

Once European museums and scientific institutions had acquired them, they labelled Māori human remains according to their own codes. Human remains were thereby introduced as curiosities and phrenological material before being hidden in museum collections where they were considered anthropological artefacts according to Western scientific beliefs. This categorisation has been in place since the $19^{\text {th }}$ century, as shown in chapters One and Two, to prove the so-called universal dimension of French museums. Thanks to the return of human remains to New Zealand, French museum professionals have acknowledged the primary definition of Toi moko as ancestors and had to recognise their genealogical affiliations with living, contemporary Māori communities. However, several questions remain both in France and New Zealand about the name commonly used in te reo to describe these human heads today. Are we talking about mokamokai or Toi moko? This question illustrates the rich, diverse and changing perspectives that define the journey of Toi moko.

The views of Toi moko have been influenced by the European image of exotic curiosities, but the fact that not only chiefs or warriors but also captives, and women and children had their heads dried according to this process has led to debate and arguments against repatriation. Several participants in the debates said that the social origins of ancestral remains should be a key factor in the decision to return them or not. Here again, European values and codes have been applied in the definition of 'captives' in Māori society and this influenced the Western popular imagery of Indigenous social positions. All these journeys and changing meanings as seen in the treatment of Māori heads in French collections reflect the controversial position of French museums towards repatriation and, moreover, the place of human remains in collections. Hence the return of Toi moko encompassed several debates, issues, and legal holes in French museums' etymological definitions in present days.

\subsubsection{Repatriation: From theory to practice}

The repatriation of human remains is a new process in museum history and, furthermore, the return of ancestors can be considered today as an important new aspect of museum practice in its own right. As the literature review in the Introduction to this thesis demonstrates, there has been much research on the history, theory and legal debates concerning human remains but not so much about the actual practice of repatriation. My research, as shown in the last chapter, addresses this gap by providing a close analysis of what happened in the negotiations 
around returning human remains from French museums to New Zealand, and in doing so, discusses how the understanding and attitudes of the professionals involved changed. For example, Michel Van Praët said during his interview that the museum and cultural professionals did not respond very well to the debate on repatriation before the 2000s (Van Praët, 4min). Museums had acquired Māori human remains from the $19^{\text {th }}$ century until the last acquisition of Toi moko by a museum in Paris in 1999 (see table 4 above). Francophone authors consider the prospect of return as an opportunity for interactions (de l'Estoile 2007; Price 2007; Dias 2007; Alivizatou 2012), and the discussion around repatriation is also mutually acknowledged as part of everyday logistical organisation within museums in France and in New Zealand. As Sharon Macdonald has pointed out, by bringing together "significant 'culture objects'[museums] were readily appropriated as 'national' expressions of identity" $(2003,3)$.

Furthermore, as I showed in Chapter Four, Sebastien Minchin expressed the idea of a museum as a place of debate (Minchin 12'min), echoing Clifford's theory of museums as contact zones (Clifford 1997), so that repatriation is seen as a way to increase understanding between different communities. Despite some professional fears about repatriation, French museums did not participate in or even receive a lot of requests concerning human remains. Before the case of the Toi moko described above, French museums returned the body of Saartje Baartman in April 2002 and the remains of the chief Vaimaca Peru a few months later in July 2002. During the discussion about the Toi moko collection, French participants considered the example of Saartje Baartman as a model because of a few similarities between those two cases. The repatriation of Saartje Baartman mainly showed the respect due and given to living communities of origin by the French government and consequently by the museums. This process of return was, thus, another opportunity on the one hand to increase French awareness about Māori cultural identity and its challenges in the present time, and on the other hand to gain more experience in the procedures of repatriation.

The main difference between the Toi moko and previous cases of repatriation in France lies in the fact that not only one body but an entire collection was requested for return. Furthermore, the identity of each deceased was not known by the French authorities unlike in the two other cases. French politicians wanted to focus on analogies with past procedures in order to deal with the Toi moko situation. Because of the lack of experience in this area, and the fact that there was only one case with a legal decision, it is clear that every case was fundamentally different despite their parallels. There was no repatriation policy in France to deal with the 
requests for repatriation. Every case is examined differently which means that there is an inability to obtain one common guiding principle for such processes. That is why the interaction with Te Papa and the repatriation programme provided enough clarity to the French senators to create a specific law in favour of repatriation. This decision was received by French museum professionals with apprehension. This case would appear to be more a legal procedure than a museum dilemma. The first institutions affected by this were museums but the legal paradox appeared to be an issue of the highest importance in a wider sense. This political intervention was also one of the main differences between the Vaicama Peru and Saartje Baartman cases. Comparatively, the process between the MNHN and the Uruguayan authority was more easily accomplished than the return of Saartje Baartman mostly because contact between the French institution and the local authority was made before the repatriation.

In New Zealand, the repatriation operation illustrates the revitalisation of Māori cultural identity in national cultural policy that has occurred since the 1980s (O'Hara, 6'min). As described in Chapter Three, in terms of museum practice, the influence of Māui Pōmare's accomplishments and the impact of the Te Mãori exhibition led to the creation of the national museum Te Papa in 1998 which welcomed KARP into its midst in 2003. Those unequivocal actions are the result of the transmission of Indigenous heritage and the use of museums to relay such knowledge. Furthermore, the attempt to initiate a bicultural system into the organisation of the national museum demonstrates a political interest in recognising Māori culture as a major component of New Zealand national identity as tangata whenua (Hakiwai, 11 'min). Te Papa is also a window through which international tourists can learn more about Māori tribal identity, thanks to the iwi exhibitions, Māori events on the marae, Māori kaitiaki or professionals, and the relationships with iwi (Schorch 2010, Schubert-McArthur 2014). The analysis of KARP in this research shows the way that it is integrated into everyday operational museum practice. The decision to establish KARP at Te Papa as part of a bicultural programme mandated by government, along with hui ā rohe and other measures, meant that it was part of the museum's institutional framework. This decision thus confirmed to French museums the support of the New Zealand government through the continuous link between Te Papa and local iwi authorities. My participation in KARP's work, as described in this study, was also an opportunity to learn more about the New Zealand plan concerning Indigenous human remains and answer questions asked by French authorities about this 
programme-I was in effect an intermediary or go-between who communicated between the different parties.

In both New Zealand and France, there was a genuine mutual interest in understanding each part of the decision-making process in terms of repatriation. French authorities did not have key experiences of the procedure to apply and New Zealand authorities contextualised their organisations and how they did things. French museums wanted to know more about Māori cultural identity, and Te Papa was able to provide such information. The negotiation was then an opportunity to create relationships with the national museum that may then lead in future to close collaborations with iwi, hapū and whānau. Despite the loss of the object from their museum collection, it seems to me that repatriation practice represented a balance of gains and losses for French museums, reinforcing arguments in the literature about positive benefits resulting from restitution (see for example Arvanitis and Thythacott 2014) and the value of transparency (see Peers and Brown 2003). The repatriation process can thus be considered a museum practice in its own right, alongside other core practices such as collecting, exhibitions, management and policy.

In addition, institutional museum procedures, combined with political efforts at a government level, can clarify the complex situation around repatriation in both countries. This consistent affiliation of cultural with political institutions, such as museums and ministries or museums and senate, reflects this constant synthesis of the cultural and political environments in France. The participation of senators was considered mandatory because French authorities decided to create a specific law to guide the return of Toi moko. By choosing this path, did French authorities include museum professionals in decisions concerning museum collections? The past examples of returns, such as Saartje Baartman and Vaimaca Peru, are compelling cases of different applications of the repatriation process.

In the post-war period, and particularly since the 1970s, and the decolonisation movement initiated after the wars of independence with imperial powers, museums have tended to elevate Indigenous cultural recognition in order to reflect their local communities. The ecomuseum movement and the policy of inclusive museology took roots in this post-colonial period and led to new practices appearing in galleries. In New Zealand the Te Mãori exhibition reflected, and still influences, a way to introduce tribal perspectives by returning control and interpretation of taonga to iwi. Repatriation today is also a means to acknowledge the journeys undertaken by tūpuna and also to frame a new international relationship through 
mutual influences in shared projects that could lead to a common museology as theorised in New Zealand by the WAI 262 for example and internationally by the ICOM Code of Ethics and UNESCO policy on engaging with Indigenous peoples (2018).

\subsubsection{Repatriation as a Strategy of Interaction}

Reflecting the theory of Clifford's "Museums as contact zones" (1997), repatriation can be seen as an opportunity to interact with colleagues from different museums and to work through different points of view. Because repatriation is not only a cultural issue but also part of legal and political debates, most points related to repatriation to Indigenous communities are subjects of interactions and diverse perspectives. One of my informants reflected on this difficulty:

They will use all the elements of the law, experts, and it is unrealistic to think that all the experts and all the specialists of the law will agree. So the debate will continue, we will end up rewriting a law specific to each case!! (Van Praët, 90’min)

The process of negotiation was not only between France and New Zealand. This question of return was widely debated also by repatriation affiliated practitioners in France. Senators decided to pass a new law, but museums were questioning the context of acquisition and scientists were debating the role of human remains in museum storehouses. Also, as we have seen since the beginning of the negotiations, repatriation led to an attempt to construct a single policy on this topic. At this point, however, one unique viewpoint cannot be applied to repatriation in France. The constant oppositions and debates between French repatriation practitioners added to the constant change of opinions concerning each case reflected the unstable process associated with returns.

Moreover, the repatriation of human remains is an occasion to assess different curatorial perspectives towards the use and the place of such collections in museums. For example, the fact that human remains are considered Māori ancestors in New Zealand implies the embodiment of Māori knowledge in museums including a spiritual definition of tūpuna. This statement could be interpreted as challenging the secular dimension of French museums. The repatriation issue is about adaptation and exchange between two groups and their cultural identity, as Nye has pointed out. Because exchanges allow for the chance to better understand the thoughts of others and to see first-hand what values separate nations share, "exchanges are often more effective than mere broadcasting" (Nye 2008, 103). 
The process of return therefore allowed for a new way to see future collaborations between French institutions and Indigenous communities. The repatriation of Toi moko is not only about Māori cultural ceremonies. This whole procedure, including the long and gradual process of negotiation, helped to sustain a new way to communicate and created a new balance of authority in terms of ownership over collections and the authority to consult about exhibition development. Between France and New Zealand, repatriation, therefore, created a new balance of power between Māori and French curators. So consequently, repatriation might appear to be an outcome of the modern inclusive museological approach. This same point can be seen also in the composition of the Māori delegation that travelled to Paris in January 2012. It included curators and collection managers from Te Papa, the repatriation manager, kaumātua, members of RAP and even representatives of Toi Māori. Different delegation members all conveyed strong messages about the strength of Māōi culture and the need to consult them about their culture.

In this study, Toi moko are not only human remains but, through their repatriation, they are agents of a new approach concerning the Western understanding of Indigenous values in museums. Applying Nicolas Thomas' theory which sees an “object as maker of relationships" (Thomas 2016, 19), Toi moko can be seen to encompass an understanding of tikanga not only towards ancestors but also towards all other taonga still preserved in French collections. This new understanding helped the French museums to get closer to Indigenous knowledge and changed their attitudes and approaches to this issue. My observation of the different stages of repatriation (negotiation, ceremony, and post-repatriation projects) demonstrated the mutual interest in interaction and the gaining of information about tikanga and taonga still preserved in French museums. The final decision was not to repatriate all taonga but to let Māori authorities know where their treasures are located and discuss their protection and, sometimes, the possibilities of return.

\subsubsection{Repatriation as a Method of (Re)connecting}

The process of repatriation is also a way to reconnect with history and values. Repatriation is about reconciliation of our present times with a contentious colonial period, and the recognition of Indigenous cultural identity. Repatriation not only focuses on the past but also builds new approaches concerning human remains in museums and connects professionals from different international institutions. The historical research undertaken in my study tries to answer underlying questions asked by repatriation practitioners. In my experience at KARP 
but also with French practitioners, those questions have shaped my effort to contextualise the historical journey of Toi moko as laid out in chapters One and Two. These appeals for more contextualisation and reconnection illustrate the common interest in France and New Zealand to build shared knowledge. Mutual goals and objectives are emerging from this collaborative network benefitting museums and their audiences.

Repatriation also frames the new role of museums in acknowledging Indigenous heritage in the post-colonial period. During his interview, Roger Boulay quoted from an interview with Jean Marie Djibaou in 1984. This citation referred to the purpose of the circulation of collections and repatriation. "An exhibition is dead material," he said. "It is not the object that matters but its reference to life, it is necessary to make an inventory of what existed to support it and create a new identity, all this holds together, for me the cultural is essential, it is what gives flavour to existence" (Djibaou 1984 cited by Boulay 2019, 59'min). To preserve and exhibit collections from overseas, it is important to understand the initial reference given by the group of origin. This study shows that this has successfully happened with Māori treasures in French museums, partly as a result of repatriation work.

The colonial process removed objects from their original context and created an imbalance of power between Western museums and Indigenous identities (something widely criticised in recent debates following Black Lives Matter). For French repatriation practitioners, ceremonies were the occasion to witness the richness of continuous Indigenous cultural heritage in New Zealand, especially when those ceremonies took place in cities (Rouen and Paris) so far away from New Zealand. According to French participants, the two ceremonies held in Rouen and Paris were unique experiences and illustrated the values of partnership and mutual understanding.

Addressing the lack of knowledge in French museums concerning current Māori values, the repatriation process demonstrated that mātauranga Māori was not something frozen in time but was a contemporary application in current New Zealand society. As illustrated by the Toi moko repatriation case studies analysed in this research, Toi moko were not essentially considered as human remains. For French authorities, it was an opportunity to learn more about Indigenous principles and how they were applied inside and outside museums. Toi moko were not just tūpuna but also key elements in a better understanding of te ao Māori globally and the application of mātauranga Māori today. 
In New Zealand, repatriation is a consequence of ongoing and sustainable Indigenous values and identities, but in France repatriation provided a chance to learn about tikanga in its global sense. Repatriation has introduced Māori claims and voices through the meanings that tūpuna and whakapapa held for tribes. This negotiation helped French museum professionals to get a better understanding of what mātauranga Māori meant not only in general terms but also in terms of museum practice. As my interviews and documentation of the process has shown, French curators, therefore, had the chance to share different perspectives on Māori terms, such as taonga or kaitiaki, and to try to elevate these voices for their audiences in exhibitions and meetings following the ceremonies. French museums consequently took the opportunity to connect their own academic or scientific knowledge with primary Indigenous traditions and knowledge. This insight led my research to focus on the question: Can Toi moko be considered living fragments of French/Māori history?

Working with Māori experts on taonga Māori also influenced museum roles in terms of exhibitions, communication and contemporary arts. MQB-JC and the Museum of Rouen worked with Te Papa's mātauranga Māori team in order to create exhibitions and organise post-repatriation events. Artists were also involved in the process, like Derek Lardelli and the attendance of Toi Māori members at the closing ceremony and repatriation at MQB-JC. Mark Kopua and Taryn Beri were involved in the exhibition Tattooists, tattooed and the partnership of Tracey Tawhiao, Shannon Te Ao and Michel Tuffery and other artists from New Zealand and Pacific islands in 2015 were the central events of the festival Pacifique(s) Contemporain.

On a long-term basis, George Nuku has been invited to several museums in France to present his work (Rouen, Paris, Bourges and currently Rochefort), and everything started with the repatriation. This invitation has been also quite challenging in terms of communication about tikanga. Because the process of return was the first experience between French and Māori in museums fields, the French public tended to accept every speech made by Māori representatives during and after the process. When George Nuku said that he was opposed to the way repatriation was accomplished today, several museum professionals questioned the significance of returns. The return of Toi moko helped them to understand there are various opinions within Māori communities regarding repatriations, funeral commemorations and personal understandings of tikanga.

Therefore, I would argue that repatriation is not just one temporary event or operation but is an important phenomenon which could lead to a better recognition of Indigenous principles 
on French soil. This return of ancestral remains led French museums such as the Museum of Rouen or the MQB-JC to think about different ways to work alongside Māori professionals to present exhibitions according to their mutual perspectives (Western and Indigenous).

\subsubsection{Ethics and Dignity of Human Remains in public collections}

Ethics and dignity of human remains are two principles used in the museum practice of preventive conservation. The concept of ethics has been widely debated during repatriation negotiations in relation to its application to all human remains preserved in the collectionknown or unknown, identified or not, foreign or French, colonist or colonised. My discussions with repatriation practitioners confirmed that there is poor treatment of human remains in museum collections. Among the extensive number of human remains, many were simply hidden, forgotten, or preserved in bad conditions. My goal was not to judge the way to preserve human remains, however, but to elevate this analysis in order to understand the underlying factors and finally clarify museum repatriation practice. The reason why museums are supporting repatriation today is that they have their own legacy of collecting, which was revealed in chapters One and Two. Reconciling their own historical actions with today's practice is part of the present ethical approach of museums, to make up for past 'sins'. French speakers in public events also use those two words extensively — ethics and dignity - during repatriation ceremonies in France and Wellington in order to show their respect regarding Māori culture. It was during those encounters that the repatriation process brought out values such as morality, agreement, and mutual understanding.

Once the Museum of Rouen decided to return the Toi moko from its collection, the paradoxical legal status of human remains in the museum has been at the centre of discussions. Article 16-1 of the French civil code declares:

Everyone has the right to respect for his body.

The human body is inviolable.

The human body, its elements and its products may not form the subject of a patrimonial right.

The act of preservation, study or exhibition of human remains must respect the principle of dignity applied to any parts of the human body preserved in public institutions. The Toi moko was, however, part of the museum's collection under the status of Musée de France. And the 
Heritage Code is clear about the imprescriptible (art.L.451-3) and inalienable (L.451-5) character of such collections. This paradoxical interpretation in French legislation was predominant from the beginning. On the 27 December 2007, after the cancelled repatriation ceremony and despite the agreement of the city council, the administrative tribunal cancelled the city appeal in favour of the repatriation. In July 2008, the administrative appeal court of Douai confirmed the decision made by the administrative tribunal of the city of Rouen and the administrative judge recognised that the human remains preserved in the museums belonged to the public domain (Administrative Court of Douai, 08DA00405). This decision reflected the ambiguous legal and ethical position of human remains in museums and reinforced the idea that the "French tradition in heritage law is to preserve and only occasionally to exchange" (Lepers in Fontanieu 2014, 220). This statement was also debated during the international symposium hold at the musée quai Branly in February 2008 during the third round table titled "Human remains status according to legal, ethical and philosophical perspectives". This was an occasion to discuss the constant evolution of perspectives on human remains in museums taking into account different periods and approaches. Marie Cornu, jurist on the legal status of human remains in museums, presented her argument about the legal decision according to the ethical dimension of human remains in a contemporary context.

For the lawyer, it is quite simply the idea that only the living person is able to exercise rights, to be the subject of rights. The human body is one thing. However, is it really an object of property ? [...] The human body is a sacred thing, not in reference to a religious dimension but in that it encompasses respect. No one can undermine his integrity. The question is to know to what extent this principle contains the powers of the owner (Cornu 2008, 83).

International conventions such as the Convention for the Safeguarding of the Intangible Cultural Heritage, signed in 2003, the Convention on the Protection and Promotion of the Diversity of Cultural Expressions, signed in 2005 and the Declaration on the Rights of Indigenous Peoples signed in 2007 framed international policy concerning the need for returning human remains to their communities of origin.

In the French case, Michel Van Praët explained during his interview, that no one developed a better understanding of one other legal point that should be taken into consideration. No one 
wanted to talk about the fact that the Toi moko of Rouen was a donation (van Praët, 42'min). According to the Heritage Code (L451-7), a donation cannot be deaccessioned. Moreover, most human remains in public collections have been given or bequeathed by the collector or the collector's family. The complexity of the legal situation and the failed attempt to return the Toi moko in 2007 represent this constant changing of perspectives towards human remains and especially Indigenous ancestral remains.

Keeping tracks of donations [to museums] also means questioning the meaning this bequeath acquires in a political and cultural context. It is a system of values and attachments that reveals and sometimes creates a crisis: testifying to a consensus around national culture, the gift nevertheless establishes hierarchies between metropolitan legitimacy and colonial legitimacy. (Saou-Dufrêne \& Djenidi 2018, 169)

Those legitimacies are at the heart of the process of repatriation, temporarily at least. By listening to Indigenous voices, Western museums are directly questioning the principles of ownership and acquisition, and the ethics of preservation. What should we do? Follow moral ethics by discussing with Indigenous communities or apply scientific ethics that avoid the deaccessioning of human remains from public institutions in the name of universalism. The last comment of Michel Van Praët during his speech at the International Symposium at the quai Branly in 2008 also reflected this idea of dialogue allowing a better comprehension of each claim and decision making between museums.

It is by working on the diversity of formulas that allow the conservation and dignity that we can arrive at more general solutions that would avoid laws of circumstances or political gestures that we prefer not to privilege: negotiations from museum to museum seem to us professionally interesting. I would therefore like to end with these elements: negotiation, mediation, the taking into account of others, and finding solutions which do not create 'holes' but which also allow restitution. (Van Praët 2008, 90)

In New Zealand, as my research in Chapter Three shows, the ethical approach to Māori human remains is completely different. The government mandated KARP and throughout my experience with them I observed the logistics within Te Papa as the institution where all Toi moko are temporarily preserved before finding their final resting places. The creation of the wāhi tapu as a sacred place to look after the human remains shows the unique place of Māori 
human remains held inside the museum. The support of experts who are members of RAP help in discussions about KARP's future planning to realise the national aspirations of the programme. The constant question in my mind when I went inside the wāhi tapu is: Am I supported by iwi to work on ancestral remains with high spiritual values? The use of te reo to define any part of the tikanga connected to the research on human remains, and the involvement of teams other than KARP for the organisation and accomplishment of the ceremonies, demonstrate the high value held by the museum towards Māori ancestral remains and the tikanga applied to them.

During the repatriation ceremonies observed and then analysed in this thesis, respect for the dignity of the human body was predominant in every speech given by all participants, French and New Zealand. This diplomatic use of the concept of dignity demonstrates a desire to recognise the human heads as Māori ancestors and not just anthropological artefacts within a Western scientific scheme. This recognition of the Indigenous identity of human remains is proof of the respect that French museums showed towards them-dignity returned to Toi moko after more than 150 years in French public collections. By enlarging the ethical dimension to apply to every taonga still in their collections, French museums have expressed their desire to gain more knowledge about modern Māori cultural identity.

By using this concept, French and New Zealand museums acknowledge the ICOM Code of Ethics and other international conventions that create modern paths to reconnect ethnographic collections to communities of origin. The act of repatriation is not mandatory and every request should be approached following careful research and analysis of the particular situation at hand in order to create the most appropriate response according to the respect extended to human remains and the living communities of origin. Puawai Cairns developed this idea during her interview by saying that all human remains should come back to their lands of origin, but they should come back with a plan (Cairns, 38 ' min). This plan could refer to proof of logistical dignity given to human remains. According to Cairns, repatriation should apply according to a procedure that mixes logistical and moral approaches. In the repatriation process, the dignity of human remains depends primarily on their return to their lands of origin but also on their deposit in a final resting place. On this point, negotiation was not just focusing on the Western and Indigenous perspectives on human remains but also on the place of human remains within museums. 
Despite the official request made by KARP to see all Maori human remains returned to New Zealand, many ancestral remains are still located in museums throughout the country. What should the New Zealand government do about them? Return them without questions? Wait for official answers? To answer those questions, a collective comprising museum professionals has recently been created- Kaihurahura Whakahoki Kōiwi Tūpuna o Aotearoa. The ethical approach applied in the repatriation of kōiwi tangata and Toi moko should also be applied for the return of foreign human remains from New Zealand museums to their home region, working in partnership with local authorities of the deceased's community of origin.

\subsubsection{Cultural Diplomacy}

Cultural diplomacy has provided a method of communication throughout all the repatriation processes observed in this study. Cumming's definition introduced in the literature review is a concept that "refers to the exchange of ideas, information, art and other aspects of culture among nations and their peoples to foster mutual understanding" (Cumming 2003, 1).

Diplomacy is not only used by and for states or countries, museums and other institutions but can also be used as a diplomatic method to communicate topics such as repatriation. My experience in the process of repatriation shows this interest in building mutual understanding. A French student completing the first internship ever carried out at the repatriation programme at Te Papa has also some diplomatic repercussions in term of negotiation. Several interviewees have also acknowledged the key role of the two embassies located in each country in the nature of the relationships that have been created through the process. Embassies helped the encounters and advanced the dialogue in each territory. I remember the first time that Michelle Hippolite arrived in France on the 27 June 2010. During her entire time in France, she was accompanied by Embassy representatives and this small delegation came to the Museum of Rouen to finally meet the director of the museum. As soon as I arrived, Michelle said that she was "happy to see a familiar face" present in the meeting about ancestral remains and their future returns. This encounter was further proof of the ways in which repatriation presents an opportunity to speak kanohi ki te kanohi, face-to-face.

Interviews with participants in events and the transcriptions of their interviews enabled me to understand that the key to resolving the debate on repatriation is, predominantly, not in receiving permanent answers but in establishing ongoing mutual understanding between practitioners. Because the repatriation of Toi moko did not concern only curators and museum professionals, but included people engaged in the wider social interactions that embodied the 
complex pattern of repatriation, cultural diplomacy was a useful analytical lens in this research. The negotiations took nearly five years and throughout this period there were various courses of action employed to exchange ideas and values in order to create the appropriate conditions to return the ancestors. In New Zealand, the creation of KARP and relationships sustained between researchers, politicians, museum authorities and iwi can definitely be seen to be a form of cultural diplomacy. In France, the repatriation of museum collections not only concerned museum professionals but also senators, academicians, writers, journalists, and scientists. It is important therefore, to acknowledge the observation made by Christine Sylvester, professor in International Relations, that the advancements of the role of museums in the nineteenth century caused them to increasingly embody "internationally implicated/socially situated social institutions", inevitably causing them to become institutions that are "heavily political" (Sylvester 2009, 3).

Cultural diplomacy was also helpful in analysing and understanding opposing views concerning issues such as secularism, colonialism, human remains in museums, universalism and inclusive museology (see the next section of this chapter). The repatriation of Toi moko did not answer to questions related to these issues linked to museum history but was associated with them. In practice, a lot of speeches during negotiations and ceremonies were referencing to the transparency as a key part of the success of such an operation (Mitterrand 2012; Morin Desailly 2012; Cornell University Webinar 2020). In this sentence, I understand 'transparency' here to mean that no museums hold secrets or are engaged in such significant controversy that discussions on repatriation negotiation could be prohibited. But France and New Zealand still have some internal conflicts on several subjects clearly linked to the return of collections and particularly to the repatriation of human remains. France, for example, is still struggling with the role of the collections acquired during the colonial period, and New Zealand museums are holding human remains from other Polynesian communities or even Egyptian mummies in their storage.

Negotiations towards possible repatriations should not be analysed as independent cases and separated from each other. The repatriation of Toi moko is quite unique in France because it is the first time that an entire collection has been the subject of such requests but it is not the only one and some others are on their way. Furthermore, contemporary issues in which repatriation is playing an important role still need answers within the museum environment and society as a whole. Museum and colonialism, universalism and Indigeneity, the place of human remains in museum collections, the reflection by museums of current society issues 
(Black Lives Matter, for example, and the attempt to take back home a funeral pole from Tchad in MQB-JC in June 2020.) All these topics are linked to international and intercultural relationships and, together, help to conceive political and cultural directions in order to accomplish repatriation operations. To sum up, we can see that through the repatriation process museums are rethinking their models and roles. It is not that they are transforming knowledge, but museums are rethinking the ways in which they can share knowledge and what knowledge they want to communicate to the public.

\subsection{Discussion of related issues}

As this thesis shows, every stage of the process of repatriation of human remains between France and New Zealand is a source of negotiation, debates, and uncertainties. Many important issues are debated: the place of human remains in museum collections, the ability to work with source communities, the proposed laws and policies, the role of museums in reconciling colonial heritage, the universalism of museums, the indigenising of public cultural institutions, the relationships between museum professionals from Europe and the Antipodes, the imbalance of power between international/European museums and others but also locally between parisians museums and regional museums, and, finally, secularism and the place of spiritual ceremonies within French museums. Each of these points has been a source of argument. My research has led me to think about the intimate links between current museum activities and repatriation and especially the question of how repatriation can be considered a museum practice.

To answer this question, I have drawn on my own personal involvement, and interactions throughout the process of repatriation in France and New Zealand, in the form of an autoethnography, which has critically examined several challenges met by museums facing the daunting prospect of repatriation. Ten years have now passed since my first internship in 2009, and the eight interviews included here as part of this research were conducted in 2019. This 'long view' over a decade has been a key factor in helping me to understand the slow but gradual changes made over time, the challenges met and the decisions reached by museums at different times. Are there any issues raised during the repatriation process that remained unanswered?

My research presented in this study, including the documentation of the outcomes of repatriation negotiations, the repatriation process itself and personal observations and data from interviews, has enabled me to analyse the nature of the repatriation process between 
France and New Zealand. The six themes presented above emerged from this research and throw light on the debate about repatriation which, I argue, can be seen as a modern museum practice. There is not just one way to observe and analyse the nature of relationships between museums in this situation and this variety makes the analysis of the results of such operation very complex. Nevertheless, with these themes, I have captured different aspects of the doubts, negotiations, and questions raised during my personal involvement in the research field, including internships, interviews, fieldwork and research reports.

Historical analysis seemed the first step to answer the question of reliability of repatriation in the museum environment today. The collaborative approach applied in this research to contextualise such acquisitions helped me to analyse Māori human remains in French collection with a fresh eye. The creation of themes created a better understanding of subjects that reflects the long-term negotiations between France and New Zealand but also within both countries. Studying repatriation has revealed the various positions taken by the museums involved. I chose to analyse repatriation not essentially as a redemption action but to focus on the future and consider it as an action that helps to clarify the definition of today's museum in a post-colonial period. Are the first principles of ownership or universalism still the same? Have they changed over time? These questions reflect the difficulties that Western society faces today. How will museums find answers to these questions if the society in which they are located is unable to gain a better understanding of cultural identities? The analysis of my data prompted other questions and repatriation is, I believe, a way to get closer to proper answers.

\subsubsection{Universalism and the indigenisation of museums in a globalised system}

Based on my analysis of the repatriation processes in this study, I would argue that the lack of understanding about Indigenous cultural identity in modern society has undermined the concept of universalism within French museums. What is universalism in the $21^{\text {st }}$ century without human interaction and contact or mutual understanding? The repatriation procedure examined in this research can be considered to be an ontological case study of the role of museums today. Museums need to reflect as much as possible on their contested political power derived originally from Western colonial empires. Since the $19^{\text {th }}$ century they have been considered to be respected and trustworthy places for the transmission of universal truth and knowledge. However, despite efforts since WWII to present the museum as a place for all members of the public, and the growth of the 'new museology', it is questionable whether 
certain museums have made this transformation with regard to their role and their use in modern society. These efforts are reflected in the creation of ICOM in 1946, founded on the attempt to create a 'universal' definition of museums by including not only traditional Western ontology but also gradually including communities' and minorities' values of tangible or intangible heritage (Brulon Soares 2017, 163). I have the impression that when they opened Western museums opted to increase the number of objects that comprised their collections despite the quality of provenance information associated with them. In order to further their Western sense of universality, curators and scientists, at this time, collected and exhibited objects without any Indigenous perspectives.

As a result of this study of the historical background of Toi moko, I argue that museum collection acquisition is founded on the desire to include all types of humans out of curiosity and with no regard for collaboration. The acquisitions of Toi moko by Drouet in Rouen or by Dumont D'Urville, described in Chapter Two, demonstrate a sought-after, individual recognition of an artefact by their donors. Other acquisitions like that displayed at Printemps" described in Chapter Two are examples of gallery exhibitions according to what Western social codes defined as 'curiosities'. In every case, the examples in this study of collecting in the form of Māori Toi moko acquired by French institutions, demonstrate a certain lack of understanding and empathy towards the richness and pluralism of tribal Māori cultural identity. In their approach to Toi moko, Western scientists appear to have reduced Māori into one unique category, ignoring all the diverse tribal perspectives. In the case of ethnographic collections and including human remains, attempts to discredit, diminish or ignore source community perspectives was quite common in the museum field, in fact, even the act of hiding the collection was favoured in certain circumstances. This avoidance of social relations or even contact reflect the Euro-centric approach of the traditional museum policy.

The evolutionary principles of classification based on theoretical understandings of social Darwinism drove museology and exhibitions all through the $19^{\text {th }}$ and 20th centuries. This fascination for foreign items created stereotypes and also shaped general perceptions of foreign communities in France. In addition, universal exhibitions in Western countries tried to convince audiences of their role and status which was 'scientifically' proved. The data gathered during my fieldwork shows that these historical attitudes are still very much prevalent. As Roger Boulay explained in the interview the concept of heritage is not applied in the same manner as for Indigenous communities. 
Because they did not have any close contact, European curators and museum professionals maintained an imagery of the 'Other' based on stereotypes and European understandings of a few Māori customs such as haka or tā moko. This tendency to freeze Indigenous cultural evolution also reflects the argument of David Butts, who points out that objects in museums are 'suspended' at the same time as their communities of origin. Western museums preferred to develop exhibitions and convey ideas of Indigenous people denying the engagement with modernity by Indigenous communities (Butts 2003, 44-45). But despite the influence of racial classification in French museums, contemporary social changes in Indigenous life are noticeable in terms of the classification and information provided in museum galleries. My research shows how this change occurred thanks to the creation of relationships and the mutual understanding that it engendered between museum staff and foreign ethnic communities. The repatriation process can therefore be considered a foundation for better relationships between museums and communities, and an integral part of professional practice that provides access to other more informed and sensitive modes of exhibition presentation.

As my case studies of particular repatriation operations show, the process strengthens the impact of Māori protocols within Western museum policy and international exhibitions focusing on te ao Māori. The neologism presented by the expression "inclusive museology" was effectively put into practice through the repatriation programme itself which created a rupture with past hegemonic Western museum classifications and procedures. In order to learn as much as possible about the appropriate use of Māori collections, French museums had to collaborate with Indigenous researchers like the staff of KARP, myself included, in order to understand the situation, the different cultural perspectives, and to realise the benefits of such programmes including gaining more experience with international institutions. As I have shown in Chapter Three, Te Papa is an example of a distinctive bicultural administration which helped French museums to understand that museums can work carefully and sensitively with a broad range of Indigenous intellectual and cultural property.

Contemporary Western societies and their cultural institutions are coming to terms with a contemporary context of debate and tensions between their colonial political origins and contested history and the contemporary values of minority communities including Indigenous people. The museum repatriation practice emphasises cultural diplomacy to engage with and acknowledge shared values through cultural events and exchanges such as the return of Māori ancestral remains. Furthermore, thanks to diverse exhibitions post-repatriation, French museums have had more interest in understanding Māori concepts such as mātauranga or 
whakapapa and their value in modern society. Therefore, it can be seen that repatriation as a museum practice has helped to construct a more accurate interpretation of Māori cultural life in terms of contemporary cultural significance without seeing Indigenous people as 'stuck in the past' or as an undeveloped community but presenting them instead as modern agents in cultural diplomacy and international relationships. In the case of relations between France and Māori, repatriation was the foundation of living museum agreements on which future collaboration was based, as witnessed on occasions such as the Māori exhibitions at the MQB-JC, the reception of contemporary artists and art works for festivals. As the chapters demonstrate, I was personally involved in these exhibition and cultural collaborations from the start of my research, and saw first-hand how they presented a different view, changed peoples' attitudes and transformed the way museum professionals worked.

We find today in the public debate in France the contradictory heritage of the Double Universalism put in place in the 1930s: opposition between Pluralist Universalism claimed by the MQB and the Assimilationist Universalism that expresses the idea that immigrant populations from the ancient empire have to conform to a "national identity" and simultaneously refuse the "multiculturalism", deplored by the term "community". In other words the possibility that personal identity is defined uniquely by its affiliation to one cultural community. (de l'Estoile 2007b, 12)

This research suggests that repatriation as a professional practice is helping museums to better engage with Indigenous communities to collect, exhibit and present public programmes and, therefore, may play a role in the conception of a new pedagogy which can help museums to face societal issues such as climate changes, racism and multicultural differences and tensions arising from misunderstanding and inappropriate use of objects in museums. As Brulon Soares has argued:

But in order to think globally in a post-colonial world we should at least be asking who is asking the questions in the first place. This reflexive exercise - that should be implied in the ICOM proposal to rethink the definition-may expose the different disputes and negotiations over the power to define the museum that determined the definition we have today, and it would allow us to consider its impact on the plural contexts where it is and will be applied. (Brulon Soares 2017, 167) 


\subsubsection{Repatriation and colonisation}

Invasion, exploitation, and colonisation had an extensive significance in terms of the role of museums within Western society. Paradoxically, the collective Western imaginaries diminish the consequences of the occupation of foreign territories, transforming or even romanticising them, sometimes assisted by media, films or books. A natural history museum was first introduced according to the richness of the collection not its acquisitions. Another example developed by Pascal Blanchard in his discussion of why France does not have a colonisation museum (Blanchard 2018, 4'min) is that pictures included in history books used in schools are evidence of efforts by the French government to attenuate the impacts of colonialism. Most of the pictures of foreign countries at the time of invasion which are held in French archives have been taken solely by the Agences Economique des Colonies. Today, the French public has forgotten this monopoly of media circulation and proving fears that the French republic coveted the so-called positive aspects of such actions against human rights. The French authorities attempted to control communications concerning the actions of the French Empire and, later, the French Republic in foreign territories (Blanchard 2018, 20min). This colonial propaganda has been accepted by the public through the years and today French audiences cannot imagine that France applied such processes to shape public opinion. This same approach has, consequently, been used and communicated inside museums in France. Dialogues with communities of origin were completely lost because French curators did not consider Indigenous people as humans or maybe placed them in lower positions in a racial classification.

Because of these imaginaries and their individual images and ideas of foreign places and native/tribal peoples, colonisation appeared to be the subject of a historical period. Because colonisation as a period is not studied in detail in the French educational system, it appears that French people conceive of most of the consequences of colonisation according to their own personal understanding. Confirming this point, according to Pascal Blanchard, is the fact that among the 12,744 museums that exist in French territory, none is focused on the colonial past (Blanchard 2018, 3min). In the United Kingdom, these complex issues about the colonial past are also noticeable in the short-lived attempt to set up a museum focused on this phenomenon, located in the famous port that took a key role in the colonial travels, the city of Bristol. The British Empire and Commonwealth Museum opened in 2002 and closed in 2013. In France, a museum of colonisation project was cancelled by the government in 2015 . The 
study of colonisation and the genesis of museum practice as we know it today in Europe appears, consequently, to be quite abstract.

However, thanks to concrete events such as symposiums, conferences and congresses at an academic level but also through exhibitions and inter-cultural meetings that, as this thesis shows, are part of museum practice, an opportunity is provided on different occasions to build or deconstruct collective imaginaries. Those collaborative attempts help to analyse such a historical period with the help of museums and their relationships. In this way, the repatriation of human remains from museum collections appears to be an agent of change that allows French and Māori professionals and communities to analyse a shared history, including novel elements such as the little-known French involvement in the trade of Toi moko. This process has also helped to make the French public more aware about the French historical presence in the South Pacific in general. The involvement of museums in such programmes reflects the desire to clarify the complex role of such institutions regarding the French imagery of Māori cultural identity since the beginning of the $19^{\text {th }}$ century. As Pascal Blanchard has explained:

When you don't have museums, you don't make history. This history is not pacified, it has not entered collective memories. It is not history that is simply neutral. When you enter the museum, it is not simply the fact that the idea, the subject or even heritage, has value is that there is, in the French Society, the capacity to be able to neutralize a hot question to, little by little, make it available to citizens and the general public to talk, debate and understand this question. (Blanchard 2018, 23’ min)

Answers to the questions that surround colonisation, in my opinion, rely too much on personal interpretation. The French educational system is not answering questions re the colonial system and does not introduce the main events of decolonisation such as the Algerian War. Individual interpretations of such periods maintain duality and tensions that exist between different groups and inhibit progress and settlements of repatriation claims and disputes.

Events post-repatriation have provided another opportunity to understand this gap between French Indigenous imaginaries and the strength of Māori cultural identity. The closing ceremony of $E T \bar{u}$ Ake in Paris was an occasion for the French public to understand the tapu dimension of each taonga exhibited at MQB-JC. 


\begin{abstract}
Museums are not realising that we are doing this. When we are in a tangi within our community, part of the process of completing the tangi is you have a formal ceremony but you also go back to where the people live, and we call it the takahi whare and also to clear the space. And it is actually what we are doing when we are overseas, we actually clear the space. And because our ancestors have been in those museums or institutions for a long period of time we say takahi whare. (Herewini 2019, 43'min)
\end{abstract}

Every action regarding taonga and kōiwi tangata is carried out under protocols. There is debate concerning the secular dimension of public institutions in France but repatriation allowed cultural events to be organised not under French management but Māori/French management. Lifting the ancestors from overseas is an occasion to develop Māori cultural perspectives beyond New Zealand borders. The opening of Bottled Ocean 2115 exhibition by George Nuku in Rouen on 12 May 2015 was another complex mix of cultural presentations and diplomatic expectations. George Nuku wanted to include a pōwhiri as an opening ceremony. He and the museum needed to be quite clear on the definition of pōwhiri to be explained to the public. The museum director and George Nuku asked me to translate what was said. We took a few minutes beforehand to explain to the public that the museum representatives, George Nuku and his friends were the tangata whenua and all the others would be considered as manuhiri. The New Zealand ambassador at the time, James Kember, was invited and George Nuku challenged him on his arrival with the mayor of Rouen, Yvon Robert. The ceremony in Rouen was an occasion to include the public in a Māori ceremony and give them the opportunity, which I had several years before at Te Papa, to experience Māori cultural richness.

Each opportunity to experience Māori cultural ceremonies, repatriation, whare, pōwhiri is the ultimate outcome for a French audience. Having the opportunity to see Māori applying tikanga in France is another result of a different reading of the colonial past. It is an invitation to mutually understand the different role of museums and to comprehend the stories told through exhibitions. To me, those experiences, kanohi ki te kanohi, are the outcome of the collaborative method to deconstruct our perceptions not only of the colonial past but also of the present. 


\subsubsection{Human remains and science}

This thesis shows how human remains in French museum collections have been alienated from their primary status as human. As soon as European settlers arrived in New Zealand, the encounters with Māori transformed the original meanings of Toi moko within Māori society. Māori communities also played a role in this transformation. The trade in Toi moko and the 'weapons race' of the 1820 s engendered by the settlers' presence are key facts in the historical journeys of Māori ancestral remains that ended up in European collections. As we have seen in the previous sub-chapter, it is hard for European museums to understand that the role of Toi moko evolved at the same time as Māori culture. Convinced that Māori were a dying race, Europeans became possessed by a frenzy to acquire Māori human remains, an action which was related to fundamental scientific ideas about racial anatomical comparison. As I pointed out in Chapter Two, the European comparative practices of phrenology and anatomy were examples of unethical Western evolution investigations without the consent of or collaboration with descendent communities (Tapsell 2005). The removal of phrenology from the scientific field after decades of practice demonstrates also that this questionable investigation of evolution was essentially based on Western analogies.

Regarding the topic of scientific research and repatriation, the biggest challenge today is achieving mutual consent between Indigenous and Western researchers. The hotly debated topic reflects the imbalance of power which has been maintained since colonisation and reinforces a system of racial classification. Western museums were more in favour of working with anthropologists and ethnographers than with the descendent communities. This fact is related to a fear that all communities will ask for the return of all collections. And because Western scientists especially did not consider Indigenous people as worthy to work with, they were at the bottom of the racial classification system, and were considered to be needing help from Western science to provide enough support to avoid perishing. That's one reason why museums from Europe trusted European scientists more than a Māori tohunga or any highly regarded Indigenous leader. This point was made strongly by one of my Māori respondents:

Science, on the other hand, has taken much longer to shift its view of the scientific pursuits which were seen to be more important than those of the indigenous peoples whom they studied. Even in the twenty-first century the idea persists that science and the potential knowledge it can uncover are 
more important than the cultural beliefs and practices of the people they study. (Aranui 2018, 91)

As described above, one Toi moko became an artefact exhibited in a famous department store in Paris- Printemps. Egyptian heads became elements of décor like lampshades at the Musée des Arts Décoratifs. European scientists and curators did not hesitate to complete the facial tattoo on Toi moko themselves or transform the shape of Mexican skulls or put emeralds replacing eyeball to use them as decorative lights (Van Praët, 35'min). All these actions were carried out in order to prove the alleged savagery of native or tribal communities. Human remains can therefore be understood as significant artefacts of Eurocentrism and the colonial past of museums. The changing meaning and nature of their use through the years, which is laid out in this study, shows how things have changed over time, including museums, which today try to create better mutual understanding with Indigenous communities. Repatriation can therefore be considered, in my view, a diplomatic action.

We also realise that we actually need to wrap what we are doing in a way that people will understand. That's why we are doing presentation or will have open discussion around repatriation process. Why is it important for Māori and Moriori and we are also discussing about what happen after the ancestors come home. Once they left the institutions, the process is accomplished for them but the process hasn't been completed for the ancestors. The same with the TM in France. Part of the legislation is that there is some requirements that we have to meet such as we can't do DNA Testing, that they would be buried eventually. And the historical research that we have done. So those things, Te Papa needs to be specific. (Herewini 2019, 44'min)

KARP is applying research according to both Indigenous and Western ethical protocols. What Herewini highlighted during his interview is the complexity of introducing the repatriation programme without previously introducing some tikanga that characterised the creation of such programme. That is why science and repatriation are not necessarily in opposition, but in the context of no contact between Māori and European authorities, an ethical approach would be contradictory. As I show in Chapters Two and Four the contemporary values of Toi moko for anthropologists and Indigenous researchers are quite different, but for scientists and museum professionals to give up control is actually to gain something. Establishing a 
relationship through the practice of repatriation gives the museum much in return. As Aranui puts it:

The balance of power does not always have to be one way or the other, and it shows that creating real and meaningful relationships with communities can open up opportunities. It also shows that the relinquishing of control does not necessarily have to mean the loss of knowledge. (Aranui 2018, 90)

In the manner of Western scientific monopoly, the MQB-JC, after the first negotiation, quickly decided to learn as much as possible about each of the Māori heads in the collection. Because the museum was afraid to lose all the data with the return of the remains to New Zealand, curators worked with Philippe Charlier, medical examiner and anthropologist to undertake DNA, Xray, IRM and photographic (classic and infrared) analysis of the seven Toi moko still in the collection. Philippe Charlier was already renowned for his involvement in the debate around the head of Henry IV in 2010.

In 2012, KARP asked me to undertake the translation of the report sent by the MQB-JC to make the repatriation programme aware of the final results. The report is mostly conclusive as to the age of each deceased, their anatomical examination and sometimes the cause of the death such as head injury caused by Māori weapons (taiaha, tewhatewha or mere, for example). Already aware of Te Papa's position towards the medical examination and manipulation of ancestral remains, the MQB-JC insisted on carrying out such research to assert the origins of each set of remains. The final point of the report was, thus, the discovery of the type of diet of each ancestor and scientific proof or evidence of their Polynesian ancestral affiliation. This kind of formal academic analysis is typical of the imbalance in terms of research by Maori and Western professionals. The repatriation programme was already certain of the ancestors' ancestral affiliation, but it was considered to be necessary for the MQB-JC to use science in order to see all the remains return to New Zealand.

- Two of the Toi moko had diets based on proteins from fish and marine mammals;

- One had a diet based on the protein from land-based mammals;

- The last four may have had vegetarian-based diets; and

- DNA results obtained from the seven heads concluded that they may come from one of these following locations and populations including: Tahiti, Rapa Nui or New Zealand. (Quai Branly report 2011, 2) 
These results could be useful to work in collaboration with Maori authorities. However, by carrying it out just before the repatriation, this action could be seen as an untrustworthy action. Because the Toi moko were leaving the French museums, scientists considered it important to undertake research, the results of which Maori authorities were already aware of without manipulation. Maori researchers could tell French museums what the diets comprised during the first decade of the $19^{\text {th }}$ century in New Zealand, and what could have been the causes of the deaths. Why did we have to know that for each single deceased when the French did not even know the contexts of their acquisitions? Here lies the imbalance between Indigenous knowledge and Western universalism. It is an example of how science is considered to be more trustworthy than mātauranga Māori. Why could these data not be combined with Māori knowledge from the beginning of the negotiation in order to undertake a complete analysis of the journey of Toi moko in French museums?

\section{Conclusion}

In this chapter I have suggested several answers to the research questions, developing arguments that emphasise the policy, practice and process of returning ancestral remains from French museum to local communities. The case of Māori Toi moko, it seems to me, shows the different levels of debates and struggles, from both the New Zealand and French sides, that helped to transform repatriation from a threat, a risky and little-understood problem, into an accepted post-colonial museum practice. Through the cross-case analysis and discussion of the research data presented in the previous chapters, I have developed ideas, arguments and concepts that emerged from my analysis of the complex process of repatriation and events that followed.

One of the main conclusions of this chapter is that is difficult to answer so many different questions arising from debates and challenges. In my view, the practice of repatriation should be applied with care, diplomacy and clear policy. In France, the concept of ownership is still essentially ascribed to a museum, and the process of repatriation does not question its application but its effect on modern society. Museum practice in the post-colonial period reflects these debates about the elementary principles that still define museum institutions. Repatriation is just one aspect of changes in the definition of museums around the world. This aspect has been one of the points highlighted by the discussion on the new definition of the museum and concepts of museums as participatory and transparent (ICOM 2020). Repatriation requires professionals to redirect their focus away from internal concerns 
with collections, and rather to use museum materials to collaborate with communities of origin and gain a better understanding of their perspectives.

Contemporary national cultural identity, in France and New Zealand, is impacted today by multiculturalism and globalisation, the wider context in which repatriation took place. Museums cannot avoid these globalised communications, contacts and relationships throughout the world. That is why French museums saw in this process an opportunity to work alongside kaitiaki to present some taonga to their local public. The research presented here shows how French museums, though world famous themselves, learned so much from engaging with very different museums in a small far-off country, and in so doing transformed the way they approached their mission and purpose with regards to Indigenous issues.

The historical analysis presented in chapters One and Two helped me to understand the context of acquisitions and questioned what I knew so far about Māori values and about parts of the French colonial past. Because the colonial period is not studied in detail in French schools, it seemed important for me and French authorities such as museum personnel and senators to gain more sense of the historical presence of French explorers, settlers, soldiers and fishermen in New Zealand since the end of the $18^{\text {th }}$ century.

Furthermore, the thematic analysis of the data gathered in Chapters Three and Four has been useful to address several questions asked by repatriation practitioners at the time of the negotiation including ones raised during interviews conducted seven years after the ceremonies in France. The interviewees shared the view that the ceremonies, and consequently the contact with each other, have been crucial in terms of mutual understanding. They helped them move beyond theorising and endless legal debates and instead focus on taking practical steps, developing relationships with New Zealand/Māori professionals, which in turn led to a higher regard for Indigenous heritage. Finally, I would now argue that the repatriation of Toi moko is consequently not a conclusion but a new beginning, an introduction, a way of transforming museums in the $21^{\text {st }}$ century. This thesis has shown that through the difficult process of negotiating repatriation the ways in which museums carry out their professional practice has been changed, leading to a different conception and vision of the museum's role in modern society. The attempt to take a funeral pole away from the MQBJC, the act of painting sculptures of men who participated in the slavery trade all over Europe, and the Black Lives Matter movement all reflect the lack of cultural recognition in the global culture system. For me, the discourse of repatriation is embedded in wider 
international relationships and schemes and we should therefore essentially focus on future collaborations including collaborative museology and shared authority, for example, through the label texts displayed beside each object presented in galleries.

The analysis and discussion of the research findings in this study, a diverse and original assemblage of data exploring repatriation from different angles, allows us to relocate the act of repatriation from a perceived threat to an absolutely core part of museum activities in the $21^{\text {st }}$ century. This post-colonial museology enables museum professionals to put into practice concepts such as networks, knowledge, mutual understanding, and collaboration that I argue remain central to the attempt to take a practical approach to the return of ancestral remains to their lands of origin, avoiding getting caught up in endless legal and ethical debates but rather getting on and doing it. As I argue in the conclusion which follows, Toi moko can be seen as significant tribal identity markers of the past and revitalised symbols of the aspirations of their communities towards a museological future. 


\section{Conclusion}

The aim of this thesis was to explore how the process of the repatriation of human remains has been conducted between France and New Zealand and to consider how it has shaped museum practice including subsequent post repatriation projects and mutual representations. I have addressed, in a critical and reflexive manner using appropriate theory and methods, the main research questions: Can the repatriation process be considered a postcolonial museum practice? How and why is repatriation practice related to the new inclusive museology, international dialogue and partnerships, and the acknowledgement of contemporary Indigenous identities in globalised museum networks? What has been the impact of the repatriation policy on the relationship between members of the Māori community and French museums?

The research investigated how repatriation affects the meaning, role and purpose of museums in general and how the act of returning ancestors has created a situation in which mutual appreciation, learning, adaptation and recognition emerged between museum and Indigenous communities despite their very different traditional missions and aims.

The research was framed by a review of the relevant literature. I employed useful theories such as the ideas of the "museum as a contact zone" (Clifford 1997, 192) and the museum as a tool to achieve the aim of "liberating cultures" (Kreps 2002) based on a collaborative approach to managing ethnographic objects in museum collections practice. I was also influenced by the notion of objects as material encounters (Thomas 2016) which helped me to frame my approach to the topic which investigated how Toi moko had influenced actors through the repatriation process. Thus, this study has built on the literature on repatriation and makes a contribution to our understanding of this complex topic, in terms of the in-depth analysis of repatriation not in theory but in current museum practice. My study focuses particularly on the repatriation of Toi moko between France and New Zealand and shows how the process helped to allay the initial fears about the process and concerns about the outcomes in the post-repatriation period. For the first time, France was involved in the repatriation of an entire collection and my study provides a detailed and in-depth analysis of this process of repatriation in practice, the first such academic study of this specific area. 
As I explained in the Introduction and demonstrated in the chapters, appropriate methods were employed to conduct this research and gather and analyse the varied data: namely historical archival research, case studies, action research, participant/observation methodology, semi-structured interviews and finally kaupapa Māori. In terms of the subjectivity, conflict of interest and matters of cultural perspective, I believe that my research methodology and strategy enabled me to navigate these issues and mitigate any risk. I was involved professionally in the sensitive repatriation process being examined, and I decided that my research design had to be multi-method, flexible and innovative. My strategy was to employ interdisciplinary research approaches centred on museum studies but also associated with museum anthropology, Māori/Indigenous studies and related disciplines focused on a case study. As a Pākehā, and moreover as a foreigner, the careful use of a kaupapa Māori framework was necessary in order to complete this thesis in an ethical and culturally aware manner. In a study centred on the return of human remains with Māori communities as primary research stakeholders, and applying Indigenous sovereignty through tikanga Māori, my attempt to understand its application in the museum field enabled me to acknowledge and incorporate Māori values in this research.

This study has provided a close and detailed insider observation of repatriation programme in process, from the initial negotiations to the post repatriation projects and challenges. The study of the general history in chapters One and Two has helped to contextualise the acquisitions by museums and the changing role of Toi moko according to its localisation. From tūpuna to curios, these first two chapters have given a better understanding of the global heritage attributed to Toi moko today. In the third chapter, I focus on the repatriation policy in place in New Zealand and how the process is linked to the broader cultural and political environment. The fourth chapter has answered the question raised in France about the application of repatriation policy in New Zealand. This part of the study gives clues to the close collaboration not only between researchers and iwi but also among museum representatives, and the increasing influence of Indigenous communities inside the museum environment. This influence can be seen not only in biculturalism and KARP at Te Papa but also through the subsequent creation of an entire network dedicated to repatriation issues in New Zealand: Kaihurahura Whakahoki Kōiwi Tūpuna o Aotearoa (New Zealand Repatriation Research Network). Chapter Five is a synthesis of several points which repatriation raised including the issues and struggles experienced by both countries. This key chapter has examined the complexity of the debates raised by the returning process and has discussed 
several themes which arose out of the case studies, namely the evolution of names, from theory into practice, repatriation as a strategy of interaction, as a method of (re)connecting, ethics and dignity of human remains and finally the cultural diplomacy. The main argument developed in Chapter Five is the relevance of the repatriation process within contemporary museums practices and try to understand the challenges facing institutional principles. I hope that my contribution to research on this topic provides fresh insights into the different stages of the process of returning human remains, its achievements as much as the struggles, and how it shapes and is shaped by the post-colonial period.

I grounded this research in museum practice by contextualising the repatriation in New Zealand and French museums through my experience working as a repatriation researcher. This study was mainly situated in the academic field of museum studies but my involvement with Māori communities allowed me to facilitate engagements with foreign museums to successfully realise the projects I was involved with. My profile could be understood as an intermediary between French and New Zealand authorities and opened up a variety of missions for me. I have been involved in the negotiations since 2009 through my historical and archival research, translations, meetings with authorities, learning process and participation in ceremonies or exhibitions, among other post-repatriation projects. This potential conflict of interest was managed by the careful way in which I acknowledged, documented and analysed my professional work on these projects, keeping a critical distance between my work and my research, and also the careful way that I worked with Māori professionals and community leaders, the details of which were included in my ethics application which was approved in February 2019.

Another event occurred during my time in New Zealand which explains my role as an intermediary. The French national rugby team came in Wellington in 2009 for a test match at Westpac Stadium (now Sky Stadium). During their day off, players and staff were invited to come to Te Papa for a private tour of the back-of-house collection stores and the marae Rongomarae and its wharenui Te Hono ki Hawaiki. Te Papa staff asked me if I could provide the translation into French about taonga and how to look after them. For the occasion, kaitiaki displayed the taiaha formerly owned by Te Rauparaha. This taonga is in the collections and usually not exposed to the public. Here, talking about this taiaha was the occasion to talk about the life of the highly regarded chief of Ngāti Toa who created the haka 'Ka Mate'. Because of the interest shown by the French team, it was considered to be an occasion to go deeper into the learning of Māori history such as the Ngāti Toa migrations, Musket Wars, Toi 
moko trade and Māori heritage through the preservation of taonga. Players were humbled to see this treasure and appreciated learning more about the haka performed today by the All Blacks and its historical meaning. I remember that they then asked for further information after the tour. Fond of rugby myself, I was only 21 years old and this experience showed me how the mātauranga Māori team at Te Papa put its trust in me to teach Māori cultural heritage to a French audience.

In the first place, I had a broader knowledge of French museums in addition to my experience at Te Papa which meant this research filled a gap in terms of repatriation experience between these two countries. My several internships and periods of work at Te Papa have been decisive in my understanding of tikanga Māori and I feel lucky to have had the opportunity to sustain these relationships and maintain my learning throughout the past few years. My participation in Māori activities inside the museum gave me an in-depth understanding of the challenges of such an institution in terms of engaging with biculturalism and Māori claims for the access to, return and control of their cultural heritage. Also, I was lucky enough to create key friendships with colleagues that helped me to ask some questions freely and raise issues and engage in debates that sharpened my perception of these difficult and often emotional topics.

Because I built these long-term relationships at the beginning of my involvement, and developed others in quite a short time frame, I had the opportunity to enhance my personal awareness of the crucial social feelings, understandings and perceptions of Toi moko by Māori people today. I was impatient to come back to get another chance to learn and work with KARP and NSTP. I really think that my experience as a repatriation researcher in two different countries is something that can be developed further, a new role in terms of museums and international collaboration, which I will describe further at the end of this conclusion. I admire French and New Zealand repatriation practitioners who wanted to see concrete outputs from my research including projects emerging out of this contact. For me, being exposed to and influenced by non-European museums is also a good opportunity to learn from different eyes, different approaches, questioning and revising museology, as the title of my thesis suggests. In this study, presenting issues and challenges that emerged from this process of repatriation negotiation brought underlying anxieties, misunderstandings, and conflicts of interest into the light. This experience makes me more critical about the concept of repatriation understood simply as an act of returning items. I was inspired by the words of Thythacott and Arvanitis (2014) cited in the Introduction, that restitution "is not only about 
the loss of objects for museums, but can be about important gains in terms of cultural relationships and knowledge." Repatriation should not be accomplished impulsively with mainly political reasons. For me, repatriation should offer answers to questions and provide opportunities to learn, to understand another perspective on history, but maybe in more important terms, it should also be productive, it should generate post-repatriation collaborative projects. Repatriation is not just about giving things back; you always get something in return.

The thesis structure in many ways reflects my own journey through the repatriation process in France and in New Zealand. In 2009, I barely spoke English and my involvement in the negotiations forced me to improve rapidly with sufficient vocabulary in the museum fields to be understandable. This challenge was not easy for me, but I think it was worse for my colleagues back then at Te Papa and friends who have supported me since the beginning. To be honest, my first impressions of repatriation and Māori claims were very positive and might be seen as naïve. When I started to work on the repatriation process, I had the feeling that Māori should be the only voice to be heard and all we needed to do was follow their lead. However, having completed this research now, I have a fuller sense of the complexities of the issues, so while I am still certain of their leadership concerning such operations, I feel that this needs to be connected with Western interpretations of Māori collections which were and are also part of the process of mutual understanding. It is a two-way process, not one-way.

The repatriation of Toi moko from France to New Zealand was an occasion to allow Māori to speak for themselves in a foreign territory without always focusing on past testimonies.

Despite the actual national policy on repatriation applied in New Zealand, the involvement of Indigenous professionals in museums is still in in its early stages. In France, the negotiation for the return of Toi moko concluded with the enactment of a national law allowed the return of not all human remains but specifically Toi moko to New Zealand.

This thesis makes a contribution to the museum studies and repatriation literature in France and in New Zealand by addressing the gap in the research on repatriation on the ground, that is, the history and practice rather than the theory and legal and policy debates. I believe that this in-depth study of repatriation has provided useful lessons about the comprehension and analysis of museum authority and changing appreciation of programmes which return human remains to source communities elsewhere in the world, although the research is somewhat limited in being specific to France/New Zealand. The invitation for KARP to sit at Te Papa in 
2003 and its mandated support by the Ministry for Culture and Heritage are key factors in legitimising repatriation as museum practice not only nationally but also internationally. At Te Papa, KARP is an integral element of the biculturalism system but in France, it is an ambassador of Māori cultural heritage. The value of the study therefore lies in the way in which repatriation is considered not as a temporary action but as an essential and permanent part of museum practice that has long-term effects. The repatriation ceremonies examined in this study therefore presage a mutual understanding that could lead to further collaborations in terms of museum actions and policies.

The period of negotiation between France and New Zealand (2007-2012) analysed in the chapters provided an exemplary case study of a dilemma in museology, applying the repatriation concept to Western museum practice in two different countries. Despite the loss of an object, what are the benefits for museums? Despite the different policies applied in European museums, consensus is revealed regarding the significant role of museums in learning about colonialism. Jonathan Fine, head of the Ethnological Museum of Berlin, acknowledged this role of museums during a zoom conference on 19 October 2020. Recently, Germany returned Toi moko and kōiwi tangata to New Zealand, and Fine explained that the public perception of Museum is also a key factor in the accomplishment of the process. His speech reminds me of what Sharon MacDonald pointed out, that "Museums are located geographically and politically" (Macdonald 1996, 5).

Today, museums are locally implemented into national identities in terms of administration and policies, but it seems also important to be able to reach every single person through the web. Jonathan Fine explained that "no matter where you are in the world, it is important to have access and to see what are in museums all over the world" (Webinar Cornell University 2020). European museums are thus engaging in the process of transparency and democratic actions and not speaking anymore solely to the upper class of Western societies. The postcolonial problematic raises questions about integration, representation, and multiculturalism. With Māori: their treasures have a soul French museums gave Māori curators and researchers the floor. This collaborative museology avoids the problem of representing one culture through another's eyes and instead creates different perspectives (Gagné and Roustan 2014). "These reappropriations show how much action on material things redraws their political contours," writes Mélanie Roustan, "between the memory of peoples and the history of nations" (Roustan 2016, 167). Roustan wrote an article about the 
use of Indigeneity in French museums and reflects on this fear of the French colonial past and its consequences in the relationships created between France and former colonial territories:

A quick overview of the museums reveals great voids on the most painful questions in recent history, relating to France's relations with its former colonies and their independence. There is thus a lack of contemporary museum treatment, whether historical, ethnographic, or artistic, of the colonial and post-colonial legacies of former French Indochina and Algeria. (Roustan 2016, 168)

Therefore, I would argue that research on repatriation such as the current study addresses these concerns about decolonisation and Indigenous engagement and documents an emerging new museology and museum practice better attuned to these challenges, which shapes and is shaped by an underlying process of mutual learning and dialogue. Repatriation brings Indigenous voices into Western institutions, and ceremonies are 'making things real' according to French repatriation practitioners. I had the chance to be part of several repatriation ceremonies but the one organised at Te Papa for the 20 Toi moko returning from France in January 2012 was a unique experience. I was not among the French delegation; I was a member of the Te Papa delegation (even though I am not Māori nor was I a permanent employee at Te Papa). Of course, I perceive the political message underlying this decision to return Toi moko, but on a personal level I consider this invitation to be an acknowledgement of my effort to learn and share information through the years, and of my strong relationship with New Zealand museums and Māori repatriation practitioners.

Historical approaches to this topic are important in order to acknowledge what taonga and whakapapa mean in te reo Māori. This type of research is also crucial in France so as to acknowledge the past and (re)define the role of museums according to past events. In chapters One and Two, I have highlighted this by conducting in-depth archival research about the history of Toi moko and their journey into French museums. The French involvement in this trade and the importance of ancestors for Indigenous people are keys to the comprehension of the entire journey of Toi moko. Ancestral remains are compelling objects that define Māori cultural identity. By their affiliation to identity, territory, genealogy, mana or even tino rangatiratanga, Toi moko have a key place in Māori heritage. Toi moko not only tell compelling stories of events that are part of New Zealand's national heritage but also, as I argue in this thesis, are related to the French colonial past. This study involved the gathering 
of data from archives, libraries and museums records that have never been examined before. These records provided a better understanding of the journey undergone by the deceased and provided more substance by adding in Māori knowledge associated with the historical records. Their journey shaped their meaning and status as heritage until their final return. Testimonies from explorers and scientists also helped everyone involved in negotiations to understand the origins of European imagery about Māori cultural identity. The judgement, through religious influences, of what is called 'savagery' is at odds with legitimate cultural practices like pakipaki māhunga.

For example, the Toi moko of the Maritime Museum in Paris is described in the archives as one of the Toi moko donated by René Primevère Lesson after his trip aboard the Coquille. In his writing Lesson describes a donation made to Rochefort museum. In 1928, this Toi moko has been transferred to the Natural History Museum of La Rochelle. And finally, this dried, preserved head was transferred from La Rochelle to Paris but no date has been referred in the acquisition book. Also, the Montpellier collection is still under investigation. Michel Van Praët developed this case during our meeting. Furthermore, it appears that official procedure is not always respected. Michel Van Praët revealed that the process of deaccessioning before the transfer did not happen systematically. Because ancestral remains are controversial artefacts, these decisions may appear today to have been carried out without taking into account all the legal process.

This is why throughout the process of negotiation, nobody wanted to face the fact that most of the Toi moko have been donated to the state. Legally, no collection donated to the state can be deaccessioned. Repatriation, therefore, seemed impossible and it is understandable that museum staff in France or in New Zealand are not focusing only on repatriation. Because of their tight schedules and diverse activities, museums do not want to take too much time for repatriation. They are simply not built to return objects. Their purpose is to exhibit objects taken away from their original environments in order to transmit knowledge and heritage. Museums are an essential part of the Western educational system. Thanks to museums, every student can get an idea of what they are studying in class about art and natural or human history.

The exchanges of Toi moko during the Musket Wars (1806-1845) have so far generated little scientific enquiry. This episode, however, illustrates the relationships shaped between explorers and natives from the first contacts. French scientific explorations have greatly 
contributed to the acquisition of Toi moko and other Māori ethnographic collections. Most of the heads that have been returned so far have been brought back to France by scientific figures such as Jules Sébastien César Dumont d’Urville or René Primevère Lesson. It is still difficult to specify with precision the extent of the participation of French vessels in this type of transaction. We can, however, say that not only scientists and explorers played a role in the trade, but also settlers and whalers have been extensively interested in acquiring Toi moko too.

Repatriation is, therefore, deeply inserted in the postcolonial problematic. This statement raises questions about the suppression of memory and the silence that we witness regarding French imperialism and colonial actions. When the notion of postcolonialism or decolonisation is suggested within Western societies, speeches rapidly centre on immigration or integration and leave no place for cultural richness and differences. The story of the journeys of the Toi moko inside the French collections had to be told in order to get a complete understanding of Toi moko themselves and how they play a role in the analysis of the place of human remains inside museums.

In chapters Three and Four, I discussed the mutual influences that repatriation practice has produced both in France and in New Zealand. Te Papa wanted to use the opportunity to develop Māori voices in international museums like in Rouen or Paris, and France wanted to get a better understanding of Indigenous cultural identity today. Racial discrimination is still felt by Māori in New Zealand and museums are no exception. As a national museum, Te Papa is seen more as an experimental system model than a realistic reflection of New Zealand society.

However, Te Papa seems the appropriate institution to welcome KARP. Te Papa has been created in order to develop modern practices in terms of scientific narratives and preservation with the communities of origin. Since 2003, repatriation has been a key mission that has defined the biculturalism developed in the national museum. However, KARP is not the heart of the museum. The decision to create Te Papa is not affiliated to the repatriation practice itself. Te Papa is then the platform used for the development of such a task by using the Māori values already applied in the institution. KARP was invited to be at Te Papa five years after the opening of the museum. Repatriation is one activity that defines biculturalism, among others. That is why the collaboration between NSTP, the mātauranga Māori team, hosts, events, marae activities, KARP and kaitiaki is necessary to apply bicultural concepts that are 
still evolving. Te Papa is constantly rethinking the better application of such a versatile and not entirely established system. Te Papa as a national museum seems to have sufficient resources to apply such a task, but it is definitely not the case for every museum in New Zealand. Furthermore, the bicultural system is not commonly shared in New Zealand. Every museum, according to its importance in terms of staff, resources or political approach towards such a concept will define their actions as bicultural or not differently. Therefore, Te Papa is seen as an experimental attempt to apply inclusion and equality between communities that define national identity. That is the reason why the bicultural system also reflects multicultural approaches in its application. The period of revitalisation of Māori cultural identity may have resulted in the creation of several organisations whose main mission is to protect Indigenous intellectual property against stigma and overuse of Indigenous arts and expression. The values set out in the programme encompass the importance to protect and include Māori values that define both tangible and intangible heritages.

Despite the differences of policies internationally, the role of KARP is then to adapt and discuss how to succeed in the negotiations. Because KARP is dealing with so many different institutions and different policies, the programme also has a diplomatic responsibility to introduce current Māori claims and work out how to apply tikanga not only in museums but also in everyday situations, using the museums environment as a door to te ao Māori. KARP, for example, has the responsibility to answer questions raised by foreign audiences but they are not defined as a political Māori authority like iwi or Te Puni Kōkiri. KARP needs to manage iwi requirements and political conditions in order to carry out this mission. This multiplicity of opinions that emerge from the dialogue complicate the practice of return and its interpretation. Although the return of ancestors is approved by all tribal authorities, each of them has, nevertheless, its own appreciation of the process required to accomplish it. The relationships between ministry and iwi, museum and marae, kaitiaki and tangata whenua and the contributions of innovation and tradition are at the centre of all discussions. Despite the tensions between Māori and the state, the various points discussed above shed light on the motivations that may have led to the creation of the KARP programme.

Whakapapa and tapu are fundamental principles in the continuity of the Māori arts determined here through tā moko and the method of drying heads. There are, consequently, connections between the repatriation of ancestors and the emancipation of art expression such as tā moko. The creation of collectives like Te Uhi a Mataora, the popularity of tā moko, its 
intellectual/cultural property rights with the WAI $262^{15}$ and its importance for historical knowledge of Indigenous culture contribute to a desire to put in place a protective policy. The contribution of the research carried out by the tohunga tā moko into the reading of tattoos and their authenticity is endorsed by the programme and remains crucial to KARP's research. Some international interpretations of tā moko worldwide are not associated with intellectual property rights. Māori heads are, for the most part, decorated with this type of tattoo, and knowledge of the tā moko technique is then necessary for a detailed study of the traffic. In some cases, these investigations can also be useful in obtaining information about the deceased. A common database that combines research from Western archives, Māori concepts and descriptions of artistic technics like tā moko describes the value given to Toi moko and their scientific narratives today.

Chapter Five identified and presented a number of current challenges in the postcolonial museum environment where repatriation is progressively defined as a museum practice, both for French and New Zealand museum professionals. The breakdown of each challenge into six different themes has echoed the multidisciplinary dimension of these operations to return remains, and has helped with my understanding of the underlying conceptions of museums and led to mutual understanding for both parties. Chapter Five discussed expectations in terms of post-repatriation changes and outcomes. Politics is inherent in the cultural dimension of the process today. Protocols and legitimate procedures have had to be followed in order to respect the law and ethical principles of each state. This procedure is then constantly evolving according to the current precepts, claims and intentions that contextualise the repatriation programme at a certain time. As we have seen all along with this thesis research, the repatriation procedure is not only characterised by the loss of Māori heads, but is also an opportunity to adapt personal and general assumptions with others to reach mutual understanding.

I am not saying that Indigenous perspectives should be the only ones to follow today. Although for several decades a decolonised museology has been discussed and theorised, repatriation remains is an opportunity to put some of these precepts into practice. Negotiations for return are the opportunity to bring together different perspectives that reflect the history and use of human remains in museum collections. A holistic perspective on every object would help to understand its scientific and cultural heritage. For example, KARP let the

\footnotetext{
${ }^{15}$ The Wai 262 claim was lodged with the Waitangi Tribunal in 1991 and addresses issues related to the intellectual and cultural property rights of Toi Māori, Māori arts.
} 
French government know that Māori authorities are against the use of tūpuna in scientific research. After that, Te Papa and KARP became aware that Toi moko were still in French museums. While fearing they would lose the object, French scientists rapidly analysed and kept a file on research made on Toi moko before the repatriation. These perspectives contribute to the controversial definition of Toi moko in French museums. Especially by making essentially unilateral choices. Feeling that more time was needed to use Toi moko in France, making the decision to use the real Toi moko for a documentary film and saying publicly that was a copy so as to respect Indigenous beliefs and organising open days to say goodbye to a Toi moko have all been actions taken by museums in France just before repatriation ceremonies. These actions indicate a lack of experience and a desire to keep control over a discussion which, theoretically, is designed to be equal. The different levels of authority involved in repatriation complicated discussions and created conflicts of interest among repatriation practitioners. This association of cultural and political spheres in New Zealand and in France necessitates cultural diplomacy and ongoing discussions and debates among museums and repatriation practitioners.

The lack of knowledge and communication between museums on the topic has clearly been an obstacle to getting clear and rapid answers to repatriation request. This has led to engagement with individual museums with or without support among each other. The interrupted ceremony in 2007 is the result of this internal struggle between museums, local authorities and ministries. At each point of the negotiation there were debates and opposition. A national policy would help to maintain one path without having to rely only on temporary administration provided by, for example, ministers, senators or curators. Issues surrounding objects collected during the colonial period, the collecting modes of museums, human remains made for funeral purposes and later for trade, the legal hole on human remains in collections, the effect of associated ceremonies on the secular principle of French public institutions, and finally, the definition of Toi moko themselves in French collections have all been subject to alterations and debates. If personal and collective appreciations are so different, the use (in science or in exhibitions) of human remains in museums will remain unsuccessful without the foundation of some common ground. That is the reason why I have considered the repatriation process through the relationships that it generates.

In this thesis, the case study of Toi moko is not the absolute ideal for international collaborations, but I think the process I have analysed really helps to rebalance the power between museums and communities of origin and opens a space to insert Indigenous voices 
inside Western institutions. Western museums cannot evolve anymore without engaging with Indigenous perspectives. This synthesis of different multidisciplinary fields of research has made it possible, for example, to discover the evolution of relations between French and Māori. At Te Papa, I had the chance to establish a continuous collaboration with repatriation researchers. Becoming the first foreign repatriation intern at KARP was challenging on several levels, such as basic communication during the first weeks, but this experience more importantly was the occasion to learn from indigenous perspectives how they saw the process of return. Being part of KARP has been the opportunity to learn not only about repatriation debates but the richness of Māori cultural identity. The diversity of experiences during my time at Te Papa such as provenance research, translation, ceremonies, taonga pūoro practice, waiata practice, meetings or even diplomatic visits, enabled me to understand the transmission of Māori knowledge about tangible and intangible heritage and how the repatriation process is a means to introduce Māori cultural claims internationally.

The repatriation of objects is not a primary activity of museums and has been considered political and experimental. It is, today, a tool for the public and museum staff to use in their work on conceptualism and Western imagery of foreign communities. Despite the highly knowledgeable status of the curator, it is frequent to see museum staff working with specialists of natural spaces or species, for example, and other experts, such as anthropologists, towards the creation of exhibitions. Repatriation is a result of the postcolonial model of a museum that invites more contact between Western institutions and communities of origin. Having analysed this issue case by case, I am certain that French authorities need to create a vade-mecum or a national policy to advise on how to reply to repatriation requests. Giving the same answer to every demand is not the solution but museums need to have clear advice from government and experienced repatriation practitioners on how to give appropriate responses.

This study has provided an insight into the repatriation practice beyond that developed in the literature. By using a pragmatic and in-depth theoretical approach, my case study has analysed over a decade the changes in repatriation and its outcomes, contrasting representation and appreciation by comparing museums and practitioners and the countries in which they are located, the incorporation of Māori concepts and knowledge embodied in the definition of repatriation in New Zealand and how its application has influenced French authorities in their way of returning Toi moko. Furthermore, my personal involvement in the process of learning and negotiation as a go-between for French and New Zealand authorities has enabled me to 
observe and record some of the difficulties expressed by several negotiators. The findings of the thesis add to my understanding of "liberating cultures" developed by Kreps (2003) by exploring cross-cultural perspectives on what a museum is, and how repatriation can be a tool to shape international discussions on the growing recognition of Indigenous models of cultural heritage and their inputs in conventional museum practice. Museum institutions located in this study in France and New Zealand, shared common traditional conceptions and definitions. Before the establishment of Te Papa, the Dominion Museum was influenced by Eurocentric models applied traditionally. The conventional role of museums was then applied in both countries. A modern, critical theory of museology is expressed here through the creation and implementation of a distinct administrative system that, through repatriation, has elevated cultural dynamism and problematised museum practices and their assumptions. In her $\mathrm{PhD}$ thesis, Michelle Horwood focused on the engagement of Indigenous communities with remote museums and curating models which expressed the idea of long-term relationships. In terms of museum practice, relationships complicated the curating approach of objects collected and reflected a modern collaborative opportunity offered by globalisation and modern ways of communication.

It takes time to build a relationship and gain respect and trust from individuals and communities (for which a doctoral research timeframe is far too short) and outcomes may not be realised for years. It is therefore essential to allow time for consultation with all stakeholders, who need to be able to weigh up the benefits of participating (or not) and fully understand the processes and expectations involved. (Horwood 2014, 276)

Finally, more research is still needed on Toi moko that have already returned to Wellington in order to determine their final resting places. Most of the Māori preserved heads known by French establishments are already inside Te Papa's wāhi tapu. However, there remains a possibility of finding a certain number of heads in private spheres.

After all these years of contact, negotiation and accomplishment, there are still many debates to be held and recommendations to make in both countries in order to maintain or elevate this research. I hope to follow this up in subsequent publications and presentations.

As a repatriation researcher and intermediary between these two countries, I have had the opportunity to learn and then have had to quickly turn around and teach French museums about Māori claims. This study has given me a chance to contribute personally to the 
diplomatic and cultural projects undertaken in the return of Toi moko to their land of origin. I believe this has had some effect on the mutual influence of both countries through the engagement of their museums in repatriation.

French museums needed to take part in the process of repatriation in order to clarify their role in modern international politics concerning colonial collections, and to engage with foreign authorities. Repatriation is one opportunity, among others, to collaborate and stop hiding behind old principles that, today, represent only a minority of citizens of Western countries. The results of this are not simply 'ethical' and temporary. The research carried out postrepatriation and the ongoing relationships established between international researchers make it possible to understand that France has been part of the trade of Māori human remains. Multiculturalism is far more influential today than individual French centrism. The balance of power between museums in former colonial powers and museums in colonised countries is evening out as populations grow closer through communications and networks, as illustrated by the ways in which French and Māori engaged in ceremonies and post-repatriation projects.

As a final outcome of this thesis, I wish to work towards creating sustainable relationships between French and Māori museum professionals in future. Collaboration between the Māori community and French institutions are only in their preliminary stages. I hope I have contributed to the introduction of these new mutual influences and would like to be able to develop them further. 


\section{Glossary}

Definitions below are drawn from the following references:

Barlow, Cleve. (2001) Tikanga whakaaro key concepts in Māori culture. Oxford: Oxford University Press.

Mead, Hirini Moko. (2003) Tikanga Māori living by Māori values. Wellington: Huia Publishers.

Ryan, Peter Michael. (2008) The Raupo Dictionary of Modern Māori, Māori-English. Hong Kong: Raupo.

Williams Herbert W. (1957) A Dictionary of the Maori Language. Sixth ed., Wellington:

Government Printer.

Maori dictionary online website: www.maoridictionary.com (accessed 30 June 2021).
Ahurewa :
Sacred places for rituals.
Aotearoa :
New Zealand. Translated as "land of the long white cloud".
Ariki :
High chiefs.
Aroha :
Love, respect, compassion.
Atua :
Gods or Demons. Ancestor with continuing influence.
Awe :
Strength, power, influence.
Haere ra :
Goodbye (said to someone leaving). E noho rā (said to someone staying).
Hahunga :
Ceremony for uplifting bones - includes the actual disinterment, the scraping of the bones and ritual practices before moving them to a final resting place.
Haka : (Verb) to dance, perform the haka, perform. (noun) performance of the haka, posture dance-vigorous dances with actions and rhythmically shouted words. A general term for several types of such dances.
Haka pōwhiri :
Ceremonial dance performed to welcome visitors. The performers sometimes wave leaves as a symbol of death. 
Hāngi :

Hapū :

Hariru :

Hawaiki :

Hei tiki :

Hei mahoe :

Hongi :

Hui ā rohe :

Ihi :

Iwi :

Iwikore :

Kai :

Kai- :

Kaihautū :

Kāinga :

Kaitiaki :

Kaitohutohu Kōiwi Tangata :
Earth oven - earth oven to cook food with steam and heat from heated stones.

(Noun) Sub-tribal group.

Handshake.

Ancient homeland of Māori and Polynesians.

Pendant, greenstone neck ornament representing ancestors.

Term that may define the mallet that hit the uhi during the process of tā moko.

(Noun) pressing noses in greeting.

Meeting on sites. KARP meets with iwi to hear their views and opinions on issues and future operations.

(Noun) essential force, excitement, thrill, power, charm, personal magnetism - psychic force as opposed to spiritual power (mana).

(Noun) extended kinship group, tribe, nation, people, nationality, race - often refers to a large group of people descended from a common ancestor and associated with a distinct territory.

Be without strength, feeble, weak, listless.

Food.

Prefix added to verbs which express some kind of action to form nouns denoting a human agent (i.e. the person doing the action),

e.g. kaikōrero (speaker), kaitiaki (guardian).

(Noun) person who gives the time for the paddlers in a canoe, fugleman. In other contexts, a term that refers to a leader. At Te Papa, the kaihautū is the leader of the Māori activities of the museum (in 2011-2012 Michelle Hippolite occupied this position. Arapata Hakiwai is the current kaihautū.

(Noun) home, address, residence, village, settlement, habitation, habitat, dwelling. Te Iwi Kainga o Te Papa is the name of the Haka group of Te Papa.

Guard, custodian, guardian, caregiver, keeper.

Coordinator of KARP, position occupied by Te Arikirangi Mamaku (2009-today). 
Kaiwhakahaere Kaupapa Putere : Manager of KARP, position occupied by Te Herekiekie Herewini (2007-today).

Ka Mate :

Kapa haka :

Karakia :

Karanga Aotearoa :

Kawa :

Moko kauae :

Kaumatua :

Kaupapa :

Koha :

Kōiwi tangata / Koimi tangata:

Kūmara :

Mana :

\section{Mana tūpuna :}

Mana wāhine :

Manaakitanga :

Manuhiri :
Title of the most famous haka. Performed by the All Blacks, this haka was created by Te Rauparaha from Ngāti Toarangatira (Ngāti Toa).

Haka group, Māori cultural group, Māori performing group.

(Noun) incantation, ritual chant, chant, intoned incantation, charm, spell.

Name of the Repatriation Programme. Translated as "The beckoning call to return home". Name chosen by Te Ikanui Kapa (Ngāti Kuri), Māori language expert and esteemed elder.

Protocol.

Tattoo on the shin.

Adult, elderly man or woman, elder, a person with status within the whānau, hapū, iwi.

Topic, policy, plan, scheme, proposal, subject, programme, theme, initiative.

Gift, present, offering, donation, contribution.

Māori skeletal remains. Human bones.

Sweet potatoes.

Prestige, authority, control, power, influence, status, spiritual power, charisma. Barlow described the concept as the power of gods (mana atua), power of ancestors (mana tūpuna) and the power of man (mana tangata).

The power of the ancestors as passed down from generation to generation

Power of woman that emphasises the importance of woman in Māori society.

Hospitality, kindness, generosity, support - the process of showing respect, generosity and care for others.

Visitors, guests during pōwhiri including repatriation ceremony. 
Mānuka :

Māori :

Māoritanga :

Marae :

Marae ātea :

Matariki :

Mātauranga :

Mauri

Mere :

Moa :

Moko :

Mokomokai :

Moriori :

Mōteatea :

Noa :

Ngutu :

Pā :

Pākehā :

Paki paki or Popo :

Pakipaki māhunga
Leptospermum scoparium - a common native scrub bush. Sometimes a mānuka stick is used to let the nose keep its formal shape during the pakipaki māhunga.

Indigenous people of Aotearoa New Zealand.

A term used to describe those aspects that collectively make up Māori identity and culture.

Traditional Māori ceremonial and community centre.

Courtyard - the open area in front of the wharenui, where formal greetings and discussions take place and issues debated. Space dedicated to Tūmatauenga, god of war.

Māori New Year.

Māori knowledge, traditional and contemporary.

Life force, life-giving essence.

A short, flat weapon of stone, often of greenstone.

Dinornithidae, large extinct flightless birds of nine subspecies endemic to Aotearoa New Zealand.

Tattoo.

Term designating dried and tattooed heads.

Etymologically this term refers to the art of tattooing (moko) on captives (mokai). It was used after the arrival of Europeans to designate all the dried and tattooed heads from New Zealand.

Indigenous people of Rēkohu Chatham Islands.

Lament, traditional chant, sung poetry-a general term for songs sung in traditional mode.

Free from tapu.

Tattooed lines on lips.

Fortified village.

Foreigner, European, exotic — introduced from or originating in a foreign country.

To drain, dry. Part of the process of drying heads.

Process of drying heads. 
Pāpātea :

Patu :

Patu onewa:

Piupiu :

Pōngiangia :

Poi

Poupou :

Pou Rangahau Rautaki Kōiwi:

Pounamu :

Pōwhiri :

Rangatira :

Rape :

Rarohenga :

Taiaha :

Tangata Tiriti :

Tangata whenua :

Tangihanga :

Taonga :

Taonga tuku iho :
Ordinary heads, with no tattoo.

Short club.

Short club made of dark grey stone.

Waist-to-knees garment made of flax-has a wide waistband and is used in modern times for kapa haka performances or ceremonies such as domestic repatriation and sometimes international repatriation as carried out at MQB-JC.

Motifs tattooed on nostrils.

A light ball on a string of varying length which is swung or twirled rhythmically to sung accompaniment. Traditionally the ball was made of raupō leaves.

Carved ancestral wall post figure that represent an ancestor.

Researcher of the repatriation programme. Position currently occupied by Amber Aranui.

Greenstone, nephrite, jade.

Welcoming ceremony.

Chief.

Circular motifs tattooed on buttocks or cheeks.

The underworld. The place where the spirits of the dead go.

Long wooden weapon — of hard wood with one end carved.

The people of the Treaty, New Zealanders of non-Māori origin.

People of the land, local people, hosts, IndigenousIndigenous people.

Funeral Process.

Treasures.

Highly prized object that has been handed down from the ancestors. 
Tapu :

Te ao Māori

Tekoteko :

Te Papa Tongarewa :

Te reo :

Tikanga :

Tino rangatiratanga :

Tūpuna/tīpuna :

Tiriti :

Tohunga :

Tohunga tā moko :

Tohunga whakairo :

Toi moko :

Tūpāpaku :

Turangawaewae :

Uhi :

Upoko :

Urupā :

Utu :

Wāhi tapu :

Waiata :

Wairua :

Waka :
Sacred, prohibited, restricted.

Māori world.

Carved figure on the gable of a meeting house, figurehead.

Māori name of the Museum of New Zealand. Literally translates as "container of treasures". A fuller interpretation is 'our container of treasured things and people that spring from mother earth here in New Zealand' (tepapa.govt.nz, accessed 11/05/2020).

Māori language.

Customary system of values, beliefs and practices.

Self-determination, sovereignty.

Ancestors.

Treaty. Te Tiriti o Waitangi, the Treaty of Waitangi.

Skilled person, experts, priests, healer.

Expert in the art of moko (tattoo).

Master carver.

Māori preserved tattooed head.

Deceased person's body or corpse.

Place of belonging, place to stand.

Moko chisel, tool for tattooing.

Head. Upoko kōhue translates as 'boiled head'.

Burial place, cemetery.

Reciprocity, revenge.

Sacred place

Chant, song.

Spirit, soul.

Canoe, vehicle. 
Waka taua :

Wānanga :

Wero

Whaikorero :

Whakairo :

Whakapapa :

Whānau :

Whānaungatanga :

Whare :

Wharekai :

Wharenui :

Whare taonga :

Whare wānanga :

Whenua :
War canoe.

Seminar, meeting, workshop, conference.

To pierce, spear, challenge.

Oratory, oration, formal speech.

Carving.

Genealogy.

Family.

Relationship.

House.

Dining hall.

Meeting house.

Museum.

Place of higher learning, university.

Hearth, land, placenta. 


\section{Bibliography}

A. Primary sources:

1. Archival documents

2. Unpublished museum documents

3. Websites

4. Newspapers and other online sources

5. Interviews

B. Secondary sources, including books, book chapters, journal articles, theses and other published material.

\section{A. Primary Sources}

\section{Archival documents}

\section{At the museum of Rouen:}

Museum of Rouen, Acquisition Book- July 1875, Donation of Mr. Drouet

Museum of Rouen, Description file Ref.019491 : Tête maorie tatouée, Inv. n4/05/2010.

\section{At the Archives centre in Paris:}

Birth Act:

Naissances, 1873-1882, 8e arr., Drouet. D1M976

Naissances, 1860-1873, $8^{\mathrm{e}}$ Arr., Drouet. D1M919

Death Act:

Décès, 1873-1882, 8e arr., Drouet, D1M9 812

Décès, 1883-1892, 8.arr., Drouet, D1M9 863

Décès, 1893-1902, 8e arr., Drouet, D1M9 817

Décès, $8^{\mathrm{e}}$ arr., 12/02/1882. V4E 3470 
Décès, 8e arr., 20/11/1861. V4E 880

$\underline{\text { Wedding Act: }}$

Mariages, 1860-1872, 8e arr., drouet, D1M9 419

Mariages, 1873-1882, 8e arr., d.D1M9 461

Mariages, 1883-1892, 8e arr., drouet. D1M9 503

$\underline{\text { Map of Paris : }}$

8e arr., Champs Elysées, 29e feuille, PP/11754/A

8e arr., Champs Elysées, 29e feuille, PP/11755/B

8e arr., Faubourg du Roule; 30e feuille, PP/11902/B, I

8e arr., Faubourg du Roule, 30e feuille, PP/11902/B, II and III.

General Atlas of Paris and its suburb; descriptions of the 20 arrondissements. [Atlas 156].

Election List:

Political Election List (1848-1939) area of "Faubourg du Roule", $18^{\text {th }}$ June 1871:[D.1M2 180]

Jean Pierre Elme Leduc:

Birth Act: V3E/ N 1363

Death Act: V4E 880

\section{Archives in Montpellier:}

Catalogue général du Musée d'Anatomie, $\mathrm{n}^{\circ} 1$, Armoires 1 à 14 et armoire nº 16 .

Register 1MED47- “Order of Appointment”- 14 March 1832.

Register 1MED48- “Order of the day”- 19 November 1852.

Dulieu, Louis (1988) La médecine à Montpellier, Les Presses Universelles, Vol.4, 1st part, Ancient Fund collection of the library of the Conservatory. 


\section{Unpublished museum documents}

Annual report of the Museum of New Zealand Te Papa Tongarewa, Museum of New Zealand Te Papa Tongarewa, Wellington, 2008-2009.

Annual report of the Museum of New Zealand Te Papa Tongarewa, Museum of New Zealand Te Papa Tongarewa, Wellington, 2009-2010.

Annual report of the Museum of New Zealand Te Papa Tongarewa, Museum of New Zealand Te Papa Tongarewa, Wellington, 2011-2012.

Annual report of the Museum of New Zealand Te Papa Tongarewa, Museum of New Zealand Te Papa Tongarewa, Wellington, 2012-2013.

International Symposium (2008) "Des collections anatomiques aux objets de culte :

Conservation et exposition des restes humains dans les musées”, musée du quai Branly, 22 et 23 February, 2008.

Karanga Aotearoa Repatriation Programme (2009a) “Training Booklet: conservation workshop", Museum of New Zealand Te Papa Tongarewa, Wellington.

Karanga Aotearoa Repatriation Programme (2009b) “Te Pānui o Karanga Aotearoa, Issue no.1” Newsletter, June/Piripi 2009, Museum of New Zealand Te Papa Tongarewa, Wellington.

Karanga Aotearoa Repatriation Programme (2010a) “Te Pānui o Karanga Aotearoa, Issue no.2", Newsletter, February/Hui Tanguru 2010, Museum of New Zealand Te Papa Tongarewa, Wellington.

Karanga Aotearoa Repatriation Programme (2010b) “Te Pānui o Karanga Aotearoa, Issue no.3" Newsletter, October/Whiringa ā nuku 2010, Museum of New Zealand Te Papa Tongarewa, Wellington.

Karanga Aotearoa Repatriation Programme (2011) “Te Pānui o Karanga Aotearoa, Issue no.4” Newsletter, July/Hongogoi 2011, Museum of New Zealand Te Papa Tongarewa, Wellington.

Karanga Aotearoa Repatriation Programme (2012a) "Ngati Tuwharetoa report", hui à rohe at Waitetoko Marae, 13 October 2012, Te Rangiita Taupōnui a Tuia. 
Karanga Aotearoa Repatriation Programme (2012b) “Te Tau Ihu o Te Waka Whakatū Marae Report", Uhi a rohe 29 October 2012, Nelson.

Karanga Aotearoa Repatriation Programme (2012c) “Te Tau Ihu o Te waka Omako Marae Report”, Uhi a rohe 30 October 2012, Blenheim.

Karanga Aotearoa Repatriation Programme (2012d) "Drafting a new Repatriation Strategy for Kōiwi/Koimi Tangata and Toi moko 1 July 2013 to 30 June 2016”, Discussion Paper, Unpublished document, April 2012.

Karanga Aotearoa Repatriation Programme (2013) “Te Pānui o Karanga Aotearoa, Issue no.5” Newsletter, summer/Raumati 2013, Museum of New Zealand Te Papa Tongarewa, Wellington.

Musée du quai Branly, 2011, "Les têtes mokomokai Maori du Musée du quai Branly", unpublished report.

Museum of New Zealand Te Papa Tongarewa Statement of Intent 2012/13, 2013/14, 2014/15, p.6 online:

http://www.tepapa.govt.nz/SiteCollectionDocuments/AboutTePapa/LegislationAccountabi lity/Te.Papa.Statement.Of.Intent.2012-2015.pdf (accessed June 2015)

Smith, Nicola Kiri. (2011) “Uhi and ngarahu”, Unpublished report, Karanga Aotearoa Repatriation Programme, Wellington.Unpublished Research report, Montpellier: Têtes maories by Michel Van Praët, 30 November 2011Unpublished report, Decommissioning File, 17 January 2012 34-Montpellier, University of Montpellier 1.

\section{Websites}

Académie des Sciences (1837) Annales des Sciences Naturelles et dans les Comptes rendus hebdomadaires des séances de l'Académie des Sciences, Volume 4, URL: https://gallica.bnf.fr/ark:/12148/bpt6k29634/f7.item\# , (accessed 13 July 2016)

Administrative Court of Douai, Formation plénière, 24/07/2008, 08DA00405 publié au recueil Lebon. URL : https://www.legifrance.gouv.fr/ceta/id/CETATEXT000019649277/ (accessed 12 November 2020). 
Blanchard, Pascal. (2018) "Pourquoi la France est incapable d'avoir un Musée de la colonisation ?", Youtube video, 25 :23, Théâtre du Rond-Point, 24 january 2018, https://www.youtube.com/watch?v=a6CRIWRhwh8 (accessed 17 February 2019)

Compte rendu analytique officiel du 29 juin 2009 de la proposition de loi autorisant la restitution des têtes maories : http://www.senat.fr/cra/s20090629/s20090629_4.html (accessed 10 October 2018).

Map of France with cities locations where institutions returned Toi moko between 2011-2012: http://www.cartesfrance.fr/carte-france-ville/carte-france-villes.html (accessed 2 December 2010).

Esra Akcan, Souleymane Bachir Diagne, Jonathan Fine \& Cécile Fromont (19 October 2020) "Repatriation of Museum objects", Webinar from Cornell University, New York, https://einaudi.cornell.edu/discover/news/watch-repatriation-museum-objects-webinarrecording (accessed 19 october 2020)

ICOM, Code of Ethics, section 6.3. Restitution des biens culturels (accessed 15 February 2021).

ICOM (2020), "What definition do museums need? Proceedings of the ICOM Committee's day", March 2020, Paris. (accessed 15 February, 2021) (https://www.icommusees.fr/sites/default/files/202006/Whatdefinition.pdf?fbclid=IwAR387OrnXA8iRE74h8ub_Y829qyba_uJMEFtV7vgGn UBO3iSqlla1Cpm_ZI) (accessed 15 February, 2021)

International Research Institute For Māori and Indigenous Education (IRI) (1997), "Cultural And Intellectual Property Rights, Economics, Politics \& Colonisation”, Auckland University (accessed 27 June 2018).

L'Histoire de Paris par ses plans, https://www.laboiteverte.fr/historique-des-plans-de-paris/ (accessed 12 november 2018)

Moorfield, John C. Te Aka Online Māori Dictionary (www.maoridictionary.co.nz)

Morin-Desailly, Catherine. (2009) "rapport de la proposition de loi autorisant la restitution par la France des têtes maories à la Nouvelle Zélande", session ordinaire 2009, Sénat, Paris. (Accessed 10 october 2018). 
Musée de l'Homme, (2012) La question de la restitution des restes humains, Restitution des têtes maories, tout public 2/3, 17:32, July 252016,14 'min, https://www.youtube.com/watch?v=mFDG4qyd1kQ\&t=460s (accessed 14 August 2017).

Ministry for Culture and Heritage, 'The Musket Wars', URL: https://nzhistory.govt.nz/war/new-zealands-19th-century-wars/the-musket-wars, (accessed 13 may 2018)

Ministry for Culture and Heritage, 'Te Maori exhibition opens in New York', URL: https://nzhistory.govt.nz/te-maori-exhibition-opens-in-new-york (accessed 8 November 2015)

Froment, Alain. 2012. "Restitution des têtes maories, l'apport des restes humains à la connaissance scientifique”, MNHN, DICAP, Pôle Multimédia, Conference 21 January 2012, Paris (accessed 15 January 2019).

National Maritime Museum, "Un voyage de découvertes au siècle des Lumières-Dossiers de visite", exhibition catalogue, Paris, 2008 : http://www.museemarine.fr/sites/default/files/un_voyage_de_decouvertes_secondaire_site.pdf (accessed 30 May 2018)

Richert, Philippe. (2002) Rapport fait au nom de la commission des Affaires culturelles, sur la proposition de loi de Nicolas About autorisant la restitution par la France de la dépouille mortelle de Saartje Baartman à l"Afrique de Sud, Sénat, session ordinaire 2001-2002, Sénat, Paris (accessed 8 October 2018).

Rouen Museum website, "l'affaire de la tête maorie de Rouen”, URL: museumderouen.fr, (accessed 12 May 2016).

Ryan, Peter Michael. (2008) The Raupo dictionary of Modern Māori, MāoriEnglish, éd. Raupo, Hong Kong.

Senat website (2010) Proposition de loi visant à autoriser la restitution par la France des têtes maories. URL : https://www.senat.fr/rap/108-482/108-482_mono.html (accessed 14 November 2018).

Sébastien Minchin, 'La fabuleuse histoire de la tête Maorie de Rouen', conférence Université de Toutes les cultures, November 24, 2014, 7'min. https://webtv.univ-rouen.fr/videos/utlc- 
la-fabuleuse-histoire-de-la-tete-maorie-du-museum-de-rouen-par-sebastien-minchindirecteur-du-museum-dhistoire-naturelle-de-rouen/\#info (accessed the 22 May 2015).

\section{Newspapers and other online sources:}

“Air NZ stands by tattoo policy”, In New Zealand Herald, 7 June, 2013.

http://www.nzherald.co.nz/nz/news/article.cfm?c_id=1\&objectid=10889054 (accessed 7 June 2013)

Auguste Bérard biography, Pôle Patrimoine scientifique de l'Université Montpellier 2:

http://www.collections.univ-montp2.fr/com-collector-collections/les-grands-noms-delum2/item/6-grands-noms/5805-01011822 (accessed 18 July 2015)

TeWhakaminengaoKapiti,2012-2013, p.4 :

(http://www.kapiticoast.govt.nz/Documents/NewslettersAndPeriodicals/te- 
whakaminenga/2012/TWoK-quarterly-newsletter-Oct-Dec2012.pdf) (accessed 12 September 2014)

“Cheeky French steal moko”, Life \& Style, www.stuff.co.nz, 2007. (accessed January 2012) http://www.nzhistory.net.nz/politics/treaty/treaty-timeline/treaty-events-1950 (accessed 18 April 2018)

http://www.nzonscreen.com/title/tangi-for-te-arikinui-dame-te-atairangikaahu-2006 (accessed June 2016)

http://www.tepapa.govt.nz/AboutUs/history/Pages/Ournamesandleadersovertime.aspx\#tepapa kaihautu (accessed 26 May 2019)

http://www.tepapa.govt.nz/AboutUs/Repatriation/Pages/HuiaRohe.aspx (accessed 26 May 2019)

http://www.tepapa.govt.nz/Education/OnlineResources/Archive/Moko/artistbios/pages/julieki pa.aspx (accessed 26 May 2019)

http://www.tepapa.govt.nz/Education/OnlineResources/Archive/Moko/Pages/TeUhi.aspx (accessed 12 May 2019)

http://www.tepapa.govt.nz/ResearchAtTePapa/Research/TaongaMaori/Pages/overview.aspx (accessed 12 May 2019)

http://www.tepapa.govt.nz/whatson/exhibitions/pages/themarae.aspx (accessed 12 May 2019) http:/maori.rouen.fr Blog for supporting the repatriation of the Toi moko from Rouen Natural History Museum (accessed 15 January 2012)

http:/www.legifrance.gouv.fr (accessed 8 February 2012)

http:/www.tepapa.govt.nz/repatriation program (accessed 2 May 2009)

http:/ www.laboitverte.fr/historique-des-plans-de-paris (accessed 12 December 2011)

"Te Māori" exhibition inauguration at the United States: http://www.nzhistory.net.nz/temaori-exhibition-of-traditional-maori-art-opens-at-the-metropolitan-museum-of-art-in-newyork (accessed 10 July 2018) 
Video of the Haka Flashmob realised at the exhibition « Māori leurs trésors ont une âme » occasion in the subway at Paris. The title is Flashmob: Māori in the subway: https://www.youtube.com/watch?v=q2xy-zmZxhA (accessed 16 November 2011)

Video of the opening ceremony for George Nuku's exhibition Bottled Ocean 2115: https://www.dailymotion.com/video/x2qu1cw (accessed 5 March 2019)

Ministry of Justice, New Zealand website, Mana and Tapu, publications archived, 2001. http://www.justice.govt.nz/publications/publications-archived/2001/he-hinatore-ki-te-aoMāori-a-glimpse-into-the-Māori-world/part-1-traditional-Māori-concepts/mana-and-tapu (accessed 15 May 2009)

Mcpherson, Liz. (2013) New Zealand Statistics, Te Kupenga, key facts. www.stats.govt.nz. Mcpherson, Liz. (2013) Steady growth in Māori population continues www.stats.govt.nz. Māori Art School Toi Hoikoura (Gisborne): http://www.eit.ac.nz/events/toihoukuras-annualta-moko-wananga/ (accessed 18 September 2018)

Aotearoa is not for sale: http://www.nznotforsale.org/ (accessed 11 October 2012)

Te Ati Awa Iwi: http://www.atiawa.com/marae_history.htm (accessed 25 February 2020)

High Commissioner for Human Rights: http:/www.ohchr.org (accessed 25 February 2020) Ministry for Culture and Heritage, musket wars overview: http://www.nzhistory.net.nz/war/musket-wars/overview. (accessed 14 January 2019) 
Whanganui museum: http://www.wrm.org.nz/index.php?page=staff \&contentid=3\&catid=1 (accessed 21 February 2019)

Treaty of Waitangi differences between the texts:

http://www.nzhistory.net.nz/politics/treaty/read-the-Treaty/differences-between-the-texts (accessed 8 April 2014)

Māori Art School Te Puia (Rotorua): http://www.tepuia.com/new-zealand/new-zealandmaori-arts-and-crafts/ (accessed 18 September 2018)

Montpellier University: http://www.collections.univ-montp2.fr/ in "les

collections/ethnologie". (accessed 25 July 2015)

Ngatu Toarangatira Iwi: http://www.ngatitoa.iwi.nz/ (accessed 16 May 2018)

Māori Women's Welfare League: http://www.mwwl.org.nz/maori-womens-welfare-leaguehistory/ (accessed 16 May 2018)

Rochette, M. Blog bnf (Bibliothèque Nationale de France) Pierre Marie Dumoutier, un phrénologue dans les mers du Sud. (accessed 5 June 2014)

Statistics New Zealand (2013). 2013 Census QuickStats about Māori, p. 13:

www.stats.govt.nz (accessed 12 November 2013)

Taonui, Rāwiri (2005) Canoe traditions, Te Ara - the Encyclopedia of New Zealand, http://www.TeAra.govt.nz/en/canoe-traditions (accessed 6 May 2020)

Taonui, Rāwiri (2011) Whakapapa- genealogy- What is Whakapapa?, Te Ara- the Encyclopedia of New Zealand, http://www.TeAra.govt.nz/en/whakapapa-genealogy/page-1 (accessed 15 November 2018) 
Tattooed applicant goes right off Air NZ, In: New Zealand Herald, 30 May, 2013.

http://www.nzherald.co.nz/nz/news/article.cfm?c_id=1\&objectid=10887232 (2 June 2013)

Te Puni Kokiri: www.tpk.govt.nz/eu (accessed 18 September 2018)

The Dominion Post, Te Papa to lose treasured Māori whare, In: Stuff.co.nz,

http://www.stuff.co.nz/dominion-post/news/5751912/Te-Papa-to-lose-treasured-Maori-whare, last updated 8 October, 2011 (accessed 10 December 2011)

Toi moko art print upsets, New Zealand Herald, 13 May, 2012.

http://www.nzherald.co.nz/nz/news/article.cfm?c_id=1\&objectid=10805464 (accessed 2 November 2012)

Tangihanga of Dame Te Atairangikaahu : www.youtube.com (accessed 13 November 2019)

Wilson, J.M, tā moko history: http://awanderingminstreli.tripod.com/tamoko.htm. (accessed 2 November 2012)

http://www.maori.cl/Proverbs.htm (accessed 23 March 2019)

NZ History, The discovery of New Zealand, Jules Sebastien Cesar Dumont d'Urville France 1790-1842, (accessed $16^{\text {th }}$ May 2018)

Youth not in employment, education, or training: September 2011 quarter (Revised 9

February 2012) http://www.stats.govt.nz/browse_for_stats/income-andwork/employment_and_unemployment/NEET-paper.aspx (accessed 2 November 2013)

Watters, S. (2015) Musket Wars, Ministry for Culture and Heritage website, URL: http://www.nzhistory.net.nz/war/musket-wars/overview. (accessed 4 March 2016)

\section{Tattooists' websites:}

Inia III \& Aileen Kemp (Auckland): http://www.mokoink.com (accessed 8 December 2012)

Henare Brooking (Lower Hutt): https://www.facebook.com/pages/Mokoira (accessed 8 December 2012)

Hohua Mohi (Rotorua): https://www.facebook.com/MOKO101 (accessed 8 December 2012)

Hohua Mohi (1st tattoo shop- Rotorua): www.kupapaink.com (accessed in June 2009)

Pip Hartley (Auckland): www.manamoko.co.nz (accessed 8 December 2012) 
Taryn Beri (Wellington): www.tarynberi.com (accessed 8 December 2012)

Mark Kopua (Porirua Bay): https://tamokoake.wordpress.com (accessed 8 December 2012)

\section{Artists' websites and biographies:}

Richard Nunns (taonga puoro): http://www.richardnunns.net.nz/ (accessed 16 October 2014)

James Webster (taonga puoro, tā moko artist): http://www.tahaa.co.nz/biography-mainmenu38.html (accessed 16 October 2014)

Horomona Horo (taonga puoro): http://www.horomonahoro.com (accessed 16 October 2014)

Brian Flintoff (taonga puoro): http://www.jadeandbone.co.nz/brian-flintoff (accessed 7 June 2012)

\section{Interviews}

Puawai Cairns, Museum of New Zealand Te Papa Tongarewa

22 March 2019

Arapata Hakiwai, Museum of New Zealand Te Papa Tongarewa

9 April 2019

Coralie O’Hara, Auckland War Memorial Museum

23 May 2019

Te Herekiekie Herewini, Karanga Aotearoa Repatriation Programme

28 May 2019

Catherine Morin-Desailly, Senator of Seine Maritime

19 July 2019

Roger Boulay, Anthropologist

4 September 2019

Sébastien Minchin, formerly Museum of Rouen

9 September 2019

Michel Van Praet, formerly ICOM France and MNHN

18 September 2019

\section{B. Secondary Sources: Books, book chapters, journal articles, theses etc.}

"Wahanga tuaiwa te Nama : E Iwa" (1994) In: Pipiwharauroa, vol.9 no.9, June 1994, p. 6.

Aldrich, R. (1989) “Le lobby colonial de l'Océanie française”. In: Dekker Paul de, and Toullelan Pierre-Yves. Revue française d'histoire d"outre-mer, tome 76, n²84-285, 3e et 4e trimestres 1989. La France et le Pacifique. pp. 143-156. 
Alivizatou, Marie. (2012) Intangible Heritage and the Museum: New perspectives on cultural preservation, Left Coast Press. Walnut Creek. California.

April, Sylvie \& Bensimon, Fabrice. (dir.) (2006) La France et l"Angleterre au XIXème siècle, Echanges, représentations, comparaisons, Creaphis, Paris.

Aranui, Amber. (2011) “Te Papa research into the early collection and trade of Toi moko", research file of the Karanga Aotearoa Repatriation Programme. Museum of New Zealand Te Papa Tongarewa, Wellington.

Aranui, Amber. (2018a) Te Hokinga Mai O Ngā Tüpuna: Māori Perspectives of Repatriation and the Scientific Research of Ancestral Remains. $\mathrm{PhD}$ thesis submitted to Victoria University of Wellington.

Aranui, Amber. (2018b) "Toi Moko in Toi Art: A Harbinger for a Conversation, The Pantograph Punch blog, November 22, 2018. https://www.pantograph-punch.com/post/toimoko-toi-art (accessed 23 November, 2018)

Aranui, Amber. (2020) “The Ethics and Repatriation and Working Collaboratively in Aotearoa New Zealand" (blog), February 2, 2020. https://boasblogs.org/de/humboldt/theethics-of-repatriation-and-working-collaboratively-in-aotearoa-new-zealand/ (accessed 7 February, 2020)

Atkinson, Jeannette. (2009) "Respecting and Preserving Cultural Values: Partnerships in New Zealand Museums", paper distributed at the conference Museum Curators and Communities: Embedded Approaches to Participation, Collaboration, Inclusion, Horniman Museum, London, 26-27 November 2009.

Babelon, Jean Pierre. \& Chastel, André. (1994) La notion de patrimoine, Liana Lévi, $3^{\text {rd }}$ edition, Paris.

Ballara, Angela. (2003) Taua: musket wars, land wars or tikanga? Warfare in Maori Society in the Early Nineteenth Century, Penguin, Auckland.

Bancel, Nicolas. Blanchard, Pascal. Boëtsch Gilles. Deroo Eric. \& Lemaire, Sandrine. (2004) Zoos humains, La Découverte Poche, Paris.

Banks, Joseph. (1962) The Endeavour Journal of Joseph Banks 1768-1771, vol. 2, Angus and Robertson Limited, Australia. 
Barlow, Cleve. (2001 (1991)) Tikanga Whakaaro: Key concepts in Māori Culture. Auckland. Oxford University Press.

Bayly-McCredie, Liliane (2016) Museum Diplomacy: Developing cultural partnerships between New Zealand and China. Master thesis submitted to Victoria University of Wellington.

Beaglehole, John Cawte. (ed.) (1962) The Endeavour Journal of Joseph Banks: 1768-1771. Trustees of the public Library of New South Wales in association with Angus and Robertson, Sydney.

Belich, James. (1986) The New Zealand Wars and the Victorian interpretation of racial conflict, Auckland University Press, Auckland.

Belich, James. (2001) Paradise Reforged: A History of the New Zealanders from the 1880s to the Year 2000, Allen Lane Penguin, Auckland.

Belich, James. (2006) Making People: A History of the New Zealanders: from Polynesian settlement until the end of the nineteenth century, Penguin Books, Auckland.

Bennett, George. (1831) The mode of preparing human heads among the new zealanders, with some observations on cannibalism, Journal of the Royal Institution of Great Britain, John Murray (ed), London, August 1831.

Bennett, Tony. (1995) The Birth of Museum: History, Theory and Politics, Routledge, London.

Bentley, Trevor. (1999) Pakeha Māori The extraordinary story of the Europeans who lived as Māori in early New Zealand, Penguin Books (NZ), Penguin Books (NZ) Ltd, Auckland 1310.

Bergeron, Yves. Rivet, Michèle. (ed.) (2021) The Decolonisation of Museology: Museums, Mixing, and Myths of Origin, ICOFOM, ICOM.

Best, Elsdon. (1900) "Spiritual concepts of the Māori”, The Journal of the Polynesian Society, Volume 9, No. 4, December 1900. 
Best, Elsdon. (1903) "Notes on the art of war as conducted by the Maori of New Zealand: Part VIII", The Journal of the Polynesian Society, Volume 12, No.4, December 1903, p. $193-$ 217.

Best, Elsdon. (1904) “The Uhi-Māori or native tattooing instruments", Journal of the Polynesian Society. Vol. 13, No. 3.

Best, Elsdon. (1924) "Traditional History and its teaching - The whare wananga, or school of learning", In: The Māori-volume 1, New Zealand Text Collections, Wellington.

Best, Elsdon. (1934) The Māori as he was: A Brief Account of Life as it Was in Pre-European Days, Dominion Museum, Wellington.

Best, Elsdon. (1941) The Mãori-Volume 2, The Polynesian Society, Wellington.

Best, Elsdon. (1972) “Tuhoe, The Children of the Mist”, $2^{\text {nd }}$ ed., Polynesian Society and A. H \& A. W Reed, Wellington.

Best, Elsdon. (1976) Māori Religion and Mythology, Part 1, Dominion Museum Bulletin No.10, A. R Shearer, Government Printer, Wellington.

Besterman, Tristam. (2006) "Museum Ethics", In: Macdonald, S. A companion to Museum Studies, Wiley-Blackwell, London, p .431-441.

Bienkowski, Piotr. (2015) “A critique of museum restitution and repatriation practices”, In: McCarthy, C. (ed), The international handbooks of Museum Studies : Museum Practice, First Edition, John Wiley \& Sons, Ltd.

Blais, Hélène. (2005) Voyages au Grand Océan, Géographies du Pacifique et colonisation, 1815-1845, coll. « Géographie », Paris : CTHS.

Blanchard, Pascal. Boëtsch, Gilles. \& Snoep, Nanette Jacomijn. (eds.) (2011) The Invention of the Savage: Human Zoos, Actes Sud, Musée du quay Branly, Paris.

Boulay, Roger. (2000) Kannibals and Vahinés, collection Carnet de voyage, éditions de l'aube, France.

Božić-Vrbančić, Senka, (2003) “One Nation, Two Peoples, Many Cultures: Exhibiting Identity at Te Papa Tongarewa” In Toon van Meijl and Michael Goldsmith (eds), In: 
Postcolonial Dilemmas: Reappraising Justice and Identity in New Zealand and Australia, a special issue of The Journal of the Polynesian Society 112 (3): 295-313.

Brown, Deidre S. (1996) “Te Hau ki Turanga”, The Journal of the Polynesian Society, Volume 105, p. 7-26.

Butts, David. (2002) “Māori and Museums: The Politics of Indigenous Recognition”, In: Sandell R. (ed.), Museums, Society and Inequality, Routledge, London, pp. 225-243

Butts, David. (2003) Mãori and Museums the politics of Indigenous recognition, $\mathrm{PhD}$ thesis submitted to Massey University, Palmerston North.

Butts, David. (2006) “Museum Governance, Indigenous Recognition and (In)Tolerant Multiculturalism”, New Zealand Sociology no.21(1), pp. 89-106.

Butts, David. (2007) "Māori, Museums and Treaty of Waitangi: The Changing Politics of Representation and Control” In: Knell, Simon. MacLeod, Suzanne. \& Watson, Sheila. Museum Revolutions: How Museums Change and are Changed, Routledge, London, pp. $215-227$.

Cadot, Laure. (2007) “Les restes humains : une gageure pour les musées ?”, La lettre de l’Ocim, n.109, Paris, pp. 4-15.

Cadot, Laure. (2009) En chair et en os : le cadavre au musée, Master's thesis submitted to Ecole du Louvre, Paris.

Cazaumayou, Sophie. (2007) Objets d'Océanie, regards sur le marché de l'Art primitif en France, l'Harmattan, Paris.

Charlier, Philippe. Huynh-Charlier, Isabelle. Brun, Luc. Champagnat, Julie. Laquay, Laetitia. \& Hervé, Christian. (2002) "Māori heads (mokomokai): the usefulness of a complete forensic analysis procedure", Forensic Science, Medicine, and Pathology, volume 10, number 2, 2014.

Clifford, James. (1997). Routes: Travel and Translation in the Late Twentieth Century, Cambridge, Mass.: Harvard University Press.

Cornu, Marie. (2006) Droit, auvres d"art et musées : Protection et valorisation des collections, CNRS editions. 
Cornu, Marie. (2009) “Le corps humain au musée, de la personne à la chose?” Recueil Dalloz, 30 Juillet 2009, n²8/7389, Editions Dalloz, Paris. pp. 1907-1914.

Cowan, James. (1911) The Adventures of Kimble Bent, Whitcombe and Tombs Ltd, Wellington.

Cowan, James. (1921) "Māori Tattooing Survivals—Some Notes on Moko", Journal of the Polynesian Society, Vol. 30, No. 4 (120), pp. 241-245.

Crenn, Gaëlle. Davidson, Lee. Gagné, Natacha. \& Roustan, Mélanie. (2014) "Pratiques muséales, politiques autochtones et travail des identités culturelles dans l'exposition itinérante « E tū Ake » (Nouvelle Zélande, France, Canada), 2011-2014”, Research Proposal-Final Report, April 2014.

Crooke, Elizabeth. (2008) "Museum and community: Ideas, issues and challenges", Routledge, London and New York.

Crooke, Elizabeth. (2015), “The 'Active Museum': How concern with community transformed the Museum", In: McCarthy, Conal. (ed), The international handbooks of Museum Studies : Museum Practice, First Edition, John Wiley \& Sons, Ltd.

Crosby, Ron.D (1999) “The Musket Wars, a history of inter-iwi conflict 1806-1845”, Reed Publishing, Auckland

Cummings, Milton. C. (2003) "Cultural Diplomacy and the United States Government: A Survey”. Washington, D.C.: Centre for Arts and Culture.

Davidson, Janet. M. (1984) The Prehistory of New Zealand, Longman Paul (ed.), Auckland.

Davidson, Lee. (2015) "Visitor studies: Towards a culture of reflective practice and critical museology for the visitor-centred museum”, In Conal McCarthy (ed.) Museum Practice. Volume 4 in the series International Handbooks of Museum Studies. General editors Sharon Macdonald and Helen Rees Leahy. Oxford and Malden, MA: Wiley Blackwell, pp. $503-527$.

Davies, Pier. (2002) “The return of Cultural Heritage to Indigenous peoples: Conflict or Cooperation?" 
De Bres, Joris. (2005) “Afterwords: The Evolution of an Inclusive National Identity”, In: Liu, James H. McCreanor, Tim. \& Mclintosh, Tracey. Teaiwa, Teresia. (eds.), New Zealand Identities. Departures and Destinations, Wellington, Victoria University Press, pp. 291292.

De Freycinet, Louis. (1837) Voyage autour du monde entrepris par ordre du Roi, Tome deuxième-troisième partie, Pillet aîné édition, Paris.

De l'Estoile, Benoit. (2008) “L’Anthropologie après les musées ?”, Ethnologie française nouvelle série, T. 38, No. 4, l’Europe et ses ethnologies, Octobre-Décembre, pp. 665-670.

De l'Estoile, Benoit. (2007a) Le goût des Autres. De l'exposition coloniales aux Arts premiers, Flammarion, collection la bibliothèque des Savoirs, Paris.

De l'Estoile, Benoit (2007b) “Du Musée de l'Homme au quai Branly : les transformations des musées des Autres en France”, Speech June 2006, Academia, (accessed 9 May, 2020)

Desvallées, André. \& Mairesse, François. (2010) Key Concepts of Museology, ICOM, Armand Colin, Paris.

Dias, Nélia. (2007) “Le musée du quai Branly : une généalogie”, Le débat, 147(5), pp .65-79.

Dieffenbach, Ernst. (1843) Travels in New Zealand with contributions to the geography, geology, botany, and natural history of that country, tome I, J. Murray (ed.), London.

Domeny De Rienzi, Louis.G (1856) Océanie ou cinquième partie du monde, tome troisième, Firmin Didot frères, Paris.

Donne, Thomas Edward. (1927) The Mãori, Past and Present: An Account of a highly Attractive, Intelligent People, their doubtful origin, Their customs and ways of living, Art, Methods of Warfare, Seeley Service, London.

Dr. Dulieu, Louis. (1961) “Joseph Marie Dubreuil Medecin Parisien, Chirurgien de la Marine et Professeur d'Anatomie à Montpellier', In : Revue d'histoire des sciences et de leurs applications, volume 14, pp. 33-46. Available online: http://www.persee.fr/web/revues/home/prescript/article/rhs_00487996_1961_num_14_1_3919 (accessed 14 April, 2015) 


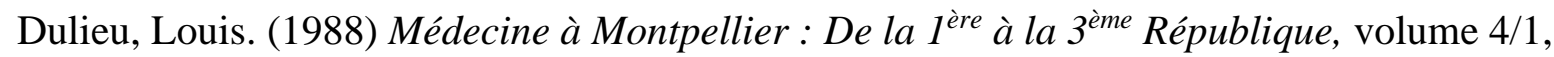
les Presses Universelles, Montpellier.

Dumont d"Urville, Jules Sébastien C. (1831) Voyage de la Corvette L'Astrolabe exécuté pendant les années 1826182718281829 Sous le Commandement de M. Jules DumontD’Urville, Capitaine de Vaisseau, tome deuxième, J. Tastu Editeur, Paris.

Dunbabin Thomas, (1923) “A Strange Trade: Deals in Māori Heads; Pioneer Artists”, Sydney Sun, 21 January.

Dunmore, John. (1965-1969) French Explorers in the Pacific, vols. 1 and 2, Clarendon Press, Oxford.

Dunmore, John. (1991) “Who’s who in Pacific Navigation”, University of Hawai'i Press, Honolulu.

Dunmore, John. (1992) The French and the Māori, Heritage Press, Waikanae.

Dupaigne, Bernard. (2006) Le scandale des arts premiers : La véritable histoire du musée quai Branly, Mille et Une Nuit, Paris.

Du petit-thouars, Aristide Aubert. (1841) Voyage au bout du monde sur la frégate «la Vénus » pendant les années 1836-1839, Tome 3, Gide Editeur, Paris.

Durie, Marie. (1998) Te Mana Te Kawanatanga: the politics of Māori self-determination, Oxford University Press, Auckland.

Ell, Gordon. Ell, Sarah. (2008) Explorers, Whalers \&Tattooed Sailors, Random House New Zealand, Auckland.

Elsmore, Bronwyn. (1999) Mana from heaven, a century of Māori prophets in New Zealand, Reed Books, Auckland.

Ferloni, Julia. (2006) De la Pérouse à Dumont d'Urville, les explorateurs français du Pacifique, éd. de Conti, Thalassa, Paris.

Fforde, Cressida. Hubert, Jane \&Turnbull, Paul. (2002) The Dead and their Possessions: Repatriation in Principle, Policy and Practice, vol. 43, Routledge, London. 
Film Festival Rochefort Conference, Restitution des restes humains. Table ronde du festival de cinéma Rochefort Pacifique. Journal de la Société des Océanistes, Octobre 2013.

Firth, Raymond. (1959) Economics of the New Zealand Māori, R. E. Owen, Wellington, $2^{\text {nd }}$ edition.

Fontanieu, Guillaume. (2014) “La question juridique des restes humains sous l'angle de la dignité de la personne", Les Annales des Droits, pp.197-227.

Fradier, Georges. (1979) “Editorial” In : Retour et restitution des Biens culturels, Revue de l’ICOM, vol. $31 \mathrm{~N}^{\circ} 1$.

Frobes, Steve. Hoult, Chris. (2012) New Zealand Tattoo in the home of the tattooist's art, libro international, China, 2012.

Gagné, Natacha. Roustan, Mélanie. (2014) “Accompagner les taonga à travers le monde : une exposition Māori à Paris et à Québec”, Note de recherche, Anthropologie et Société, vol.38, n॰3, pp. 79-93.

Gagné, Natacha. (2005) “Être jeune et Māori aujourd'hui : l'université comme site de (ré)affirmation et de coexistence”, Recherche amérindienne au Québec, vol. XXXV, n³, Québec, 2005.

Gagné, Natacha. (2012) “Affirmation et décolonisation : la cérémonie de rapatriement par la France des Toi moko à la Nouvelle-Zélande en perspective”, Journal de la Société des Océanistes, $\mathrm{n}^{\circ} 134$.

Gagné, Natacha. (2013a) "Un rapport ambigu à la ville? Les expériences des Māori d'Auckland', Les cahiers du Pacifique vol.7, L'Harmattan, Paris.

Gagné, Natacha. (2013b) Being Māori in the cities: Indigenous Everyday life in Auckland, University of Toronto Press, Toronto.

Gallagher, Sarah. K. J. (2003) ““A curious document’ Ta Moko as Evidence of Pre-European Textual Culture in New Zealand”, BSANZ Bulletin vol.27, n³ and 4.

Gallagher, Timoti. (2003) Tikanga Māori pre-1840, Te Kāhui Kura Māori, volume 0, issue 1, NZETC. 
Gathercole, Peter. (1990) “The Restitution of Heritage”, Anthropology Today, vol.6, n5, Royal Anthropology Institute of Great Britain and Ireland.

Genoways, Hugh. H. (ed) (2006) Museum Philosophy for the Twentyfirst Century, AltaMira Press, Oxford, UK.

Godelier, Maurice and Panoff, Michel. (ed.) (2009) Le corps humain, Conçu, supplicié, possédé, cannibalisé, CNRS éditions, Paris.

Goldie, W.H. (1904) “Transactions and Proceedings of the Royal Society of New Zealand 1869-1961", Article I, vol.37.

http://rsnz.natlib.govt.nz/image/rsnz_37/rsnz_37_00_0062_0036_ac_01.html (accessed 24 January, 2019).

Gordon, Ell. (1995) “Gold rush: tales and traditions of the New Zealand goldfields”, Bush, Auckland.

Grey, Georges. "manuscripts”, GNZMMSS 28 Auckland Public Library, In: Shirres, Michael P. (1982) Tapu, Journal of the Polynesian Society, volume 91, no 1.

Grincheva, Natalia. (2013) "Cultural Diplomacy 2.0: Challenges and Opportunities in Museum International Practices”, Museum and Societies, 11 (1), University of Leicester, pp. 39-49.

Guillot, Philippe Charles-André. (2006) Droit du Patrimoine Culturel et Naturel, ellipses, Paris.

Hackforth-Jones, Jocelyn. (1980) Augustus Earle Travel Artist, Rex Nan Kivell Collection National Library Australia, Canberra.

Hakiwai, Arapata (2014) He mana taonga, he mana tangata: Mãori taonga and the politics of Māori tribal identity and development, $\mathrm{PhD}$ thesis submitted to Victoria University of Wellington.

Hakiwai, Arapata. McCarthy, Conal \& Schorch, Philipp (2018) “The figure of the kaitiaki: learning from Maori curatorship past and present”, In Schorch and McCarthy (eds.) Curatopia: museums and the future of curatorship, Manchester University Press. 
Hamy, Ernest Theodore. (1918) "La collection anthropologique du muséum national d'histoire naturelle", L'Anthropologie, tome XVIII, n²1-2, pp. 257-276.

Hardwood, Hokimate P. (2014) “Ko Tïtokowaru: te poupou rangatira Tïtokowaru: a carved panel of the Taranaki leader", Tuhinga 25, Museum of New Zealand Te Papa Tongarewa, Te Papa Press, Wellington, pp. 16-24.

Harney, Elizabeth. (2006) “Les Arts Premiers in Paris: Le Monument De l'Autre.” African Arts 39(4), The MIT Press Journals, pp. 1-96

Hatfield, Gordon.Toi (Artist) Steur, Patricia (author) (2003) Dedicated by Blood: Renaissance of Ta Moko, Hunter, Auckland, 2003.

Herewini, Te Herekiekie \& Jones, June (2016) “A partnership approach to repatriation: building the bridge from both sides", Tuhinga 27: 1-9, Museum of New Zealand Te Papa Tongarewa, Wellington.

Higgins, Rawinia (2004) He tanga ngutu He Tūhoetanga Te Mana Motuhake o te Tã Moko Wāhine: The identity politics of Moko Kauae, $\mathrm{PhD}$ thesis submitted to the University of Otago.

Hīroa, Te Rangi. (Sir Peter Buck) (1949) The coming of the Māori, Māori Purposes Fund Board, Wellington.

Hole, Brian. (2007) "Playthings for the Foe: The Repatriation of Human Remains in New Zealand", Public Archaeology, vol.6 (1), W. S Maney \& Son Ltd, Wellington.

Horwood, Michelle. (2014) Worlds Apart: Indigenous Re-engagement with Museum-help Heritage: A New Zealand-United Kingdom Case Study, PhD Thesis submitted to Victoria University of Wellington.

Humboldt, Cuvier, Gay-Lussac, Arago, Desfontaines, de Rossel, Biot \& Thenard (1821) "Report made to the academy of Science upon the Voyage Round the World, in the Uranie commanded by M. de Freycinet", Treuttel and Wurtz, Jun and Richter, London.

Hunt, Tom. (2011) "French ignore Te Papa"s Toi moko plea”, Dominion Post, Wednesday 11 May, 2011. 
Isaac, Tuhoe. (2009) True Red the life of an ex-Mongrel Mob Gang Leader, True Red publication, New Zealand, Pukekohe.

Jean, Simon. (2010) L'opération de restitution de restes humains conservés dans nos collections muséales : l'exemple des têtes momifiées Māori, Master's thesis, submitted to Université de Rouen, Département Patrimoine : Aménagement et Gestion du patrimoine naturel et culturel.

Jean, Simon. (2013) “E Tū Ake: Māori Standing Strong/Māori: leurs trésors ont une âme, Te Papa, Wellington, and Musée du quai Branly, Paris”, Exhibit Reviews, In: McCarthy, Conal. (ed), Museum Worlds: Advances in Research, vol.1, Berghahn Books, New York and Oxford, p. 217-222.

Jean, Simon. (2019) "Reviewing Oceania: Océanie in Paris” In: McCarthy, Conal. Museum Worlds: Advances in Research, vol.7. Berghahn Books, New York and Oxford.

Johnstone, Karl. (2006) "Mātauranga and Museum Practice”, In: National Services Te Paerangi, He Raumi: Resource Guides Issue 31, Te Papa Press, Wellington.

Karp, Ivan. Steven, Lavine. (1991) "Exhibiting Cultures: The Poetics and Politics of Museum Display", Smithsonian Institution Press, Washington.

Keith, Hamish. (2001) "Core collections; Star in the United States, but out of sight at Te Papa", Sunday Star-Times, 11 November, 2001, p. 4.

Kendall, Thomas. \& Lee, Samuel. (1820) A grammar and Vocabulary of the language of New Zealand, London Missionary Society, London.

Kiendl, Anthony. (dir.) (2004) Obsession, Compulsion, Collection: On objects, Display Culture and Interpretation, Banff Centre Press, Alberta.

King, Michael. (1972) Moko Māori tattooing in the 20th century, Alister Taylor, Wellington, New Zealand

King, Michael. (1981) The collector: A biography of Andreas Reischek, Hodder and Stoughton, Auckland.

Knell, Simon. McLeod Suzanne \& Watson Sheila. (2007) "Museum Revolutions: How Museums Change and are Changed", Routledge, London and New York. 
Kreps, Christina. (1998) "Museum-making and Indigenous curation in Central Kalimantan, Indonesia", Museum Anthropology, 22 (1): 5-17.

Kreps, Christina. (2003) Liberating Culture: Cross-Cultural Perspectives on Museums, Curation, and Heritage Preservation, Routledge, London and New York.

Kreps, Christina. (2006) "Non-western Models of Museums and Curation in Cross-cultural perspective”, In: Macdonald, S. A companion to Museum Studies, Wiley-Blackwell, London, pp. 457-472.

Kreps, Christina. (2008) “Appropriate Museology in Theory and Practice”, Museum Management and Curatorship 23 (1), pp. 23-41.

Kreps, Christina. (2011) "Changing the Rules of the Road: Post-Colonialism and the New Ethics of Museum Anthropology”. In Marstine, Janet. (ed.) Routledge Companion to Museum Ethics: Redefining Museum Ethics in the 21st Century Museum, Routledge, London and New York.

Labourdette, Marie Christine (2015) Les musées de France, Presses Universitaires de France, Collection Que sais-je?, Paris.

Lane, Philippe. (2013) French Scientific and Cultural Diplomacy, University Press, Liverpool.

Laplace, Théodore. (1842) Campagne de Circumnavigation de la frégate l'Artémise, tome deuxième, Typographie de Firmin Didot Frères (ed.), Paris.

Laplace, Théodore (1853) Campagne de Circumnavigation de la frégate l'Artémise, tome cinquième, Typographie de Firmin Didot Frères (ed.), Paris.

Le Cam, Georges-Goulven. (1992) Mythe et stratégie identitaire; chez les Maoris de Nouvelle Zélande, L’Harmattan, Paris, 1992.

Le Louargant, Pauline. (2008) Statut juridique de la tête maorie du muséum de Rouen, Master thesis, Ecole du Louvre, Paris.

Lesson René Primevère et Garnot Pierre, “Zoologie”, Tome Premier, $1^{\text {re }}$ partie, In : Duperrey Louis Isidore, Voyage autour du monde sur la corvette de la Majesté, La Coquille, pendant les années 1822, 1823, 1824, et 1825, Arthus Bertrand, 1826. 
Lesson, René Primevère (1829) Voyage Médical autour du monde sur la corvette du roi La Coquille commandée par M. L. I Duperrey pendant les années 1822, 1823, 1824 et 1825, Librairie Roret, Paris.

Lesson, René Primevère (1838) Complément des æuvres de Buffon, tome II Races Humaines, Imprimeur J.Didot, Baudouin Frères, Paris.

Lesson, René Primevère. (1839) Voyage autour du monde entrepris par ordre du roi sur la Corvette La Coquille 1824-1826, Pourrat Frères éd, Paris.

Louisson, Simon. (1997) "Revival of tattooing tradition part of Māori renaissance”, Otago Daily Times, 16 June, 1997, p. 11.

Macdonald, Sharon. Fyfe, Gordon. (eds.) (1996) Theorizing Museums, Sociological Review Monographs. Oxford: Blackwell.

Macdonald, Sharon. (2006) A companion to Museum Studies, Wiley-Blackwell, London.

Maclean, Chris. (1999) Kapiti, Whitcombe Press, Wellingon.

Maguire, Marian. (2011) Titokowaru’s dilemma, Paper Graphica, Christchurch.

Mairesse, François. \& Desvallées, André. (ed.) (2007) Vers une redéfintion du musée?, Harmattan, collection Muséologies, Paris.

Makereti. (1986) The Old-time Māori, New Women's Press, Auckland.

Māmari, Stephens. (2001) A return to the Tohunga Suppression Act 1907, Victoria University of Wellington Law Review.

Mane-Wheoki, Jonathan. (1996) "Kohurangi/Toihoukoura: Brown Art in White Spaces", Art New Zealand, issue 78, pp. 43-47.

Maning, Frederick E. (1863) Old New Zealand, Whitcomb and Tombs, London.

Mauss, Marcel. (2010) Sociologie et anthropologie, Presse Universitaire Française, $12^{\mathrm{e}}$ édition, Paris.

McCarthy, Conal. (2007) Exhibiting Māori: a history of colonial cultures of display, Te Papa Press, Wellington. 
McCarthy, Conal. (2011) Museums and Māori: Heritage Professionals, Indigenous Collections, Current Practice, Te Papa Press, Wellington.

McCarthy, Conal. (2014) "The practice of repatriation: A case study from New Zealand," In Arvanitis, Kostos and Thythacott, Louise. (ed) Museums and Restitution: New practices, new approaches, Aldershot: Ashgate, pp. 71-83.

McCarthy, Conal. (2015) The international handbooks of Museum Studies: Museum Practice, vol.2, First Edition, John Wiley \& Sons, Ltd.

McCarthy, Conal. (2018) Te Papa: Reinventing New Zealand's national museum 1998-2018, Te Papa Press, Wellington.

McCarthy, Conal. Dorfman, Eric. Hakiwai, Arapata. \& Twomey, Awhina. (2015) "Mana Taonga: Connecting communities with New Zealand Museums through Ancestral Māori Culture”, Museum International, No.257-260, ICOM and Blackwell Publishing Ltd.

Mead, Hirini Moko. (1986) Magnificent Te Māori: Te Māori Whakahirahira: he korero whakanui I Te Māori, Heinemann, Auckland.

Mead, Hirini Moko. (2003) Tikanga Māori, living by Māori values, Huia Publishers, Wellington.

Mead, Hirini Moko. (2007) Te toi Whakairo, the Art of Māori Carving, Reed Publishing (NZ) Ltd, Auckland.

Mead, Hirini Moko. (2012) “Understanding Mātauranga Māori and Global Indigenous Knowledge”. In Haemata Ltd, Black Taiarahia, Bean, Daryn. Collings Waireka and Nuku Whitney (ed) Conversations On Mātauranga Māori, Wellington: New Zealand Qualifications Authority. pp.9-14.

Message, Kylie, McCarthy Conal (eds.), Museum Worlds: Advances in Research, Berghahn Books, New York.

Ministry for Culture and Heritage Te Manatū Taonga. (2004) "Repatriation of kōiwi tāngata Māori (Māori ancestral human remains)". Letter. Ministry for Culture and Heritage Te Manatū Taonga, Wellington. 
Moncan, Patrice. (1988) 'Le triomphe du VIIIe arrondissement”, SEESAM editions, gallica.bnf.fr (accessed May, 2012)

Monjaret, Anne. Roustan, Mélanie (2012), “Digestion patrimoniale”, Civilisations, 61(1), pp. $23-42$.

Morin, Hervé. (2012) “Quelle science pour les restes humains?”, Le Monde: Science et Techno, Saturday 21 January 2012.

Moudileno, Lydie. (2009) "Returning Remains: Saartjie Baartman, or the "Hottentot Venus" as Transnational Postcolonial Icon”, Forum for Modern Language Studies, Volume 45, Issue 2, 1 April 2009, pp. 200-212.

Murdoch, Riley. (1994) Māori Healing and Herbal: New Zealand Ethnobotanical Sourcebook, Viking Seven Seas, Paraparaumu, 1994.

Neich, Roger. (1979) "The Restitution and Return of Cultural Property-A New Zealand Viewpoint”, AGMANZ, News vol.10, N4: 5-10.

Neleman, Hans. (photographs), Wairere Iti, Tame. Turei, Pita. and McDonald, Nicole. (authors) (1999) Moko Māori tattoo, Stemmle, Zurich.

Nesus, Cath. (2004) "Making the Connection-Biculturalism at Work", Te Ara-journal of Museums Aotearoa 29, no.1, June 2004, pp. 12-15.

Ngata, Apirana T. (1972) Rauru-nui-ā-Toi lectures and Ngāti Kahungunu origin, Victoria University, Wellington.

Nisbett, Melissa. (2013) "New Perspectives on Instrumentalism: An empirical study of cultural diplomacy", International Journal of Cultural Policy. 19:5, pp. 557-575.

O’Halloran, Arthur. (1939) “Tragic French Expedition: Marion’s Voyage to New Zealand", The New Zealand Railways Magazine, Volume 14, Issue 2, Wellington.

O'Hara, Coralie. (2012) Repatriation in Practice: A Critical Analysis of the Repatriation of Human Remains in New Zealand Museums, Master's thesis submitted to Victoria University of Wellington.

O’Reagan, Hana. (2001) Ko Tahu, Ko Au, Tribal identity, Horomaka Publishing, Christchurch. 
O’Regan, Gerard. (1997) "Biculturalism, the Treaty and the spirit of partnership", New Zealand Museums Journal; v.26 no.2: pp.28-30.

Orange, Claudia. (2011) The Treaty of Waitangi, $2^{\text {nd }}$ edition, Bridget Williams Books, Wellington.

Paama-Pengelly, Julie. (2000) "Visible on our skin, close to our hearts", In: He kupu tiori / Toi Māori Aotearoa - Māori Arts New Zealand, no.4, October 2000, pp. 6-7.

Patin, Christelle. (2010a) “Exposer dignement les restes humains, hier et aujourd'hui. La mise en exposition publique de la Vénus Hottentote revisitée", Musée et collections publiques de France, numéro thématique Les "restes" humains dans les musées, 2010, n 159/2, pp. 413, Paris.

Patin, Christelle. Jean, Simon. (2010b) “La tête tatouée du muséum de Rouen : un patrimoine sensible à la croisée d"enjeux identitaires contemporains", distributed paper at the conference Patrimonialisations : enjeux identitaires et problématiques de développement, Ehess, Paris, 19 October.

Patin, Christelle. (2014) Les restes humains dans les musées. Anthropologie et histoire des collections françaises (XIXe-XXIe siècle), $\mathrm{PhD}$ thesis submitted to Ecole des Hautes Etudes en Sciences Sociales, Paris.

Peers, Laura. (2017) “The Magic of Bureaucracy: Repatriation as Ceremony”, In: McCarthy, Conal. Museum Worlds, 5(1), Berghahn books, New York, Oxford.

Peltier, Philippe and Mélandri, Magali. (2012) Chronologie concernant les têtes tatouées et momifiées māori ou toi moko (aussi connues sous le terme de moko mokai), Journal de la Société des Océanistes, 134, $1^{\mathrm{er}}$ semestre. URL : : http:// journals.openedition.org/jso/6638 ; DOI : 10.4000/jso.6638 (accessed 24 july 2016)

Petrie, Hazel. (2015) Outcasts of Gods? The struggle over the slavery in Māori New Zealand, Auckland University Press, Auckland.

Phillips, Lily. (2014), Là où dialgoguent les musées, Master's thesis submitted to Victoria University of Wellington.

Phillips, William John. (1948) "An introduction to the Study of the Tattooing chisels of the Māori with Notes on Tattoo", Dominion Museum records in ethnology vol.1, n³. 
Pickering, Michael. (2015) "Repatriation of Aboriginal and Torres Strait Islander Ancestral Remains by the National Museum of Australia”, In McCarthy, Conal. (ed.) The international handbooks of Museum Studies: Museum Practice, First Edition, John Wiley \& Sons, Ltd.

Picq, Pascal. (2012), "L’Affaire de la tête Maori-Tristes Tropismes”, Sud-Ouest journal, January 27 th.

Poata-Smith, Evan S. (2004) "Ka tika a Muri, Ka Tika a Mua? Māori protest politics and the Treaty of Waitangi Settlement Process", In: Spoonley, Paul, McPherson, Cluny and Pearson, David, Tangata tangata: The changing Ethnic Contours of New Zealand, Thomson/Dunmore Press, Nelson, pp. 59-88.

Poirier, Nicolas. (2003) Les baleiniers français en Nouvelle Zélande, les indes savantes, Paris.

Poisson, Jean-Frédéric. (2003) Bioéthique, éthique et humanisme : les lois de 1994, Bordeaux, Les Etudes Hospitalières.

Poulot, Dominique. (2001) Patrimoine et Musées, l'institution de la culture, Hachette, Carré Histoire, Paris.

Pourcelet, Francois (1994) Galéga (1827-1839) Poivre, Descroches, Saint Joseph, 1842-1851: Mémoires d'Auguste Le Duc, planteur de l'Océan Indien, Université de Provence, Aix en provence.

Preece, Kate. (2009) “Tribal tattoos, Blood lines”, Avenues, no.62, June 2009, pp. 26-30, Christchurch.

Price, Sally. (2007) Paris Primitive: Jacques Chirac's Museum on the Quai Branly, Chicago University Press, Chicago.

Price, Sally. (2013) "The Enduring Power of Primitivism: Showcasing the "Other" in $21^{\text {st }}$ century France", In Salami, G. and Blackmun Visona, M. A companion of African Arts, John Wiley and Sons, Chichester.

Proust de la Gironière, Muriel. (2002) La France en Nouvelle Zélande, 1840-1846 : Un vaudeville colonial, Le gerfaut édition, Paris.

Proust, Marcel. (1923) Remembrance of Things Past, La prisonnière, 5th Volume, Paris. 
Renneville, Marc. (2000) Le langage des crânes, une histoire de la phrénologie, Paris, Institution d'édition Sanofi-Synthélabo.

Rev. Walsh, Philip. (1894) "Māori preserved heads", The Transactions and Proceedings of the New Zealand Institute, Volume 27, Article LXX, 1 October 1894.

Robley, Horatio Gordon. (2003) Māori Tattooing, Dover Publication. Inc, Mineola, New York. $1^{\text {st }}$ ed. 1896

Roth, Henry Ling. (1901) "Māori tatu and moko", Journal of the Anthropological Institute of Great Britain and Ireland, vol 31, pp. 29-64.

Roustan, Mélanie. (2016) “Des usages de l'autochtonie dans les musées français”, Culture \& Musées, 28, pp. 151-175.

Royal, Te Ahukaramū Charles (2007) Mātauranga Māori and Museum practice, a discussion, Report for the National Services Te Paerangi, Museum of New Zealand Te Papa Tongarewa, Wellington.

Royal, Te Ahukaramū Charles (n.da) "Kaitiakitanga-guardianship and conservation, Kaitiaki - guardians", Te Ara - the Encyclopedia of New Zealand, updated 22 September 2012, (accessed 15 April, 2014).

Royal, Te Ahukaramū Charles (n.d) "Papatūānuku — the land, whakapapa and kaupapa, Te Ara - the Encyclopedia of New Zealand”. www.teara.govt.nz, (accessed February 2011).

Salat-Baroux, Frédéric. (1998) Les lois de la bioéthique, Collection Dalloz Service, Paris.

Salmond, Anne. (1997) Between Worlds: Early Exchanges between Maori and Europeans, 1773-1815, Viking/Penguin, Auckland.

Salmond, Anne. (2004) The trial of the cannibal dog: Captain Cook in the South Seas, Penguin Books, Auckland.

Saou-Dufrêne, Bernadette N. and Djenidi, Amel (2018) "Musées, colonialisme, indépendance : figures du donateur”, Perspective Le Maghreb, INHA, 153-172.

Schorch, Philipp (2010) Te Papa: a forum for the world? A narrative exploration of a global public sphere, $\mathrm{PhD}$ thesis submitted to Victoria University of Wellington. 
Schorch, Philipp. McCarthy, Conal (2018) Curatopia: Museums and the future of curatorship, Manchester University Press.

Schubert-McArthur, Tanja. (2014) Walking the Talk? An Ethnography of Biculturalism at Te Papa, PhD thesis submitted to Victoria University of Wellington. (published in Routledge edition in 2019)

Sciascia, Ana. (2012) Iwi Exhibitions at Te Papa: a Ngāi Tahu perspective, Master's thesis submitted to Victoria University of Wellington.

Shannon, Jennifer (ed.). (2017) "Ritual Processes of Repatriation A discussion". In Museum Worlds vol.5, Berghahn Books, New York, Oxford.

Shirres, Michael P. (1982) “Tapu”, Journal of the Polynesian Society, vol. 91, pp. 29-52.

Simmons, David R. (1986) Ta Moko the art of Māori Tattoo, Reed Methuen, Auckland.

Simpson, Moira G. (1996) Making representations: Museums in the Post-colonial Era, Routledge, London and New York.

Simpson, Moira G. (2007) "From Treasure House to Museum... and Back”, In: Watson, Sheila. (ed.), Museums and Their communities, Routledge, London and New York.

Sinsoilliez, Robert. (2005) L'expédition des Normands en Nouvelle Zélande. Charles Corlet Editions, Condé-sur-Noireau.

Sir Kingi Ihaka. (1989) "Biculturalism and Museums from a Māori point of view”, AGMANZ News, vol 22, $\mathrm{N}^{\circ} 2,1989$.

Smith, Huhana. (2006) “The Museum of New Zealand Te Papa Tongarewa”, In: Healy, Chris. Witcomb, Andréa. South Pacific Museums-Experiments in Culture, Monash University ePress, Melbourne.

Smith, Huhana. (2011) E tu Ake Māori standing strong, exhibition catalogue, Te Papa Press, Wellington.

Smith, Laurajane. (2004) “The repatriation of human remains; problem or opportunity?" Antiquity, volume 78, Issue 300. 
Smith, Linda Tuhiwai (2012) Decolonizing Methodologies: Research and Indigenous Peoples, zed book ltd, second edition, London and New York.

Smith, Stevenson Percy. (1910) Māori wars of the Nineteenth Century, Whitcombe and Tombs, Christchurch.

Stack, James West. (1906) “The Sacking of Kaiapoi”, In: Travers, William Thomas Locke. The stirring Times of Te Rauparaha, Whitcombe \& Tombs, Christchurch.

Stefani, Claude. (2010) "Pierre Adolphe Lesson un acteur et témoin méconnu de l'exploration du Pacifique dans la première moitié du XIXe siècle". http://lesson.odsas.net/ecrits/Stefani_Claude.pdf (accessed 24 May, 2013)

Sutton, Douglas G. (1993) The Archaeology of the Peripheral Pa at Pouerua, Northland, New Zealand, Auckland University Press.

Sylvester, Christine. (2009) Art/ Museums: International Relations Where We Least Expect It. London: Paradigm Publishers.

Tamarapa, Awhina. (dir.) (2011) Whatu kākahu-Living Cloaks, catalogue exhibition, Wellington, Te Papa Press.

Tapsell, Paul. (2002a) "Marae and Tribal identity in Urban Aotearoa/New Zealand", Pacific studies 25, Nos 1 and 2, March/June, 2002.

Tapsell, Paul. (2002b) "Partnership in Museums: A tribal response to Repatriation", In: Cressida Fforde, Jane Hubert and Paul Turnbull (ed), The Dead and their Possessions: Repatriation in Principle, Policy and Practice, London: Routledge.

Tapsell, Paul. (2003). “Beyond the Frame: An Afterword”. In: Peers, Laura and Brown, Alison K. (eds). Museums and Source Communities: A Routledge Reader, 242-251, Routledge, London \& New York.

Tapsell, Paul. (2011a) "Aroha Mai: Whose Museum? The rise of Indigenous ethics within museum contexts: A Māori-tribal perspective”, In: Marstine, J. (ed.) Routledge Companion to Museum Ethics: Redefining Ethics for the Twenty-First Century Museum, Routledge, London. 
Tapsell, Paul. (2011b) The Art of Taonga, Victoria University, Essay, School of Art History, Classics and Religious Studies, January 2011.

Tapsell, Paul. (2013) Ko Tawa: Māori treasures of New Zealand, David Bateman Ltd, Auckland.

Tapsell, Paul. (2014) "Māori and museums—ngā whare taonga: Te Māori and its impact”, Te Ara - the Encyclopedia of New Zealand. (accessed 2 February,2017).

Tauroa, Hiwi and Tauroa, Pat. (1986) Te Marae: A Guide to Customs and Protocol, Reed Methuen, Auckland.

Taylor, Richard. (1855) Te Ika a Maui. Wertheim and MacIntosh, London.

Te Awekotuku, Ngahuia. (2002) “Tā moko: Culture, body modification, and the psychology of identity", the proceedings of the National Māori Graduates of Psychology Symposium 2002.

Te Awekotuku, Ngahuia, Nikora, Linda Waimarie \& Rua, Mohi Robert (2003) "In your face: wearing Moko-Māori facial marking in today’s world", Tatau/Tattoo: Embodied art and cultural exchange Conference, 21-23 Aug 2003.

Te Awekotuku, Ngahuia. (2004) "He maimai aroha: A disgusting Traffic for Collectors: The colonial Trade in Preserved Human Heads in Aotearoa", In: Kiendl Anthony (dir.), Obsession, Compulsion, Collection: On objects, Display Culture and Interpretation, Banff Centre Press, Alberta.

Te Awekotuku, Ngahuia. (2007) Mau Moko, The world of Māori Tattoo, Penguin, Rosedale.

Te Rangikaheke, Wiremu Marsh. (1986) “A minute description by a New Zealand chief of all the ceremonies observed on the occasion of tattooing a chief and of the mode of performing the entire operation [He pukapuka whakaatukorero kia te kuini]", Sir George Grey N.Z. Māori MS. 89, David Roy Simmons, Auckland Public Library.

Te Ara-The Encyclopedia of New Zealand (2008) Māori Tribes of New Zealand, David Bateman, Auckland.

The Treaty Of Waitangi. (2017). The Treaty Of Waitangi. https://nzhistory.govt.nz/ (accessed 12 April, 2012). 
Thomas, Nicholas. (1991) Entangled Objects: Exchange, Material Culture, and Colonialism in the Pacific, Cambridge, MA: Harvard University Press.

Thomas, Nicholas. Adams, Julie. Lythberg, Billie. Nuku, Maia and Salmond, Amiria (2010) Artefacts of Encounter Cook's Voyages, Colonial Collecting and Museum Histories. Otago University Press.

Thomas, Nicholas. (2016) The Return of Curiosity: What Museums are Good For in the Twenty-first Century, Reaktion Books, United Kingdom.

Tourancheau, Philippe (2011) “The Fabulous Story of a Mummified Maori Head of Rouen Museum”, via Decouvertes Production \& France 3 Haute-Normandie, $52 \mathrm{~min}$.

Tremewan, Peter. (1990) French Akaroa, University of Canterbury Press, Christchurch.

Turnbull, Paul. (2017) Science, Museums and Collecting the Indigenous Dead in Colonial Australia, Palgrave in Pacific Studies, Palgrave Macmillan, Springer International Publishing, Switzerland.

Tythacott, Louise and Arvanitis, Kostas (ed). (2014) Museums and Restitution: New Practices, New Approaches, Ashgate Publishing Ltd.

Varea, Sébastien, Larson, Christelle and Minchin, Sébastien. (2011) 'La fabuleuse histoire de la Tête de Maori de Rouen et sa numérisation, Lasergrammétrie”, Revue XYZ, n $127-2 \mathrm{e}$ trimestre 2011, pp. 29-32.

Van Praët, Michel. (2013) "Saartje Baartman, une restitution témoin d'un contexte muséal en évolution. La Vénus Hottentote entre Barnum et Museum.” In : Blanckaert, Claude (dir.), Collection archives, Publications Scientifiques, MNHN, pp. 367-385.

Wakefield, William. (1839) “Journal”, 27 September, Alexander Turnbull Library, Wellington.

Walker, Ranginui. (2004) Ka whaiwhai Tonu Matou-A struggle without end, Penguin books, revised edition, New Zealand.

Walker, Taingunguru Whangapirita. (2013) Ngā Pā Harakeke o Ngati Porou: a lived experience of whānau, $\mathrm{PhD}$ thesis submitted to Victoria University, Wellington. 
Walkin, Timoti. (1997) "Facing the past: The ancient art of ta moko has been getting a new lease of life, but who should wear them?", The Listener, 17 May 1997.

Watson, Sheila. (ed.) (2007) Museums and their communities, Routledge, London.

Wilkes, Annette. (2013) Between People and Things: Understanding violence and theft in early New Zealand Transactions, $\mathrm{PhD}$ thesis submitted to the University of Canterbury, Christchurch.

Williams, Herbert, William (1957) A Dictionary of the Māori Language, $6^{\text {th }}$ edition, Government Printer, Wellington.

Williams, Paul. (2005) "A Breach on the beach: Te Papa and the fraying of biculturalism", Museum and Society 3 (2), pp .81-97.

Wolfe, Richard. (2005) Hell-hole of the Pacific, Penguin Books, New Zealand. 